Distribution Categ

Magnetic Fusion Er

(UC-20)

ANL/FPP/TM-127

\author{
ARGONNE NATIONAL LABORATORY \\ 9700 South Cass Avenue \\ Argonne, Illinols 60439
}

\title{
RECENT CONTRIBUTIONS TO FUSION REACTOR DESIGN AND TECHNOLOGY DEVELOPMENT
}

Fusion Power Program

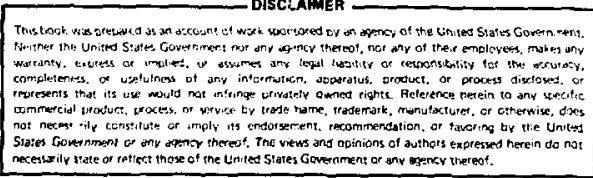

November 1979 


\section{LIST OF PAPERS}

1. STARFIRE - A Commercial Tokamak Reactor

Page

C. C. Baker, M. A. Abdou, D. A. DeFreece, C. A. Trachse1,

D. Graumann and J. Kokoszenski ............

2. Reoults of Systems Studies for the STARFIRE Comercial

Tokamak

M. A. Abdou, D. A. Ehst and L. M. Waganer. ....... T

3. The Impurity Control System for the STARFIRE Commercial

Fusion Reactor

J. N. Brooks, C. C. Baker, H. C. Stevens

and C. A. Trachsel ...............

4. Assessment of Solid Breeding Blanket Options for Commercial Tokamak Reactors

D. L. Smith, R. G. Clemmer and J. W. Davis ...... 16

5. First Wall and Blanket Design for the STARFIRE Commerclal Tokamak Power Reactor

G. D. Morgan, C. A. Trachsel, B. A. Cramer, D. A. Bowers

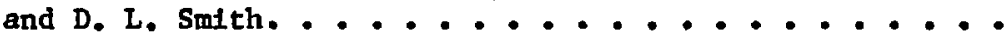

6. Tritium Handling and Vacuum Considerations for the STARFIRE Commerclal Tokamak Reactor

P. A. Finn, R. G. Clemmer, V. A. Maroni and C. Dillow. .

7. Superconducting Pololdal Colls for "STARFIRE" Commercial Reactor

S.-T. Wang, K. Evans, Jr., L. R. Turner, Y.-C. Huang,

R. Prater and J. Alcorn..............

8. Toroidal Field Coll System for "STARFIRE", A Prelininary Assessment

J. S. Alcorn, S.-T. Wang and L. R, Turner. .......

9. Maintenance Considerations of the STARFIRE Conmerclal Tokamak

C. A. Trachse1, H. S. Zahn, R. E. Field and H. C. Stevens.

10. Fusion Reactor Technology Impact of Alternate Fusion Fuels

C. C. Baker, A. Bolon, R. Clemner, K. Evans, Jr.,

J. Jung, D. Smith, L. Turner, T. Blue, J. DeVeaux,

D. Driemeyer, J. Metzger, G. MIley and W. Tetley .....

11. Shielding and Maintainability In an Experimental Tokamak

M. A. Abdou, G. Fuller, E. R. Hager and

W. F. Vogelsang. .................

12. Safety of Superconducting Fuston Magnets: Twelve Problem Areas 
LIST OF PAPERS continued

13. Overcurrent Protection for the TFTR Neutral Beam Sources Du: Ing Spark Down

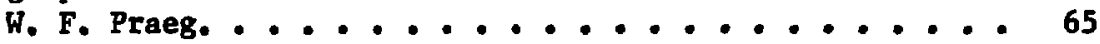

14. Resistivity, Hysteresis, and Magnetization of $9 \% \mathrm{Cr}$ Stainless

Steel as a Function of Temperature and Its Electromagnetic

Shielding Effects in Cylindrical Structures

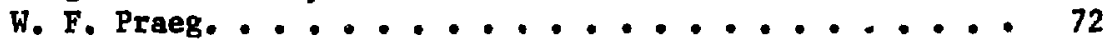

15. Development of a $50 \mathrm{kA}$ Cryostable AC Superconducting Cable

S. H, KIm and $S,-T$. Wang ............ 78

16. General Phase-Frequency Shifting in the Three-Phase InductorConverter Bridge

M. Ehsani, R. L. Kustom, R. E. Fuja and

T. J. Barnard. ................ 80 


\section{FOREWORD}

The report contains a collection of recent fusion technology papers on the STARFIRE Project, the study of alternate fusion fuel cycles, a maintainability study, magnet safety, neutral beam power aupplites and pulsed super:conducting magnets and energy transfer.

This collection of papers contains contributions for Argonne National Laboratory, McDonnel1 Douglas Astronautics Company, General Atomic Company, The Ralph M. Parsons Company, the Untversity of Illinols and the University of Wisconsin. 
STARTEE - A COARECIAL IOKAMAK RBACTORH

\author{
C. C. Baker, M. A. Abdou \\ Argona bational Laburatory \\ Arpoune, Illinolo 60439 \\ D. A. DaFreece, C. A. Trachael \\ MeDonmell Dougles Astronautica Coupany \\ St. Loule, M1seour1 63166 \\ D. Graunann \\ General Atoolc Coopany \\ San D1e80, Cal1fornia 92138 \\ J. Tokoszenaki \\ The Ralph M. Parsons Company \\ Paeadena, California 91124
}

\section{Introduction}

The bastc objective of the STARFIRE Project ${ }^{1}$ is to develop a design concept fer a comercial tokmak funton electric power plant based on the deuteriun/ trittud/1thiun fuel cycle. The key technical obfecE1ve 1o to develop the best embodiment of the cokamaik a a power reactor consistent with credible engineerIns molutions to design problems. Another key goal of the profect is to give careiul attention to the safety and environgental features of a cownercial funton reector.

The basic dealgn guldelines for STARFIRE ansune the succeseful operation of tokamk engineering test facility (ETP) and a demontration pover plant. STARIRe is convidered to be the tenth planc in a seriee of comercial ractorw. It 1s, therefore, assumed that a well establitohed vendor industry exista and that utilities have gainos experience with the operation of fualon plants.

The STARFIRE Project 1 was Initlated in My, 1979. with the goal of completing the design otudy by Oetober, 1980. The purpose of this paper 1a to preeent an overvies of the major parameters and design fatures that have been tentatively selected for sTARTIRE. Several papers presented in this conference provlde nore detalls on the deatgn charecterinetics of key renctor components.

\section{Eafor Parameters}

A prienry goal of the STARIRE atudy 10 to atelect the wort attractive set of design parameters and concepts that anke tokemake econonically conpetitive and eavironentally acceptable. Remult provided by and experfence galned from previous fuston renctor deIm studies in the United States and worlduide have provided an excellent starting point for this profect. In addition, extensiva trade-off studies ${ }^{2}$ vere performed to aupport tha design selection procese for stavine.

IIgure 1 show a crose section of the reactor. A sumary of the enfor reactor parameters end design fantures in given in Table 1. The reactor therasl power is $23800 \mathrm{kH}$ and the ret electricel power is $21150 \mathrm{~km}$. Thle powar level is expected to be in the most desirable range of power rating to the utilitied in the STARFIns tine frame.

Wort supported by the U.S. Depertenent of Ineres.
The neutron wall load $183.5 \mathrm{~mW} / \mathrm{m}^{2}$. Baged on reaults fron detalled system studles, this moderately high wall land is a reasonable choice that results in a sall size reactor without excessive requirements on the first-wall cooling capability, maximum toroidal magnetic field and frequency of structural material replacenent.

A D-ahned plasan with a helght-to-width ratio of 1.6 has been selected. This was found to be nearly the highest elongation that is consistent with the STARFIRE goal of locating almost all the equilfbriunf1eld (F) colle outside the toroldal-field (MF) colla.

W1th an aspect ratio of 3.6 the major radius 18 $7 \mathrm{n}$. The average plasma torolaal beta $1 \mathrm{~s} 0.067$ and the eacian toroidal magnetic field in $11 \mathrm{I}$.

\section{Operating Mode}

stendy-atate has been selected as the mode of operation for STARFIRE. Although experimental informetion on planan current drive by means other than inductive of colla are very limited, result from receat theoretical atudies juatify the assumption that continuous plasine burn can be achieved in the STARFIRE tise freme.

The potential advantages of steady-state reactor operation Include: (a) increased composent and syiten reliabllity, (b) alininnting fatigue as a serlous concern for the structural makerial in the first wall and blanket, (c) no thermal enurgy storege is required and the need for an intermediate coolant loop it reduced, and (d) no electrical energy utorage in necegsary.

\section{Plecen Engineering}

The besic plaswa parameters of the STARFIRE deol gn are linted in Table 2. Lowar hybrid wavea const1tute the reference plasm current driver due to the ore developed theoretical understending of this option. Other wave drive candidates coneldered include relativiatic lactron beaso and matretosonic vaves.

The ratio of fusion power to if power (Q) required to mintain the atendy-atete toroldal current of a toknak is linfted by the plane's accessibility to lorer hybrid vaves. In particular, low denntey planere are more easily penetrated and reault in higher Q then high deneity plasen. This is the repson thet, for a fliced $B_{t}$, relatively high temperaturee end low denalties are attractive for STARFIR. Bowever, for $T>15 \mathrm{keV}$ the fuston power denelty decrenses so quickif that relatively high magnetlc fialde are accessery 


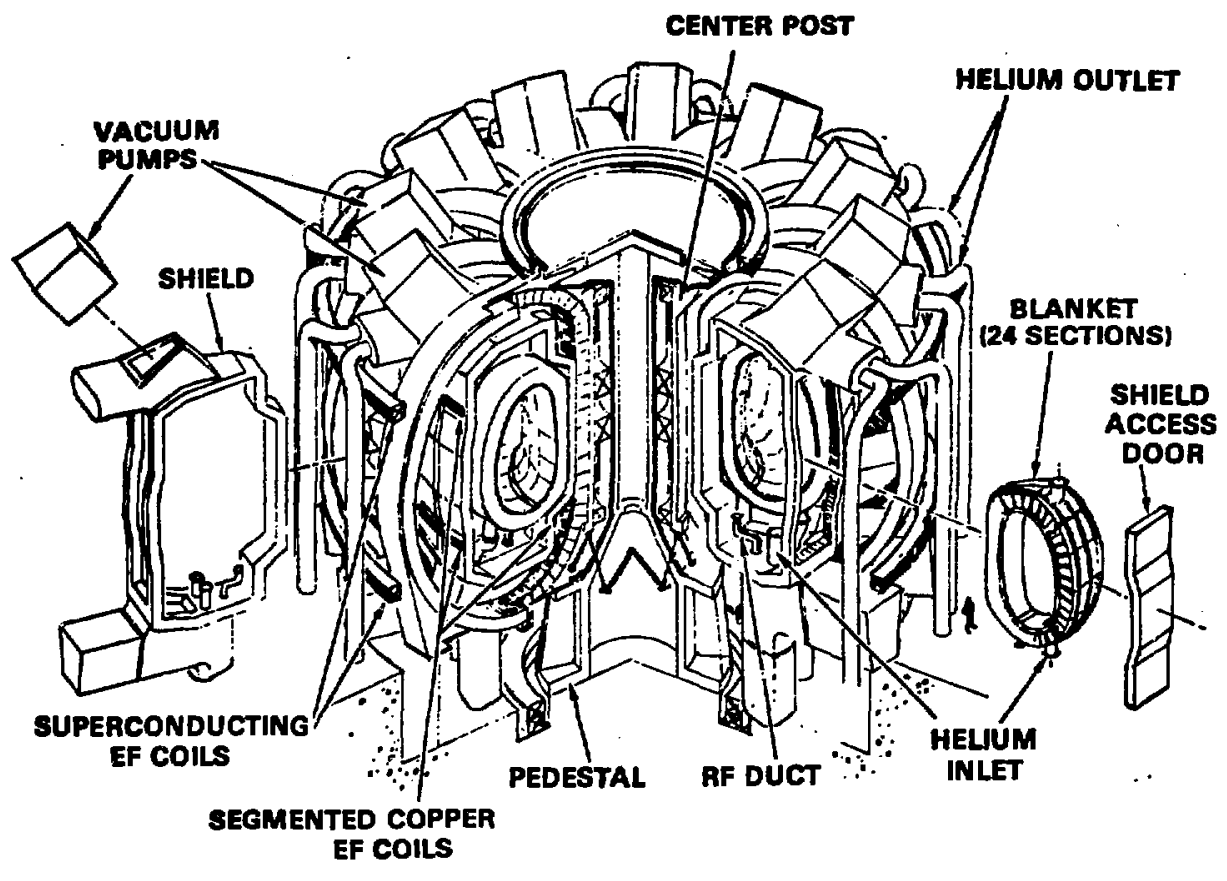

71g. 1. STARPTRE reference denign.

Iable 1. STARFIRE Major Design Features

Table 2. STARFIRE P1ane Paremeters

\begin{tabular}{|c|c|}
\hline Iet electrical power & $1150 \mathrm{sH}$ \\
\hline Grose electrical power & $1600 \mathrm{HA}$ \\
\hline Pusion power & $3200 \mathrm{kH}$ \\
\hline Therenel power (nomina1) & 3800 \\
\hline Thernodynanic efficiency & $41 x$ \\
\hline Oyerall avatlability & 758 \\
\hline Arerage neutron vell load & $3.5 \mathrm{p} / \mathrm{H} / \mathrm{m}^{2}$ \\
\hline Najor radiue & 7.0 \\
\hline Plage half-ardith & $1 ; 94=$ \\
\hline P1egen elongation $(b / a)$ & 1.6 \\
\hline Ynx, toroldal fleld (noetinal) & $11.0 \mathrm{~T}$ \\
\hline Nunbar of $\mathrm{TP}$ cotls & 12 \\
\hline Placena burn wode & Continuous \\
\hline Current drive wethod & If \\
\hline place heatins wethod & It \\
\hline II coile meterinl & $\mathrm{mb}_{\mathrm{g}} 3 \mathrm{n} / \mathrm{h} \mathrm{GI} / \mathrm{Cu} / \mathrm{ss}$ \\
\hline wall atructural meteriel & Perritic eteel \\
\hline Dlanket atructural =terial & Ferritic stenl \\
\hline trall coolant & $\mathbf{D}_{2} \mathrm{O}$ \\
\hline Tritiun breedins andiu & $\mathbf{w}_{2} \mathrm{O}$ \\
\hline plasiket coolent & Eelive \\
\hline tracen Impurtty contrell & 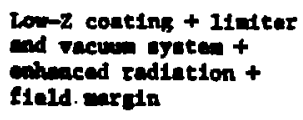 \\
\hline ixtery vacuu boundary & At Inoser adpe of shield \\
\hline
\end{tabular}

Minjor radius

Plame half width

Elongation $(b / a)$

P1asera ehape

Average toroldal beta

P1ase current

Safety factor (center)

Safety factor at edge

Toroldal fleld on axt.

Average Dr Ion denity

Average electron density

Averege Ion temperatura

Average electron teparature

Fractional Inpurfty conceatration

Fractionnl alphe concentration

Fractional burmup

$$
\begin{aligned}
& x-7= \\
& \text { a }-1.94= \\
& x=1.6 \\
& \text { "Dn } \\
& 8_{t}=0.067 \\
& I=11 \mathrm{M} \\
& q_{0}=1.4 \\
& q_{a}=4.2 \\
& \mathrm{v}_{\text {to }}=5.62 \mathrm{~T} \\
& \overline{\overline{D T}_{\mathrm{T}}}=1.0 \times 10^{20} \mathrm{~m}^{-3} \\
& \bar{a}-1.3 \times 10^{20} \mathrm{~m}^{-3} \\
& \overline{I_{1}}=17 \mathrm{kr} \\
& \overline{T_{e}}-22 \operatorname{kev} \\
& \mathrm{T}_{\mathrm{B}} / \mathrm{hr}=0 . \mathrm{GH} \\
& n_{d} / n_{D r}=0.09 \\
& \text { f }-0.11
\end{aligned}
$$


to keap the resctor else attractively ma11. A related otrates to mudinize $Q$ 10 to drive the highent current deneltied were the planan denelty 10 low, 1.e.. near the plasene surface. Particuler attention wat be given in this cane to the rot atebility of ouch current denelty profllas.

of the two candidate if sources, croused-field anpliflers (CFA) and kiystrond, the forner way pronine to operace at higher efficiencies $(70-90 \pi)$. but, due to the large anounts of power diselpated in the $\mathrm{rf}$ structure, the CFA option ay incresse the engineering difficulties. The tranamision line is enviatoned to be a high pover preseurfzed waveguide with a power splittiag labyrinth to provide the grill phane shifts. The syate will be denigned with the ECR layer in the high pressure region; the vacuum yindow will be placed out of the direct line-of-sight of neutron radiation. Phese ehifters will be included to provide opectral turalng for the reactor atartup period.

Our balc approach for impurity control is to use a wates with fairly low resoval efficiency, n 30\%. This ie sufficient to maintain a stable operating point, whle at the same tice reducing the asount of purped tritiun.

The reference system chosen is a Iindter/vacuuru syate which together serves to concentrate and purp sowe of the plasme particle outflux. In addition, the TF fleld coll to designed with enough field angin to contaln the sxcasa pressure of the alpha particles and electrons. There are two other basic features of the 1epurfty control systen; low $Z$ costinge are used on 11 exposed surfaces; and the plasma is operated wo a to maxiatze the heat radiated from it and to ainiaze the transported heat. This approach, therefore, results in four techniques working in unison. These are: (a) low-Z costings, (b) magnetic field wargin, (c) eahenced radiation, and (d) 11niter/vacuun system.

\section{F1ret/Wall glenket}

The technological and dealgn aspactu of various first-wall/blarket concepta have been conoldered in the eelection of potentially viable dasigne for STARPTRE. The major emphasis has been placad on the developrent of a blanket design that is safe and crovironmentelly acceptable. The primary guidelines establishad to meet these criteria are low tritium Inventory in the blanicet, minimal long-1ived activation products and ainimal stored chemical energy.
A comprehenolve esucsenent of potential tritiue braeding materiale, coolente and atructural meteriala was carried out. The scope of assessment included meter1al properties, neutronicu, compatibility and operating teeperature lintations, generic afety apecte and tritiu recovery methods. Baed on the reoult of this asesement, the nost viable combinationa of breeder/coolant/structural material/neutron mitiplier are given in Table 3. The reference blanket oyoten 1a aelected on the basis of percelved safety advantagen aseociated with hellun coolant and the solid breeding anterials. Hellur is selected only for the blanket coolant since water provides several advantages an the firat-wall coolant. The ceramic breeding materials with their high temereture properties are most approprlate for the hellum coolant. Lithiun oxide is proposed as the breeding material since it is the only ceramic with potential for breeding wthout a neutron witiplier. The ferritic steels are compatible with both helium and water coolant and are selected for both first-wall and blanket-structure. A low pressure helium purge strean over the $\mathrm{LI}_{2} \mathrm{O}$ 1s used for tritium processing siace direct contace of high presaure heliun coolent and $\mathrm{LI}_{2} \mathrm{O}$ is not acceptable.

Since the thermal-hydraulic characterietics of preaeurized water are superior to those of hellum in temperature-1imited systems, an alternate first-wall/ blanket materials option is proposed. The alternate concept utilizes $D_{2} \mathrm{O}$ coolant in both the first wall and the blanket. Lithium oxide is retalned es the breeding waterial and ferritic ateel as the firatvall/blanket structure.

Ilquid 11thium, which can be ued as both coolnnt and breeder, providea a unique blanket option. However, the Inherent-safety of this system has been queationed and maintenance-related problems have been Identified. An Interwedlate coolant loop may also be desirable. However, jecause the thermal-hydraulics, neutronics, radiation behavior, and design simplicity of this aystem are generally regarded as auperior to other blanket materials option, this aysten is suggeatad an a backup. The backup design will be considered if Irresolvable technical or engineering problew are Identified in the early phase of the project for the raference and alternate dealgns. Selected vanadium alloys, which are proposed for the structural meterial, are believed to be the wot resistant to radiation dawage of the cendidate structural materials,

Table 3. Selected F1rat-Hall/Blonket Materiele Options

\begin{tabular}{|c|c|c|c|c|c|c|}
\hline \multirow[b]{2}{*}{ Coolent } & \multicolumn{3}{|c|}{ Coolent } & \multicolumn{2}{|c|}{ Structure ${ }^{*}$} & \multirow{2}{*}{$\begin{array}{c}\text { Neutron } \\
\text { Mule1plier }\end{array}$} \\
\hline & $\boldsymbol{N}$ & Blanket & Breader & $\mathbf{F}$ & Blenket & \\
\hline Doference & $\mathrm{D}_{2} \mathrm{O}$ & He & $\mathbf{L}_{\mathbf{2}} \mathbf{O}$ & Fs & Fs & $\mathrm{PbO}^{* \hbar}$ \\
\hline Alternate & $\mathrm{D}_{2} \mathrm{O}$ & $D_{2} \mathrm{O}$ & $\mathbf{L 1}_{2} \mathrm{O}$ & Is & $\mathbf{F s}$ & $P b 0^{* *}$ \\
\hline Backup & L1 & LI & 21 & $\nabla$ & $\nabla$ & $\mathbf{m}^{*+k}$ \\
\hline
\end{tabular}

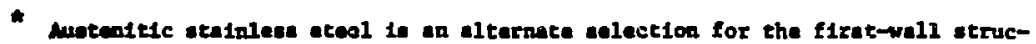
ture and both austenteic ateinless eteel and titantum alloge are possible altarnatives for the blanint atructure.

4.

If raguired.

whet zequired. 
produce low long-tere activation products, are compat1ble with 11thlum, and possase adequate elevated teporature mechanical proparties. Lang blanket 11fetie wy be attainable ance the 11quid lithlua is not censitive to radiation damage and tritiun-release from the 1iquid also does not present a problen.

No wechanical design concepte are being con-1dered for the referenca blanket. In the first concapt, the oodule walls are preseurized to the coolant tratic pressure. The solld breeder is held in sealed tubas, arranged in a stapgered rod bank patcern, which are cooled by cross-flouing the helfum over them. In the second concept, the helium coolant flows Inside tubes each of which is surrounded by solid breeder throughout the module. In both concepts, the tritfum produced in the solid breeder is removed continuously through a hellum purge gas system. The two concepts will be compared in the near future after further evaluation to determine which is supertor from an overall reactor design standpoint.

\section{Heat Transport System}

Tha tharal energy deposited in the blanket and Hiret vall is delivered via the heat transport syatem to the power conversion system there electricticy is generated. The heat transport and power cycle systems conalat of the primary hellum (blanket coolant) loops, primary water (firat wall and nonbreeding reglona coolant) loops, auxillary cooling loopa, and the team/power converaion ayatem as shown schemacically In F1g. 2.

W1th the water-cooled f1rat wall and inboard blanket, approximately 40 percent of the thermal anergy is in the form of $300^{\circ} \mathrm{C}$ heat. This energy 1s utllized in the power converaton aystem for feedyater heating and for steam generation. The remalning 60 percent of the thermal energy la tranaported via the hellum blanket coolant to the atean generators. The prianry loope consiat therefore of both hellue and water clrcults.

Decaune STARTIRE operated steady-atate rather than in a pul eed mode, a theral energy atorage syatem 1s not required. Furtheruire, no internediate coolant loop is provided and the heliun loop interfaces directly with the stean generator. The consequences of stean ingress into the hallum loop were prevlously addressed for the high-temperature gas cooled reactor (HTGR). It was found that adequate anfoguards againat stent inleakage can be provided. A calculation of permeation losses from the hellum coolant through the steam generator was performed. It has been concluded that, due to the fact that the tritlum is predoninantiy in the oxidized form, and due to the falrly low temperature, tritium permeation losses will be very anall and an intermediate coolant loop is not required.

\section{Vecuum Pumping Syatem}

The primary vacuum boundary of the STARFIRE vacuum syatem 1s at the Inner wall of the shield. A pair of $\approx 60$ meter long toroidal 11miters pasa cireumferentially around the outer edge of the plasm region, and deflect lons from the acrape-off zone into the adjacent slots in the firat wall. A cross-sectional view of these slots 1s shown in Fig. 3. The - lots are 60 meterg long and $20 \mathrm{~cm}$ wide and penetrate the firat wall and blanket. The location and conflguration of the limiter 1. optigized to maximize the probability of a molecule entering the slot after striking the 1imiter. Each mlot contains a step to reduce neutron streaming as shown in Fig. 3. In the molecular flow region this step has ainimal effects on the conductance, the only consideration being the additional lot length required to provide the step. A large volume plenum exists between the outalde of the

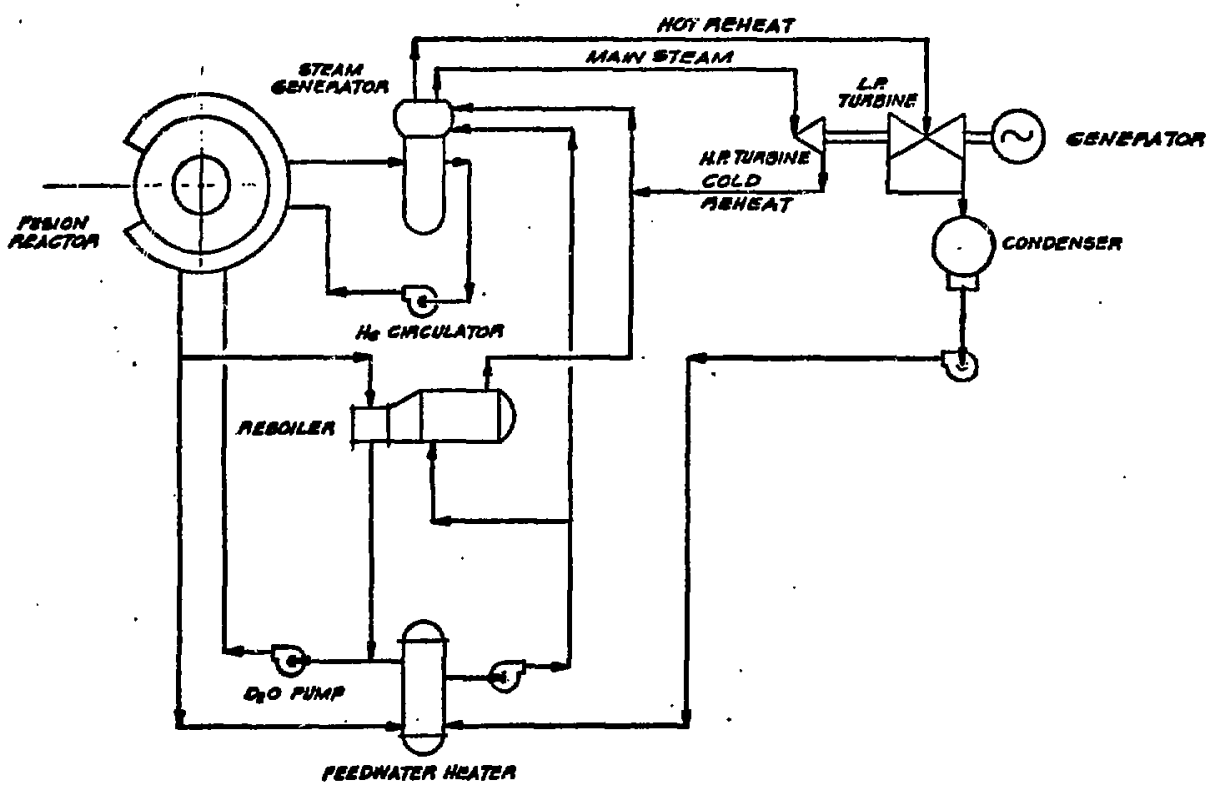

118. 2. Power conversion ayoten schematic. 

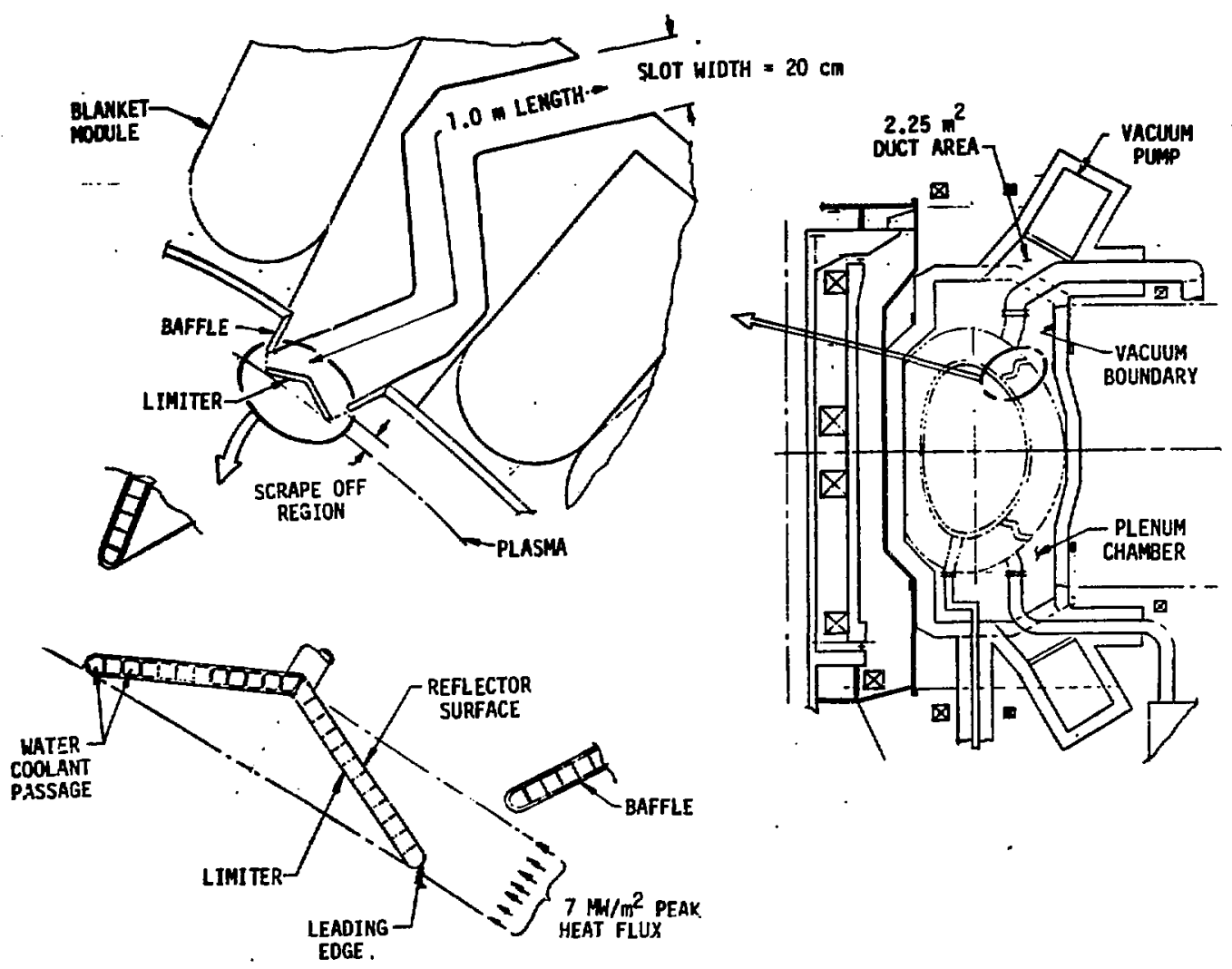

F1g. 3. Linfter/vacuun duct concept.

firat wall blanket and the Inside of the shield. Iwenty-four 1.7 meter diameter. 1.5 meter long vacuum duct. penetrate the shield and provide access for 11quid hellum cryogenic pumpa.

The 1iquid helfum cryogentc pumps will be of the corpound variety in which hydrogen and its isotopes are purped by cryocondensation on a 11quid hellum cooled panel and helfun is cryosorbed on a $4.2^{\circ} \mathrm{K}$ molecular - leve surfaca. The cryosorption aurface on such a punp can become saturated with hellum and will require regeparation after approximately elght hours of operat1on. Regeneration wll be accomplished by atopping the 11quid helium flow and allowing the sorption surface to wars whereupon the helium is released and punped away by another pumping aystea.

\section{Other Engineering Features}

The reactor magnet ayatem design Includes twelve 11 Teela TF colla. The EP coll aysten Includes 4 aeganted coppar coile inalde the Tr coila for plasma atab1l1ty control, but wost of the EF colla are superconducting and located outelde the TP coliv for plasue equilibriun. The plasma startup, hoating and current drive 1s accomplished by a lower lybrid if gyoten. The ahiald incorporatea dielectric breaka to prevant toroldel current flow and pernit the EF colls that are located Inalde the TF coll to have adaquate raponsa tian for planar atability control.

The reactor ohield is designed for I1femol-plent and 10 sot rewoved for normel entntenance operations.
The shield concept is shown In Fig. 4. The reactor shield Is water cooled and serves as the primary vacuum chamber. The shield protrudes between the TF colls at the top and bottom of the reactor to provide vacuun duct to 24 cryosorption pumps. The vacuum duct opening through the shield is oversized to permit routing of coolent lines through the openIng without significantly restricting pumping capacity. Each helium coolant line is ohielded at the penetration through the shield by a bed of roda in a staggered pattern that limits neutron leakage. The shield contains pololdal dielectric breaks under every third TF coll. The dielectric jolnt, which is at the outside of the ohield and completes the vacuun barrier, is exposed to about $10^{10}$ rads irradiation. The dielectric break will also be redundant and Incorporate intermediate purping. The shield piecea are destgned to keep all geal welds betwaen shield pieces in a engle plane rithout walded cornera, In order to improve reliabllity and aluplify the intallation operation. The shield doors utilize redundant Bura-k aeals to provide the vacuum bartier. The seals are located near the outalde of the shield; however, degradation by expoaure to tritiun and neutrons is expected to reault in the need for ceal replecentent anch time the coor io rewovad during arintenanca.

The ef vove gulded form a near contizuous toroldal ring at tha baae of tha raactor. Approxinetely $100 \mathrm{M}$ of if porner 1s required to start and drive the plasen. The power density at the plapa $108 \mathrm{mit} / \mathrm{m}^{2}$. A wechenical rf varegulde connector 1s required to pernit blankat rewoval. 


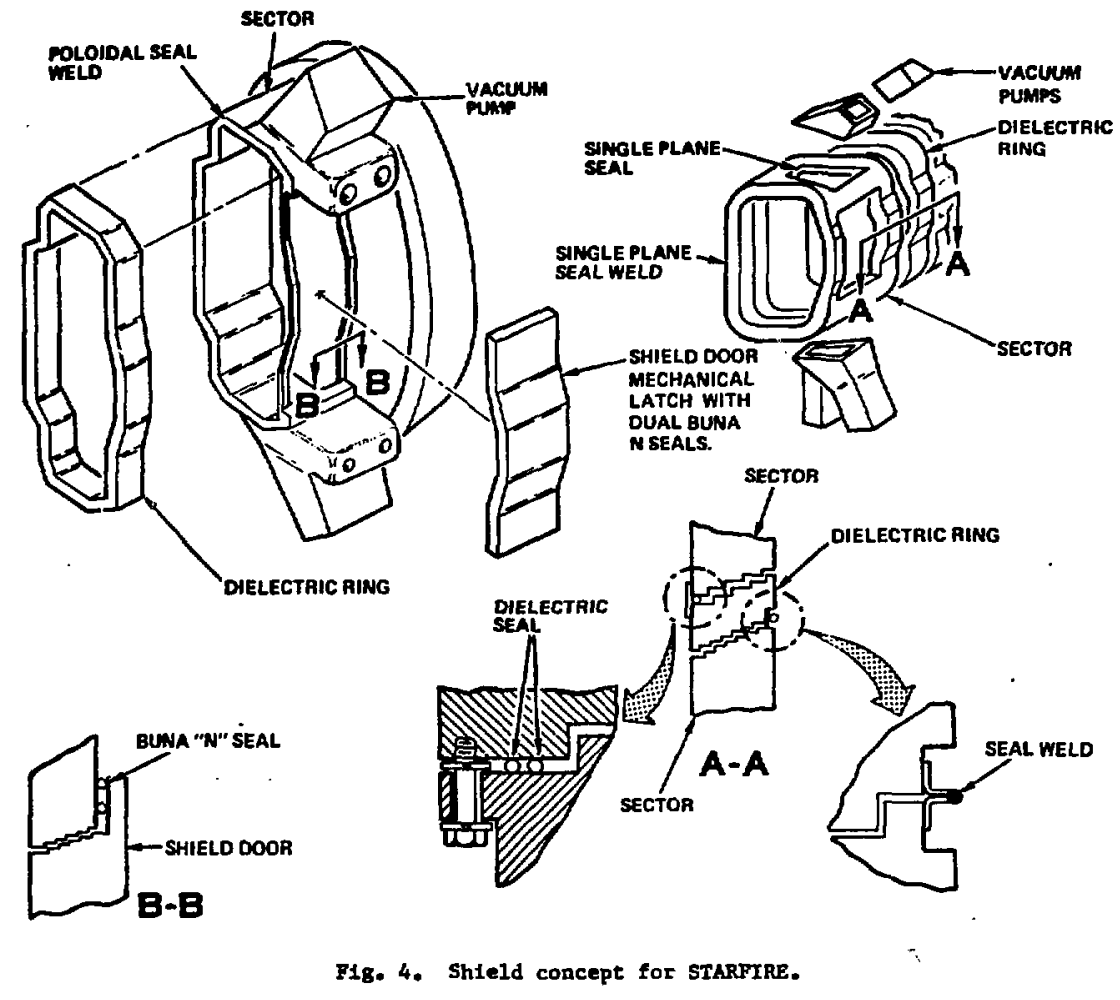

The blanket syatem is divided into 24 wdege ohaped aectors to obtain a size that permits removal of sectors between TF colls. Each blanket sector Incorporates an if waveguide, two limiter sepmente, and two stepped toroldal slots $20 \mathrm{~cm}$ wide for vacuum purping. Each sector is mounted on an alr bearing pad to permit removal and replacement.

The reactor bullding is metal ilned to provide - boundary against tritium release to the atmosphere. Acsess doors are provided to the Interfor through alrlocks to permit Ingress of reactor components, Continuous cleanup of the reactor bullding alr environneat is provided. The bullding is degigned for a maxiwo overpressure of 3 psi which could result from an eceldent in which the ilquid hellum from one TF coll and the coolant from one first wall/blanket sector are relensed Into the building.

\section{Maintenance Approsch}

Ava1lab1lity goals have been established to 857 for the reactor and $75 z$ for the complete plant including the reactor. There goals provide a basis for design of maintenance equipment. The antenance ecenar 1o Incorporates the current uellity practice of whutting down ammally for one wonth and a four wonth whutdow approxirately every 5-10 years.

The deatgn philosophy being followed to to mint1ze the radintion levels within the reactor building; to design ell components for complete remote ineintenance, and to Identify contect wintenunce operation there perwonnel can eefely be uned with olenifficant econonic savings.
The number of different maintenance operations planned in the reactor bullding are minimized by uaing a component "remove and replace" spproach. This permits each maintenance action to be preplanned and deaigned for use with simple push, puli, etc., operations. This approach Increases the confidence in the sped of maintenance operations and simplifies maintenance equipment design requirements. Once the damaged or end-of-11fe components are removed from the resctor they are transported to a hot cell where more tivie 1s avallable for checkout, repalr or disposal.

Redundancy. is planned for reactor auxiliary subsystems to permit continued operation of the plant unt11 scheduled meintenance period or unt11 the component can be replaced in-service. More detalls on the maintenance plan for STARFIRE are given in another paper in chis session.

\section{Acknouledgement.}

The authors of th10 paper are the profect anengers of the varlous orgenization involved in STARFIRE and thue represent many individual contributors. Theae Individual contributors are liated in the varfous companion pepera preaented at thit neeting.

\section{Refarancen}

1. "STARTIRE - A Comierc1al Tokenak Reector", (un Intarin report), Argonne National Laboratory Hebonnell Dougles Atronautice Conpany, General Atonle Company, and The Ralph M. Parcona Eempany (Oetober, 1979). 
RESULTS OF SYSTEHS STUDIES FOR THE STARFIRE COMERCIAL TOKAMAK"

\author{
M. A. Abdou and D. A. Ehat \\ Argonne Nactonal Laboratory \\ Argonne, Illinols 60439 \\ L. M. Waganer \\ MeDonnell Douglas Astronauc ics Company \\ St. Lou1s, MAssour1 63166
}

\section{$\underline{\text { Sumary }}$}

Extensive system and tradeoff studies were performed to support the selection process for the wajor parameters and design features of the STARFIRE comperclal reactor. With a thermal power of $3800 \mathrm{MH}$, a neutron wall lodd of $3.5 \mathrm{MW} / \mathrm{m}^{2}$ results in a relatively small-size reactor without lmposing excesalve requirements on the first-wall cooling capability, maximum toroidal-magnetic field, and frequency of structural material requirements. This moderately high-wall load requires that the first-wall coolant be 11quid (water or 1ithium) and the lifetime of the structural material is $315 \mathrm{iW}-\mathrm{yr} / \mathrm{m}^{2}$. With moderate plasma elongation and beta the required maximum coroidal-field is a.11 T. STARFIRE is operated steady-state with no OH coil. The atsence of an ot coil makes it possible to design the reactor w1th a low-aspect ratio $(22.5)$ and small major sad1us. However, h1gher aspect ratlos (23.5 4) are favored when the plasma current is driven with $\mathrm{rf}$ becauge the power required for the current drive, $P_{r f}$, is much larger at lower aspect ratto. Since $P_{r f}$ Increases at lower plasma temperature, the optimum design for STARFIRE requires operation with plasma temoratures higher than those normally selected for de: ' 328 with OH-driven current.

\section{Introduction}

Previous fugion reactor design and systems studies have demonstrated the presence of a wide range of design parameters and a diversity of design concepts. A primary goal of the STARFIRE study' is to select, based on present knowledge, the most attractive set of design parameters and concepts that make tokamaks economically competitive and environmentally acceptable. In addition to experience gained from dea1ga and systems studies in the United States and vorldwide, extensive tradeoff analyses were carried out to guide the selection process for STARFIRE. A primary tool for these tradeoff studies is a comprehensive systems corputer program that is capable of predicting the performance characteristics and economics of the entire tolcamak power plant. The ANL Systems Code $^{2}$ supplemented by the SDAC Code ${ }^{3}$ was utilized for this purpose.

The major design parameters that chracterize a tokamak reactor are the reactor power, the neutron wall load, aspect rat10, plasma longation, fojor radius, plasma beta, megaetic fleld, scrape-off region thickaess, and biankat/shield thickness. A briaf raview of the considerations that were factored 1nto relection of these major parametera 18 preseated in this paper.

\section{Reactor Poner}

It has been shown that tokanuk reactore exh1bit an aconoury of acale; 1.a. larger power ranctora hava lower cont of energy. However, three considerations imortant to the ut1lities 11mit the desirable power rating of a plant. The firat 10 the difficulty of ralsing the capltal for largar power plants. The

Work supported by the U. S. Departwent of Energy. second relates to the cost of reserve electric power capac1ty that the ut1lity mist provide to compensate for scheduled and unscheduled outages. The cost of reserve capacicy increases with the olze of the individual power plant. The third is the maximum capactity of a single turbine generator. Based on recoumendatlons by the Utility Advisory Committee for STARFIRE, the mogt desirable power rating at present is in the range of 3000-4000 $\mathrm{wW}$ for theraal power and $21250 \mathrm{wN}$ for electrical power. Therefore, the fuston power for STARFIRE was selected as $3200 \mathrm{kA}$. Th1s corresponds to a nol. Inal thermal power of $23800 \mathrm{kw}$, based on a $21-\mathrm{MeV}$ per fusion reaction, and a net electric power of 21150 MW. The recoverable thermal power will be modified by the addition of if power for current drive and the loss of low-temperature heat such as that in the lintter systen.

\section{Neutron Wall Load and Structure Life}

A key parameter that has a substantial 1mpact on the physical size of the reactor is the neutron wall load. The neutron wall load, $P_{n w}$, is related to the fuslon power, $P_{f}$, as

$$
P_{E}=P_{n v} A_{v}\left(\frac{17.6}{14.1}\right)=P_{P} V .
$$

where $A_{w}$ is the surface area of the first wall, $P_{P}$ is the average fusion power density in the plasma, and $v$ is the plasma volume. Por the arme $P_{f}$, higher $P_{n w}$ regules in a snaller surface area, h1gher power density, smaller reactor volume, and potentlally lower cost. This underlines the motivation for developing deafga with higher wall loads. Figure 1 shows the reiationship between the major radius and the neutron wall load Eor $P_{f}=3200 \mathrm{WN}$ and plasma elongation of 1.6 .

There are linttations, however, on both the ability to produce and the abllity to use high-wall loads. The upper lintes on the use of high-wall loads are dictated primarily by the first-wall cooling capability and the structure lifetime. Conatralats sucb as the naximin operating temperature and thermal atresses place an upper bound on the allowable wall lond. For typical structural materials wuch as ferritic steele in pulaed reactor systems, the neution wall load should be linited to $22.5 \mathrm{w} / \mathrm{m}^{2}$ for belium coolant. Higher wall loads are possible with water and 11thium coolants. In generif, the maxtmun allowable wall load is highar for reactore such as STARIRE operating in a steady-atate mode.

For a given fluence lifet1es, the neutron well load should be linited so that the frequancy of atructure replacanant is not excenslve. In order to linlt the fract Ionel increase in the cont of energy due to the plant downtime for raplacement of the structural naterial to $\delta$, the atructure 11fetime aut be oufficlently long to satiafy the following Inequality:"

$$
t_{w}>\frac{t_{d}}{365 \delta},
$$




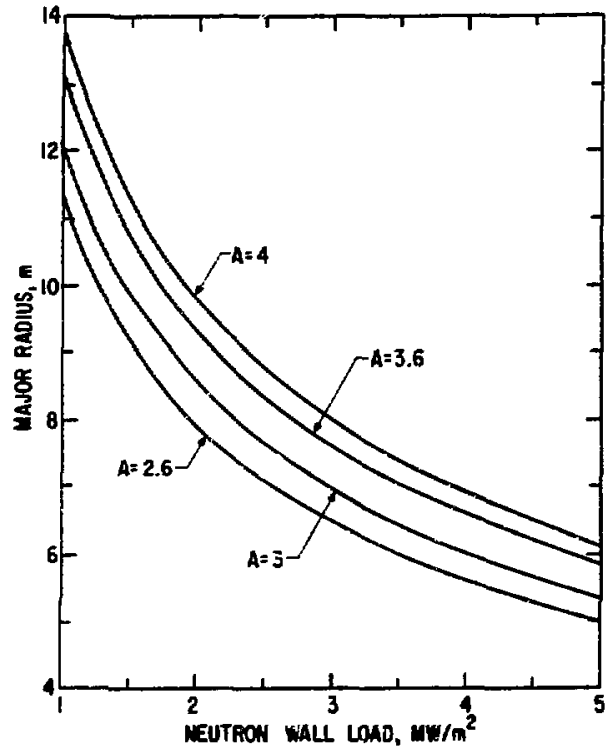

FIB. 1. Mafor radius as a function of neutron wali 1 lond at four values of the aspect ratio. Results based on: fusion power $=3200 \mathrm{w}$ and plasma elongation $=1.6$.

where $c_{q}$ is the structure lifetime in years and $t_{d}$ is the total cumilative downties in days for replacement of the structural material. For example, in order to linit the Increase in the cost of energy to $10 \mathrm{z}$ (1.e. $\delta=0.1$ ) when the downtine is 125 days the structure I1fetine must be greater than $3.4 \mathrm{yr}$.

For a given structural material and fluence I1fetime, the iges of energy production resulting from choosing $h \mathrm{hgh}_{\mathrm{gu}}$ and short $c_{\mathrm{y}}$ wat be weighed against the econonic gain realized by dentgning a sulil olze reactor. Figure 2 bows the cost of energy as a function of the neutron wall load at two values of the integral neutron wall load, $I_{w}$, of 5 and $20 \mathrm{~m}-\mathrm{yr} / \mathrm{m}^{2}$ and at two different values for the total cumlative down$t i m e, t_{d}$, for replacement of the structural materiol. For $I^{\prime}$ " $5 \mathrm{ythr} / \mathrm{m}^{2}$ and downt ine of 125 daye the neutron wall load hould be kept in the range of 2-2.5 $\mathrm{MW} / \mathrm{m}^{2}$. For $\mathrm{I}_{\mathrm{L}} 220 \mathrm{MH}-\mathrm{yr} / \mathrm{m}^{2}$ the cout of energy decresses ionificantly as the neutron wall lond is increased from 1 to $2 \mathrm{~km} / \mathrm{m}^{2}$. A smller, but significant, caving in the coat of energy (COE) is realizable by increasing $P_{\text {from }} 2$ to $3 \mathrm{kw} / \mathrm{m}^{2}$. A elight change in $\mathrm{COE}$ 10 noticeabio in the range $P_{n w}{ }^{2} 3-4 \mathrm{~s} / / \mathrm{m}^{2}$. The reasons for the modent increase in $\operatorname{COE}$ is $\mathrm{P}_{\mathrm{pu}}$ is Increased beyond $24 \mathrm{~h} / \mathrm{n}^{2}$ will becose evident from discusstons later in this paper.

It 1s clear from Fig. 2 that the achievable 11fetim of the etructural aterial has a elonificant 1 pact on the cost of enersy. By allainating short

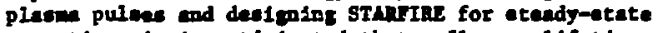
operation. It ie acticipeted thet a flunes lifotime of $20 \mathrm{sw}-\mathrm{yr} / \mathrm{m}^{2}$ or granter is obtaluable with selected condidate etructural mater1als. There are sevaral iportant adventares for such lons life: (a) the cont of enerey 1o ubetantialiy reduced because of leas frequent replacesent and hipher avallability factor; and (b) when the frequency of raplacenent is mubstantialiy

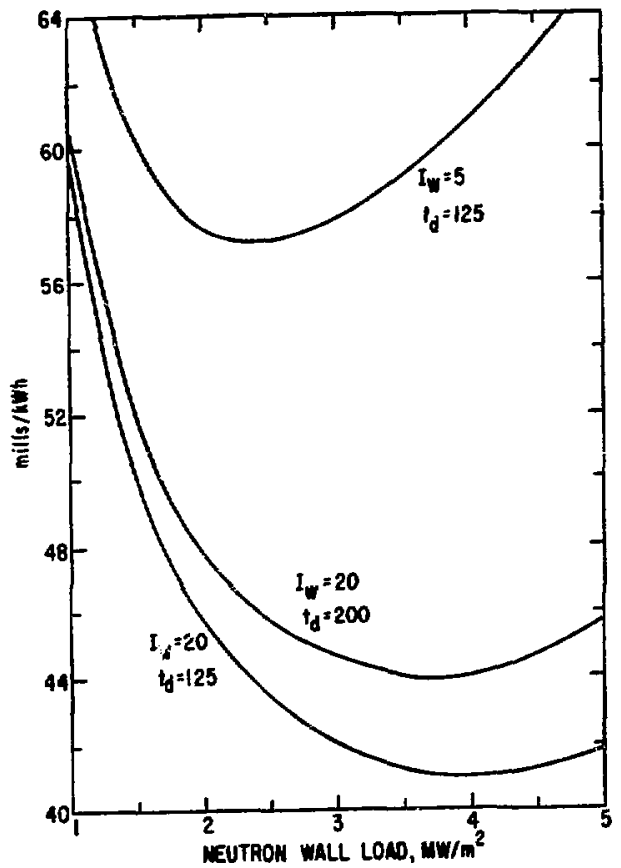

Fig. 2. Cost of energy as a function of neutron wall load. I is the integral neutron wall load in $M-g r / m^{2}$ and $t_{d}$ is the total downtioe in days for replacewent of the structural anter1a1. Results are based on fuston power of $3200 \mathrm{kN}$, aspect rat1o of 3.6 , plasma elongation of 1.6 , and $B_{t}=0.067$.

reduced, the cost of energy becomes less sensitive to moderate variations in the dotatime. This is quite iaportant as it permits flextbility in the reactor design not avallable otherwise for dentges driven primarily by the need for achieving very thort downtime; (c) a less frequent replacenent of the atructural material remults in a lower inventory of radiosctive mterials for shich worage has to be provided. (It should be noted that even for the canddate atructural anteriala with no long-tern activation, edequate radloactive storage 10 neceanary for two to flve decades); and (d) the deand on exterial resources is lese with longer life.

For a given fusion poster, plasine elongation and espact ratio, a higher wall loed iepl 18s a bigher plava density, $P_{p}$. This varies is $\mathrm{P}_{\mathrm{p}}{ }^{2} \mathrm{~B}^{2} \mathrm{~B}^{4}$. Since the plase $B$ is iffited by stabllity considerations, a higher $P_{m}$ is obtalnable only by providing a higher cernatic field as ehown in Fig. 3. This fisure shors the waximu toroidel agnetic fleld, 8 , required as a function of apect ratio and neutror, will load. The two different scales for $B_{\text {r }}$ on the ift and right of Tig. 3 correspond to two differen: ileane impurity control schems as discussod in Sec. 5 . For $\mathrm{P}_{\mathrm{m}}>2 \mathrm{kM} / \mathrm{m}^{2}$ there is $21 \mathrm{I}$ increase in the re judred $\mathrm{B}$. for evary

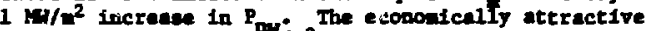

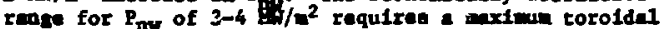
field in the range 10-12 $\mathrm{T}$ wich te conotdered accoptable for the STARPIRE desion as discused shortiy. 


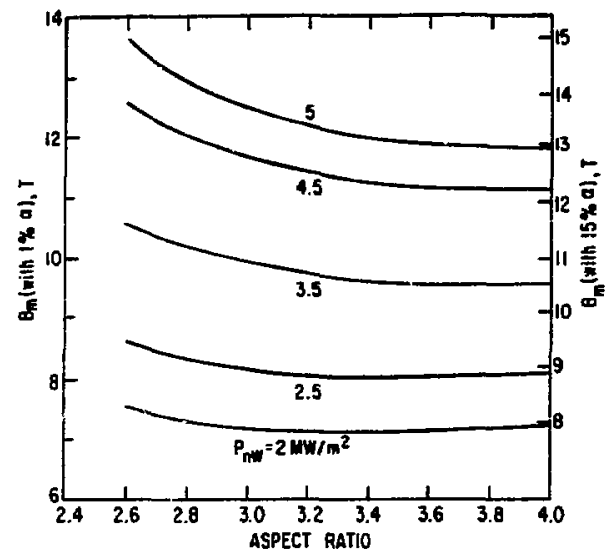

Fig. 3. $B_{\text {m }}$ as a function of $A$ at several values of $P_{\text {fu }}$ The LHS scale 1a for $\mathrm{a}_{\mathrm{a}} / \mathrm{n}_{\mathrm{DT}}=0.01$ and the $\mathrm{p}$ th scale is for $n_{\alpha} / n_{D T}=0.15$. $\quad\left(P_{f}-3200\right.$ w , $B_{t}$ $=0.24 \mathrm{~A}, A_{\mathrm{BS}}^{\mathrm{f}}=1.2 \mathrm{a}, \mathrm{A}_{\mathrm{V}}=0.1 \mathrm{~m}, \overline{\mathrm{T}}-8 \mathrm{keV}$, $\kappa=1.6$.

In 11;the of the above conetderations, a neutron wall load of $3.5 \mathrm{mN} / \mathrm{m}^{2}$ has been selected for STARFIRE. Tinis moderately high-wall load appears to be a reanonable cholce that makes it possible to design a relstively small-size react or without excessive requirements on first-vall cooling capability, aximul toroldal magnetic field, and frequency of structural anterial replacement.

\section{Plasme Beta}

Previous systems studies 5 have indicated significant econonic benefits for operating at high-average plasma-toroldal beta, $B_{t}$. Bowever, the meximul raslizable $B_{t}$ is linited by planan stability considerations. Based on recent theoret ical analysis, the relationship $\beta_{t}=0.24 / \mathrm{A}$, where $\mathrm{A}$ is the aspect ratio, has been assumed for the STARFTRE study.

\section{Toroldal Magnetic Field}

Figure 3 shows the weximurs toroldal field (B) required as a function of aspect ratio and neutron vall load for $P_{f}=3200 \mathrm{~m}, k=1.6, B_{t}=0.24 / \mathrm{A}, \Delta_{y}=0.1=$ and $\Delta_{1}^{1}=1.2 \mathrm{~m}$. The scale on the left side of Fig. 3

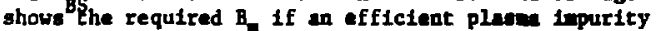
control mectuansen (e.g. divertor) 10 provided wuch that

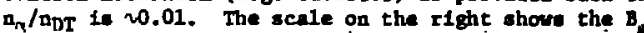
required if less efficient piasme Inpurity controi techenion (e.g. 11-1ter/vacuun ayoter, ece Ref. 1) is ut1lized such that $\mathrm{n}_{\alpha} / \mathrm{n}_{\mathrm{pT}}$ is 0.15 . Figure 4 provides wore detall about the vertation of $\mathrm{B}$ with the 1purity level for the case of $P_{n z}=3.5 \mathrm{~m} / \mathrm{m}^{2}$, aspact rat10 of 3.6 and $T_{1} \approx T_{0}=14 \mathrm{keV}$. The if power required to drive the plasen current decrences with $T_{\text {a }}$ an discused

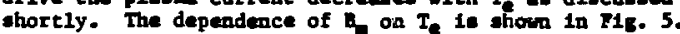

There exdats at present conalderable experfence vith BBTH muperconductor. However, it has been whow that a mgatic field of w10 $\mathrm{T}$ is the maxime practical 11nit for WETI cooled to 4,2 r at atsoopheric presaure. On the otber hand, $\mathrm{Hb}_{3} \mathrm{Sn}$ 1t capable of generatin: h1 gher fields. Aithough present experience vith $\mathrm{bb}_{3} \mathrm{Sn}$ 1. linfted, the progrees in the current technologs

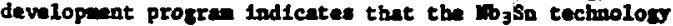
will be satiable in the STMVTIRE tim frem.

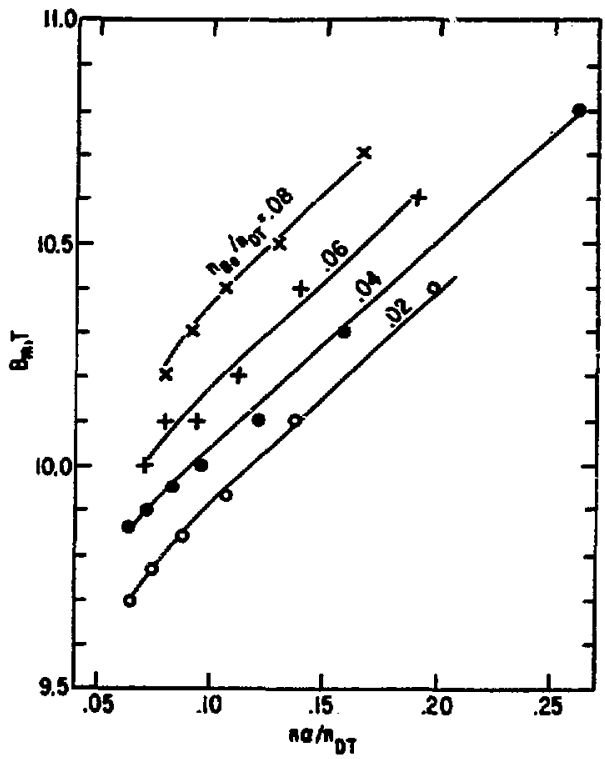

P18، 4. Vartation of the maximum angetic field with the al pha-particle concentration, $\mathrm{n}_{\mathrm{a}} / \mathrm{n}_{\mathrm{pT}}$, and

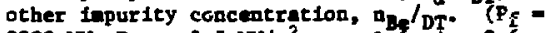
$3200 \mathrm{w}, \mathrm{P}=3.5 \mathrm{w} / \mathrm{m}^{2}, \kappa=1.6, \mathrm{AT}^{*}=3.6$, $B_{t}=0.067, \bar{T}_{1} \sim \bar{T}_{e}=14 \mathrm{keV}, \Delta t=1.2 \mathrm{k}$, $\left.\Delta_{v}=0.1 \mathrm{n}, \mathrm{R}=7 \mathrm{~m}\right)$

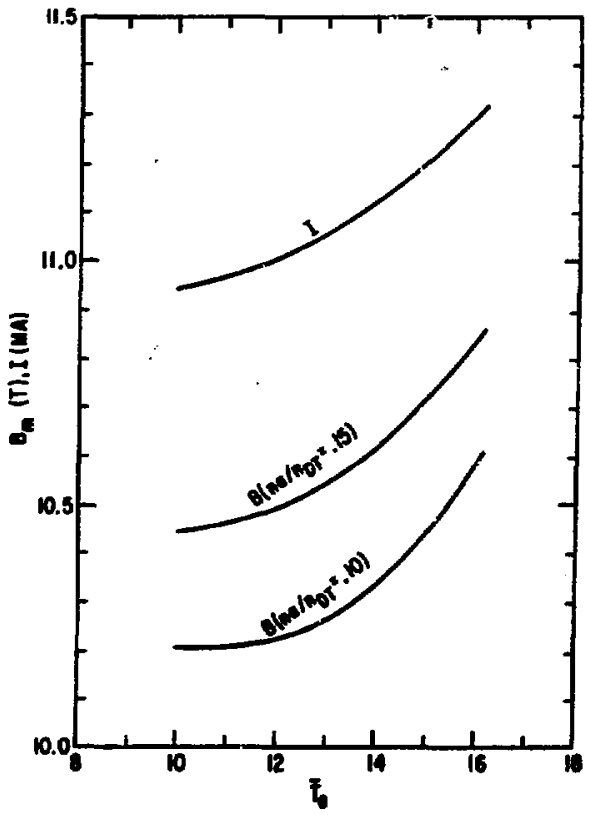

F18. 5. Variation of the mater mapetc field and plese current with the mreraye electron teperature, $T_{e^{*}} \quad\left(\boldsymbol{P}_{f}-3200, k=1.6, A\right.$ $=3.6, R-7 \mathrm{~m}, B_{t}=0.067, \Delta t_{s}-1.2 \mathrm{~m}$, $\Delta .0 .1 \mathrm{a}$ ) 
Therefore, the 10-T 11nit of MbT1 wa not Impsed as a conotraint in the STARFIRE study; the required value of the toroidal field vas deteruined froe engineering and econonic tradeof fo for the overall reactor syaten.

\section{Plesan Elongation}

The elongation ( $x-b / a$ ) of a D-ahaped plase has a significant Impact on the plasun performance, the reactor design charactertutics, and econonics. In particular, at higher $k$ the achtevable $B_{t}$ 1s higher but the required EF coll gystet becones wore complex and costly. Baned in previous work, 4,6 a value of $k=1.6$ was selected for STARFIRE. This is belleved to be nearly the upper 1foit on elongation if the laportant design goal of locating wot of the EF colls external to the If coils is to be schievable.

\section{Power Requirements for Currunt Drive}

Since STARFIRE w11 operate in a steady-state node, a particularly important aspect of the design is the mechanisn for plasma current drive. As discussed in Ref. 1, lower-hybrid if is the selected option for current drive. Relativistic electron beams are also being exandned as a backup option. An tmportant Impact of the current drive system on the reactor performance and economics is the electrical power requirements for: this system. The dependence of the magnitude of this power for the if system on key plasma and reactor design paraneters is discussed below.

The theory of lower-hybrid-wave-drive currents ${ }^{7,8}$ Indicates the ratio of rf poster denalty to current density is proportional to the electron densicy. Thus, rf power is reduced by operating at higher plasm tewperatures (lower densities for a fixed beta). However, as the plasma temperature increases above $210 \mathrm{keV}$, the fuston poser density atarte to decrease and the ratio of $\mathrm{rf}$ power to fugion power is a minimum in the range 15-18 kev., 9 In surveying reactor operation at var1ous temeratures, the desire to minimize if power calls for considering temeratures above $10 \mathrm{keV}$, but larger toroldal fleids needed to keep che total fusion power at $3200 \mathrm{MW}$ must also be acknowledged at these higher temperatures (aee F1g, 5).

In determining the dependence of reactor doaign on aspect ratio (A), for a fixed totel power and wall load and for $B_{t} \propto A^{-1}$, the total current increases going to lower aspect ratio, while the major radius and plasen density decrease. Based on the analytic formula

$$
P_{r f}=C R \bar{p}_{e} I \text {, }
$$

where $R$ is the major radius, $\bar{D}_{e}$ is the average electron density and $I$ is the platur current, the if power required to drive reactora for a series of equilibria In the range $3 \leq \mathrm{A}<4$ wa computed. Tha coeffictent c is a function of the plasin profilea, opectral sidth, and degree of current penetration; for typlcel reactor paraneters, and for both centrally paaked and surface current denelty profiles, the if power increases by $30-50 \%$ if the aspect ratio is reduced from 4.0 to 3.0 . Hence, large values of $A$ are preferrad from the rt power point of view.

\section{Mafor Radiue and Anpect Ratio}

With the funton power and neutron wall laed walected, the surface area of the plang 1s dofined, For a given $x$, the anpect ratio $(A)$ or the anjor radius (R) should be eelected in ordar to fully define the plenen geomerry; An shown previlously in Fig. 1, at $P_{m y}$ $3.5 \mathrm{Mr} / \mathrm{\pi}^{2}$, the anfor redius incrances from $6 \mathrm{~m}$ to 27.3 a If $A$ is Incrased from 2,6 to 4.0 .
The size of the reactor building, length of piping, etc., are strongly affected by the size of the reactor, In particular, by the value of $\mathrm{g}+\mathrm{a}$, where $a$ is the plase ainor radius. Notice that the variation of R + a the apect ratio is changed 1s leas than the variution in $\mathrm{A}$ alone. Dapite the reduction in the capital cost of reveral ites anditive to size when $R$ 1. saller, econonic optintzation does not necewsarily favor the selection of minimin $\mathrm{R}$. This is true for both pulaed and steady-state reactors although for different reasons.

For puled reactors, the optinum size to stpatficantly affected by the central core radius, $r_{y}$. For a given angpetic field for the oH coll, decreasing $r$ reduces the avallable volt-seconds and shorten the burn tive resulting in a lower reactor electrical output.

For steady-state reactora with no of coll the problen of the central core radius disappears. In thie case, the plasme curreat has to be driven by external means (e.g. If or REB). If the electrical power requirement for the current driver were negligibly small, then the stallest aspect ratio should be chosen so that the nufor radius 15 minimum, provided of course that there 1s adequate space on the inner alde of the torus to accomodate the TF colls and support cylieder. This is illustrated by the case $P_{\text {Tf }}=10 \mathrm{mH}$ in Fig, 6 which displays the cost of energy as a function of the aspect rat 10 .

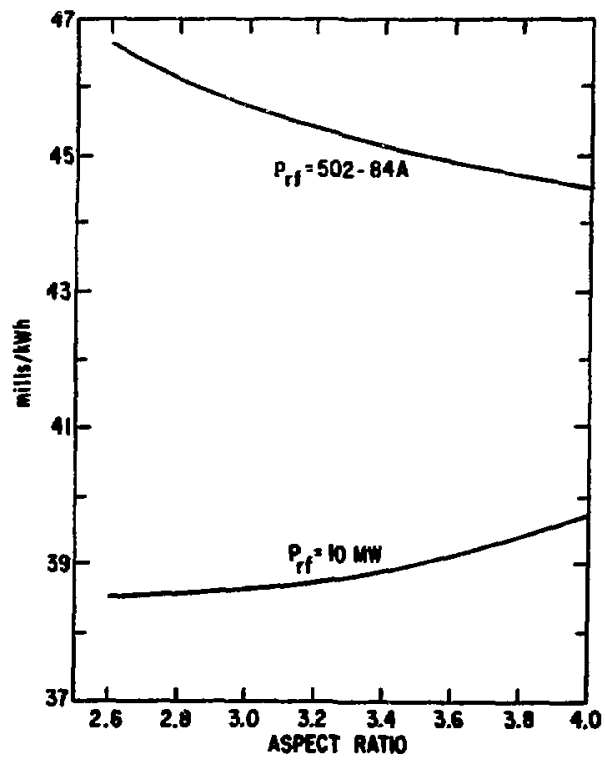

F1g. 6. Cost of enersy as a function of enpect ratio for a atesdy-atate reactor in two canes for the electricel power, $P_{\mathrm{rf}}$, required for the curreat-drive syaten: $P_{r f}=10$ and $P_{r f}=$ 502-84 \& where A is the aspect ratio and Prf 1s in vive.

Ao diacused anrisar in Sec. 7 , the electrical poiner requitroment, $P_{\text {rf, for }}$ fhe $x f$ current drive syate appenta to be relietivaly large and lacracese with lower apenct rat10. Fipuis 6 ohow the dependesce of the cont of easery on expact ratio for the cace whore $F_{\text {rf }}=$ 502-84 A, with Prf in M alectric. In this caes tb cost of enersy dacreases as $A$ increases up to $A$ i 4 . 
It is anticipated, hovever, that as a rasult of further work the rf porser requirements will be reduced signif1cant1y. This would reduce the optinim aspact ratio somenthat below A -4 . Therefore, A $=3.6$ was adopted for STARFInE. This results in anjor radiue $R-7 \mathrm{~m}$. The axiluin megnetic field required is nearly aininim at $\mathrm{A}=3.6$ a evident frol resulta in Fig. 3 .

A major Incentive for considering relativintic elactron beaso (REB) as a backup option for plasma current drive is the wuch lower electrical power requirenent: compared to those needed for the rit syatem. Present estimeter Indicate that REB electrical power requirenents are in the range 10-20 aw compared to ?150-200 w for the rf systan. Alauning that the cap1tal cost is roughly the sare for boch syatens, the coat per unit power 1a w8\% lower with REB compared to that with the rf aystem. However, the present state-of-the art for REB makes it difficuit to quantitet ively evaluate the technical and operational problens that wight arise as the concept is Investigated in more detall.

\section{Inner Blanket/Shleld Thickness}

The thickness, $\frac{1}{B}$, of the blanket and shield on the inner side of the Eorus, or more precisely the distance In midplane frow the plas side of the first wall to the location of the marimul toroldal angetic fleld, has a substantial 1mpact on the reactor size, the required strength of the magnetic field and reactor economics. A comprehensive Investigation of the optimum value for $\Delta \frac{1}{1}$ has been cerried out previously. Io The detalls of Ehis prevtous work will not be reported here, but the results are briefly stated.

For a given $P_{f}, P_{n y}, F_{t}$, and najor radiue, the advantages of a spoller $\Delta P^{\prime}$ are (1) lower aaximin angnet1c fleld; and (2) larger ceatral core (OH) radius, $r_{v}$. In pulsed tokamaks, the 1mpact of the value of $A_{B S}^{1}$ on $r_{v}$ is large and becomes critical for low $P_{\text {f }}$-high ${ }_{P_{n u}}$ designs. In a steady-state tokank with no ot solenold, the primary incentive for reducing $\Delta_{B S}^{1}$ is to reduce the maximum magnetic fleld required.

On the other hand, there are several penalities for making $\Delta 1$ too smail. The increase in the radiacton field when $A_{\text {i }}^{1}$ ia decreased rewults in (a) increase in the resiltivicy of the sabilizer material and a need for increasing the awount of the atabllizer to satisfy the cryogenie stability requiremate; (b). decrease in the critical current denelty of the superconductor necessitating the uce of wore superconductor; and (c) in increase in the heat-generation rate in the IF coll since the increase in the porrer requirements for the TF coll aryogenlc syaten can be so large that the reactor net electrical power output is ser1ously reduced.

For the reference dealgn of STARPIRE, a value of $\Delta_{\mathrm{BS}}^{1}=1.2$ a wa aelected based on careful conalderathoss of the above tradeoffs. Th1s value includes 225 vold to account for the vacuun eap in the TF coll and the use of hellum coolant in a portion of the laner blanket, if secessary. The shield consiate of a conbination of tuapeten, boron carbide, laed, and a structural mterial.

\section{Outer Ler of the II Colia}

For a given mor radius (i), plasm lonar radiun

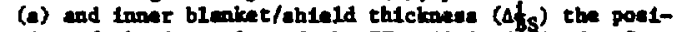
tion of the 1nner les of the $T F$ coll is difined. In ordar to fully dafine the D-hape of the IF coll, the - Ize of the vertical or horizontal bore wut be celected. We will diacusa thia cholee in tarm of $R_{2}$, the anfor radius of the midpoint of the outer las of the TP coll. $R_{2}$ is the of of the anjor radiue, firat-iall ninor radius, outer blanket/shield thicken ( $\Delta_{\mathrm{MS}}^{\mathrm{O}}$ ), clearance $\left(\Delta_{c}\right)$ in the aidplane fron the outer edge of the thield to the TF coil and helf of the TF coll thickness. The cholce of $R_{2}$ hes a ignificent inpect on any of tha rasctor characteriatics and cost an discussed below.

Wich the reactor parameters defined in the prev1ous sections ( $R, a, \Delta_{y}, B_{m} \Delta \frac{1}{B}$ ) the only raneining parawetars that af fect $R_{2}$ are $\mho_{B S}$ and $\Delta_{c}$. The neceasary value of $\Delta_{B S}^{D}$ varies with blanket and shield material and coolant cholces. As a goal, the materials in the shield should be chomen to heve inherentiy low longliyed radioactivity even if they are less efficient in radiation attenuation. For typical aterial choicea, the required $s_{\mathrm{BS}}^{\circ} 1 \mathrm{i} i .3 \mathrm{a}$ and 11.8 a for blanket with water (or lithiun) and hellus coolanta, respectively. The clearance frow the outer edge of the shfeld to the TF coils is required for several engineering reesons; the most doninant of which is to accomodate the coolant anifolds. The raquired $R_{2}$ 1a, .12 a for water or 11thium coolants compared to 213 m necessary for hellum coolants.

The econonics analysia stiowa a substantial penalty for increasing $R_{2}$. The cost of enorgy 1ncreases by $23 \%$ for each additional neter increase in the value of $R_{2}$ bejond $12 \mathrm{~m}$. The cause of this penalty is that the value of $R_{2}$ directly influences the size and weight of the $T F$ colls and the1r support stzucture, the stze of the reactor bullding, the length of the piping for the heat traisport syatew, and the size of the externally loceted EF colls. For example, by increasing $R_{2}$ from 12 to $14 \mathrm{~m}$, the aupere-turns and stored energy in the EF coils nearly double.

It should te noted that in order to keep the fleld ripple at the plasma to an acceptable level, the value of $R_{2}$ should be greater than a certain ninimin. The einimin value for $R_{2}$ is larger for a sanaller nuber of TF coils. A relartvely sall number, 12 , of IF coila his been chosen for STARFIRE to enhance resctor meintaluability. This makes extending the TF colls as a reane of satiafying the fleld ripple criteria econonicelly unatractive. Therefore, the alternative of an 1eponed ifield-ripple correction ayaten (e.g. seddle colls or 1ron blocks) vill be provided if necessary.

\section{References}

1. C. MAKER, et 1., "STARFIRE - Comerc1a1 Tokawak Power Plant Overview," (presented at this conference).

2. M. ABDOD, et 2l." "ANL Paraetric Syatess Studies," Argonne Naticnal Laboratory, ARL/BPP/ITH-100 (1977).

3. D. DE FREECE, et al., "Funion Firat He11/ Blanket Syatome Anclye1a," EPRI, RP-472-1 (1977).

4. H. ABDOU and 2. El-DERIMI, "A Comparative Study of the Perfornance and Economica of Advanced and Conventional Structural Materials In Fusion System," Proc. lat Top. Htg. Fusion Reactor Nateriais, Cost-790125 (1979), to be laaued.

5. M. ABDOD, et al., "Impact of Mejor Desigo Paranters on the Econonlca of Toknalk Porrer Plants," Proc. IAEA Wowkhos on Fusion Reactor Design, October 10-21, 1977, Paper wo. IAEA-TC-145/44, p. 673.

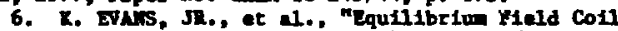
Constderations for Tolkenal lanctors," Proc. 3rd ATS Top. Atg. Technology of Controlled inclear Fusion, coir-780508, Vol. II (1978), p. 1084.

7. W. J. FISCH, Phye. Pov. Lettere 41, 873 (1978).

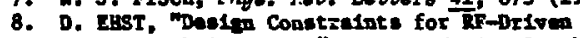
Steedy-State Tokenak leactora," Argonne Nat lonal Lab., AML/FP/TH-120; also mal. Fusion, to be lasued.

9. S. I. TUL, D. rupun, and D. R. COth, Plasm

Fuaion Center, MIT, I1-79-7 (1979).

10. H. ABDO0, J. whel. Nat. 2, 147 (1978). 


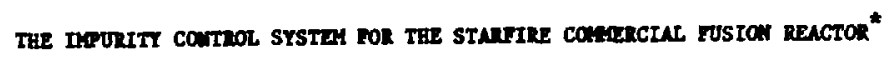

J. H. Brooke, C. C. Baker, and H. C. Stevens

Argonin Mational Laborators

Arsonne, Ill1no1s 60439

C. A. Tracheel

MeDonnell Dougles Antronautice Comany

St. Loule, Liseour1 63166

\section{Sunery}

The STARTIRE 1mpurity control syaten is based on a low-2 couted linter/vacuu aysten which collects and purpe bout $30 \mathrm{z}$ of the particle flux at the edge of the plane. This pupting efficiancy, when combined with about a 1.5-T additionel argin in the toroidal $\mathrm{mg}$ netic field, is mufficient to malntain the stedy-atate helful concentration to $10 z$ while perafte1ng a tritiu. buraup fraction at $210 \mathrm{x}$. In order to keep the heat load on the linter to reasonable litetts, about $80 z$ of the alpha-particle energy is radiated to the first wall by infecting a very saall amount of appropriate 1mpurity fons.

\section{Introduction}

STARFIRE 1. a conceptual denign stud of a comerctal coksinek furloa resctor. ${ }^{1}$ The mojor paraneters of STARFIRE are $R=7 \mathrm{k}, \mathrm{A}=3, K=1.6, I_{p}=11 \mathrm{kA}$, and $B=0.07$. The fusion power is $3200 \mathrm{~kW}$ and the net electrical power 1s 21150 me. The reactor is operated in steady state uning a lower-hybrid rf systen to Induce and mintein the planga current. In keeping with the general goal of this project, this 1mpurity control system has been designed so as to bu as elaple an posaible. Another goel is to ainietze the plant tritlun inveneory and this has also influenced the cholce of the impurity control oysten. The refereace ilpurity control aystan is based on 11niter/vacuua gyoten together with low- $Z$ contings used on an exposed aurfaces.

\section{Liniter/Vacuun Syaten}

The function of the liniter/vacuun syaten in based on the general princtples outlintd in Ref. 2 which is basically to collect outward diffueing particl $=3$ on the linter and to purp sone fraction of then. The 11eiter/ vacuum syatei 10 shown conceptunlly in 718 . 1. Two "belt-type" IIndtare are used, located at about the top and botton of the plasal chaber. The torosdal 11atters are fairly anil in the poloidel crose section; typically the cotel linter erea would be less than $5 x$ of the firet-vall area. Each liniter has an adjacent vacuu siot which also extende around the torus and penetrates the f1rst wall and blaket. Each olot contains a atep, w shown, to reduce neutron streesing. In the molecular flow region this step has elnial effects on the conductance, the only conalderation being the additionel lot length required to provide the step. A large volue plenum exiets between the outsida of the firat-vall blanket and the indide of the shield. Tenty-four 1.7- dianter, 1.5-1 lons vecuu ducte penetrate the ahield and provide access for liquid heliue eryogeatc pupe which ere used for all of the puping. The Ilquid hellua cryogente purp will be of the compound rariety in whtch bydrogen and its 1eotopes are puped by cryocondenation on a 11quid hallucooled panel and helliw is eryosorbed on a 4.2-K woleculer oleve surface.

The lintter in FIg. I in abown an trimgular for 111uvtration only. Thile the linitar has not been

* Work supported by the U. S. Dapartent of Energs. deeigned in detall, the actual shope should resemble that shom in F1g. 2. The key factor affacting the design of the 1iditer and ite feanbility 10 the peak heat load on the linfter leading edge. The peak load defends on the scrapo-off th1ckeses, the hent transported to the inteer, and on the lintter ahape. These have been anelyzed as follows:

\section{Scrape-off Thickneas:}

The width of the scrape-off thicknese can be conputed by considering a single liniter, for aimplicity, and using the coordinate systen shown in Fig. 2 . Conalder a test particle that, on Its orbit around the plasan, has fust mised the 1initer and is initially at $x=0, y=0$. In order to return to the vicinity of the liniter, the particle mat make one revolutiont poloidally and $q$ revolutions toroidalily, where $q$ is the safety factor. In doing so, the particle diffuses outward radially and so does not return r.o $x=0$ but inatead hits the lifiter at a diatence, $x$ - "s" froe the frout fase. This distance which can be interpreted as an e-fold.ing length for particle transport in the screpeoff $20 n e$ can be conputed by:

$$
\delta=\sqrt{D_{1}{ }^{2}} \text {, }
$$

where $D_{\perp}$ is the porallel diffunion coefficient characteristic of the edge region, and $\tau$ is the "flight" $t$ ine for the particle to return to the 1initer. For a path length, $L$, and using the Ion theralal velocity, $t$ ie given by:

$$
\tau=\mathrm{L} / \mathrm{V}_{1},
$$

where $v_{1}=\sqrt{\mathrm{RT}_{1} / \mathrm{I}_{1}}$. Ualog a Dohn diffusion coeffictent for DT Ions:

$$
D_{1}\left(m^{2} / a\right)=0.0625 \frac{T_{e}(e V)}{B(T)} .
$$

The distance $\delta$ is found fron Eqs. (1)-(3) to be:

$$
\delta(n)=3.176 \times 10^{-3} \sqrt{\mathrm{n} / \mathrm{B}} \times \mathrm{T}^{1 / 4} .
$$

For the watem of two linter: ench edge particle oaly bas to go half as far and so $\mathrm{L}$ - $\mathrm{mllq}$. For STARTIne, $q=3.6, \mathrm{~L}=80 \mathrm{~m}$, and $\mathrm{B}_{0}=5.6 \mathrm{~T}$ in the plase center which cen be taken as on average B for use in Eq. (4). Based on the eotianted hent flux (to be didcuived), part1cla flux, and on the shenth rodel of Ref. 4 undar the asouption of apece-charge linted electron re-aisston at the liniter, the computed electron-adge tempernture is $\mathrm{T}_{\mathrm{g}}=1500 \mathrm{D}$. These paranters give $\delta-7.5 \mathrm{~cm}$ from Eq. (4). This value of $\delta$ is for the particle flux in the scrapeoff. Altbouth theoreticelily one wight arge for a faster fall-off for the aners flux, recont vasuremente ${ }^{3}$ for FLT whos marly identical particle and coexey tall-off rates and this bes been ansund for this study. 

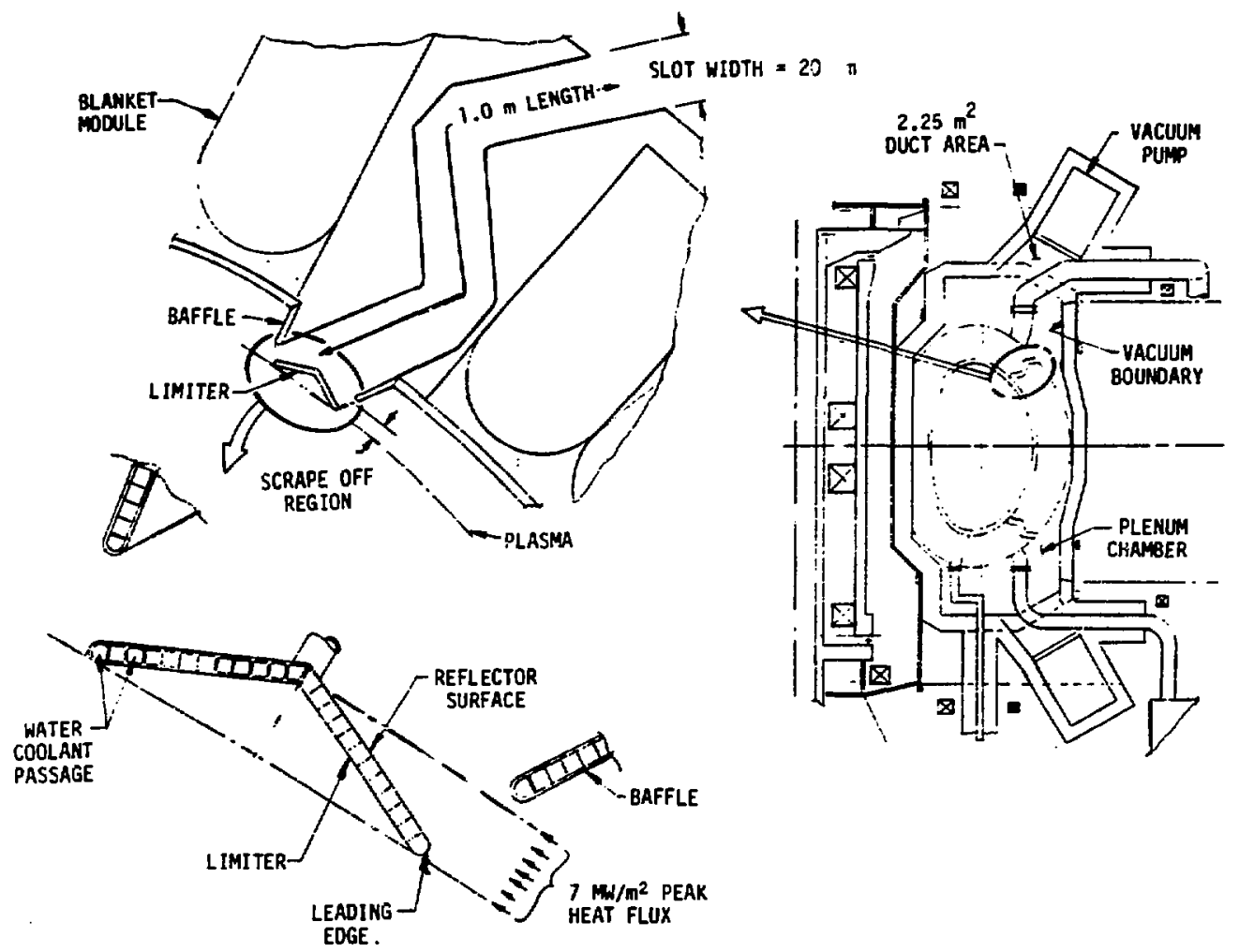

Fig. 1. Iimiter/vacuule duct concept.

\section{Heat Plow}

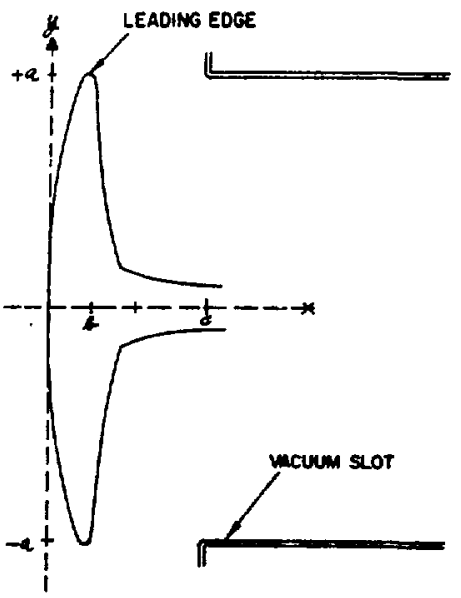

Fig. 2. Liatter saometry.
The heat flow to the liniters cin be estimated using two power balance equatlons, one for the core plasme and one for the edge region where the latter alght be defined an perhaps the last 5 or $10 x$ of the plasw volune. For the core region:

$$
\mathrm{P}_{\mathrm{\alpha}}+\mathrm{P}_{\mathrm{RF}}=\mathrm{P}_{\mathrm{TR}}^{\mathrm{core}}+\mathrm{P}_{\mathrm{rad}}^{\text {core }}
$$

whore $P_{g}$ is the alpha-heating power, $P_{p_{F}}$ is the red10frequency poser uned to drive the stendy-etete planma current, Pcore is the transport power leaving tha core, and Pcote if the power radisted fron the core. Equation (5) wat be satiefied for the plase to be in overaII thernal equilibriue. Our appronch to atinfy Eq. (5) and at the wane tin to ininize the transport power, 1s to radiate sa wuch powex as possible, by injecting anll anounts of hish-z material into the planae. One of the noble sesee would be e typical meterial for this purpose. This "entanced rediation" node not only mikas the lintter danign eanter; by reducing the transport heat to $1 \mathrm{t}$, but ay 100 be core attractive then onhaneing the onersy diffusion by weth mans as ripple colls or the like.

The tranuport porer from the core is given by:

$$
P_{T R}^{\text {core }}=\frac{u_{e}}{t_{e}}+\frac{u_{1}}{\tau_{1}},
$$


where $U_{e}$ and $U_{f}$ are the electron and lon kinetic energy contents in the plasm, respectively, and $\tau_{2}$ and $\tau_{1}$ are the electron and lon-energy contalnent times. It 18 , of course, not elear what the containent times uill be in future tokamaks but the common prescription of using Alcator-type acallag for the electrons and one-third neoclaselcal scaling for the lone is a typleal cholce that might hopefully yield conservative estimates. For STARFIRE this gives:

$$
\begin{aligned}
& \tau_{e}=5 \times 10^{-21} \mathrm{~N}_{\mathrm{e}^{\mathrm{a}^{-2}}=4 \mathrm{~s},} \\
& \tau_{1}=\frac{\tau_{\mathrm{BAN}}}{3}=\frac{9.8 \times 10^{6} \sqrt{\mathrm{AT}} \mathrm{I}_{\mathrm{p}}^{2}}{\mathrm{~N}_{\mathrm{e}}{ }_{\mathrm{eff}}} \times \frac{1}{3}=19 \mathrm{~s},
\end{aligned}
$$

where $t_{B A N}$ refers to the banana regine scaling law of ReE. 5. The plasma kinetic energleg are: $U_{e}=620 \mathrm{MJ}$ and $\mathrm{V}_{1}=553 \mathrm{MJ}$, which yield $P_{\mathrm{TR}}^{\mathrm{core}}=184 \mathrm{MW}$.

Since $P_{\alpha}=640 \mathrm{WW}$ and $P_{R F}=120 \mathrm{WW}$, the required radiation power, given by $E q . ~(5)$, is then $\mathrm{P}_{\mathrm{RF}}^{\mathrm{core}}=650$ wW. A global analysis using typical peaked temperature and density profiles atd using the coronal equild.brium radiation model of Ref. 6 Indicates that this amount of radiation can be achieved with $50.1 \%$ of xenon added to the plasma or a somewhat higher amount of krypton. This level of xenon seens acceptably sma!.1 but the general question of profile control needs to be examlined more closely. ten as:

The power balance for the edge region can be writ-

$$
P_{\mathrm{TR}}^{\text {core }}=P_{\mathrm{TR}}^{1 \mathrm{~lm}}+\left(P_{c x}+P_{\mathrm{rad}}^{\text {edge }}+P_{\mathrm{mlsc}}^{\text {edge }}\right) \text {. }
$$

Where $\mathrm{P}_{\mathrm{TR}}^{\text {core }}$ is the Input power to the edge, $\mathrm{P}_{\mathrm{TR}}^{11 \mathrm{~m}}$ is the transport power from the edge to the limiter, $P_{\mathrm{Px}} \pm \mathrm{s}$ the powar assoclated with charge-exchange events, peds is the edge radiation power, and the last term is a miscellaneous power which would Include, for exarple. Ionization of refluxing lons and Impuritieg. Because of the terms in the brackets of Eq. (6), Plim will be, in general, sone fraction $\gamma$ less than one of pcore Using a tjpical value of $\gamma=0.5$ then gives for the transport power to the Iluters: $\mathrm{P}_{\mathrm{TR}}^{11 \mathrm{~m}}=92 \mathrm{MW}$. The power flux to each limiter is deterained from this power and from the limiter geometry. Since there are four limiter surfaces, the heat flux, along the plane $y= \pm a$ 18:

$$
q(x)=\frac{P_{T R}^{11 m} e^{-x / \delta}}{8 \pi R \delta}, \text { for } 0<x \text {, }
$$

for which $\delta=0.075$ gives:

$$
q(x)=7.0 \mathrm{e}^{-x / \delta}\left(\mathrm{sw} / \mathrm{m}^{2}\right) \text {. }
$$

The heat flux on the urface of the limiters will be decreased substantielly by the area factor ancoeiated with the sloped ourfacea. However, the landing edges will recelve the full hent flux and wo the location of the leading edge is a criticel choice in the Ifulter design. Uaing a criterion, for exanple, that the peak heat lond not exceed $4 \mathrm{KW} / \mathrm{m}^{2}$, the leading edge nuat be displaced a distance of $b$ */2 from the front face. In addition to the transport heat flux, che lindter will recelve an $X-r e y$ radiation flux of $20.7 \mathrm{~kW} / \mathrm{m}^{2}$ from the glease and a noutron flux of 3.5 MN/ $/ \mathrm{a}^{2}$. Because of the hith heat loed, the leadng edge w111 be conatructed of a high tharnal conductivity cube, such in AYZIRC Copper No. C15000. Th1e alloy
(OHFC copper plus zirconfum) in suggezted because it has higher creep strength than OHFC alone. Analygis of a OHFC tube for the General Atonlc THS 11witer under sioflar condition has shown that a $1.25-\mathrm{ce}$ diameter $x$ 0.125 co wall tube with $10 \mathrm{M} / \mathrm{S}$ cooling water resulted in a maximuln wetal temperature of $280^{\circ} \mathrm{C}$. Ac the predieced stress and temperacure the OHFC copper would elongate v17 In 2 yr of operation. The rest of the 11miter could be constructed of a double-wall sandulch with water coolant. The smaller heat load on the rest of the 11nlter will result in 91gnificantly lower temperatures which should avold the creep 11mitations of copper. It should be noted that heat transfer and heat transport offer no extreme degign hardship up to $9 \mathrm{MH} / \mathrm{m}^{2}$ for med lum-to-ingh thermal conductivity materlals. The 11miter Ilfetime with these materials is most dependent on radiation damage. Several design geowetrles are now beIng Investigated along with the prospects of realistically considering the use of the molybdenum alloy TZM.

Further design and analysis ef forts are required to quantify the limiter configuration and 1ifetime. Both the time required to replace a limiter and its iffetime are critical to its viablitty in power reactor operatlong. A life goal of $4 \mathrm{yr}$ has been established for the 11miters.

\section{IImiter Performance}

The number of particles removed by the limiter/ vacuum system depends on three factors: (1) the fraction $f$ of the particles from the plasma impinging on the back surfaces of the 1 Intter, 1.e. $b \leq x \leq c$; (2) the probability that an 104 impinglng and reflectsng oif the back surface (as a reutral) will enter the vacuua slot; and (3) the probability that an ion entering the vacuun slot till ulltmately be pumped out.

The net removal probability depends on a combinatIon of these factors. Considerlag the Eact that particles can make multiple bounces between the vacuum slots and the liniter surface, the cumulative probability that a particle, diffusing from the plaema will be putped is:

$$
\begin{aligned}
P= & f\left(P_{1} P_{2}+P_{1}\left(1-P_{2}\right) P_{1} P_{2}+P_{1}^{3}\right. \\
& \left.\times\left(1-P_{2}\right) P_{2}+\cdots\right\},
\end{aligned}
$$

wich sume to:

$$
P=\frac{f P_{1} P_{2}}{1-P_{1}\left(1-P_{2}\right)} .
$$

In general, the vacuun lot, port conductance, and pump capture probability, and hence $P_{2}$ 1s falrly low, but $P_{1}$ can be made fairly high so that atons can have many chances to enter the vacuum slots and be pumped. A problea colmon to all impurity control schemes is that it is easer to pum hydrogen than hellua; juat the opposite of the desired situation. Nevertheless, calculat lons ${ }^{8}$ using the vacuun aystem described earlier indicate that 1 value of $P_{2}=0.25$ for hellum 1s obtatanble, For $a$ linfter design with $b=0.5 \delta$ and $a$ width $c * 2 \delta$, about $40 \%\left(e^{-0.5}\right)$ of the particle flux will hit the front faces and about $10 z$ will be lost to the first wall, giving a fraction $f=0.5$ going on the back surfaces. The probability $P_{1}$ depende on the lindter width to vacuum lot he1ght rat 10 and dapende on the scattartng angle dietrubution for lons and aeutralo 1 pinging on che Iinter surface. Prelininary calculations ohow that a value of $P_{1}=0.85$ is obtainable without uning an excesivively large vacucie elot. This comblation of paraneter: reaulte in an overall probebility of $P=0.3$. Alternately, this result mane that the reflection coefflatent for hellus is $R_{\alpha}=0.7$. 


\section{Yeliue Concentration}

The ateady-state hellun concentration in the pleave can be found by equating the elphe-porticle production rate with the hellua removal rate:

$$
I_{1}=\frac{N_{\alpha} Y}{\tau_{p}}\left(1-R_{\alpha}\right) \text {, }
$$

Where $I_{\alpha}$ 1s the alpha-production rate, $\mathrm{H}_{\alpha}$ is the average helfue deatity in the plase, $v$ is the platen volune, and $t_{p}$ 1s the particle contalnment time. Solving Eq. (9) fot the fractional heliue concentration gives:

$$
\frac{N_{x}}{N_{D T}}=\frac{I_{Q} T_{p}}{V N_{D T}\left(I-R_{\alpha}\right)} .
$$

For the STARFIRE paraneters:

$$
\begin{aligned}
I_{d} & =1.1 \times 10^{21} \mathrm{~s}^{-1} \\
T_{p} & =2 \mathrm{~s} \\
v & =820 \mathrm{~m}^{3} \\
N_{D T} & =1.0 \times 10^{20} \mathrm{~m}^{-3}
\end{aligned}
$$

and for $R_{\alpha}=0.7$, the fractional concentrotion of hellum 1s about loz.

\section{Sputcared Impurity Concentration}

For the STASFIRE deeign o11 surfaces expoeed to the plasas, 1,e. the first wall and 11piters, are coated with a low-z macerial. The notivation for low-z coating: have been discuared in several reactor atud1es, e.g. Ref. S. Unlese the planem-edge temperature can be kept very low ( $550 \mathrm{eV}$ ) there any be too much radietion fron the sputtered bare atel (copper, wlybdenua, etc.) to perait ignition. 5 In eddition, at even moderate edge tenperaturee there ie the posesbil1ty of a runaway sputtering oituat ion because the celfaputering coefficients of the bare metal can be grester then unfty." Low-Z contings avold these problems: the eelf-suttering coefficiente ere consider:bly lese then unity, ${ }^{9}$ for all edge teperatures; and secondly, the low-2 lons will be fully stripped over all or wet of the plaen renulting la much lees rediatfor then fron the bare metal. A typical cholce of coating meteriel 1. beryllium but others euch as BeO, $\mathrm{B}_{4} \mathrm{C}, \mathrm{C}$, and SIC are also candidates. (For convenlence, the coating anterial will be referred to an berylliun.)

A key concern uf the low-Z conting is the quantion of the eroeion of the conting by eputtaring. However, this concera wy be amellorated by the fact that berylI1um (and other materiale) tend to at1ck very woll to themelves. If the oticking probability were unity, which it gearly 1e, then if as wuch batrllitu iepinged on the 11niter, from the plasen, an wa oputtered, there would be no net eroelon of the linter. The required berylliua conceatration al the occur, tron charge-exchange eputterlas of the conting on the firat well (which becaues of 1 ta large eurface aree could probably be racosted annulily), or it wigt be necaleary to add emil anoute of berylliue directly to the plase, e.g. with the fuel etrean. The dinimie concentration of berylliue under this aesumption ia given as followe:

The numar of beryllien atos aputtered from the conting por eacond is given by:

$$
y_{z}^{-}=\left(\frac{N_{D \tau^{V}}}{\tau_{p}}\right) s_{D r}+\left(\frac{N_{\alpha}^{V}}{\tau_{p}}\right) s_{a}+\left(\frac{N_{z}^{V}}{\tau_{p}}\right) s_{z},
$$

where the term 1n pareatlieate repreaent the fluxes of Dr, helluw, and berylliw to the linter and the $5^{\prime}$ : represent the oputtering coefficlenta. The net source of berylliu to the liniter is given by:

$$
\mathbf{r}_{z}^{+}-\left(\frac{N_{z} V}{\tau_{p}}\right)\left(1-R_{z}\right) \text {. }
$$

where $R_{2}$ 10 the reflection coeffictent of berylliun. For no net eronion:

$$
\mathbf{r}_{z}^{+}-\mathbf{r}_{z}^{-}
$$

which therefore glves for the froctional steady-g' ate berylliw concentration:

$$
\frac{N_{z}}{N_{D T}}=\frac{S_{D T}+\left(N_{a} / N_{D T}\right) s_{Q}}{1-R_{z}-S_{z}} .
$$

Uning the following valuee of aputtering coeffi-

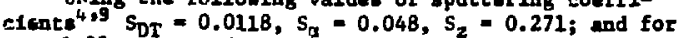
$\mathrm{R}_{\mathrm{z}}=0.05$, and $\mathrm{N}_{\alpha} / \mathrm{N}_{\mathrm{DT}}=0.1$ gives $\mathrm{s}_{2} / \mathrm{NDT}=0.025$ at the required fractional concentration of berylilum in the plasma, for the no-eronion condition. A reference value of $\mathrm{N}_{2} / \mathrm{N}$ LT $=0.04$, however, bat been aneurned for the dealgn, to be sonewhat conservative.

\section{Conclusion}

The 1epurity contzol systen for STAREIRE consists of a ileiter/vacuun system together with low-z contIngs. Although wore vork is needed on the deteiled dealgn and on the plasm engloeering, the calculations outlined here 1ndicate that the lindter concept in fenstble for - toknalk reactor. The liniter/vacuum oysten aloo appears to be wuch simpler then any type of divertor, or alternate fapurfity control syoten.

\section{References}

1. C. BAKuR, et al., "STARFIRE - A Comarcial Toknnk Reuctor," see these Proceedinge.

2. J. N. BBoOxs, "New Impurity Control Mathode for a Tokanak Fusion Renctor," Proc. 3rd ANS Top. Htg. on the Technology of Controlied Nuclear Fubion, Sante Fe, New Kextco, May 9-11, 197B, CONF-780508, Vol. II (1978), p. 873 .

3. G. M. MC Cractus, at al., "Plux and Enerery of Deuteriun Incldent on a Lidter-Like Probe 1n PLT," Princeton Plesan Phyolce Lab. PPPL-1569 (1979).

4. J. M. BRooks, "Kinetic solution of the Shenth Region in a Fusion Racecor," Argonne Mationel tab., ANL/FEP/ML-124, to be issund.

5. W. K. STACTY, JR., et al., "Toknak Experimontal Powar Reector Couceptual Dea1gn," Argonne Nat1onal Leb., AIL/CTR-76-3 (1976).

6. D. POST, et al., "Steady-state Rediat1ve Cooling Retee for Low-Denesty Hith-Teuperature Plaume, Princaton Planad Phyalce Lab., RPPL-1352 (1977).

7. GAC Project Staff, "GA Tis Project, volv: panetor Raector Engineering and Deelgn," General Alonic Co.. CA-A15100 (1978).

8. P. A. Frm, et al., Mofitlun Hadlias and Vacuen conelderatione for the STAurise conerctal Toknunk Reector," ece these Eroceedlage.

9. D. L. SirLTz, "Phyoleal Sputtering Hodel for

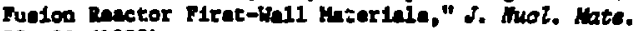
75, 20 (1970). 
ASSESSABI OF SOLID BREEDING BLANKET OPTIONS TOR COHERCIAL toKAMAK REACTORS

\author{
D. I. Satth, R. G. Clerer \\ Argoane National Laboratory \\ Argonne, T111note 60439
}

and

J. H. Davis

MeDoanell Douglas Astronautics Coapany

St. Lou1s, Missour1 63166

\section{Sulery}

Th1s otudy exanines the materials and design inplications retarding the use of solid breeding anterials with respect to compatbility with structure and coolant, tritium processing, chemical and radiation stability and theral-inydraulics, Four solld breeding anterialo considered, $\mathrm{vIz}, \mathrm{LI}_{7} \mathrm{~Pb}_{2}, \mathrm{LI}_{2} \mathrm{O}, \mathrm{LI}_{2} \mathrm{SIO}_{3}$ and L1h10 $\mathrm{O}_{2}$, ara representative of the metalilc and ceramic compourds avallable. The major design problens reparding the use of golid breeding materlals relate to the linited range of operating temperatures accepcable for tritiun release and chemical stability or conpat1bility. The allowable ranges of breeder temperatures fur which 1o-situ tritium recovery 1s potentially viable are evaluated for the candidate breeding anterials.

\section{Introduction}

L1thiue in sone form appears to be the pnly wecerial aultable for breeding tritium in a conpiercial fuaton reactor. In addition to 11quid 1ithisil, several solid lithium compounds are potentially viable tritium braeding terials. Of the relatively large number of atable 11thium compounds, three types of 11thium compounds are the most promising. These include the Eetallic compound $\mathrm{LI}_{7} \mathrm{~Pb}_{2}$, I1thium oxide $\left(\mathrm{LI}_{2} \mathrm{O}\right)$, and the complex oxidea $\mathrm{LI}_{2} \mathrm{SiO}_{3}$ and $\mathrm{LAAlO}_{2}$. Although other compounds have been proposed, the compounds liated bera are the favored compound of each type. For example, $\mathrm{L}_{1 A 1}$ is similar to $\mathrm{Li}_{7} \mathrm{~Pb}_{2}$ in wany respecte, bowever, $\mathrm{L}_{7} \mathrm{~Pb}_{2}$ provides ouper1or breeding capability because of the neutron multiplication of the lead and 1. the favored compound of this type. Iithlum oxide 19 unique because of 1 ts high lithium atos density and higher meiting temperature compared to compounds ach an $\mathrm{LI}_{2} \mathrm{SI}$ and $\mathrm{LI}_{2} \mathrm{C}_{2}$. The $\mathrm{LI}_{2} \mathrm{SHO}_{3}$ and $\mathrm{LMIO}_{2}$ generally provide a better combination of high temperature stablifty and high lithfum atom density compared to other couplex compounda.

The critical properties of these prinary candidate braeding mater 1 ials are aumarized and their viability for tritiun breeding in a cownercial tokmak reactor blanket io acessed in thia paper. Aspects conoldered Include physical properties, neutronics propartiea, chenical tability and compatibility and tritlue ralease characteriotics.

\section{Fryalcal Propertiea}

tey physicel properties of the primary candidete breeding material are muarized in Table 1. Aleo. thown for comperieon are the corresponding properties for 11quid 11thiue. of the colld breeding meteriels conoldered, $\mathrm{L}_{1} \mathrm{~Pb}_{2}$ has the loweet welting temperatura, and hesce, the lowent maxime oparating temperature.
Th1s compound also has a agnificantly higher deasity than the ceranica. The unique feature of $\mathrm{Li}_{2} \mathrm{O}$ is the h1gh lith1umaton density. However, as w11l be discunced in mote detall later, the effective denalty of $\mathrm{LI}_{2} \mathrm{O}$ and the othar ceramics will be reduced because of tritium release requirements. Thermal conductivity is an important property, however, the date for these compounds are very limited. The value for $\mathrm{Li}_{7} \mathrm{~Pb}_{2}$ is eatimated from data for sinilar types of compunds. Figure 1 sumarizes avallable data for $\mathrm{Li} \mathrm{n}^{1}$ at two densities. Since no data were found for $\mathrm{LI}_{2} \mathrm{SHO}_{3}$ and $\mathrm{L} 1 \mathrm{AlO} \mathrm{O}_{3}$, data for other silicates and aluminates are shown. 2 "In the present analyses, the theras 1 conductivities of the two complex oxides are anaumed to be similar to that of $\mathrm{LI}_{2} \mathrm{O}$. As indicated by the results, the thermal conductivity is sigaificantly affected by the density and, in general, 1o quite 10 for these ceramics.

\section{Neutronics Properties}

Two neutronics charecteristice of the soldd breeding materials have been evaluated, v12., breeding capability and long-lived activation products. Since the breading capability or breeding ratio is scnative to the apecific design detalls, only a general asuearment 1s prasented here. The $\mathrm{LI}_{7} \mathrm{~Pb}_{2}$ ponessea very good breeding characteristics because of the neutron multiplication provided by the lead. The $\mathrm{LI}_{2} \mathrm{O}$ has an 1nherently high lithium atom density; however, thia advantage 1s somewhat reduced since the actual wa-
terial used way contain $20 \%$ porosity. Also, the effective breeding capsbility of the ceranics is inpacted by the relatively high structural material fraction required because of the $10 \mathrm{~d}$ tharmal conductivity. It Is generally concluded that $\mathrm{LI}_{2} \mathrm{SiO}_{3}$ and $\mathrm{L}_{\mathrm{AAlO}}$ will requira a neutron multiplier to obtain adequate breeding because of the parasitic absorption of the other elementa present.

of the candidate breeding anterials, only $205_{\mathrm{Pb}}$ frow $\mathrm{LI}_{7} \mathrm{Fb}_{2}$ and $26_{\mathrm{Al}}$ from $\mathrm{L} \mathrm{ANIO}_{2}$ preaent long-ter activation probleas unlese aignificant anounts of Impurition are present.

\section{Cheical Stability and Coapat ib1lity}

The chenteal stability and coupatibility of the nolld coupounde in the reactor anviroment are inportant conalderations in the selection of the wout riable options. Water and hellun are the priae cand1date coolnate for use with solid breeding wateriale since lithlum would noat likely be uead at the breedins aterial if it were selected a the coolant. The ninor consideration reterdins a watar-coolad blanket relates to the fact thet $a 11$ of the candidete breedins anterials react to some. degrea with $\mathrm{H}_{2} \mathrm{O}$.

\footnotetext{
Work eupported by the U.8. Department of Eneroy.
} 
Table 1. Suary of Propert 1ec of Candidate Breedige Materiale

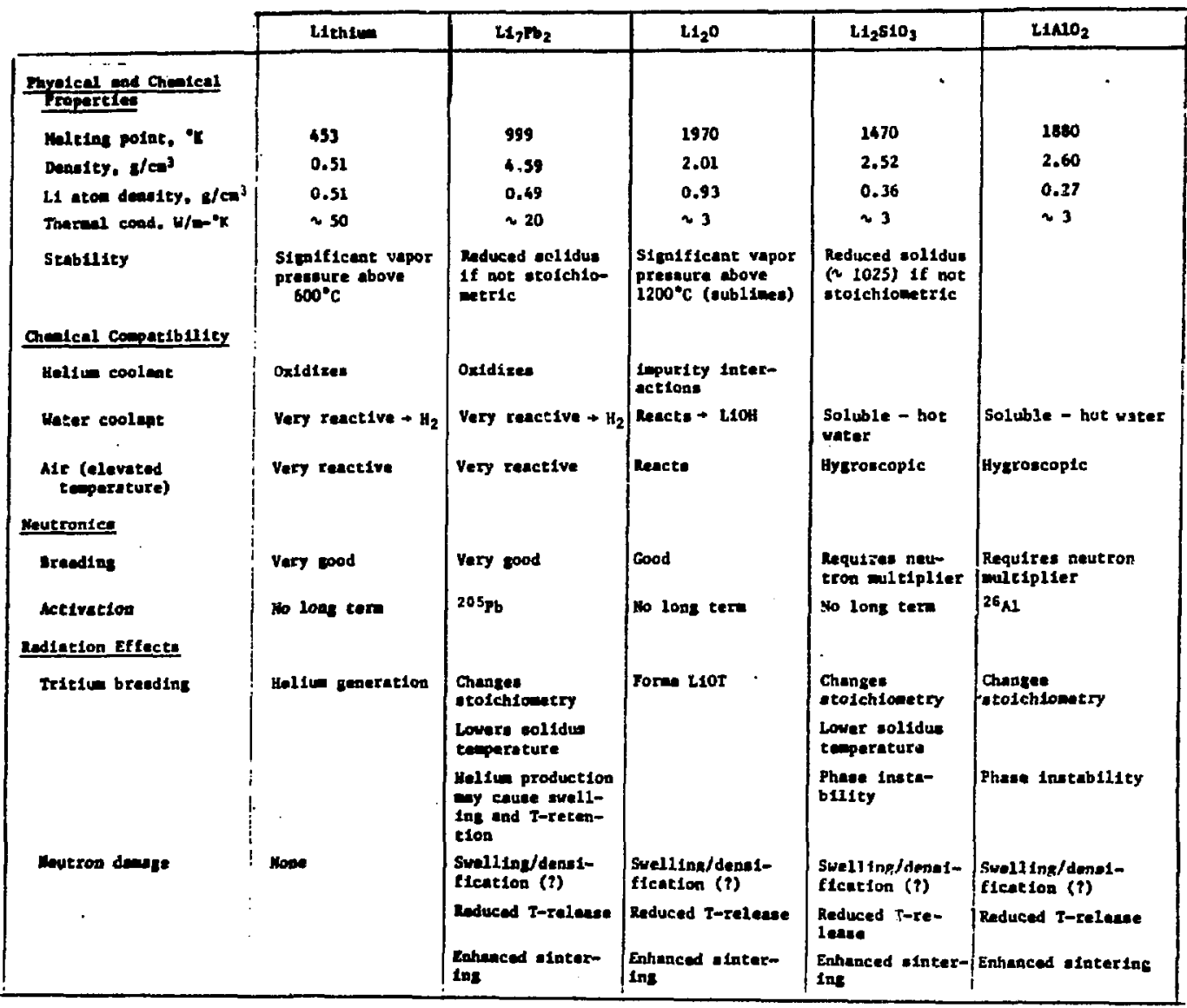

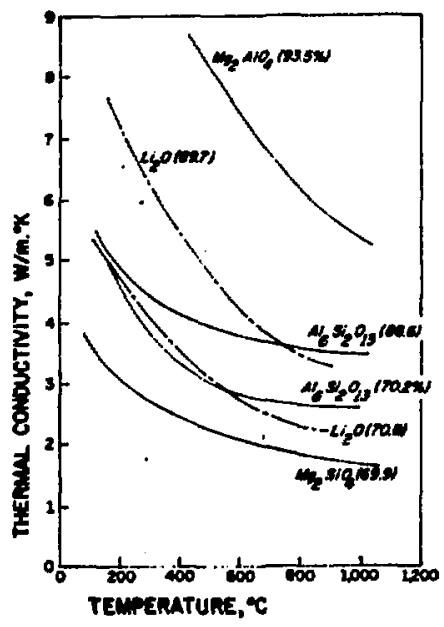

11\%. 1. Therel concuctivities of oxides with offective deneities given in parentheses.
The following hydrolyale reactions will occur on contect of vater w1th $\mathrm{LI}_{7} \mathrm{Hb}_{2}$ and $\mathrm{LI}_{2} \mathrm{O}$.

$$
\begin{aligned}
& 1 / 7 \mathrm{LI}_{7} \mathrm{Fb}_{2}+\mathrm{H}_{2} \mathrm{O}+\mathrm{LIOH}+1 / 2 \mathrm{H}_{2}+2 / 7 \mathrm{~Pb} \\
& \Delta \mathrm{R}_{\mathrm{hrd}}\left(298^{\circ} \mathrm{x}\right)=-47.9 \mathrm{Kcal} / \mathrm{mole} \\
& 1 / 2 \mathrm{LI}_{2} \mathrm{O}+1 / 2 \mathrm{H}_{2} \mathrm{O}+\mathrm{L} \mathrm{LOB} \\
& \Delta \mathrm{A}_{\text {hyd }}\left(298^{\circ} \mathrm{K}\right)=-15.4 \mathrm{Kcal} / \mathrm{sole}
\end{aligned}
$$

Both of these compounde react exothermically with weter to form L10H whlch has a xeltias teaperature of $470^{\circ} \mathrm{C}$. Since 11quid LiOH 1o extrebely corrosive to mar1y all etructural meterdels, the Integrity of the etructure vould be severely detraded in the eveat of a reaction that forn LiOH. In addition, hrdrogen forind is the reaction of $\mathrm{H}_{2} \mathrm{O}$ with $\mathrm{LL}_{7} \mathrm{~Pb}_{2}$ presents a eafaty probles which probably elininates this oyoten a a viable blanket option. The reaction of $\mathrm{LI}_{2} \mathrm{O}$ with water 10 coantderubly lese exothernic and, elnce hydrogen Ie not evolved, this reaction does not pose a esjor eatety proble. Ne thown in F1g. 2, the free cuargy of the $\mathrm{LI}_{2} \mathrm{O}$ reaction decreaces to zero at $\sim 1200^{\circ} \mathrm{K}$, which Indicates that the rastion should stop at the 


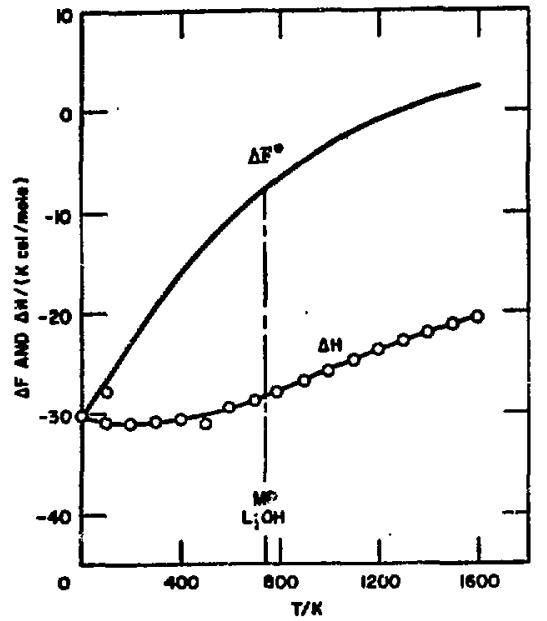

F1g. 2. Tharmodynamics of the reaction $\mathrm{LI}_{2} \mathrm{O}$ (C) $+\mathrm{H}_{2} \mathrm{O}$ (s) $\neq 2$ L10H (C or $\ell$ )

tempexacure 1s Increased. The reactions of $\mathrm{H}_{2} \mathrm{O}$ with $\mathrm{LI}_{2} \mathrm{SHO}_{3}$ and $\mathrm{LAAlO}_{2}$ are even less severe. The $\mathrm{LI}_{2} \mathrm{SHO}_{3}$ will decompose in hot water and probably form some bydroxide. Although data are 1 inited, $\mathrm{LLIO}_{2}$ appears to be more stable than the silicate.

Although holium 1s chemically inext to the cand1date breeding waterials, trace 1mpurities typical of large heat-tranoport aystems can react. The $\mathrm{Ll}_{7} \mathrm{~Pb}_{2}$ wili react with minute levels of oxygen in hellum to forn an oxide fil that will inhibit tritium releage. Subsequent changes in stoichlometry of the breeding interfal caused by oxidation of the lithiun will lower the alting temperature of the system.

Under certain conditions, trace amounts of water vapor in hellun will react with $\mathrm{LI}_{2} \mathrm{O}$ to form soldd or 1iquid L10A. Figure 3 10 a plot of the calculated $\mathrm{L}_{2} \mathrm{O} / \mathrm{LIOH}$ phase equilibria al a function of $\mathrm{P}_{\mathrm{H}_{2} \mathrm{O}}$ and temparature. The shaded region indicates the cond1tLon onticipated in a fusion reactor environeent. At the lower temperatures and higher water-vapor prespures, formation of $\mathrm{LHOH}$ is predicted. Further calculations Indicate that the vapor presnure of I1ad over $\mathrm{LI}_{2} \mathrm{O}$ is a igaif $1 \mathrm{cant}$ at temperatures of > $1000^{\circ} \mathrm{K}$ if water vapor 18 present. Experisental reulte in Table 2, which were reported by A. Johneon, et al. 3 tend to support the calculations. These reaules how significant welght losese of $\mathrm{LI}_{2} \mathrm{O}$ when aponed to $1270^{\circ} \mathrm{K}$ to $10 \mathrm{w}$ water-vapor prasmuren. At vater-7apor pressures required to malntaln low tritlum presenses, 1.a., 0.01 to $1 \mathrm{~Pa}$, the walght lobeen are axceselve and diract contect of hellue coolent with $\mathrm{Li}_{2} \mathrm{O}$ is not conoldered acceptable at the higher temeraturee. Although $\mathrm{LI}_{2} \mathrm{SHO}_{3}$ and $\mathrm{LLNlO}_{2}$ are leas arceptible to this reaction, the present data base is Insufficient for a raliable evaluation of the proble.

The date are aleo very linfted on the conpatibility of the cendidate colid breading materiale with potential etructure or cleddine meteriale. Racent

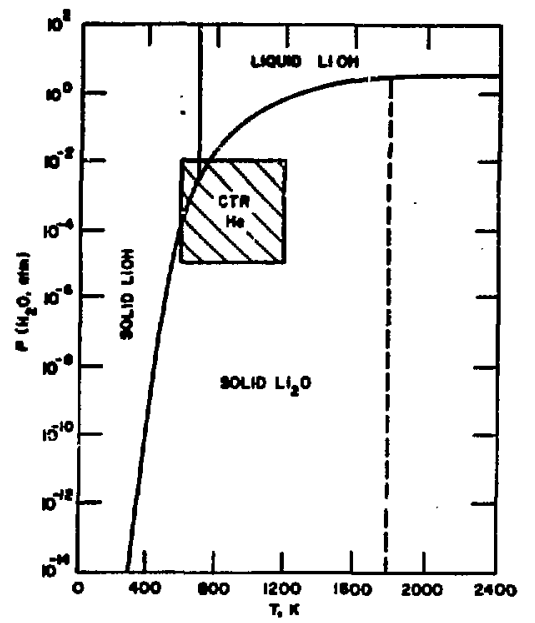

F18. 3. Calculated $\mathrm{Lt}_{2} \mathrm{O} / \mathrm{LIOH}$ phase equilibria as a function of $\mathrm{P}_{\mathrm{H}_{2} \mathrm{O}}$ and tenperature.

Table 2. Whetgh Loss of $\mathrm{Li}_{2} \mathrm{O}$ Expcsed at $1000^{\circ} \mathrm{C}$ to Low Water-Vapor Pressures

\begin{tabular}{ccc}
\hline $\begin{array}{c}\mathrm{P}_{2} \mathrm{O} \\
\mathrm{Pa}\end{array}$ & Expoure Time & Weight Loes \\
\hline Eracuation & 2.5 & $\mathrm{Z}$ \\
$10^{-5}$ & 2 & 3.3 \\
$10^{-2}$ & 2.5 & 3.2 \\
$10^{0}$ & 2.0 & 6.4 \\
$10^{2}$ & 0.5 & 12.4 \\
\hline
\end{tabular}

data ${ }^{4}$ on the compatibility of $\mathrm{L}_{2} \mathrm{O}$ with Fo-N1-Cx lloye ore given in FIg. 4. Thase corroston rated are wuch higher than typical corrosion ratee of atainlese teel in reactor grade sodtum and are probably excensive at temperatures above $\sim 500^{\circ} \mathrm{C}$. Anothar corrosion proble of concern relates to the formation of Liok as discuseed above or Lior from the braeding reaction. The Liob is highly corrosive to most structural anteriale and could present probleme in the bat tranoport or tritiue procaselng circuite.

\section{Tritiun Roleace fron Solld Braeding Materlale}

For col1d brecdere, tritiue wot 11kely will be recoveted as $\mathrm{T}_{2} \mathrm{O}$ from a hellu purge atres by corption on eolecular afeves. The tritium invantory in the colld brueder will be deternined by both diffunton raten and thernodyneate conetrainta. 


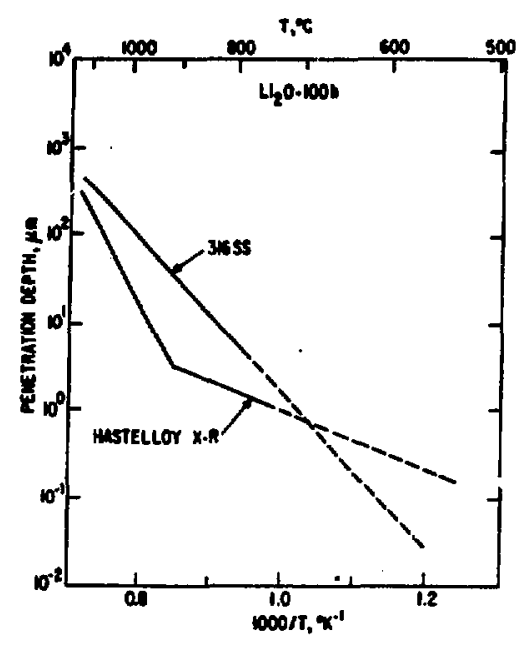

E18. 4. Corrosion of atructural alloys exposed to $\mathrm{x}_{1} \mathrm{I}_{2} \mathrm{O}$ for $100 \mathrm{~h}$.

\section{Diffugion Considerations}

In a fusion blanket, the tritiu concentration in the solld breeder w1ll bulld up untll the rate of diffunion out of the solid is equal to the sritism generstion rate, and ateady state is ach1eyed. For infinite slab geowetry with zero aurface concentration, the oteady etate relationship is described by

$$
I=\frac{1}{3} \frac{r^{2}}{D}
$$

where I - tritium inventory $(g)$,

I - tritium generation rate $(\mathrm{g} / \mathrm{s})$,

$r$ - half-thickness of the elsb, and

D = diffusivity.

- In typical experimente, 5 when diffusion rates are neanured by first 1rradiating the anple and then hesting to reove tritium, the diffusion kineticu are not ateady atsie. The steady state diffusivity, which w11 give a conervative eatimate of the tritium inventory, is given by

$$
p=\frac{r^{2}}{15 t}
$$

were $\tau$ - man residence time for tritiun in solld, 1.e., the tile to extract 87.47 of the tritiun.

In the experiment, $T$ can be readily manered; but, 1t 1t much more difficult to deterwine $r$, and therefore, $D$ : However, assuning the $r$ in the experinent: 1s representative of material in a reactor blanket, equations (1) and (2) can be conbfined to elininate $r$ and $D$. The trittum inventory 1s then given by

$$
\mathbf{I}=\mathbf{s} \mathbf{I} \boldsymbol{\tau} \text {. }
$$

For a 1000 with renctor (ateady stete) at 20 kV/fusion and a breedifge ratio of 1.20 , the tritfun generation rate (I) $101.87 \times 10^{-3} \mathrm{~g} / \mathrm{s}$. If r 1s expreseed in hours, then

$$
I(s)=33.6 \cdot \tau(h)
$$

Deing this ralationship, the calculated tritiwn Inventortes for candidate solid breedere are show in P18. 5. In view of the very atrong temperature dependence and the fact that the inventory in extremely enattive to the diffusion path length $r$ (I = $r^{2}$ ), 1t is not surprisins that some analyess coaclude that solid will have very low tritiue inventor1en, while others conclude that solide may have very high inventories.

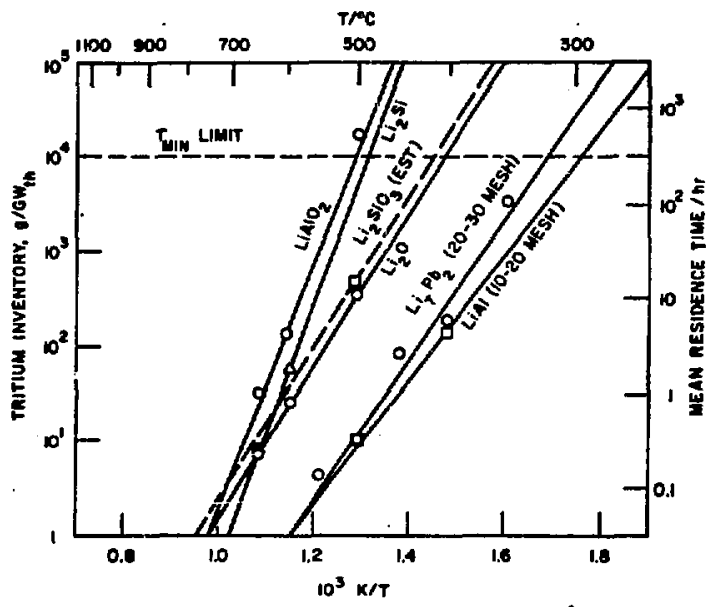

F1g. 5. Predicted tritium Inventory in candidate solid breeding materials (20 mesh) as a Function of temperature after low-fluence irradiation.

The design molution to this dileme is proper teaperature control. The minimum temperature must be afficiently high that teitium will diffuse out at an adequate rate, and the maximum temperature must not peruit exceastve agglomeration and ointering, which could Increase the diffusion path length and thereby reduce diffuaion rates. It is suggested that, as a dealgn criterion, the inventory of any $5 \%$ of the blanket not exceed $500 \mathrm{~g}$ per GWh. Therefore, on the bag1s of thermal diffusion, not wore than $5 \%$ of the blanket can be below the minimum temparatures Indicated in Fig. 5. These minimum temperatures are given In Table 3 for the same breeding materiala. Increasee in particle size caused by thermal sintering will tend to Inhlbit tritius release. Estimated temperatures below which thermal alntering yill not be important are given in Table 3. Wiswall 5 performed prolonged hat treatmenta on several materials at $80-$ to $90 \%$ of the abeolute melting temperature and obaerved only linited structural changea.

It is expected that the radiation environment way hive some effect on the tritlun release cheracteriecics. Radiation-induced trapping of colutes has been obeerved in Irrudiated materials. Wiswall obearved that tritiua relenes rates from certain oxides decreased with increasing fluences (up to $10^{20}$ $\left.\mathrm{n} / \mathrm{cm}^{2}\right)$. Fipure 6 showe the offect of neutron fluence on the trition ralease characterlatics of $\mathrm{LHAlO}_{2}$ at $650^{\circ} \mathrm{C}$. At the higher flueaces the fractional release uader ofintler condition. 1a reduced by about on order

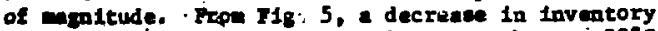
by an order of apritude translates th about i $50^{\circ} \mathrm{C}$ increace in temperature. Tharefore, oinime release coperatures under Irradiation are increased as Ind1cated in rable 3. The effects of radiation-induced 
Table 3. Toperature Lifite ( ${ }^{\circ} \mathrm{C}$ ) for Solid Breeders

\begin{tabular}{|c|c|c|c|c|c|}
\hline \multirow[b]{2}{*}{ Dremer } & \multirow[b]{2}{*}{ n.p. "c } & \multicolumn{2}{|c|}{ Donel Itfoet: } & \multicolumn{2}{|c|}{ Maldation Efecere } \\
\hline & & $x_{\text {ate }}{ }^{2}$ & $\tau_{\max }^{2}$ & $I_{01 n^{3}}{ }^{3}$ & $t^{2}$ \\
\hline$L 1 \mathbf{2}^{\circ}$ & $1700^{3}$ & $\$ 20$ & 1000 & 160 & 910 \\
\hline $\mathrm{LMO}_{2}$ & 1610 & 500 & 1000 & 590 & sso \\
\hline$L 1_{2} 8 \pm 0_{3}$ & $1200^{6}$ & 420 & 900 & 670 & 620 \\
\hline $21_{2} 51$ & 700 & 460 & 350 & $\mathbf{5 3 0}$ & 420 \\
\hline Lwet & 100 & 300 & 900 & 350 & 300 \\
\hline Lt, & 726 & 320 & 530 & 370 & 390 \\
\hline
\end{tabular}

1 Diffurion linited.

2 Theral sintering.

3 Redintion-tnduced trapping (factor of 10 degradation in tritium release estimated).

4 Radiation enhanced aintering $\left(0.6 \mathrm{~T}_{\mathrm{m}}\right.$ for oxides and $0.67 \mathrm{~T}$ for other compounds). $\mathrm{LI}_{2} \mathrm{O}$ reportedly sublimes at temperaturea below the aelting point.

$\mathrm{II}_{2} \mathrm{SIO}_{3}$ is a 1 ine compound with a solidue temperature of $\sim 1030^{\circ} \mathrm{C}$ for slightly hypo- or byperetolchiometric coupositions.

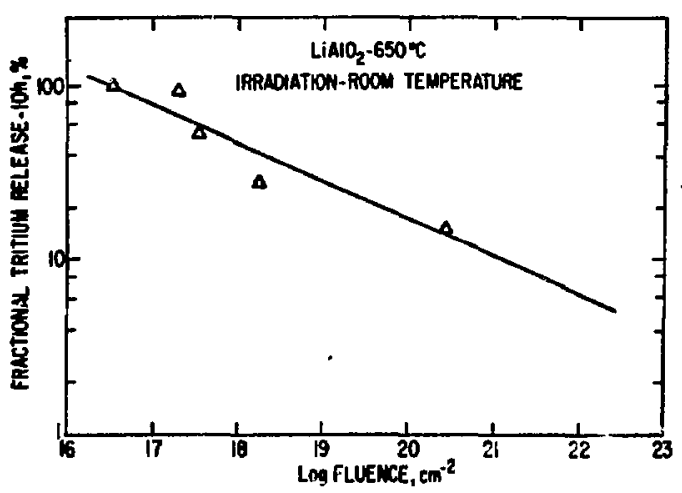

7ig. 6. Effect of neutron fluence on the tritium releane characteristice of $\mathrm{LHLO}_{2}$ at $650^{\circ} \mathrm{C}$.

aintering are aleo conolderad. The anxime sllowble teoperature for ceranice is entinated from revulte on oxide fuels in tission renctors, wheretn radiationcahenced sintering occura at 20.6 of the sbsolute ealting temporature. For the setallic conpounds, the rediation sintering terperature 1o ascuned to be $2 / 3$ of the abcolute melting teporature.

Frovided the breeding sater 1als are maintained wthin the liated teaparature conatrainta, the astianted tritiun holdup by diffunion will be lass than $1 \mathrm{~kg} /$ Gith. It 1a evident that the cerantc breeding arerinis provide the lergat operating temperature ranges. Of the three ceranics, $\mathrm{LI}_{2} \mathrm{O}$ appeare to be the wost favorable.

\section{Thernodynule Considerationg}

The tritiu release and recovery characteristic. are also affected by thermodynimic constderations. Since experimental results on the phase equilibria are limited, the following calculational epproach has been used to evaluate this effect. The vapor phase composition above $\mathrm{LI}_{2} \mathrm{O}$ was calculated using the avaflable therwochemical data. ${ }^{6}$ The tritium is assumed to be present as LIOT in Ideal solid solution $\mathrm{In} \mathrm{LI}_{2} \mathrm{O}$. The tritium content of the $\mathrm{LI}_{2} \mathrm{O}$ was taken to be 1.0 uppe (mole fraction $=1 \times 10^{-5}$ ) and the mole fraction of $\mathrm{H}(\mathrm{a} \mathrm{L1OH})$ in $\mathrm{Li}_{2} \mathrm{O}$ was assuned to be $1 \times 10^{-3}$. The relevant equilibria are:

$$
\begin{aligned}
& 2 L 10 T(c) \neq L_{1} O(c)+T_{2} O(g) \\
& L 1 O H(c)+L L_{10 T}(c) \neq L 1_{2} O(c)+H T O(g) \\
& 2 L 1 O H(c) \neq L 1_{2} O(c)+H_{2} O(g)
\end{aligned}
$$

Roult's Law was used to estimate L1OH and L1OT vapor pressurea. Accordingly, the calculated vapor phase compositions are shown in Fig. 7. At $800^{\circ} \mathrm{K}$, the HTO prssisure is $10^{-6}$ torr and the $i_{2} 0$ pressure 1s $10^{-8}$ torr. From mass transfer considerations, a $\mathrm{T}_{2} \mathrm{O}$ (or HTO) pressure of about $10^{-3}$ torx is required in the purge stream, in order to remove the tritium at reasonable purge flow rates. It appears that the tritium concentration in the solid $\mathrm{LI}_{2} \mathrm{O}$ would have to be increased to $\sim 300$ wppm in order to effectively reccver tritium by a purge stream. This would correspond to a tritlun Inventory of about $40 \mathrm{~kg}$ per GWth. The compound $\mathrm{LANIO}_{2}$ and $\mathrm{L}_{2} \mathrm{SHO}_{3}$ are expected to have ignificantly higher $\mathrm{T}_{2} \mathrm{O}$ vapor presaures, and hence, lower Inventorles. Additional data are required to relinbly deternine these values.

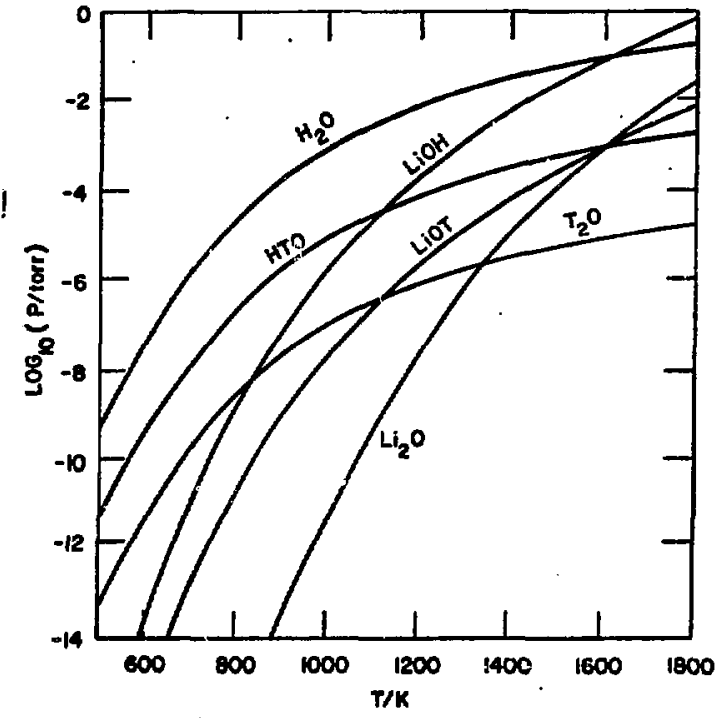

F1s. 7. Vapor phese epecien in equilibrtun with $\mathrm{L}_{2} \mathrm{O}$. 


\section{Concluetone}

The wajor design probleas ragarding the une of coled breeding antertals In fusion reactor blanket: relate to the capability to resove tritiu from the wold. The temperature uindow for trittus relese appeare to be acceptable only for the cerantca. Of che caralcs, $\mathrm{LI}_{2} \mathrm{O}$ hes the largest temperature range. Bowner, thermodynamic calculations indicate that the eritiun concentration in $\mathrm{L}_{2} \mathrm{O}$ ac enticipated $\mathrm{T}_{2} \mathrm{O}$ preseures will be greater than $10 \mathrm{~kg} / \mathrm{GWth}$. The correspond $I_{8} \mathrm{~T}_{2} \mathrm{O}$ pressures over $\mathrm{LI}_{2} \mathrm{~S}_{10}$ and $\mathrm{LAAlO} \mathrm{O}_{2}$ are higher, and therefore, lower tritfum concentrations in these oolids wy be attainable. Additional therwodynalc data are required to more accurately deternine the tritlue holdup in solid breeders.

\section{References}

1. T. Takahashi, et al, (to be published).

2. I. E. Compbe11, High Temperature Technology, John H1ley and Sons, New York (1956).

3. A. B. Johnson, T. J. Kabele, and W. E. Gurwell, "Tritium Production from Solid Targeta," Batteile Paclfic Northwest Laboratory, BNWL-2097 (1976).

4. T. Kurasawa, et al., "Reaction of Several Iron and Mickel Based Alloys with Sintered $\mathrm{L1}_{2} \mathrm{O}$ Pellete," J. Nucl. Hater. 80,48 (1979).

5. R. Wianll and E. Wirsing, "The Removal of Tritium fron Fuston Reactor Blankets," Brookhaven Hational Leboratory, BNL -50748 (1977).

6. JMHP Thernochenical Tables, Dos Chemical Co. MIdIand, KI, 1971 and 1974. 


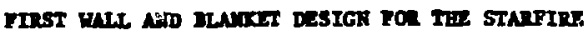

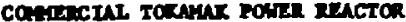

by

G. D. Morgen, C. A. Trachee1, D. A. Cremar, D. A. Lowera McDonneli Dousles Astroneutica Co.. St. Loule, Mo.

and

Dele L. SAtth

Argone National Laboratory, Argoun, II.

The first well and blanket denisn concepte beins evaluated for the sTARrine comerctal tohmak reactor etudy are presented. The two concipte represent different approaches to the Eachnicel deeign of a tritiu breeding blenket ueins the referance anterial. options. Eech concept hes a oparate ferritic ateel firat well cooled by heary water $\left(\mathrm{D}_{2} \mathrm{O}\right)$, end a farritic ateel

blanket wth oolld 11tblue oxide breeder cooled by helium. A separate heliu purze systen is uned in both concepts to extract tritiu. The two concepts are comared end relative edvanteges and disadvantagee for escb are discussed.

\section{Introduction}

F1rst wall and blanket wechanienl desien optlone are beins developed for the wiected reference anterials option. The rationale for the natertale election is the wubject of a separate paper ${ }^{1}$ at this symposiun and w1ll not be diecuased here. The table belov briefly sumarizen the selected materiale.

\section{Firat Wall}

Structure: Ferritic atenl (Alternate: AutenIt1c stainless eteel)

Coolant: $\mathrm{D}_{2} \mathrm{O}$, heary water

Blanket

Structure: Ferritic oteel (Alternates: TitanIun alloy or austenitic stainless gteel)

Coolent: Heliu

Dreeder: Lithiue oxide

Two different echanicel design concepte for the reference mteriala option are presently beins developed and further andyzed to ascure that denton requirements are entiofied in the arese of thninal hydraulice, power cycle efficiency, tritiu bresdios. tritive recovery, fabricability, and atructurel interrity. The concepte will swo ba compred to deternine how well they antiefy. these importent sTauries dealen objectIven:

- Antinize probebility/congequences of accidantel contact of incopatible eateriale;

- vaxinise rellability of ayated and componente, to Increana evallabllity:

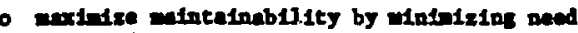
for, and tin required for, atandard anintenunce operation:

- Dinintes Imar mil/blaricet/ehteld thicheas $\left(\Delta_{y s}^{1}\right)$, to reduce resctor atre and noxtmon anpette flald; and
- EIninize outer vall/blanket/ohteld thickneas, to eininize TF and $E F$ cot1 ise.

The final cholce for the rechanicel desien concept w11 be ande following there enelyaes and comperisons.

Selection of the wechnnical design concept for the helium cooled blanket is atrongly dependent on the Individunl and conbined characteristics of the selected etructural anterial, coolant and breeder. of critical inportance is assuring satisfactory adherence to einimin end maxtme temerature constraints placed on the wolid breedern ${ }^{1}$. Hininizing the blanket thickness, mentfold end header size are also of mujor teportance, in order to Intaize required reactor o1ze.

Both the design concepts being evaluated use the appronch of ind Ividunl blanket sodules of sinilar shape end size which are built up Into wedge-shped first wall and blenket clrcuferential sectors. Th1s

epproach, discussed in another peper at this Symposine, has several dvantages. It pernits more eccurate talloring of the blenket to match nestron wall loxd values at specific positions around the plasw cross section. Accomodation of local discontimitied such at vaculin ports and $\mathrm{rf}$ ducts is simp1ified. Replacecont of Individual modules can be perfornd in the hot cell, wile the reactor continues nornal operntion following inatallation of a replacenent sector. The reactor in thus ahut down only for the time needed to remove the oector containing a faulty first wall or blanket component and to laste1l the replacement sector.

A weter-cooled first well, achantcally and atructurally eparate fron the blenket, was selected for both the blanicet dagign concept:. The eeparate firat wall concept parnita ainple replacenent (in the hot cel1) of a falled firat wil panel without aleo requirins replacesent of the ore expennive blankst module behind It. The use of vater coolent for the firet wall in the reference design accomodnten the enlected noutron wail land $\left(P_{m}\right)$ value of $3.5 \mathrm{w} / \mathrm{e}^{2}$ with negilgible pupins loases. The two additional dieconnect/reconnect: operatione for the firat well weter coolant headere, necessary for removel of a blanket anctor, are not conaldered a major addition to the tine required for that operetion.

\section{Diecuieton of Denter Coscepte}

Two technical donien concepts are being conoldarad for the blanket. In the firat concept, the nodule well. are prasaur1zed to the coolent etatic presaure. The colld bresder is contalned in weled tubes, arransad in a utagered rod benk pattarn, which are cooled by crose-flowint the bellu over then. In the encond concapt, the helilu coolant flowe Inelde tubes each of whish is surrounded throushout the sodule by the colid breader. This anction diacuanes the two concepte, and tise vater-cooled firat well conen. to both. 


\section{Precurticed rodule Coscept}

The preanrized blankat eodule hes cacentially the forw of a elightly tepered parellelepiped, as ehown in 718. 1. Four of the aldes are aligned to follow the two plane forned by the udge-chaped blartet ector and two planee extending redially, from approxingtely the plase center. The front face is evictrcular and the back face 10 a shallow sentellipsold. Hodule width (distmes slons sector chord) 1o variable to sateh uector width at any point. Module depth and thernal hydraulic paranters (braeder zone detalle and coolnet ane flowrate) any be adjusted to wech the actual neutron well load for any position in the blanket sector.
Tech module has one coolent inlet and two coolant outlece at tive rear fece, whtch etcech to malfolds rreppise around the blanicat ector. The nenifolds conect all wodules in the eector together and rum to vertically eligned haders (1aree diecuter pipea) at the top and botten of the enetor. The hadere are nechentenlls atteched to inlot ad outlet feed pipes wich reasil in the reactor when a eactur is remored.

Beliv coolent entera the odule through the inlet at the ranr face and flows redially tourat the front face (nose) through plenues forned by the double wild nodule sides. The helium enters the semicircular noes aren there the flow is divided into chnmele rith flow direction alternatins between adjacent

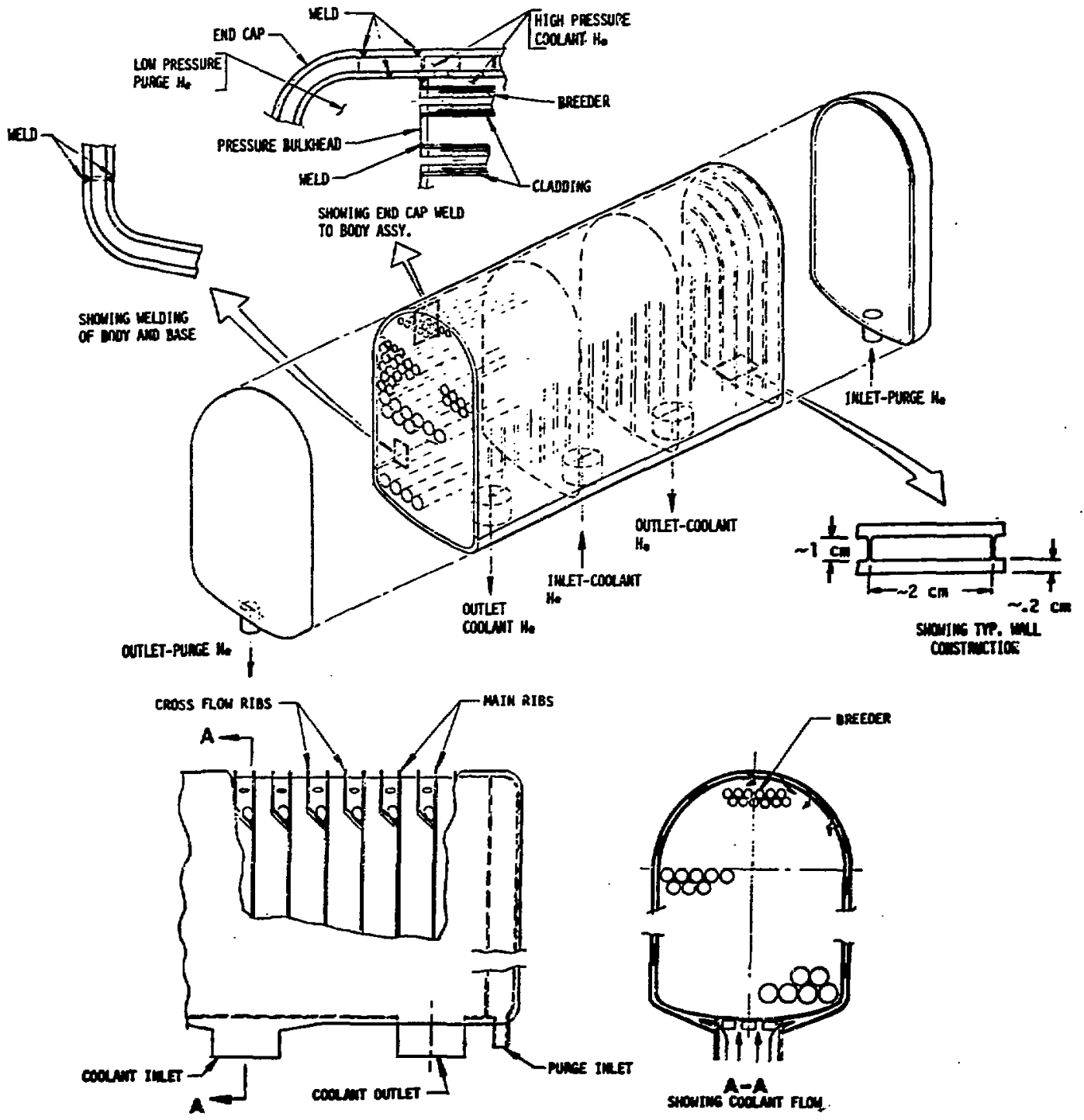

Figura 1. Beliu-Cooled Blenket - Preseurised, Module Concept. 
chennel. The beliue then enters a plexin region through ports in the nose inner wall and flowe radially through the breedins resion. The flow then enters a second plente rezton and exits to the outlet manifolds.

The breeding zone of the preseur 1zed wodtile contalns circular breeder tubes, which extend across the full module width (toroldal direction). The tubes are in rows, with succesalve rows otaggered to produce an equilateral pitch. Bach tube cons1ate of a structural shell, $\mathrm{L}_{2} \mathrm{O}$ breeder, and and fittinge for the purge gat oystes. The whell in aled for a differential preacure (collepse) equal to the coolent atutic pressure. The coupacted 11thiu oxide breeder Inolde the shell has a anall central wial hole. The purge ges is introduced into the cell through the fittins at one end, flows through the breeder center hole, and exits through the fltting at the other ead. The hellun (at $\sim 1$ atw pressure) permeates the breader, and collects the tritiun in the form of $T_{2} O$ or Lior with oxygen supplied through a low partial pressure of oxygen in the hellum.

The breeder tube dianeter varied through the depth of the blanket, fron $\sim 1.8 \mathrm{cn}$ near the nose to $\sim 4.0 \mathrm{~cm}$ the renr, in order to malntaln breeder temperetures within minimu and naximu temparare infte ${ }^{l}$ as volunetric heating retes decrease with depth through she blanket. The breeder temperaturea are ensitive to changes in the heat conductance velue (essuned to be $\sim U=2000 \mathrm{H} / \mathrm{E}^{2}-{ }^{*} \mathrm{~K}$ ) for the structure/breeder interface. Further work is needed to optinize breeder tube design detalla to assure that required valuee of conductance can be reliably mintained throughout the blanket design 11fe.

Heat generated within the breeder is conducted through the breeder to the tube structure surface. The helium coolant, flowing ecrose the rous of tubes, renoves this heat by convection. Theresl-hydraulic characteristics of the coolant flow across the breeder tubes are based on well-establiahed expirical reletionshtps for crose-flow tube bank heet exchangers. Spacing of the tuben is based on an equilateral pattern for adjacent tubes with $1.15 \mathrm{D}$ apacing between tube centers (1.e.. the gap between any two adjacent tuber 1s equal to 0.15 times the tube dimeter). This per1ts a relatively high packing fraction for the tubes. Total punplng power required for the breeding zone only is 20.5 kM (puep work) for the reactor, which is negligible in compariacn to the power required for the rest of the hellu coolant eyoten. Total purping power for all 24 blanket sectors is eatineted to be $250 \mathrm{HH}$ (pump work), or $\sim 1.37$ of total reactor theral power with nearly all the losses occurring in the andfolds. This value Includes all pressure lossee occurring in the aectors between the inlet and outlet hesder disconnects.

The pressurized nodule makes efficlent use of atructural sateriel to keep the structural volune fraction as low as possible in order to enhance tritilu breeding. The module oldes are desteped with outer and Inner walle jolned by ribs. Th1s design te structurelly wore efficient than a aingle pressurized wall. The we of two walle eleo provides a flow channel eround the blemket perfieter through which relatively cool heliv frow the inlet wasfold flowe radially towerd the blanket noes, keeplan all the preseuried outer well at $n 300^{\circ} \mathrm{C}$ or lene. The Imer walle experience virtully no differential preseure. Tle rode open the long width direction of the sodule in e squre pattern with $n 10 \mathrm{e}$ epecine. These rode react the preateure losd applied to opposite valle, further reducins the required wall thiclonese. In the short width direction, a cembinntion of tie rods and thin bulkheads 10 used to resct preserure loede on opposite walle. The bulkbeds 100 provide support for the lon breadis celle by boldin then in close-fitting boles to prevent ary oignificunt daflection of breader tubes betwes bulkhesdy. The poesibility of ualos the breader tubes ae atruetural mobera, to elininate tia rods in the lons width (tube axiei) direction, w11 be Imvestigated.

Coolant inlet terperature and outlet fenperature for the presentized wodule concept are $250^{\circ} \mathrm{C}$ and $500^{\circ} \mathrm{C}$, respectively. A kes feature of this concept is that it perite the axime coolent temperature to be approulmetely equal to the maximun teperature of the Iodule w11 otructure. Th1s is inportant becewe it nexinfes the power cycle efficiency for the heliu coolent. The only highly preseurized atructure in the module with a tesperature nearly equal to coolent outlet teaperature 10 the outlet anifolds at the rear of the blanket. All other etructure in the vodule, with the exception of the breeder tubes near the rear of the blanket, will experience temeretures no sreeter than the coolent outlet tenperature. The breeder tubee near the rear of the blanket are astimated to have a atructural texperature approrimtaly $30^{\circ} \mathrm{C}$ higher than the local coolant, or $2530^{\circ} \mathrm{C}$. Host of the etructure will be at con-iderably lower tenperatures, and w11 be slzed for loads resultins from thermal gradiente and reactions to presnure loada.

The pressurised oodule concept for the reference blanket has been analyzed to deternine a prelininary estiate for volve fractions, unlag both ferritic ateel elloy and titantue elloy TI-6242S ee etructure. The table below show the results.

\section{Ferritic T1-6242S}

$\begin{array}{lll}7 \text { V Structure } & 14.9 & 11.1 \\ 7 \vee \text { II }_{2} \text { G* } & 57.2 & 57.2 \\ 7 \text { V Vold/He } & 27.9 & 31.7\end{array}$

* Volune required by breeder without eccounting for volds.

The lower structurel frection for the T1-6242S results fron the hishar allowable atreesee compared to tha ferritic steel. Fron the atendpoint of dasten and fabricabllity the titaniu allog eans auperfor to the ferritic eteel beceuve (a) 1ts duct1le-to-brittle trans1tion is eignificantly lese than roon conperature, (b) no preweld heat treatient is required, and (c) postweld heat treatsent (other then emealing) ie not required.

\section{Prescurised Tube Concept}

In the eecond concept for the belfu cooled blanket (F1g, 2), haliv coolant is conteined in tubes which are aurrouadad by the breeder (eesentially the reverue of the coacept previously described). The tubes are esch In a D-ohspe. The tube and restons are aligned redially dions the nodule ende, with the center region running lengthwiles through the sodule. The oode of the tubes are entfolded so thet each wodule hag only one inlet and one outlet fitting for the coolont. These fitting are located on the flat beck fecs of the wodule. The purze sas oyste consiat of a exparete natworle of porous tubes, each loented at the approselnate center of ary four edjecent tubes fording a square pattarn. The tabea are comected to a exparate header eyeten et the nadule anda which connect to 1nlet and outlet fittines at the rear face of the blanket. 


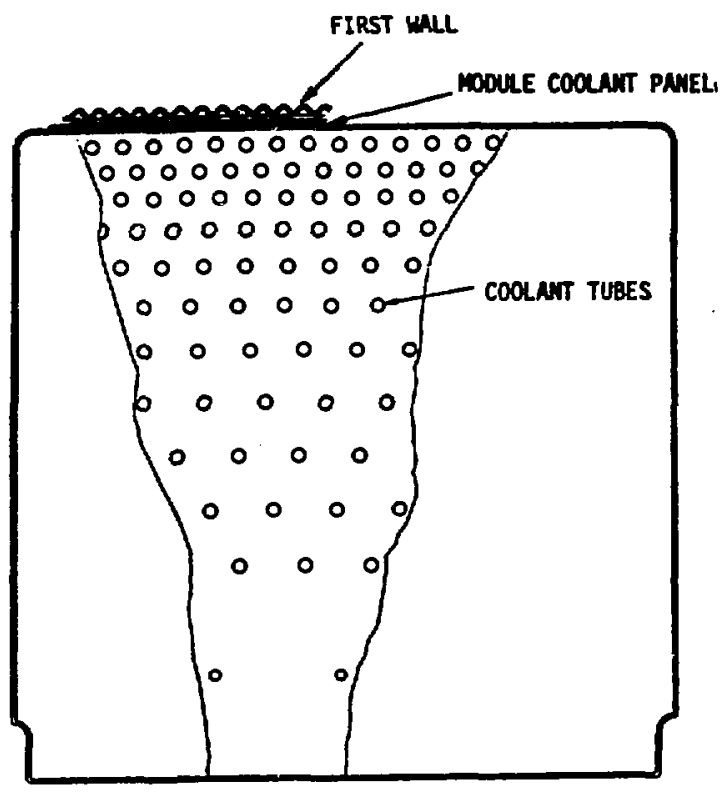

BLANKET CROSS SECTION

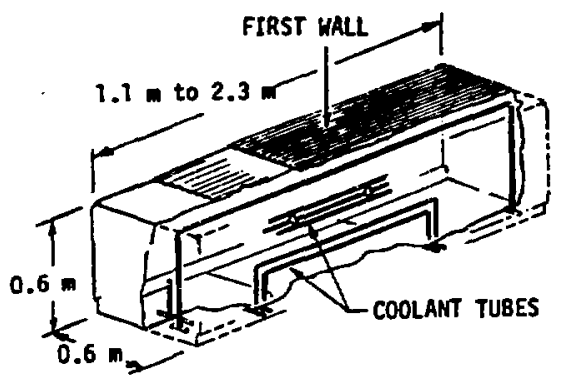

ISOHETRIC OF BLAMKET MODULE

F1gure 2. Heliun-Cooled Blanket - Pressurized Tube Concept.

The outer wall of the module is sized to conte1n the 21 ata atetic presoure of the heliu purge gan. The wall 1o actively cooled by heliw; conseruction is einilar to that of the water-cooled firat wall. Active cooling is conaldered necenanry becaue the breader conductivity is too 10 w to edequately cooduct bent eway from the outer wall to anintain a satiafactory nateve otructural temerature.

The nodule wall. enclose the breeder wich fille the sodule and surrouade the tublns netwoxk. Tube opacing, Inulde dianter, and length vary twough the blenket depth to achleve equel coolent thepratura changes and equal coolant preasure drope for all the tubes. Prelininary thatel-hydraulice anclyels indicetes that tube inolde dienters should wery froe $\sim 1.2 \mathrm{c}$ et the front to $\sim 0.8 \mathrm{a}$ et the rear of the blenket. Appraximately 170 tubes are required for each codule. I narrow gap between the breeder and the tube outer curface has been conearvatively seaved for heat trasefer calculatione. Coolant inlef and outlet terperatures have been asenued to be $225^{\circ}$ and $475^{\circ} \mathrm{C}$, reepectively. Outlet temerature was reduced from the $500^{\circ} \mathrm{C}$ asened for the previout concept to keep the nexile tube temperature to $\sim 530^{\circ} \mathrm{C}$. Preagure drope for the blenket have been estinated to be 16 to 18 pel at the 750 pais coolant static pressure. This result in punping pownr losses of $\sim 2 x$ of renctor thermal power.

\section{Immer Blanket Concept}

For botb concepte, the Inner blanket is preuent1y aweuned to be water-cooled and non-breedins, to mininize $\Delta_{B S}^{1}$. However, should neutroales analyate show that additional brzedins on the inboard wall in naeded for alther concept, a modified breeding blanket dests would be adopted for that region. The dealon would eecentially conetat of the firat 30 to 40 el depth of the atandard breeding blanket concept. Blaoket dapth and anifolding dimeter would be adjueted in this region to acintein the desired $\Delta_{B S}^{1}$ and atill achieve the necesary additional breeding and adequate heat recovery.

\section{F1rat Wall Concept}

The firat wil concept for the reference design is easentinlly a water-cooled flat panel. The basic concept is comon to both the reference and alternate blanket concepts. Dete1la of the design will be developed later in the study. For the present, the sechentcal deeign concept used 1s that adopted previously in the AIL-EPR study ${ }^{3}$. In this dealgn, cooling is accomplished by circulating pressurized water in a network of

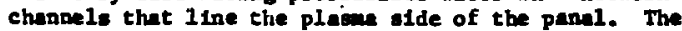
channele are formed by bondint preformed ateel sheet to a second, flat wteel sheet. Each panel section spans eaveral blanket sodules, and has one inlet and one outlet coolant line wheh connect to andfolds at the rear of the blanket nodule. These nanifolds connect all firet wall panels and the water-cooled inboard blanket within a angle blanket sector. The menifolda terminate in headers in the vicinity of the heliu blanket coolant headers, and are in turn atteched echunically to lulet and outlet feed pipes which rewin in the reactor when the aector is rewored.

\section{Conperieon of Bleniret Concepts}

Hgure 3 presents a comparison of the two blanket concepte previouly diecuesed in terme of design requirements and desien objectives. The preseurized tube concept has the relitive advantage of etructural einplicity compared to the preseruxired nodule coscept. The high preasure coolent is contained by tubes rather then by the Irregular shape forned by the epdule walls. The clrcular shope is atructurally sore effictont for containing tha hish presure. The raduction in the muber of atrase concentration realone could be capected to revult in wownat greater angurance aceatnet the occurrance of coolent lavis. Fabrication would be efplax for the preamurfaed tube concept, although the developent of a mekod to f1ll the sodule wth breeder to the dentred $60 \mathrm{x}$ of theoreticel denetty is - coxcerm.

bower, the preasurised tube coseept has amrial inberent relative diedvanteses. Fret, the mexilum terperature of each tube will be $\sim 40-50^{\circ} \mathrm{C}$ ebore the coolent outlet temexatre. The vall thicknemg of the 


\begin{tabular}{|c|c|c|c|}
\hline CATEGORY & $\begin{array}{c}\text { PRESSURIZED } \\
\text { MOUULE } \\
\text { CONAEPT (P-MOD) } \\
\end{array}$ & $\begin{array}{c}\text { PRESSURI ZED } \\
\text { TUBE } \\
\text { COMCEPT (P-TUBE) } \\
\end{array}$ & COMUENT \\
\hline \multicolumn{4}{|l|}{ DESIGN REQUIREMENTS } \\
\hline O THERMAL-HYDRAULICS & & & \\
\hline - COOLANT OUTLET TEMP. & f & & $\approx 40-50^{\circ} \mathrm{C}$ HIGHER FOR P-MOD \\
\hline - PIMPING POWER & l & & $\sim 1-2 x$ Masth) IN BLAKKET FOR P-TUBE \\
\hline - STRUCTURE TEMPERATURE & 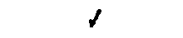 & & P-MOO WALLS COSLEO BY HELIUM TO $<300^{\circ} \mathrm{C}$ \\
\hline - POUER CYCLE EFFICIENCY & $f$ & & ح $2 \%$ HIGHER FOR P-MOO \\
\hline O TRITIUN BREEDING & -- & $f$ & LOWER VOIO FRACTIOH FOR P-TUBE \\
\hline O TRITIUH RECOVERY & $\ldots$ & $\cdots$ & ADEQUATE TRITIUN RELEASE FOR BOTH CONCEPTS \\
\hline - STRUCTURAL INTEGRITY & & 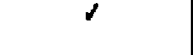 & $\begin{array}{l}\text { SIMPLICITY OF PRESSURIZED TUBES PARTLY OFF } \\
\text { SET BY MEED FOR ACTIVELY-COOLED MODULE WALL }\end{array}$ \\
\hline - FABRICABILITY & & $\checkmark$ & $\begin{array}{l}\text { SAME COMENT AS ABOVE; FILLING MODULE WITH } \\
\text { BREEDER WILL REQUIRE DEVELOPMENT PROGRAM }\end{array}$ \\
\hline \multicolumn{4}{|l|}{ DESIGH OB-JECTIVES } \\
\hline $\begin{array}{l}\text { MINIMIZE PROBABILITY/ } \\
\text { COHSEQUERICES OF ACCIOEHT }\end{array}$ & -- & $-\cdots$ & MO SIGNIFICAHT DIFFERENCE \\
\hline - MAXIMIZE RELIABILITY & & $f$ & $\begin{array}{l}\text { SIMPLICITY OF PRESSUAIZED TUBES PARTLY OFF- } \\
\text { SET BY NEED FOR ACTIVELY-COOLED WDDULE WALL }\end{array}$ \\
\hline - MAXIMIZE MAINTALNABIL ITY & $-=$ & $-\cdot$ & MO SIGHIFICAMT DIFFERENCE \\
\hline $\begin{array}{l}\text { - MINIMIZE FIRST WALL/ } \\
\text { BLANKET THICXNESS }\end{array}$ & & $f$ & $\begin{array}{l}\text { PRESSURIZED TUBE COHCEPT REDUCES TOTAL VOID } \\
\text { FRACTION IN BLANKET }\end{array}$ \\
\hline
\end{tabular}

$\checkmark$ = REL $A$ TIVE

ADVAIYTAGE

F1gure 3, Conparison of Hellum-Cooled Blanket Concepts.

tubes must therefore be s1zed to the maxima allowable atructure terperature and the coolnnt outlet temerature deterained accordingly. For the presurized nodule concept, naxim structure tesperature of the presaurized outar wall is $\sim 500^{\circ} \mathrm{C}$ which occurs in the out let tube at the rear of the blanket. Given the inherent differencen between marinum coolngt temperature and anxinim atructure tewperature for the two concepts, for any arbitrary maximu structure teperatura Ifit the pressurtzed aodule concept should perntt coolant outlet teaperatures $40^{\circ} \mathrm{C}$ higher than for the preasurIzed tube concept. Second, for the pressurized tube concept the puaping power required for the blanketa and anifolde together 10 eotinated to be $\sim 3.0 \%$ of reactor thereal power; this compares to $n 1.37$ for the pressurized nodula concept. The difference anounts to 2 $66 \mathrm{MN}$ (work), and would algalficantly reduce net efficleacy for the powar cycle. The raquirement for an actively cooled module wall is a alpificant added complexity and ex poentbly renult in a elpolficant reduction in blenknt breeding capability. This raqui reaent will be furthar invantigated.
Purther evaluation of the two concept. will be performed in the arens of structural analyais, thernelhydraulice, and neutronics to ald in the selection of the design concept to be adopted for the STARFIRE reactor and optinized as an integral part of the reactor deatgn.

\section{Referencee}

1. D. I. Salth, et al., "Asaesment of Solld Breeding Blenket Optiona for Co-ereinl Tokamk Renctors," Bth Sympsiu on Engineering Problene of Fucton Regenrch, San Francisco, Ca., November 1979.

2. C. A. Tracheel, at al., "Meintenance Consfderatione of the STARFIRE Comerciel Tokenk," 8th Sypostur on Engtneering Probless of Fueion Reeeurch, San Franc1sco, Ca.. November 1979.

3. W. M. Staces, Jr., at al., "Tokemak Exper Imentel Power Reactor Concaptual Daef gn", Arsonne Mat1onal Luboratory, AN/CTR-76-3, 1976.

This work we pexforned uadar the suspicen of the Untted states Departent of mersy. 


\section{RITIU HADLINC AND VACLUM CONSIDERATIONS FOR THE STARFIRE COMEERCIAL TORAMAK REACTOR*}

P. A. Finn, R. G. Clemer, V. A. Karon1

Argonne National Laboratory

Argonna, Illinois 60439

and

C. Dillow

HeDonnell Douglas Astronautics Company St. Louis, M1ssour1 63166

\section{flsetract}

Tritius processing and vacuus pumping requirements were analyzed for the STARFIRE conmercial fuston reactor design. It was found that vacuum pumps having a helius capture probability of 0.5 (total hellum pump opeed $1.2 \times 10^{4} \mathrm{~m}^{3} / \mathrm{s}$ ) in combination with the proposed STARFIRE Iinfter-vacuum concept is sufficient to achieve plasma impurity control and, simultaneously, high fractional burnup (11z). The high fractional burnup and Dinimum fuel recycle time result in a very low fuel cycle tritium inventory, $21300 \mathrm{~B}$. A "Lean-T burn" method that can further reduce the fuel cycle inventory by 30-50z is discussed. $b_{2} O$ is proposed is a first wall coolant from considerations of plasma contamination (due to hydrogen isotupe perrueation through coolant tubes) and enrichment of recycled tritium from the coolant circult. Tritium recovery from solid breeders, under realist.lc structural and breeder materials constraints, eppears to represent a formidable task. The tritium Inventory in the solid breeder is estimated to be as h1gh as $10 \mathrm{~kg}$, which would make the blanket the largest single hold-up point for tritium in the plant.

\section{Introduction}

The purpose of this paper is to describe the tritium containment and handling atrategy developed during the early stages of the STARFIRE comercial tokamak renctor conceptual design study 1 . Major objectives of the tritium-related studies for STARFIRE include (1) - Ininum total tritlum Inventory and, more importantly, minimura tritium holdup in those reactor systems and components wherein the tritium is vulnerable to release (e.g., the vacuum system, fuel recycle system, and blanket system), (2) a tritium release rate from the plant of less than $1 \mathrm{C1} / \mathrm{day} / \mathrm{Gwth}$ during normal operatlon $^{2}$, and (3) a functional tritium facflity design that is amenable to rapid maintenance and repair and has aigh rellability factor.

Consiatent with the above objectives, a Ifoitervacuum concept ${ }^{3}$ has been concelved for STARFIRE which appears to permit adequate plasma impurity control and, - Amultaneously, high fractional burnup (1.e., >10\%). Vacuun punping considerations and several unique strategies designed to minimize tritium inventories in the evacuation and fuel recycle systems are discussed. In general, the proposed fuel purification, enrichment, and circulation methods for STARFIRE are along the ines currently under development in the Tritiun Sygtens Test Asmenbly (TSTA) program at LASL and are not dwelled upon herein. Present plans for recovering tritium fron the coolant circuits and from the breeder blanket are aleo suranarized.

\section{Plegen Impurity Control}

Decauce STARFire is dentgned for continuous burn but hal no magnetic divertor, impuritien and, coneonitantly, a cubatantiel anount of unburned fuel aust be

Work uupported by. the U.S. Departwent of Energy.

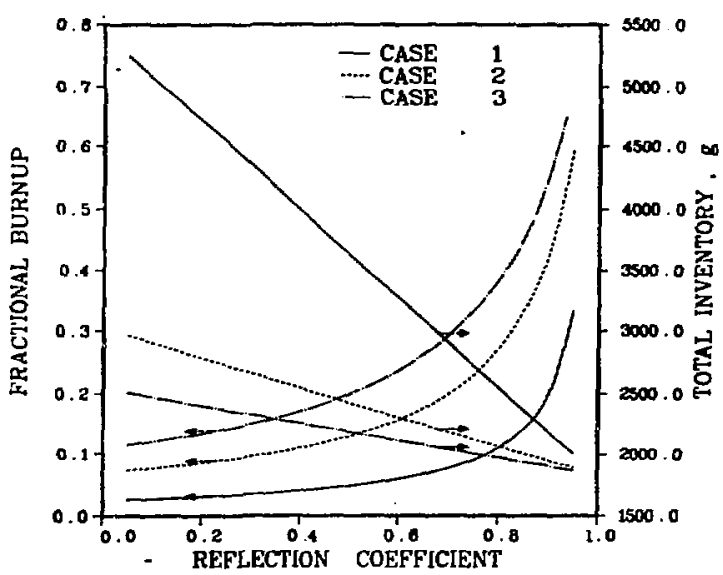

Fig. 1. Effect of Reflection Coefficlent on Fractional Buraup and Tritium Inventory

continuously remioved from the torus by the limitervacuum system ${ }^{3}$. A series of parametric trade studies were performed to assess the impact of Impurity control upon tritium inventory in the fuel cycle. Figure 1 is a typical example, showing the effect of the reflection coefficient (the probability that a particle escaping the plasa will return to the plasma before being trapped by the 11miter or the first wall) upon fractional burnup and tritium inventory. The three cases represent values of $1 \mathrm{c}, 3 \mathrm{~s}$, and 5 for particle confinewent time $\left(\tau_{p}\right)$. (The total inventory includes an assuned $1 \mathrm{~kg}$ of tritium in the blanket.) As the reflection coefficient ( $R$ ) Increases, the fractional burnup increases. As the fractional burnup increases, fuel flow rates decrease and, therefore, tritiun inventories In the fuel cycle decrease as well. A highly effictent impurity control schese, on the other hand, is tantamount to having a very low value of $R$. It is evident that maxialzing plaana purity will result in a low fractional burnup and a large fuel cycle inventory. In order to minielze tritium inventory in the fuel cycle, It is necessary to have the equivalent of relatively Inefficient divertor. Consistent with the objectives of anima tritiun inveatory, the Iiniter-vacum ayste wa welected as the plasw inpurity control wethod for the STARFIRE design.

\section{Vecuu Pupping Systen}

The prinary vacuin boundary of the STARFIRE vacua cyaten 1s at the inner wall of the shield. A pair of liniters pase circuaferentially around the outer 

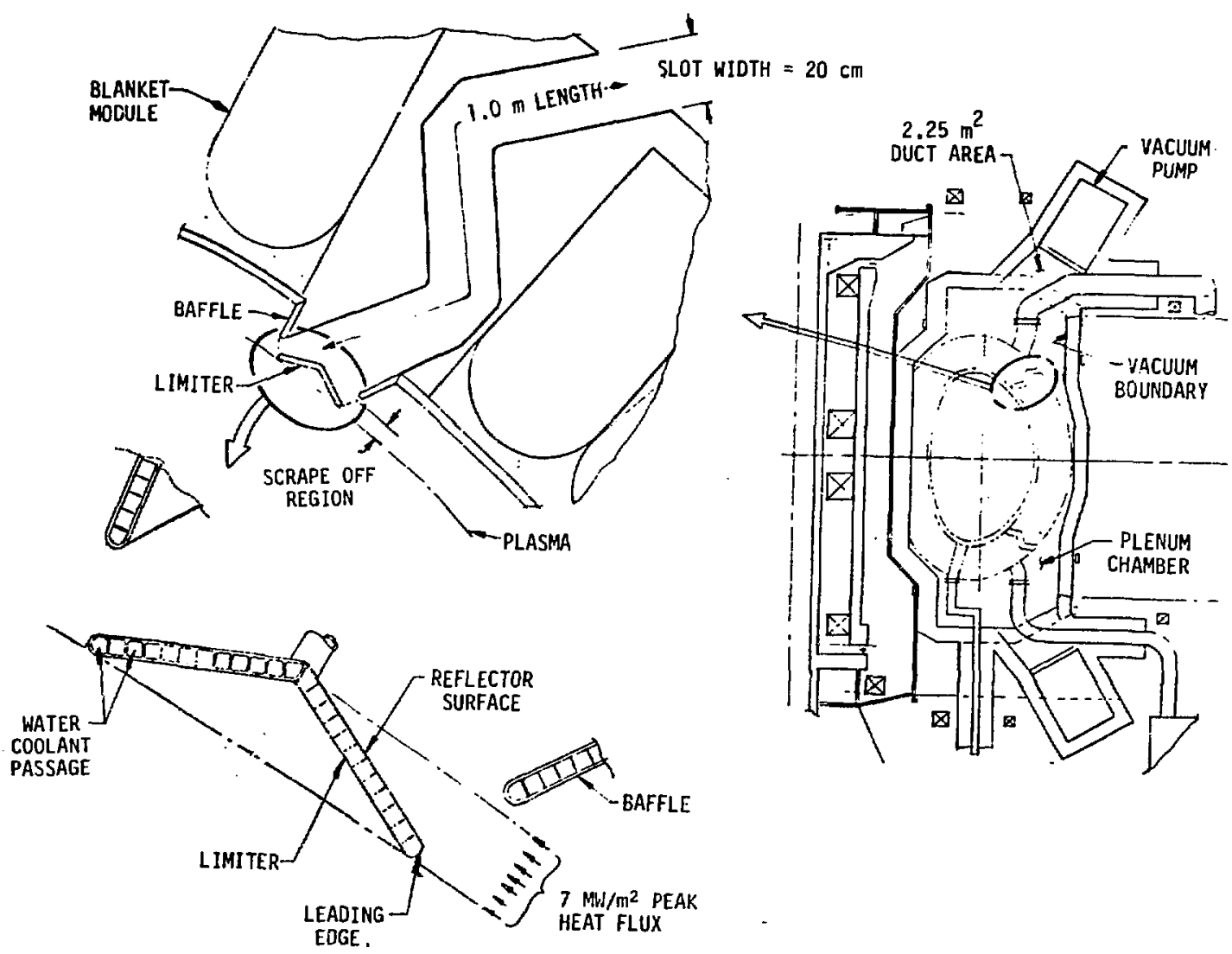

F1g. 2. Design of Limiter-Vacuum Concept

edge of the plasma region, and deflect lons from the scrape-off zone into the adjacent slots in the first wall. The slots are 60 meters long and $20 \mathrm{~cm}$ wide and penetrate the first wall and blanket. The location and configuration of the limiter is optimized to maximize the probability of a molecule entering the slot after striking the limiter. Each slot contains a step to reduce neutron streaming as shown in Fig. 2. In the molecular flow region this step has minimal effects on the conductance, the only consideration being the additional slot length required to provide the step. A large volume plenum exists between the outside of the first wall and the inside of the shield. Twenty-four 1.7 meter diameter, 1.5 meter long vacuum ducts penetrate the shield and provide access for liquid helium cryogenic pumps.

The liquid helfum cryogentc pumps will be of the compound varlety in which hydrogen and 1 ts isotopes are pumped by cryocondensation on a licquid helium cooled panel and helium is cryosorbed on a $4.2 \mathrm{~K}$ molecular sleve surface. The cryosorption surface on such a pump can become saturated with hellum and will require regeneration after approximately elght hours of operation. Regeneration will be accomplished by stopp fig the 1iquid helium flow and allowing the sorption surface to warm, whereupon the helium is released and puraped away by an auxiliary pumping system.

If the impurity control system is to remove inpuritles at a rate sufficient to maintain a steady-state continuous burn plasma, $25 \%$ of the molecules which enter the slots at the first wall must be pumped. An analysis of the vacuum system pumping probab $f$ lity was performed. The slots were treated as rectangular ducts and were assumed to be in series with the cIrcular vacuum ducts at the inner wall of the shield. The number and size of circular vacuum ducts were assumed to be fixed for this analysis. A large volume plenum exists between the exit of the slots and the entrance to the circular ducts. This volume is assumed to have minimal effect on the system pumping probability. The final element in the vacuum pumping analysis is the cryogenic vacuum pump. A capture probability must be assigned to complete the calculations. A factor was also included to account for the directional nature of the molecules entering the slots, which enhances the system pumping probability.

The results of these calculations are presented in F1g. 3. The total system pumping probability is shown as a function of slot width for varlous cryogenic pump capture probabilities. It is seen that an overall pumping probabillty of 0.25 can be achieved for a $20-\mathrm{cm}$ wide slot if a cryogentc punp capture probability of 0.5 is assumed. Such capture probabilfties are beyond the present state of the art, but may become feasible as cryogenic pumping technology is advanced. Enlarging the slot widths beyond $20 \mathrm{~cm}$, for a fixed vacuum duct geometry, w1ll not improve the system pumping probability. However, widened slots will significantly increase the probability of a molecule entering the slots after striking the 11 miter surface and may thus reduce the required pumping probability. The calculated total helium putoping speed for this system is $1.25 \times 10^{3} \mathrm{~m}^{3} / \mathrm{s}$ at the 1initer, and $1.2 \times 10^{4} \mathrm{~m}^{3} / \mathrm{s}$ at the pumps. 
YACILA SYSTEM PLUPING PROBABILITY

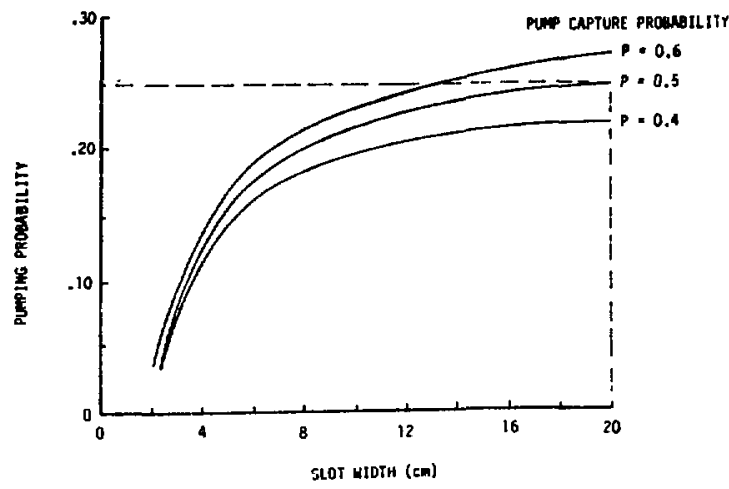

F18. 3. Vacuum Pumping Requirements for LimiterVacuum System

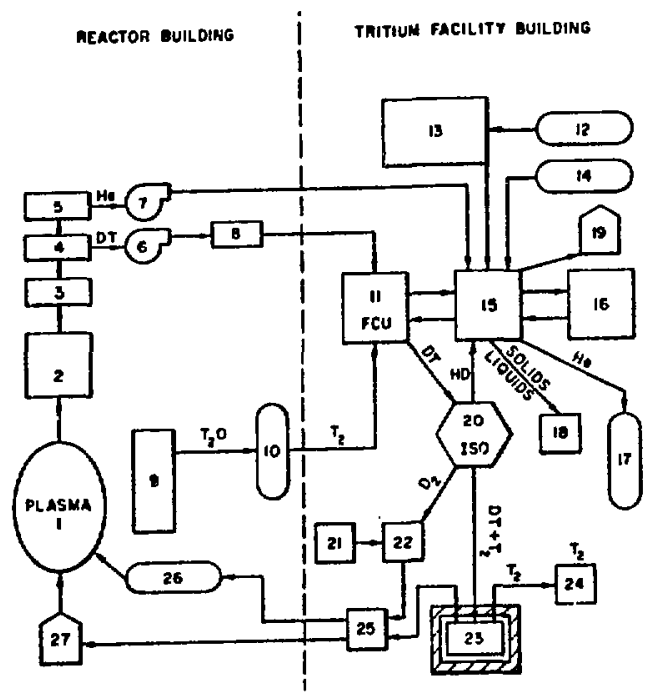

1. Plasma Chamber

2. Limiter Plates

3. Debris Separator

4. D-T Cryocondensation Pump

5. Helium Pump

6,7. Regeneration Pumps

8. Metal Bellows Pumps

9. Breeder Blanket

10. Electrolysis Unit

11. Fuel Cleanup Unit

12. Tertlary Enclosures

13. Emergency Air Detritiation System

14. Secondary Enclosures, Purge Streams

15. Tritiated Waste Treatment

16. Water/Tritium Recovery Unit

17. Hellum (tritfum-free)

18. Tritlated Waste -- Liquids and Sollds

19. Detritlated Gases: $\mathrm{N}_{2}, \mathrm{O}_{2}, \mathrm{CO}_{2}, \mathrm{Ar}$

20. Isotopic Separation Unit

21.. $D_{2}$ Supply

22. D2 Storage

23. DT and $T_{2}$ Storage

24. $T_{2}$ Sh1pment/Recelving

25. Fuel Blender

26. Gas Fueling

27. Pellet Fueler

Figure 4. Fuel Cycle Scenario for STARFIRE

\section{Fue1 Cycle}

The fuel cycle scenarlo shown in FIg. 4 has been developed for STARFIRE. Starting with the plasma chamber, the first 1 tem encountered is the 11miter-vacuut. oystem. The DT is pumped by cryocondensation pumping and the He 13 pumped by cryosorption pumping. Recent results ${ }^{5}$ indicate that an essentially clean separation between He and hydrogen isotopes can be achieved with a cryocondensation/cryosorption pump configuration. The helium is then passed to the Tritlated kaste Treatment (TWT) subsystem for removal of trace amounts of tritium. The DT is regenerated from the condensation pump (two sets are operated in tandem), pressurized to abnut $0.1 \mathrm{MPa}(1 \mathrm{~atm})$, and transferred to the Fuel Cleanup Unit (FCU), where condensibles are rtmoved to levels of $<1$ wppm. ${ }^{4}$ The tritium in the breeder blanket will be recovered as $T_{2} O$. Upon reduction, the bred tritium is passed to the FCU. The purified fuel is then isotopically enrlehed and prepared for refueling. The fuel processing subsystems are contained within gloveboxes, which in turn are located in a separate tritium facility bullding.

The tritium and vacuum system parameters for STARFIRE are listed in Table 1 . The fuel recycle time and reserve scorage have been absulutely mininized. Redundancy and relfability of fuel processing and tritium recovery subsystems are implicitly required.

Table 1. Tritium Facility and Vacuum System Parameters for the STARFIRE

\section{Torus Evacuation System Parameters}

Fractional burnup

Evacuation volume $\left(\mathrm{m}^{3}\right)$

Gas Load-Limiter $\left(\mathrm{Pa}-\mathrm{m}^{3} / \mathrm{s}\right)$

Total Pump Speed at liniter $\left(\mathrm{m}^{3} / \mathrm{s}\right)$

Total Rated Pump Spced-DT $\left(\mathrm{m}^{3} / \mathrm{s}\right)$

Total Rated Pump Speed-Hle $\left(\mathrm{m}^{3} / \mathrm{s}\right)$

Cryopanel Surface-Lin. $\left(\mathrm{m}^{2}\right)$

Tritium and Fuel Processing Parameters

Tritium Burnup per Day (g)

Tritium Exhaust per Day $(g)$

Tritium Fueling per Day (g)

Tritlum Input per Day (g)

Hellum Exhaust per Day (g)

Tritium Bred per Day $(g)$

Tritium Decay per Year $(\xi)$

Doubling Inventory $(\mathrm{g})$

Doubling Time (years)

*Brecding Ratio

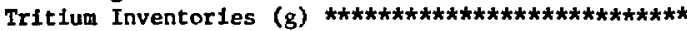

Vacuum Pumps

Storage

Surge Tank

LIquefaction Unit

Cryogenic Distillation Cascade

Fuel Preparation

Tritium Inventory in Fuel Cycle

Emergency A1r Detritiation System (E.D.S.)

Kaximum Concelvable Release (g)

Initial Conc. $\left(\mu \mathrm{C} 1 / \mathrm{m}^{3}\right)$

*Cleanup Time (hours)

* Volume of Reactor Bldg. $\left(\mathrm{m}^{3}\right)$

*Decontamination Factor

*Cleanup Efficiency

E.D.S. Flow Rate $\left(\mathrm{m}^{3} / \mathrm{s}\right)$

E.v.S. Flow Rate ( $\mathrm{z}$ BIdg. vol/min)

*T Level Stacked $\left(\mu \mathrm{Cl} / \mathrm{m}^{3}\right)$

Tritlum Release (C1)

Vent Rate $\left(\mathrm{m}^{3} / \mathrm{s}\right)$

Tritiun Vented to Env. (Ci)
0.11

902.8

$9.89 \mathrm{E}$ ol

2.6E 03

$2.0 \mathrm{E} 04$

$1.2 \mathrm{E} 04$

2.4E 02

495.40

$3.99 \mathrm{E} 03$

$4.48 \mathrm{E} 03$

$4.48 \mathrm{E} .03$

659.

498.

143.

$3.60 \mathrm{E} 03$

5.

1.005

330.

495.

83.

45.

105.

240.

1300 .

818.10

3.93E 07

48.00

$2.00 E 05$

1.00E 06

0.900 .

17.5

0.52

50.000

10.000

$3.33 E 00$

$1.50 \mathrm{E} 00$ 
Table 1. Tritium Facility and Vacuum System Parameters for the STARFIRE (Contd,)

Tritiun and Yacuum Systems Costs (SM)

$\begin{array}{lll}\text { Ptping } & 2.0 \\ \text { Isotopic Separation Unit } & 2.0 & \\ \text { Gloveboxes and Puriflers } & 6.1 & \\ \text { Misc. T Facility Costs } & 2.4 & \\ \text { Pellet Fueling } & 8.7 & \\ \text { Total Fue1 Processing } & & 21.0 \\ \text { Cost - E.D.S. } & 19.5 \\ \text { Cost - Limiter-Vacuum System } & 17.0 \\ \text { Total Tritium + Vacuum Systems } & 57.5\end{array}$

The Concept of a "lean-T" Burn

A method for reducing the tritium inventory by operating the plasma with a $D / T$ ratio $>1$ is being considered. A simflar method was proposed by conn, et $a 1^{6}$, In which the plasma has equal deuterium and trittum in the center but is ricl: in deuterium at the edge. The "Lean- $I$ " method is comp] Imentary to that of Conn. As shown in Table 2 , as the $D / T$ ratlo increases, the tritium exhaust rate decreases. It is assumed that the fusion power is kept constant by maintaining a constant value of $\mathrm{N}_{\mathrm{b}} \times \mathrm{N}_{\mathrm{T}}$. As the $\mathrm{D} / \mathrm{T}$ ratio 1ncreases, the $\operatorname{tr} \mathrm{I}-$ tium densiry decreases while the deuterium density and the total density $\mathrm{N}_{\text {tot }}$ increase. Ascording to Alcator scaling, the particle confinement time increases linearly with increasing densicy. Thus, as the $D / T$ ratio is Increased, the gas load remains constant although $N_{\text {tot }}$ increases. Also, tritium exhaust rates (proportiona] to $\mathrm{N}_{\mathrm{T}} / \mathrm{N}_{\text {tot }}$ ) can be substantially reduced. The tradeof 5 of this scheme is that a higher density is required for a fixed power level and thus higher $B$ or inigher field is required. As shown in Table 2, a $\mathrm{V} / \mathrm{T}$ ratio of 2 can reduce trictum exhaust rates (and inventories) by $233 \%$. In order to do this, $N_{\text {tot }}$ is filcreased $6 \%$ and therefore $B$ would have to be increased $6 \%$ (e.g., from $5 \%$ to $5.3 \%$ ).

\section{Tritium Recovery from the Blanket}

The STARFIRE blanket design is currently focused on the use of solid oxide-based breeders and hellum coolant. Methods of tritiun recovery using a He purge strean are currently being investigated. Realistic breeder and materials constraints, together with diffusion and mass transfer considerations, appear to make 1t very difficult to keep the tritium inventory in $\mathrm{Li}_{2} \mathrm{O}$ below $1 \mathrm{~kg} .{ }^{7}$ For example, the equilibrium $\mathrm{T}_{2} \mathrm{O}$ vapor pressure above LiOT in solution in $\mathrm{L1}_{2} \mathrm{O}$ for a tritium inventory of $1 \mathrm{~kg}$ is calculated to be $210^{-6}$ torr.. Recovery of tritium as $\mathrm{T}_{2} \mathrm{O}$ by a purge stream requires a $\mathrm{T}_{2} \mathrm{O}$ (or HTO) pressure of $\sim 10^{-3}$ torr for reasonable purge flow ratos. The LiOT concentration must be increased nearly three orders of magnitude in order for in-situ extraction to be viable. Both in-situ and out-ofreactor methods of tritium recovery are being investigated. It appears likely that the blanket tritium inventory will have to be about $10 \mathrm{~kg}$ at steady-state recovery to achleve a credible integrated blanket design/operating scenarlo. Key tradeofes to the blanket Inventory problem lie in talloring the breeder compound chemistry to achleve more favcrable tritium release characteristics. This approach could result in the need to incorporate neutron multiplying zones in the blanket modules. In this same vein, anrichment of ${ }^{6}$ L1 in the breeder compound would help to reduce the total mass of brecder material.

Tritium in the Blanket Coolant (Helium)

A calculation of permeation losses from the helfum coolant through the steam generator was performed. The ctean generator which 18 constructed of Croloy
(Fe-214 $\mathrm{Cr}-1 \mathrm{MO}$ ) has a tube heat transfer area of $5440 \mathrm{~m}^{2}$ $\left(58,500 \mathrm{ft}^{2}\right)$, a tube thickness of $2.0 \mathrm{~mm}(0.080 \mathrm{ln})$, and an average cube temperature of about $350^{\circ} \mathrm{C}$. A1though the He coolant does not contact the breeder directly, as a worst case it is conservatively assumed thet a leak develops and the $\mathrm{T}_{2} \mathrm{O}$ pressure is $10^{-2} \mathrm{~Pa}$. Assuming equilibrium with $1 \mathrm{~Pa}^{2} \mathrm{O}_{2}$, the $\mathrm{T}$, pressure is then $10^{-1} 3 \mathrm{~Pa}$. Given the tritium permeability of $0.4 \mathrm{~mm}^{3}(\mathrm{STP})=\mathrm{mm} / \mathrm{s} \cdot \mathrm{m}^{2} \cdot \sqrt{\mathrm{Pa}}(0.10 \mathrm{Cl} / \mathrm{Day} \cdot \mathrm{m} \sqrt{\mathrm{Pa}})$, the tritium permeation loss is $0.10 \mathrm{C1} / \mathrm{day}$. It is noted that no credit was taken for a permeation barrler, which probably could reduce the rate by a factor of about 150.8 It is concluded that, due to the fact that the tritium is predominantly in the oxidized form, and due to the relatively low cemperature $\left(350^{\circ} \mathrm{C}\right)$, tritium permeation losses w1ll be very small and an intermedtate loop is not required.

Table 2. Effect of "Lean-T" Burn (in relative units)

\begin{tabular}{ccccc}
$\mathrm{N}_{\mathrm{D}} / \mathrm{N}_{\mathrm{T}}$ ratio & $\begin{array}{c}\text { Total Ion } \\
\text { Dens1ty }\end{array}$ & Gas Load & $\begin{array}{c}\text { Tritium } \\
\text { Density }\end{array}$ & $\begin{array}{c}\text { Tritiurn } \\
\text { Exhaust } \\
\text { Rates }\end{array}$ \\
\hline $\begin{aligned} 1 \\
2\end{aligned}$ & 1.00 & 1.00 & 1.00 & 1.00 \\
4 & 1.06 & 1.00 & 0.71 & 0.67 \\
10 & 1.25 & 1.00 & 0.50 & 0.40
\end{tabular}

Implications of the Choice of Water (or $\mathrm{D}_{2}$ O) as a First-Wa11 Coolant

The STARFIRE design currently employs water as the first-wall coolant. During the course of reactor operation, significant anvunts of tritium will pass front the plasma chamber into the first-wall coolant water. This tritium is essentially all converted to HTO, in which form permeation rates are very small $\quad<<0.1$ C1/day) and tritium is lost only to the extent that the coolant water itself ts physically lost. Thus, water is a sink for tritlum. Permeation rates for trttium passing from the plisma chamber through the ferritic steel tube wall into the first-wall coolant were calculated (Table 3), First-wa1l temperatures of $300^{\circ}$ and $500^{\circ} \mathrm{C}$ were assumed for the calculation. The driving pressure was assumed to be $0.13 \mathrm{~Pa}\left(10^{-3}\right.$ torr) and the attainable barrier effectiveness was assumed to be 400-K. Comparison of these results with other materials of construction show that permeation rates for stainlass steels w111 be an order of magnitude lower, while more permeable materials, e.g., $T i, V$, and $\mathrm{Nb}$ alloys, will be about two orders of magnitude higher. Steady-state levels (Table 3 ) are achieved when $B$ decay equals about 20 times the annual inleakage rate, assuming that losses are insignificant and that tritium is not actively removed from the water.

For conditions anticipated in systems with a watercooled firgt wall, tritium levels are estimated to be 2 to $100 \mathrm{Cl} / \mathrm{l}$. As a point of reference, $20 \mathrm{cl} / \mathrm{l}$ is typical of the level in the moderator of a heavy water reactor (HWR) after many years of operation, however, some control is implemented to maintain this level. Th1s level gives $\mathrm{H} / \mathrm{T}$ ratios on the order of $10^{5}$ in the water and requires an enrichment of at least six orders of magnitude before one can consider returning the tritium. to the fuel cycle.

The use of. $\mathrm{D}_{2} \mathrm{O}$ as a coolant offers a significant advantage over $\mathrm{H}_{2} \delta$ because deuterlum is a fuel, and therefore, 1sotopic enrichment requirements are somewhat relaxed. For example, the tritium could be recovered in a 997 deuterium mixture, requiring enrichment factors of $\sim 10^{3}$, which 18 two to three orders of magnitude 
Table 3. Sumary of Tritiug Loas Calculations for the Tube Bank First Wall Concept

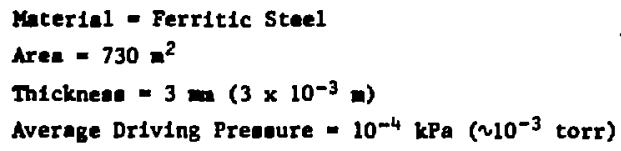

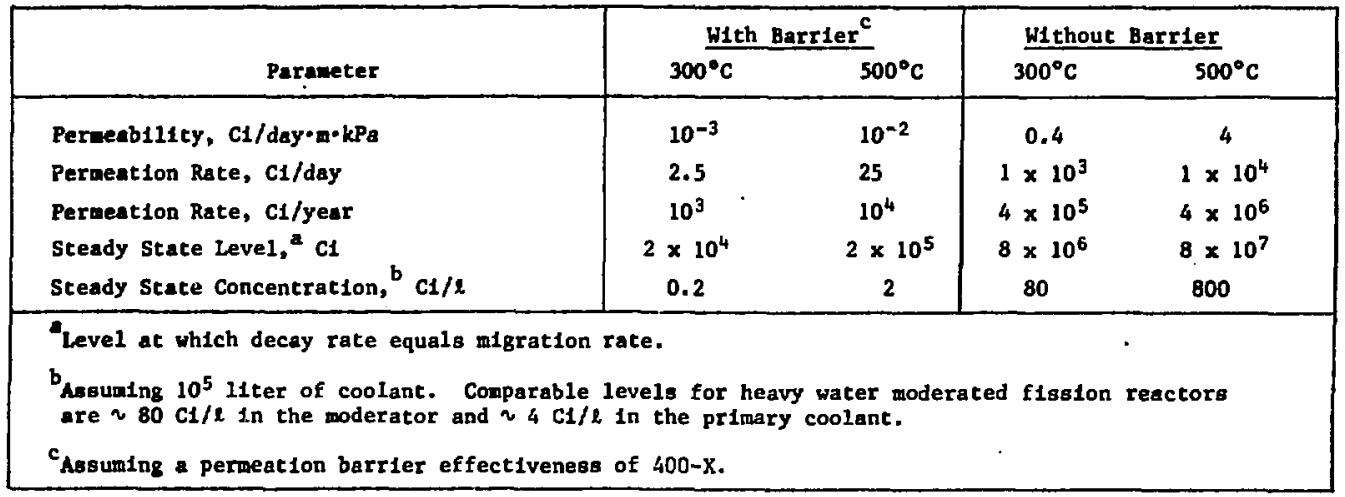

lower than required for 11ght water. Separation factors w11 be somewhat lower for $D_{2} O$, but this is a comparatively small effect. Also, for STARFIRE, $2000 \mathrm{CI} / \mathrm{yr}$ will be generated in the $\mathrm{D}_{2} \mathrm{O}$ coolant from neutron act $1-$ vation of the deuterium. In1s amount is less than that for Inleakage from the plasma. More Importantly, although hydrogen permeation from the coolant through the first wall could affect the plasma performance, deuterium permeation should present no problem. All factors considered, it appears that $D_{2} 0$ is much preferred over $\mathrm{H}_{2} \mathrm{O}$ as a coolant if water is to be used.

\section{Conclustons}

Although the STARFIRE study is still in the early stages of its evolution, it has been possible to draw several important insights and conclusions from the vork on tritfum-relaced aspects done to date. These are enumerated below:

1. Implementation of the limiter-vacuum concept appears to result in adequate plasma Impurity control and, at the same time, a reasonably high fractionel burnup (11x) which leads to reduced tritium throughput requireaents .

2. Vacuum punps having a the capture probability of 0.5 (total le puap speed of $1.2 \times 10^{4} \mathrm{~m}^{3} / \mathrm{s}$ ), although beyond present state of the art, are required to achleve an acceptable vacuum topology.

3. The high fractional burnup coupled with efforts to animize critiun holdup times, leads to low fuel cycle tritiue inventory, थ $1300 \mathrm{~g}$.

4. Use of a "Lean-T" burn could (In princ1ple) reduce the present fuel cycle inventory by from 30 to $50 \%$.

5. It appears that the blanket (solid ceranlc breeder) w11 have the largest tritiun Inventory, perhaps $10 \mathrm{~kg}$ becaune of thernodyanic and ans trancfer constraints.

6. Tritiun Inventories in the blanket coolant (He) and firat wall coolant $\left(D_{2} 0\right)$ are very smell, only a fer ereme, and are considered to be recoverable.
7. $\mathrm{D}_{2} \mathrm{O}$ 1. preferred to $\mathrm{H}_{2} \mathrm{O}$ as a first-wall coolant becausé of considerations óf plasma contamination (from hydrogen 1sotope permeation) and tritium recycle/ enrichment.

\section{References}

1. c. C. Biiker, et al, "STARFIRE - Commerclal Tokanak Power Flant Overvlew," Proc. 8th Symp. on Eng1neering Froblems of Fusion Research, Nov. 13-16, 1979, San Francisco, CA.

2. V. A. Maron1, "Control of Permeation Through Fusion Reactor Structural Materials," Proc. of DOE Environmental Control Symposium, Nov. 28-30, 1978, Washington, DC.

3. J. N. Brooks, et al, "The Impurfty Control System for the 'STARIRE' Comperclal Fusion Reactor," Proc. 8th Symp, on Englneering Problems of Fusion Reaearch, Nov. 13-16, 1979, San Franc1sco, CA.

4. J. L. Anderson and R. H. Sherman, "Tritium Systema Test Aseenbly Design for Major Device Fabrication Review," Log Alamos Scientific Laboratory report LA-6855-P, (June 1977).

5. J. L. Anderson, D. O. Coff In, and C. R. Walthers, Los Alamos Sclentific Laboratory, personal communication (1979).

6. B. Badger, et a1, "Nuwrak," Univeralty of Wisconsin report UWFDM-330, March 1979.

7. D. L. Snfth, R. G. Clermer, and J. W. Dev1a, "Asmensment of Solld Breeder Options for Comerclal Tokamak Reactors," Proc. Bth Syaposiun on EngineerIng Problens of Fuaton Research, Nov, 13-16, 1979, San Iranclsco, $\mathrm{CA}$.

B. T. A. Renner and D. J. Raue, "Trittum Permeation through Fe-2laCr-1Mo Stean Generator Materind," Nucl. Tech. 42, 312 (1979). 


\author{
SUPERCONDUCTLNG POLOTDAL COILS FOR \\ "STARFIRE" COMERCIAL REACTOR" \\ S,-T. Wang, K. Evens, Jr., L. R. Turner, Y.-C. Huang \\ Argonne Nactonal Laboratory \\ Argonne, Illinols 60439 \\ and
}

R. Prater and J. Alcorn

General Atonic Company

San Diego, Callfornia 92138

\section{Sumraxy}

STARFIRE is considered to be the centh commercial tokarak power plant. A preliminary design study on 1 ts superconducting poloidal coll system is presented. Key features of the design studies are: the elimination of the ohwic heating coll; the trade-off studies of the equilibrium fleld coll locations; and the development of a conceptual deslgn for the superconducting equilibrium field colls. Described are the $100 \mathrm{kA}$ cryostable conductor design, the coll structure and evaluation of the coll forces.

\section{Introduction}

STARFIRE ${ }^{1}$ is an assumed steady state operating cosmerclal tokawak based on a continual plasma current mode. The plasma startup, heating and current drive are ccomplished by a lower hybrid if system. This systex eliminates the need for ohmic heating coll systems.

STARFIRE Equ1librium Field (EF) colls provide several important functions. Firstly, the EF colls vill provide the static equilibrium of the plasma against both the radial and the vertical displacements; second $1 y$, the EF colls will elongate the plasma; thirdiy, the EF colls will control the plasma postition; fourthly, the EF colls w1ll provide disruptive instability control; and $f$ inally, the EF colls will drive the plasna through the current induction. If the EF colls were placed Inside the Toroldal Fleld (TF) colls, there would be tremendous difficulties in coll assembly, disassenbly, support, repalr and maintenance; as well as in the assembly, disassembly and malncenance of the blanket and shleld and the first wall. However, If EF colls werc placed outside the TF colls, it is difficult to control plasms position, to generate a sufficiently D-shaped plasma and to control the plasma distuptive instability. Furtherwore, EF colls outside the tF colls w11 require an order of magnitude targer ampere-turns, stored energy and w11l produce large tipping forces and superimposing flelds onto the TF colls. Thus, the location of the EF colla is a key design consideration in the STARFIRE design.

The basic design approach 18 to locate almost all the EF colls outside of the TF co11s; all such EF colls sill be superconducting. A Ilanted number sf segrented copper colls would be located inside the IF colls but outside of the blanket and shield. These auxiliary colls will be used for control purposes. Although this configuration increases the anpere-turns and the rtored enersy of the wagnet systen, the rellabllity and the mantainabllity of the $\mathrm{EF}$ coll system should be tar superior to an Inalde EF coll systed. WIth this confsguration, however, 1t is Important to alnialze the TF col). size. For example, equilibrium calculatlons with

\footnotetext{
Work supported by che U.S. Departwent of Energy
}

EF colis exterior to a toroldal field coll with the outer leg at' 16.8 m showed that a total of about $200 \mathrm{M}$ curns would be required in the EF colls to support plasma with $10 \mathrm{MA}$ current, major radius of $7 \mathrm{~m}$, elongation of 1.6, and beta pololdal $B_{p}$ of 1 . Th1s large EF coll current implies very large local forces on the TF coil and very large stored energy, as vell as great positional sensitivity of the plasma to the EF coll currents. When the coil outer leg is moved in to the current design value of $\approx 13.5 \mathrm{~m}$, the EF coll current Is reduced to around 100 kla-turns, Indicating the Importance of minimizing the TF coll size.

In STARFIRE, the plasma current normal startup and uhutdown pertod will be of the order of 10 to $60 \mathrm{~s}$ and the plasma disruptive shutdown will be of the order of 5 s. Rapid or sudden changes in the plasma position. due, for example, to modifications of the current profile by MHD activity, cannot be followed by the external. EF coll system without oversizing of the power suppiles and difficult constraints on coll manufacture due to the high voltage to be applied to the terminals. It 18 wore practical to caploy the Internal EF colls for the purpose of plasma control. These colls yould be actively controlled and would.carry lifte average current and w11l thus consume little $I^{2} R$ losses.

The blanket and shield are segmented toroldally and Insulated to facilitate the soak- In of the current fields. In the event of a plasua disruption, large voltages w111 be generated in the vicinity of the plasma. These voltages will brcak down the intersegment Insulation of the blanket or the control coll Insulation unless an alternative path for the current is provided. For STARFIRE a system of toroldal conductors w1 th spark gaps will be designed for this purpose.

\section{Superconducting EF Colls}

The locations of the external superconductins equilibrium field colls and the currents in them are deterained as follows. First, an MHD equilibriun of the plasma is determined based on the plasma physics requirements of the reactor. Anong the equilibriua properties are the plasma current distribution and the pololdal mignetic field in the plasma. Part of the poloidal field is produced by the plasma currents. The remeining part, the external field, must be supplied by the EF colls.

For given locations of the EF colls, the required current in them is determined by making a least squares fit of the ficld produced by the colls to the desired external fleld of the MHD equilibriuin. Experience has determined that an average erior of $=0.32$ in matching the desired external fleld is sufficient to reproduce the plasms physics parameters and the desired plasma boundary. Any additional flexiblifty in the coll oystem is used to minimize the stored energy in the EF coll syscew. This procedure is described in dutail long with many exasuples in Reference 3. 
The optinied design is found by systenatically varying the locations of the colls, subject to englneering constraints such as the location of vacuur duets. For STARFIRE $1 x$ was found the configuracion shoun In Fig. I was a satisfactory design. Basically, the plasea $D$ shape is forsed by pulling the plasma outward with the two upper coll pairs (with current in che sume direction as the plasma current) and by puahtng in with the other two. The vacuus ducts come out between the two outermost colls, and the apace between the two upper colly is left for englneering access. The tored energy of $10.1 \mathrm{GJ}$ could be reduced slightly with wore colls. The 98 MAT would, however, Inerease soweuhat wore rapidly. The location of the colls is such that moving any of them a short distance (but not inside the non-allowed space) would increase the stored energy.

The vertical fleld pattern generated by the EF colls is plotted In Fig. 2. The EF colls produce a vercical fleld of about $0.61 \mathrm{~T}$ ac plasma center. The field lines concave to the right are required to generate a nonclrcular plasma. Hovever, the $t$ leld lines will not provide stability against vertical displacement. The total flux contour contributed by boch the superconducting EF colls and the $10.8 \mathrm{MA}$ plasma curreac is shown in F18. 3. The plasma obtained has an elongation of 1.60 and triangularity of 0.5 .

Main characteristics of the EF colls are given In Table 1. The EF colls will have a maximum operatlonal current of $200 \mathrm{kA}$. To reduce spongeness of the h1gh current cable, it is proposed to connect in parallel nll colls above the machine midplane with thelr counterparts below the midplane, thus the.operating current of the superconducting cable in each cotl w121 be $100 \mathrm{kA}$. The EF co1ls w11l have 490 turns in each parallel path. The normal cliarging or discharging voltage for the EF co1ls is about $9.6 \mathrm{kV}$ to $1.6 \mathrm{kV}$ depending upon the 10 second or one minute rampling time and the turn-to-turn voltage is about 18 to $3 \mathrm{~V}$. The self-stored energy of the EF colls is $10.1 \mathrm{GJ}$.

The EF colls will be cooled by pool bolling at $4.2 \mathrm{~K}$ and 1 acmospheric pressure. Pool botling is alaple, Inexpensive, reliable and easy to operate and control.

The euperimposing field on the IF colls generated by both the EF cotls and the plasma to also shown in Fiz. 1. It is seen that the superimposing fleld will generate falrly large tipping forces on the TF colls as vell as Impose an order of $1 \mathrm{~T}$ additional tield margin onto the TF coll winding.

\section{Ax1al Presgure and Hoop Stress}

Table 2 whow the peak fleld and the computed vertical forces per unit length of each EF coll. It is seen that all colla except coll No. 2 will have attractive forces toward the asdplane. The axinl magnetic pressure, $P_{2}, 1$ a function of both axial and radial positlons within a coil erose section. The aaximurs axial agnetic.pressure for each coll is also given in Table 2.

Astuning aniform coil structure, the average hoop stress is the product of the average current density, the man coll radius and the axiel flelt component averazed over the coll cross section. On the other hand, the average radial angetic pressure 10 the product of the average current deneity, the coil radial thickness and the average axial field cosponent. Both the hoop stress and che radial engetic preswure for each coll ere conputed and

1isted in Table 2. Since the coll sean radiun is senerally larger than the coll radial thicknesn, the average loop atress la generally larger than the average radial magnectc pressure. The maximum magnetic pressure is $823 \mathrm{~kg} / \mathrm{Cn}^{2}$ (about 12,000 psi) exarting on Coli Mo. 4 .

\section{Conductor Design and Coll structure}

As an 1llustration, a $100 \mathrm{kA}$ cable desiga is shown In Fig. 4. The cable is designed with full cryostablifty and reasonably low ac losses for the 10 s to 60 s normal charging and discharging purposes. To achleve high rellability, the EF colls must by cryoctatically stable. To withstand the $d B / d t$ of about $0.8 \mathrm{~T} / \mathrm{s}$ during the current swing, Individual superconducting strands in the basic cable and the basic cables In the full conductor must be fully transposed. The full conductor was achieved by fully transposing 24 basic cables around a G-10 strip so that the cable will have a height of $2.4 \mathrm{ca}$ by a whth of $13.8 \mathrm{ca}$. Spiral urapping vet ted-wound fiberglass of $3 \mathrm{~m}$ in thickness 1s eaployed to band these baslc cables rogether. The fiberglass band will also provide a liquid helium channel of $1 \mathrm{~cm}$ in width by $0.3 \mathrm{~cm}$ in depth by $13.8 \mathrm{~cm}$ in lengeh.

Because of the spongeness of the $100 \mathrm{kA}$ cable, it 1s Important that the EF coll structure must be designed to 1solate the electromagnet1c forces in both the axial and the radial direction. Figure 5 illus trates such a coll structure using the $100 \mathrm{kh}$ cable. The cable will be loosely fitced into a scainless sceel channel with hellum coollng and venting slots. The ntninless steel channel will support both the axial and the radial electromagnetic forces. Since the cable will be loosely fitted into the channel, the coll body forces could not be accumulated to the cable. The axial coll forces will be bridged through the G-10 plates, which 1s the support plate for each pancake coll layer. These supporting plates will be machined co have radially outward cooling channels for helium gas venting.

Table I

Characteristice of Superconducting EF Coll

Superconductor/Stabllizer Stability Operating Current

Cooling

Operaring Temperature

Average Current Density

Magnetic Field at Plasma Center

Total Ampere Turn:

Maxdmum $\mathrm{dB} / \mathrm{dt}$ (normal operation)

Self -Stored Energy

Powex Supply Yoltage

Volt-Second to Planma*

self Inductance

Mutual Inductance to Plasea

"Plasma self Inductance is $12 \times 10^{-6} \mathrm{H}$ and Its stored enersy is about $700 \mathrm{~mJ}$

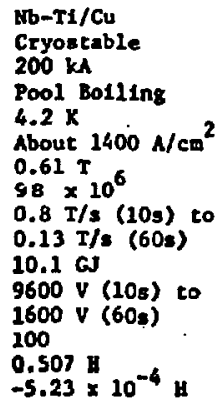


Table 2

Vartical Fotces, Axial Pressure and Hoop Strese

Average Current

Denaity $\left(\mathrm{A} / \mathrm{ca}^{2}\right)$

Peak Field

(T)

Vertical Force* $\left(10^{3} \mathrm{~kg} / \mathrm{cm}\right)$

Hax. Axial Pressure, $P_{2}\left(\mathrm{~kg} / \mathrm{cm}^{2}\right)$

B2

(T)

Average Hoop Stress, б. $\left(\mathrm{kg} / \mathrm{cm}^{2}\right)$

radial Magnetic

Preseure, $\bar{\sigma}_{r}\left(\mathrm{~kg} / \mathrm{cm}^{2}\right)$
Co11 Numbar
1

1382

vithout plasma vith plasma

vithout plasa with plesma

without plasma with plasax

without plasma with plasma

without plassa with plasua

without plasma

with plasma

7.76

6.82

$$
2
$$

$\$ 382$

1186

1209

*Forces pointing toward the STARFIRE midplane are positive.

Torces pointing away from the midplane are negative.

\section{References}

1. C. C. Baker, S. D. Harkness, D. A. DeFreece, C. A. Irachse1, D. Grauman. J. Kokoszensk1, "STARFIREComerclal Tokanak Power Plant Oyerview," Th1s Proceeding.

2. R. Prater, N. Ohyubu, x. Evans, "Pololdal Magnetic Fleld Coll Considerations for a Comnercial Tokamak Reactor," This Proceeding.

3. R. Evans, Ji, D. A. Ehst, P. Messerschuidt, "Equ1libriun Field Call Considerations for Tokamak Resctors." Proceedings of the Third Topical Meering on the Technology of Controlled Nuclear Fusion, Averican thuclear Soclety Publication CONF-780508, Vol. 2, p. 2084 (1978).

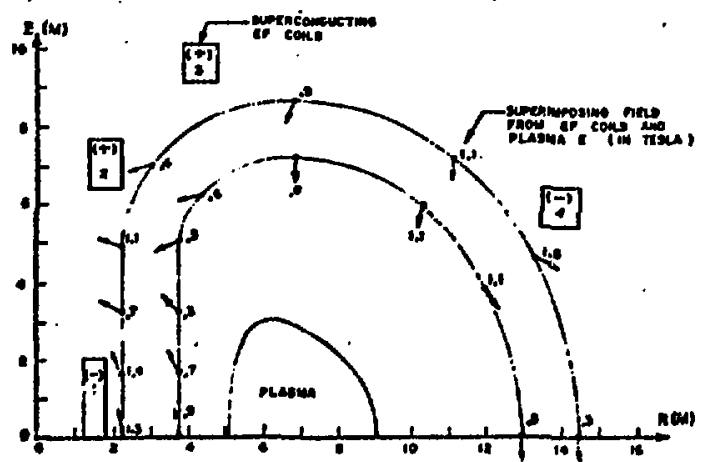

F18. 2. EF colls Contiguration

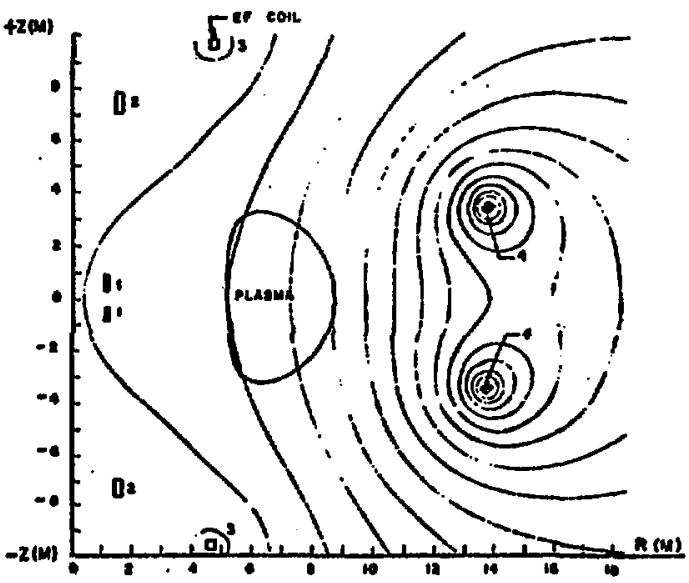

718. 2. Equilibrium Field Patcem for xoncircular Plixear 


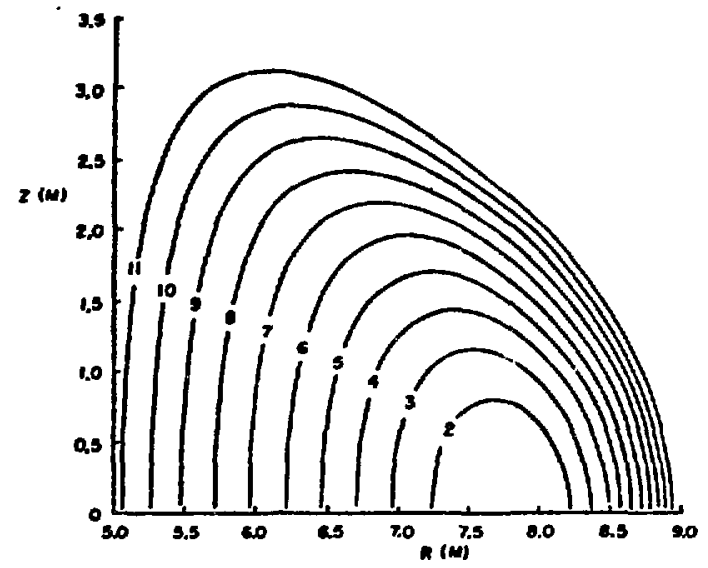

Fiz. 3. Total Flux Contour of STARtiRE

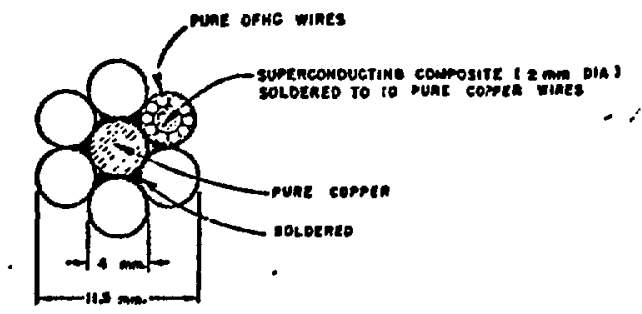

450OA BASIC CABLE

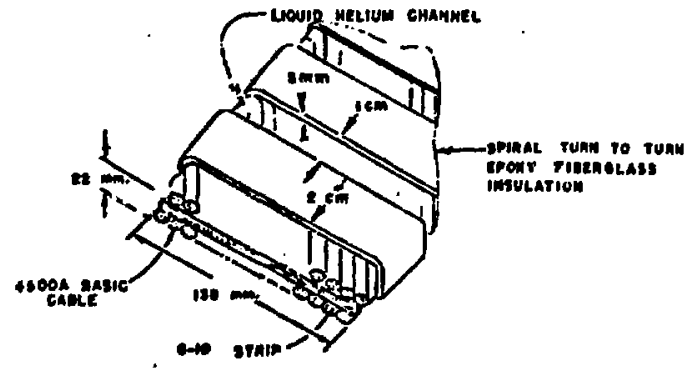

F1z. 4. 100 kA Cryoutable Cable Conductor
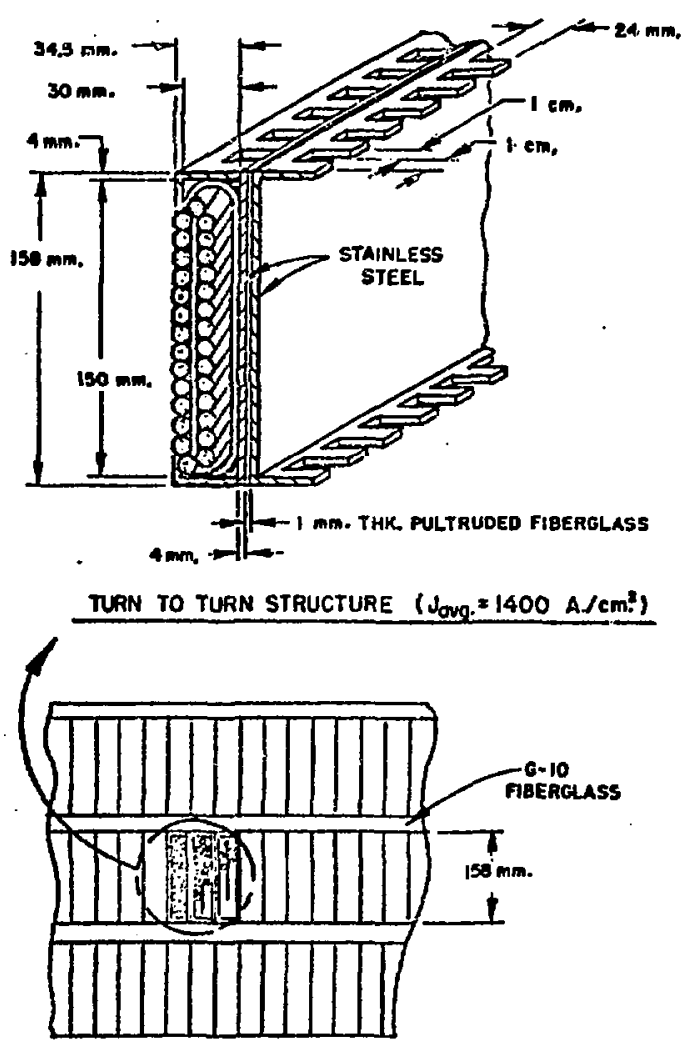

TYPICAL GROSS-SECTION OF COIL STRUCTURE

F18. 5. EF coll structure 


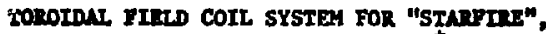
A PRELIMINARY ASSESSIENT

\author{
John S. Alcorn \\ General Atonic Colpany \\ San D1ego, Callfornta 92138 \\ and \\ S. T. Wang and L. R. Tumer \\ Argonne thational Laboratory
}

Argonne, ILl1nots 60440

An Important element of STARFIRE is the 12-coll. superconducting coroidal field coll system which is saquired to generate 5.6 tesla at the $7.0 \mathrm{~m}$ plasma axis, with a peak-to-peak field ripple of 17 (maximum). Internal spacial requirerents diccace a clear bore bout $15-1 / 2$ al high $\times 10$ w wide, resulting in a total stored energy of $67 \mathrm{cJ}$.

\section{Key Design Issues}

One should bear in wind that this would be a truly imenense manet systen, the size, mass, btored energy, refrigeration requirements and cost of which place it far beyond any existing superconducting device. Yet, every aspect of such a system 1s, or should be, a logical, stralghtforward extension of present technology.

Among the key Issues to be addressed in the denign are the following, not necessarily listed in their order of importance:

- Selection of superconductor matertal and configuration.

- Cryogenic and structural accomodation of the heat loads resulting from plaswa neutron radiation and disruptions.

- Support of the colls against the out-of-plane (overturning) loads generated by the exteral pololdal fleld coll system.

- Ease, and location of manufactura.

- Operational reliability.

- Maincainabilicy.

- Kinimization of shutdown, and end-of-11fe radioactivity.

The first three of these 1tems are diacussed under selection of Basic Design Features (below).

An important consideration is the feasibility of transporting completed TF-colls from a central manufacturing plant to a distant reactor site, rather than wind them "on location". This will be Investigated by GA and Parmons personnel in the near future.

of supreme importance for the STARFIRE TF-colls is eseurance of operational rellablifty. This lo achleved through a combination of sound, stralghtforward desiga; good manulacturing practice; and comprahenelve compouont and syatem testing.

At beat, the removal and replacement of a TF-coll following an In-eervice fallure would ba a costly, time consuning operation. The princlpal difficultien here would be removal of enchine comoneats surrounding the cotl, and timely muafacture of a replacenent. Nevertheless, the colls should be desigaed for rolative ease of renovel fron the toroldal array. (Demoutable. superconducting joirts ere not regarded as a feastble option. Their very complextty and bulk would likely mean that any fallure would occur in the joints themselves.)

\section{Selection of Basic Design Features}

The goal of this study is not to produce a detalled "nuts-and-bolts" design for each ajor system, but rather, to identify and present viable solutions to the various fundamental design aspects. Basic design features of the TF-coll system Include the conductor materials, configuration, and support; coil cooling method; coll design; cryostat macerials, design ind support.

\section{Corduceor Materfal}

Verlous design studies at GA and elsewhere lndicate that 10 tesla is about the upper practical Ifmit for employment of NbT1 cooled with liquid hellum at $4.2 \mathrm{X}$ and one atmosphere. Therefore, in the high field region $(9-11 \mathrm{~T})$ of an 11 tesla STARFIRE TF-coil, selection of MbjSn appears to be warranted, based upon anticlpated fabritation and metallurgical advances during the next two or three decades. Nevertheleas, $\mathrm{Mb} 3 \mathrm{Sn}$ is an inherently brittle material, which can tolerate very little tensile strain.

Although high purity aluminum offers potentinl advantages of high conductivity, these presencly appear to be offset by the difflculty of colrawing 1t with fllanentary $\mathrm{Nb}$ and NoTf. Further, Its much reduced end-of-11fe radioactivity compared to copper is mic1gated by the intimate presence of highly activated superconductor materfals. Copper has therefore been tentatively selected as the stablifzer micerial.

\section{Conductor Configuration}

A $24 \mathrm{kA}$, three level cabled conductor has been chosen for the following reasons:

- To ainimize coil heat loads resulting from plean diaruptions and from time varying polordal flelds.

- To provide a high cooled surface-to-area ratio, an 1oportant cryostability conelderation.

- An a practical, proven design for the fabrication of high current filamentary composite conductor.

- To alnimiza tensile strein experieaced by the $\mathrm{Nb}_{3} \mathrm{Sn}$ auperconductor.

The conductor of each pancake (Iayer) 1s divided into four. grades, the amount and type of superconductor in ench being besed upon the peak field expertenced (5, 7,9 and 11 teria).

Fioric supported by U.3. Departant of Jaors. 
Wb3n to exployed only in the high field (9-13 tecla) region. A bronze diffueton seonetry is employed. with a tantalum barrier to shield the surrounding etebilizer material (as shown in Fig. 1). The $1 \mathrm{~b}$ is reneted with the $\mathrm{Sn}$ of the bronge mutrix after the eabling process is complete but pritor te sfiddap.

The same nuber of componte strands, aubcables and cables are recalned throughout the layer, the ctrand size varying fron grade to grade. The $7-9$ teala and O-S tes $2 \mathrm{M}$ MTI conductor configurations are thown in F1ga. 2 and 3 respectively.

For the Interin Design, cryostability of the conductor has been based simply on the "quasi-static" criterion that, in a resistive region, the "equivalent" beac transfer rate to the co.olent $180.35 \mathrm{w} / \mathrm{cm}^{2}$. Th1s criterion is applied to the 250 amp subcable, where $50 \%$ of 1ts enclosing cylindrica: envelope is ansumed to be affective for beat transfer.

Conductor Hoop and Bearing Load Support

Inhereat in a cabled conductor design, particularly when employing $\mathrm{Nb}_{3} \mathrm{Sn}$, is its IInited ability to support hoop and transversc bearing loads (the latter occurring in the centerpost ragion of a TF-coil). In the selected design, the conductor is sandwiched between two pretenisloned stainless steel scrlps for hoop load support, and flanked by ewo bearling load supports. Thts configuration for the bigh and low field regions is depicted in Figs. 4 and 5 . Note that the bearing support strips are auch wider in the low field, high bearing lcad region.

Stainlese etcel 1: cmployed for these support elemats due to its inigh elastic aodulus (30 Hpsi), compared to aluminum (il Mpsi). This is especially ingortant with $\mathrm{Xb}_{j} \mathrm{Sn}$ conductor in order to lifit hoop strain. (Both tupport strip and conductor would then be discarded and burted after reactor disasembly.)

STARFIRE : TF - COILS

24 KA CONOUCTOR HIGH FIELO REGION (9-II TESLA)

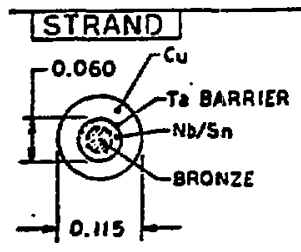

SUBCABLE

CURRENT : $\$ 1.67$ AMP

AFEA OF REACTED Nb3 Sn-BRONZE AEGION : $2.78 \times 10^{-3} \mathrm{~cm}^{2}$

AVG. CUARENT DENSTTY OF Nby SnBRONZE REGION $: 15 \times 10^{3} \mathrm{~N} / \mathrm{cm}^{2}$

CU LAFA: $7.60 \times 10^{-3} \mathrm{~s}^{2}$

REACTION HEAT TREAT: 100 hrs AT $650^{\circ} \mathrm{C}$ (AFTER FINAL CONDUCTOR CABLING)

MO EXTERNAL COATING

CURAENT : 250 AMP

CONFIGURATION : $\$ 1 X$ COMPOSITE STRANOS AROUNO ONE CU WIRE INSULATION : NONE

DIE COMPACTEO TO $90 \%$ OF INITIAL DIAMETER

HEAT FLUXX TO COOLANT IN MORMAL AEGNN $: 0.35 \mathrm{w} / \mathrm{cm}^{2}$

[CABLE]
CONFENT: 1500 AMP
AROUNAON : SIX SUBCABLES
INSULATION : MONE WIRE

STARFIRE: TF-COILS 24 KA CONDUCTOR 7-9 TESLA FIELD REGION

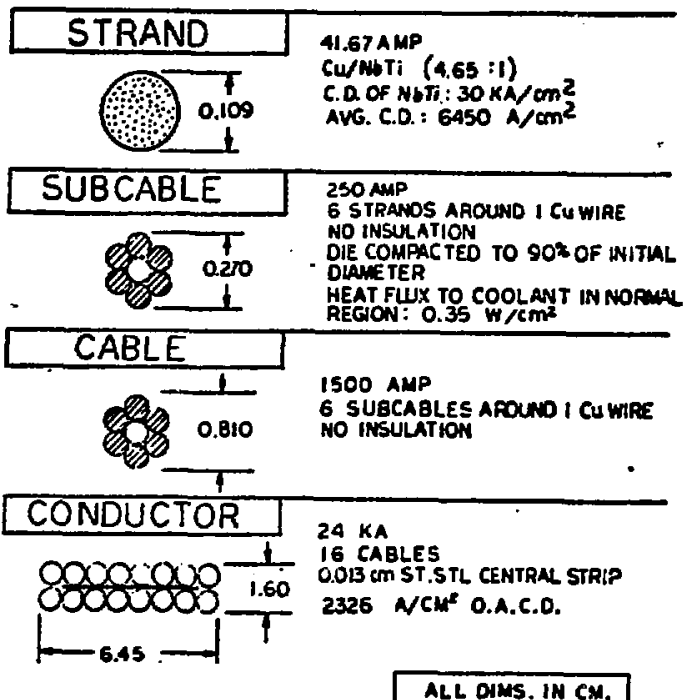

F18. 2

STARFIRE: TF-COILS $24 \mathrm{KA}$ CONDUCTOR LOW FIELD REGION (0-5 TESLA)

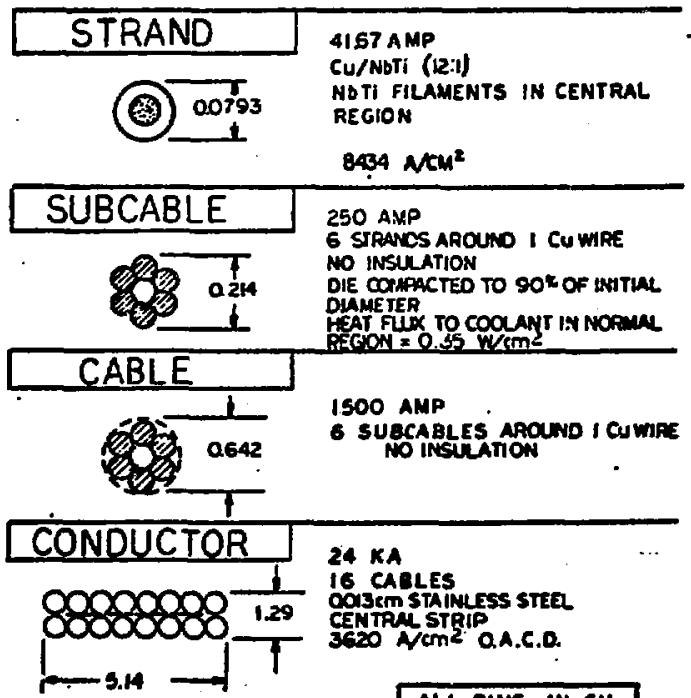

ALL OIMS. IN CM. 


\section{STARFIRE: TF-COILS CONDUCTOR/SUPPORT STRIP MODULES HIGH FIELD REGION $(9-11$ TESLA)}
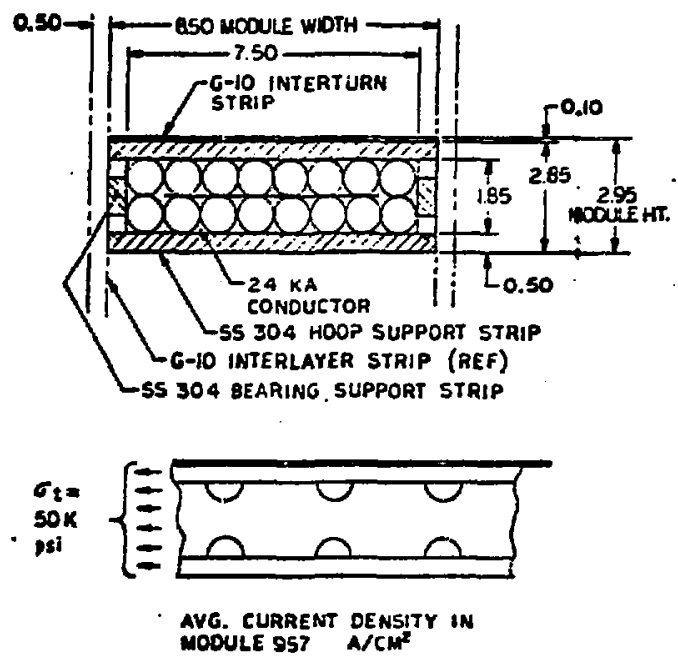

ALL OIMS. IN CH.

115. 4

\section{STARFIRE: TF-COILS CONDUCTOR /SUPPORT STRIP MODULES LOW FIELD REGION (O-5 TESLA)}
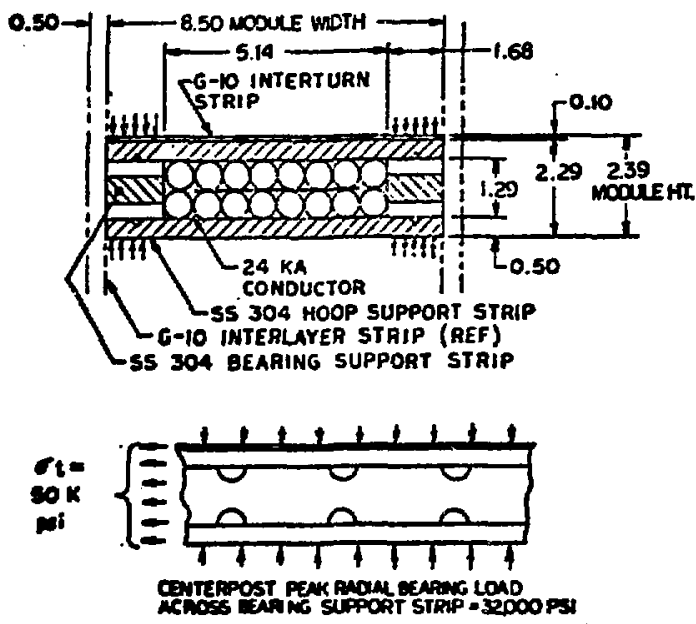

AVG. CURAEMT OENSITY IN CONDUCTORsuppont staIP MOOULE $=1181 . \mathrm{A} / \mathrm{CM}^{2}$

- All ojas. In Em.

\section{Coll cooling rathod}

Fath cooling hes been welected in 12au of forced 110w, based upon consideratione of desten steplicity and operational rellability.

Forced flow cooling introduces copplextetes of conductor design, pumping, and parallel path anifoiding which wore than offiet any potential benefics of Improved heat transfer. In princlple, forced flow cooling through aimple well defined chanela is well underatood and is characterlzed by relatively high heat eransfer rates (example: "hollow" monolithic conductor). However, the flow path gecmetries of cables or braided conductor presently under consideration for large TF-colls are torturous. Proper understanding of such geometrics will require considerable analytical and experimental effort. Certalnly a far greater body of practical operational experience exdets for bath cooling of large superconducting colls.

The posstbilfties of coolant path blockage or pup fallure are rellability concerns for a forced flow ryatem. Bath cooling on the other hand 1s Inhezently reliable so long as the colls remin fully incersed In liquid.

Accomodation of Plasma Neutron Radiation and Disruption Eiset Loads

For the STARFIRE design, suff telent high grade ahtelding will be interposed between the reacting plasen and TF-coil centerpost region to Limit total heat flux to cryogenically acceptable liates $(-30 \mathrm{kt}$ overall into the centerpost).

of far wore concern is the Inductive heat load deponited in the helfum cooled TF-coll mass by a plakpa disruption. (based upon considerations of operational rellabiltty and mintalnabllity, the present STARFIRE daster bes no stabilizing/disruption absorbing coile inboard of the plasmi.) Regardiess of the TE-coll craten configuration or component realetances, the cotel diexption energy

$$
E_{D}=\frac{\Delta B^{2}}{2 E_{a}} \cdot v .
$$

hace $\Delta B=1$ teala, and $\nabla$ is the coill/cryostat volues. For our IF-coll size, this wounts to about $500 \mathrm{MJ}$.

The question yet to be regolved in what fraction of this heat load can be absorbed by the cold ( $4 \mathrm{~K}$ ) ares sithout driving the coil nomal. The remaining fraction of the heat load can then hopefully be borne by the roon and $k_{2}$ temperature elements (vacuum tasik and therenl radiation shield), material and configuration callored as approprlate.

\section{Cotl Design}

Conductor configuration, cooling wethod, cryostent tructure, and coil design are of course intiately ineerrelated destign considerations. The essential fentures of the coll destgn are shown in the coll/ helfen reasel centerpost region cross-section, Fig. 6. The paracke (layer wound) colls ara wound directly onco the bobble, formed by the Inner radiue wall and radinl ceatral wo of the helium vassel. Primery coolant Elow cocurs between the coll layers, while the cabled conductor prorides channels for face, and conductor Ineeriel cooling. 


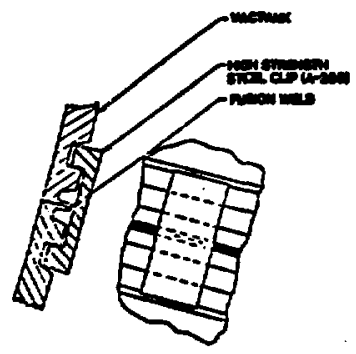

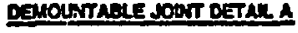

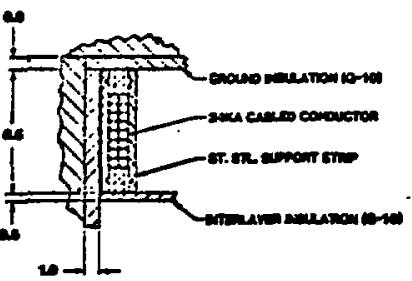

DTare

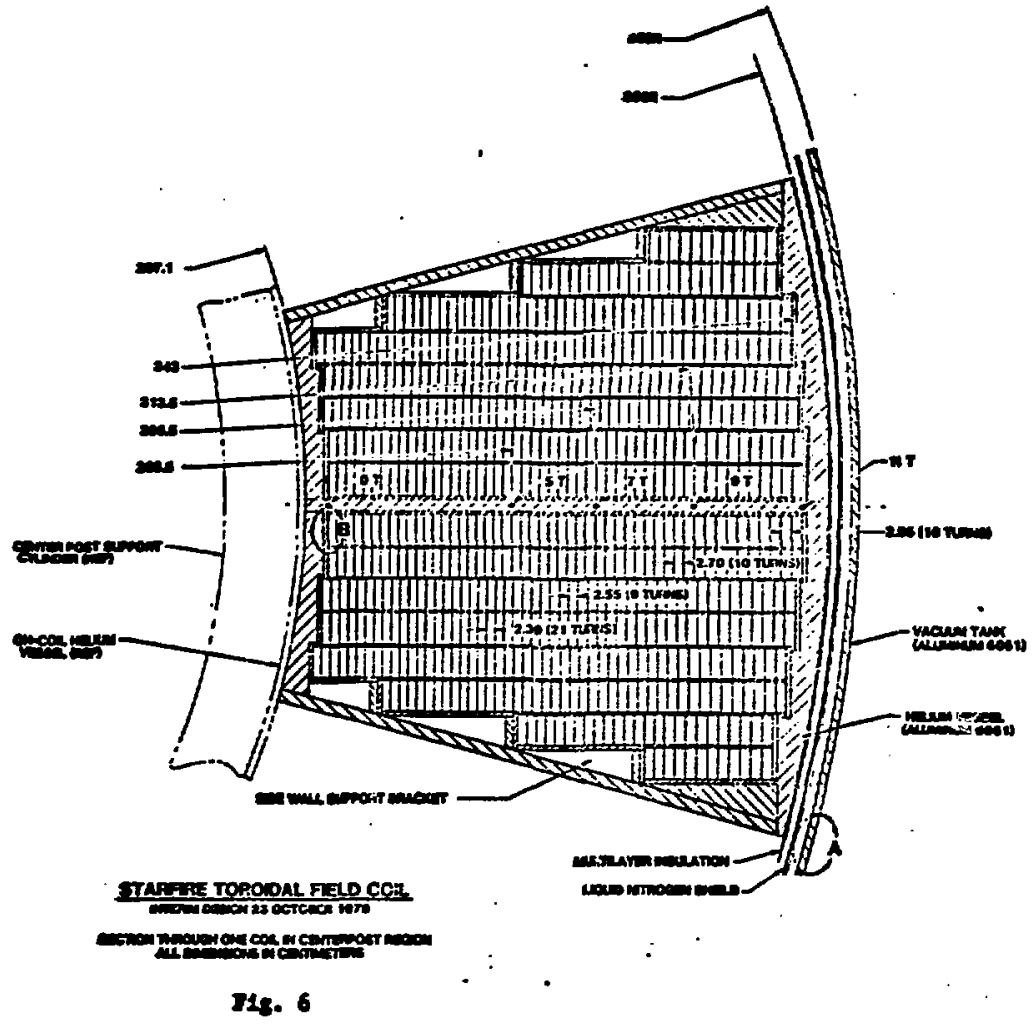

The structure required to support the coll/hellu vesen 1 units agelast out-of-plane (overturning) loads has not yet been Investigated, even conceptially. A tentaclve evaluation of the overturaing loads to be borne is thown in the accompanying F1g. 7, based upon employinent of external plasea equilibrium (EF-) colls.

\section{Sumary of Interim Design Parameters}

The bastc caiculated destga paraneters are armartas in the acconpanying Table 1.

TABLE 1

STANFIRE TF-COILS, CALCURATED RARAMETERS

The two dieadvantages of aluninu as a structural entertal for this application are 1ta low wodulus of elestefty and 1te relatively high coefficlent of thoral contrastion, compared to stalniess steel. Toush further investigation is required, these idntentlens do not appear to outuelght tho advancages of Iminu.

Ins II-coll helfun veasels share com cecum celosure, in the centerpost regton. The outer. curved cortion of each TF-coll hellun veasel is eurrounded by - Individual vecuum barrier. As abowa in F1g. 6, the vertical intercoil vactanic sean in the cencerpoet zeston are dest goed to atninize the diffeculty of rowites a coll/beliu veseel unit. stored energy: $67 \mathrm{GJ}$

- Total empere-turne: $189 \times 10^{6}$

- conterpont reglon. Coll/haliu reseal:

- Outer radius: $3.50 \mathrm{E}$ "

- Inanr redtus: $2.07=$

- Indial chlckness: $1.43=$

- Arerage curxent demity; $770 \mathrm{Ne}{ }^{2}$

- Toenl hest laed (12 colle)

- Inutzos: $-30 \mathrm{kd}$

- Rlana dincruption: $500 \mathrm{~kJ}$ (unshtelded) 


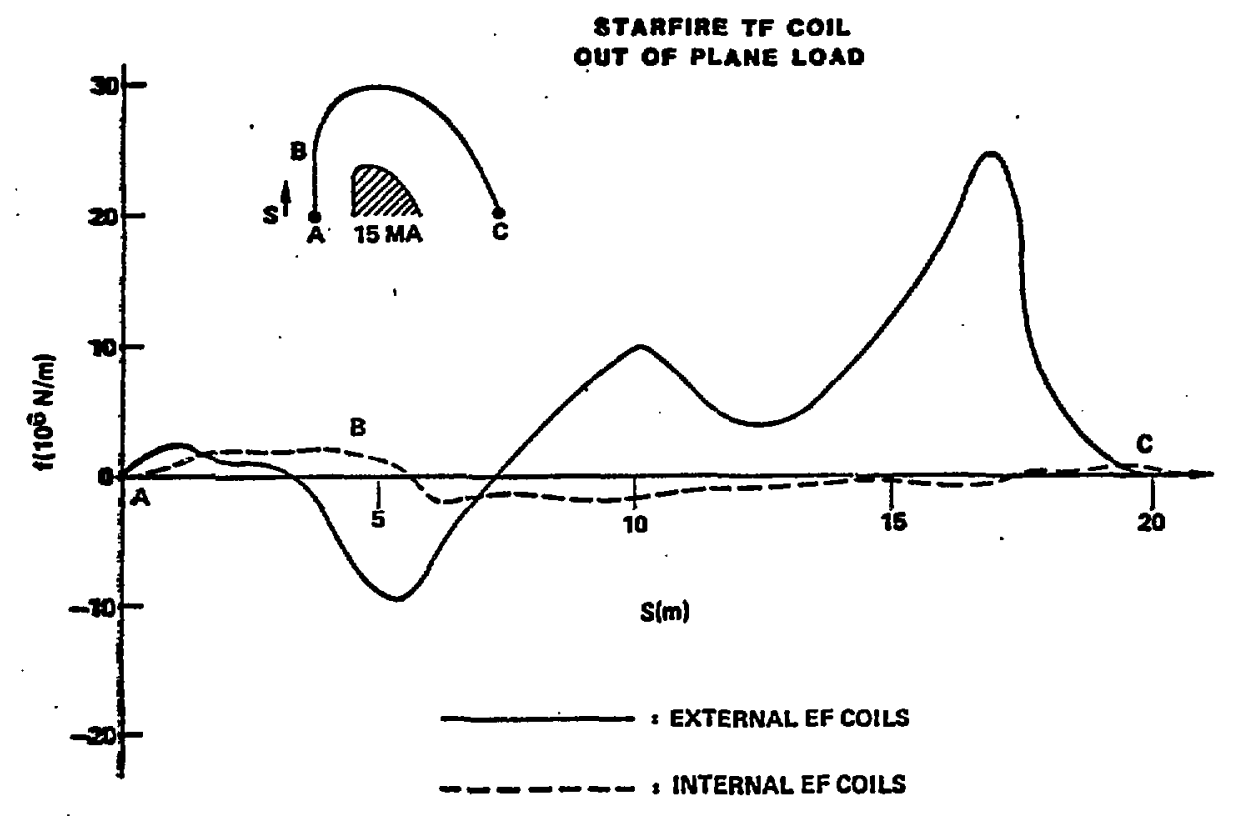

IIs. 7 . 


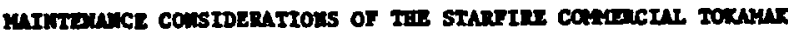

\author{
C. A. Trecheel, E. 5. Zsha, MeDonell Dougles Astronnut1es Compay - St. Lou1e, MLcourt \\ R. F. Fild, Geveral Atoric Company, Smo Diego, California \\ I. C. Steven, Argonne Bationel Leboratory, Argome, Illinole
}

Starim

An infter renctor design hes been developed for the Starfire Tokanak reactor that incorporaten anintenance features to peralt reactor and plant operation vith a 752 ava11ab111ty.

All components of the reactor can be replaced utflisiag highly autonated renote mintenance techafques. Provisions for contact waintenance are locluded but would only be ut1lized on a contingency basis alnce it 1a balleved that allowable doae rates w11 be decreased in future gears. A modular deelgn appraach 1a used for the reactor and auxillary subyotens to pernt efficlent use of rewote malntenance. The wodular approach alnimizes the number of dif ferent malntenance operations required and can result in use of sipple tasks auch as pusi, pull, turn, ete., ancuver for module removal. Faule 1soletion 1s provided for each replaceable sodule. When a reactor component falls the faule 1solation systen identifies the sodule that contalna the falled component. The odule is absequentiy removed and replaced with a pretested module. Detalled fault isolation and cowponent replacement or repair is performed in the hot cell where mora tire and equipaent is avallable.

The reactor design does not require any in-place munufacturing operations such as rewinding magnets in place and minfoizes any in-reactor welding operations.! Ho In-reactor velding is required for acheduled maintenance.

An Initial allocation of replacewent times and the reavitant component rellability requirements has been ade for the current utility malntenance acenario that $i$ ut1lizes scheduled annul shurdows of 1 wonth and a acheduled 4 wath shutdoun every tench year. These allocations establish requirements for malntenance equiprent and can be used to identify the need for redundancy. The 757 avallability goal in belleved to be achlevable if a four-year replacement cycle for the f1rat wall, blanket, 11miter and RF duct assembly can be utilized. Scheduled malntenance operation can not be permitted to shutdowa the renctor more than 1 time par year and in-reactor corponenta should be dealgaed a that acheduled replacement 1s not required more than 1 tine in two to four years. Auxiliary subaystea conponents outside of the reactor will be required to include redundancy that pernitu operation for at leset - Jenr or that permita replacenent during reactor operation.

\section{Introduction}

The malntenance approech for the staxise Cowarelal Tokanak 1a belng developed as part o: a DOE funded otudy to devalop a conceptual deatgn for a comercial tolungl rastor and belance of plant.

The primaxy conelderation in eninterince approach ealection is the plant avallability wich 1a the mads driver in daternining the cost of power produced. As iuch, major rexctor dealon decisione are being made based on mintenunce coralderatione. Design approachas: peratting rapid replecenent of life linited component. heve baen empestzed. All conponents, locluding the 11fe-of-plant iten auch os the TF and EF colls, are doptgned for raplecennt within tive 11 intes acceptable to the utellefes.
Inote entateneace io uaed for all operation Inside the reactor bullding because of the desire to intt radiation exponure to maintenance yorkers. Benefits of contact antenence till be aseessed at the end of the atudy.

I The firat wall and blanket ascembly (1ncluding conting and lintera) 1s expected to require the nost i frequent acheduled maintenance alace litele redundancy can be incorporated. Design studies reaulted in selection of a design that permits fault 1soletion to a toroldal sector and subequent resoval and replacerent. Subsequent repalra are made in at hot ceil. The hield aynten 1s Independent of the f1rat vall and blanket and, except for an acceas door, requires so scheduled mintenance.

This paper presents the gaintenance approuch, the comercial tokamak design festures that enhance maintenance and preliminary rcpair time and required wen-time-between-fallures for major subsyatems. Reactor hall bullding and malntenance equipment requirements lacluding hot cellg, coll rewinding and cranes are diacuased.

\section{Malntenance Approxch}

The renote anintenance ap: oach was chosen for in-reactor operations because of the likelihood that current regulatory radiation limits will be signific'antly reduced and because the reactor hall vill be exposed to tritium by permestion and releases during antenance of the coolant, fueling, vacuum and i tritium ystems. Some activation may also result frov i neutron otreaming, and particulate matter. Use of remote maintenance equipment w11l permit antentence with a intmel cool-down or clean-up period, and nay permit ome malntenance operations during reactor operation. Other factors Influenciag the choice of remote maintenance include: 1) remote mantenance w11 be required for ace1dent conditions, however 1t would not have to be as oophisticated, 2) remote technology will be avallable thiru currently planned programs (HEF, etc.) and 3) the bellef that for a properly designed machine, scheduled mafntenance can be perforwed wore rapidly thin persomel wulted for radiation protection.

The dealga philosophy being followed is to atniwize the radiation levela within the reactor buliding; to design all components for complete rewote wainteDence, and to 1dentify contact mintenunce operations where persoanel can afely be uaed wh algnificant econonic avinga. Enphas is ia being placed on designIng to perate rapid replacent of scheduled antatenemce iteo becauae starfire is ataund to erist in wature fusion econony where development work and operationel experience have reaulted in a predictuble reactor with appropr inte redundency and reasonable componeat rellability.

A11 components vith the resctor bulldins are replaceable. Some are replaced on a scheduled aninteance bate while othera are dealgned for the ilfe of the plant and are replaced only in the evant of fallure. Itens dealgned for the life or the plant laclude the overhead crane, IT colls, EP colla, coolat pipins, reactor aupport atructure and radiation ahieldIns. Tha blanket asatebly, Impurity coatrol conpon- 


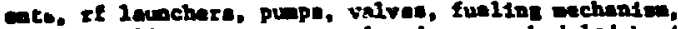
power aupplies, atc. are replaced on - echoduled basil, spara are provided for all componente with expected hiph fallure reten, wo that se ope part in removed a prateated raplaceent io avallable eo reector operatoo cen colmeace while rapalre to the danaged conpooente are belag aede. The opares for the oupercoaducting EF co110 trapped belou the IF colle are acored in place oo resctor diaseseubly $10 \mathrm{um}-$ acenery in event of a fallure. These colla are doetpined for life of plont but the consequence of thatr fallure augreste in place oparas are prudent.

The nuber of different wintenance operatione planned in the reactor bullding ere niniatzed by uolng a component "rewove and replece" opprosch. Th1 perates each enintenuce action to be preplanned and deelfued for use with imple pueh, pull, etc., operatione. Thio approach Increasea the confidence in the epeed of anterance operationa and simplifies aincenance equipment design requirements. Once the danged or end-of-11fe componente are renoved from the reactor they are transported to a hot cell where core time 1o avallable for sheckout, repalr or dispoenl. The hot cell will have extensive mintenance capabilicy for teating, component replacenent, cutting, velding, wachining, pinpoint leak location, and low-z costing repalr.

Redundapey is planned for reactor auxillary suburstems to perm1t continued operation of the plant unt11 a scheduled malatenance perlod or uatil the component can be replaced in-service. The particular cooponente where redundancy is planned will be defined et the design progresses; however, current plans Include redundant pover supplies, vacuum pumps, rf launchere, sone valves, pumps and fueling mechanlsas.

Avallabllity gouls have been establiahed as $75 \pi$ for the complete plant including the reactor. This reaulte in a 91 day per calendar year downtime. Allocations of permissible time-to-repair and timebetveen-fallures have been made for major subsystems to serve as a basis for design of the components and mintenance equipment. The maintenance scenario incorporates the current urllity practice of acheduling. hutdows annually for one month of malntenance and a 4 to 5 moneh ahutdown every 5 to 10 yesrs for turb tne repa1r.

The starfire reactor to being designed to confora! Ith this current utility practice, however, the ajor i ahutdow is assumed to occur only every 10 years and lant for 120 days ( 3 moatho). The comblnation of the annual and ten yenr shutdowns requires that 39 days of : domtime be allocated to scheduled malntenance. Current utility experfence with the balance of plant indicates that fallures result is approxinately 21 daye of unscheduled outage annually. This leavea 31 daya of unscheduled downtime that can be allowed for reactor subsystems. These allocations aname that both the balance of plant and renctor acheduled malntenances are performed in parallel while no overlap in scheduled and unscheduled naintenance is planned. $A$ ausang of these sllocectons is given below in Table I. It ohould be poted that a total of 52 daye per calendar year 1. -llocated to unscheduled mintensnce vhile only 39 deya 10 waed for acheduled matntenance even though wa have sected that wat outagas wil be the result of achedula shutdorne. Th1s is in agresient with the fact that, in generel, unscheduled fallurea will take longer to locate and repalr. Convenient preventat ive malntenance and repair of radundant componente in acheduled ae part of the enintenance ecenario durizs then unacheduld cotager.
Ioble 1. Yalotendace Scenar10

\begin{tabular}{|c|c|c|c|c|}
\hline \multirow[b]{2}{*}{$\begin{array}{c}\text { Outese } \\
\text { Type }\end{array}$} & \multicolumn{2}{|c|}{ galance of Plant } & \multicolumn{2}{|c|}{ Reacror } \\
\hline & Scheduled & Unacheduled & Scheduled & Unscheduled \\
\hline $\begin{array}{l}\text { Totel } \\
\text { Dowatinas } \\
\text { Alloce } \\
t 100 \\
(\mathrm{da} / \mathrm{x})\end{array}$ & 39 & 21 & 39 & 32 \\
\hline
\end{tabular}

*Ipcludas antenance equipment and auxillary reactor ayateme.

\section{Rector Minintenance Festuree}

The resctor dealon conflguretion to thowa is Figure 1. The deelgn van developed 20 all components could be replaced in the event of fatlure and fault inolation 1s provided to the replacement level so that anteal tias is required for identifyling a falled com ponent.

The design 1o belng developed to keep the top and ;ides of the reactor clear for accese by mantenance equipneat. Componenta are also belag combined shere - practical to minlolize the number of assemblies and Inprove access. Examples of comblned components in: clude; the TF coll roop-temperature devar provides atructural aupport for the EF colla and shield; and the shield providea the anti-torque frase and vacuun boundary.

The blanket 10 replaceable in 1/24 eectors of the torus. Each $1 / 24$ sector Incorporates an integral firat wall, 11miter, if duct and air bearing pad that 10 removed with the blanket. The coolant is manifolded through eeparate loops for each $1 / 24 \mathrm{ch}$ of the blenket to permit leak 1solation to individual sectors. The hellum coolant lines and the vater coolant lines to the $r f$ duct and 1 imiter utilize mechanical disconnecta. The life goal for limlter and rf duct 1a 4 years and the blanket 11 fe gosl 188 years. After four yeura the blanket sector is replaced. The used sector 1: refurbished in the hot cell by replacing the ifmiter, rf duct and low-z conting. Perlodic 1n-situ replacenent of the low- $z$ conting any 1100 be required.

Blankat sodule lenk detection w111 be accooplished by asquatially reducing the pressure in Individial blenket sectora and aonltoring the change of the partial pressure of helium in the plasens chamber with a gan andyzer. This technique requires valves that isolate sectors from the primary coolant loop. Leak detection of the 1 imfter first wall and rf launcher water syste will also rely on reduc1ng the syatem pressure of each sector sequentially and denoting changes in the detected leak rate. Leak detection of the shield aysten to the plasma chamber syaten w11l be accomplished by infecting helius into a cavity between radundant aeals. The blanket leak detection syatem 1a dependent on the particuler design that 1a developed and will be modified an aeceasary.

The ahiold In deniged to lant the life-of-plant and w11 be repleced only in event of unecheduled fallures. A ehield door is provided that perrite access to the blanket. The door is sealed with redundant eni with interiadiate puping, that are abielda lockl1s to reduce the radiation danage. The seals are repleced wech tine the door la opened. The basic ahleld conelete of aectore walded together to fora the vacuu boundery. cuteing and revelding the polatdal eale io requited if ahield anctor replecenent is required. scees to the velat is from the ah1eld interlor and a parenent velder/cutter track 10 


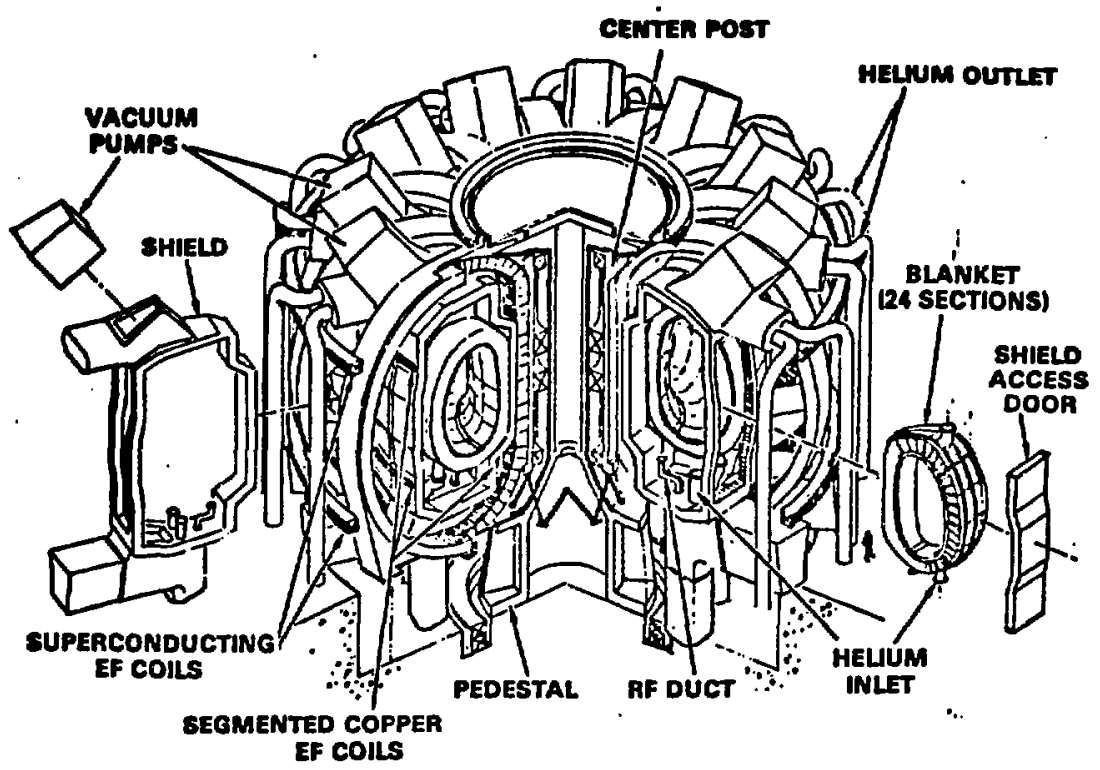

Figure 1. Starfire Renctor Daniga

Installed at each joint. The modular deatgn of the ohleld is shown in Figure 2. Redundant vealo are provided at each joint to permit leak teeting.

The If collo are also life-of-plant components. They utilize a comon velded deuar in the center post region. Coll replecement time 10 not algnificanty impacted by the welded dewar. A permanent welder/ cutter track 1c aloo installed at this jolnt. ArinealIns of the TF co11 1a planned every 10 years to reduce the effects of radiation damage in the atabilizer.
The EF colle are lso 11fe-of-plant. EF colls Inside the TF coll are copper and are segmented to peralt removal. An elevation system is rovided to raise and lower the outer colls for access to the blanket. The external EF coll are superconducting. Those on the top and sides of the reactor can be removed for replacement. Spare EF colls are provided for those trapped belou the TF colls. In event of fallure the coil is cut out and the spate raised into poaition.

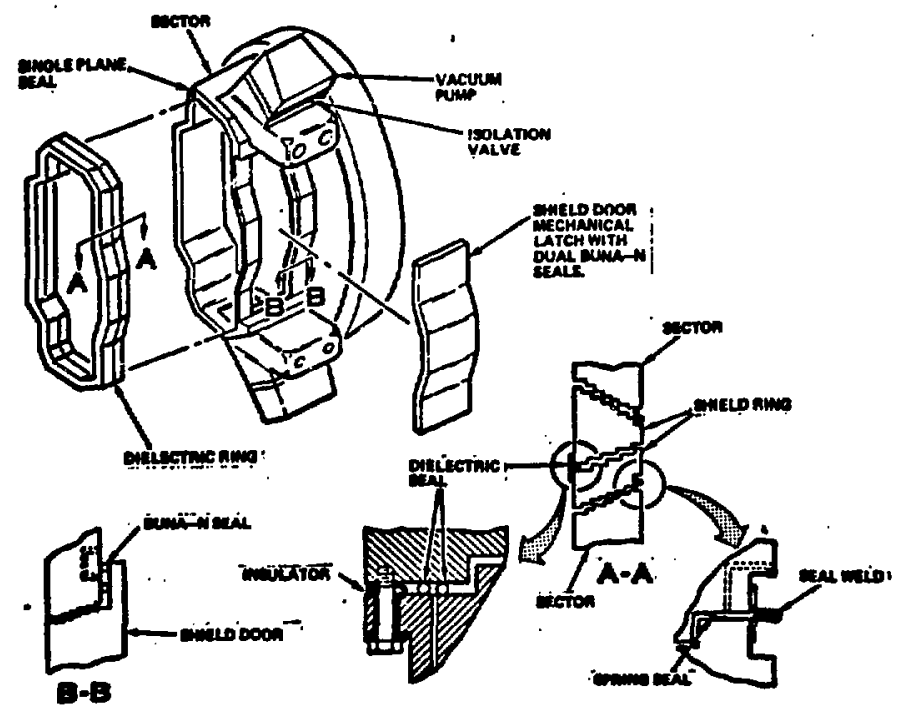

Truse 2. Shicld Daston 


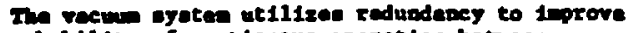
the probability of continuous operation between celoduled welocenance perlodn. Tuenty-four eryosorp clon purpe with isolation valves are provided of which, eproxinately 20 are required for operat10a. Ixternal valves and pups leading to the tritiw procesales crate ut111 ze redundunes.

The power supplies are atauned fully reduadant and Include replacement capability during operation. The power supply ayatens are located outslde the printry confinenent bulldins and can be repalred durIns plant operation.

Ta1led radundant heat traneport aystem componenta, vith exception of a faw In-liae valvas, can be repleced durins reactor operation ualng renote/hande-on ententenance equipaent.

\section{Reector Bulldins Melptenence Funct lone}

A preintary lieting of scheduled maintenance functions 10 provided in Table 2 . The number of acheduled actions at the reactor 1sland have beea held to a etnioun. The schaduled maintenance function of the auxiliary systems can, in part, be done during resctor operations.

The planned unscheduled anfatenance functions include all component assemb11es making up the reactor. The uncheduled tters are shown in Table 3. Both tables 2 and 3 will be updated a the deatgo progranes: and the subsystem are better defined.

Table 2. Scheduled Malntenance Funntions

\section{Renctor Island}

- Shield door neal replecenent

- rf veve guide wiadou replacement

- Blanket nector replacement

- Vecuus pump/1solation valve replacenent

- Fuoling oystem replacement

- IF coll annealing

\section{Aux111ary Reactor Subsystens}

- Coolane loops

- valve replacement

- puep replacement

- Power ayatem

- electrical witch replacement

- electrical energy atorage component replecement

- power conversion oyutem replacenent

- Malntenance equipment replacenent

- Tritiln processing

Table 3. Unscheduled Maintenance Functions (axcludins echeduled enintenance funct 10ne)

- Power. Iend replacement

- Coolant IIne replacenent

- leat exchenger replacenent

IT coll replacenent

iT coll replacenent

shleld replecenent/repalr

\section{Lot cell Operatlons}

The function planned in the hot cell are liated 1. Tabie 4

\section{Iab1e 4. Hot Cell Functions}

- Cospodeat testios

- vecur integrity

- electrical function

- configurat Ion

- Lenirage

- Ropalr

- euterine

- weldins

- achining

- clenning

- Reactor retrafit

- blanket

- Iinter replacement

- If launcher raplacement

- lorm coating replacement

- module replacement

- tritium procesalog syatem

- vaculm oyatern

- coolnat eget ens.

- cryogenic aystems

- powar eysten

- Haincenance equipent

- Decontanination/disposal

\section{Mintenance Time Allocatlone}

A proliminary ligeling of the echeduled malatenance actions is shown in Table 5 . The assumad critical patb 1. show with the preaumption that all other mainteance ections can be accomplithed in parallel operetlon. Th1s 11sting will be updated as the program progreasea. An increase in the number of items in the critical path can have signlficant Impact on achieving our ocheduled maincenance goals and would require a decrease in the replacement time. If subsequent analyals of the 11fe of blanket module cooponente (1.e., 11miters) Indicate 11ves less than 4 yeare, other watenance concepts which permit replacement without blanket removal w11l be required.

The unacheduled malntenance 1tew listing is show In Table 6. The velues shown for Mean-T 1me-To-Replace (IITR) are ansuned valuee baned on past atudies. The average downtire per year to then assigned to each subsyaten beaed on the percelved relative rellability and conplexity of eech cubsystem. The result is a permasble fallure rate per calendar year. These values can then be ueed by subuystem designers to deflne the redundancy and design marg in requiremente for the suboyoteme. An accurate asseanent of the actual follure retes can only be derfved after nubystems are deffned w to the number of couponents, redundency provielons, ; the trpee of fallure modes and fallure rate per fallure mode have been eatablished. Our program will utilize historical date where possible to anese feasibility of meeting the requirements of Table 6. $A$ conclualon that can be drawn after roview of the table to that the tine required for husdown and atartup wut be kapt to a minimu (2 daye or less) to prevent uafos a large percentage of the unacheduled dountian eiply to reatart the burn.

\section{Mantenance Facility}

The selection of the "renove and replace" and "ful1y reate" aintenance appronchee resulte in a zather large alpteruace facility. The firat iteration in a facility layout to nustain the need of + sormal antanace has reoulted in a facility that 
Table S. Sebeluled gingtoncree

\begin{tabular}{|c|c|c|c|c|}
\hline Aetson & $\begin{array}{l}\text { Frequency } \\
\text { (vr) }\end{array}$ & $\begin{array}{l}\text { Replaced/ } \\
\text { Outage } \\
\text { (2) }\end{array}$ & $\begin{array}{l}\text { Tine-to- } \\
\text { Replace } \\
\text { (daye) }\end{array}$ & $\begin{array}{c}\text { Critical } \\
\text { Path }\end{array}$ \\
\hline 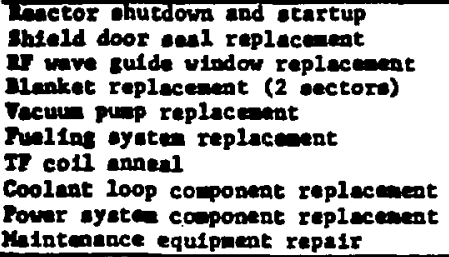 & 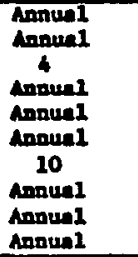 & $\begin{array}{r}2 / A \\
25 \\
25 \\
25 \\
16 \\
25 \\
100 \\
25 \\
50 \\
1 / A\end{array}$ & $\begin{array}{r}2 \\
2 \\
6 \\
20 \\
6 \\
6 \\
<120 \\
14 \\
14 \\
x / 4\end{array}$ & $\begin{array}{l}* \\
* \\
* \\
\text { (1) }\end{array}$ \\
\hline
\end{tabular}

- These operations met be done aequentially, other operations are aenuned to be parforned durins the critical path tive frage.

(1) Comptible wth 10-Jr shutdown for 16 to 20 veeke for turbine repair.

covers sone 2000 to $2500 \mathrm{~m}^{2}$ of floor area. The enjor features of the facllity are described as follows:

$$
\begin{aligned}
& 2 \text { - Large component disaseerbly cells, } \\
& 12=t a 11 \times 12=\times 6= \\
& 2 \text { - anal1 component repair cella, } \\
& 4=\operatorname{tall} \times 10=6 \text {. } \\
& 1 \text { - Storage bey (3 levels deep), } \\
& 16 \text { vide } \times 18=\text { long } \times 20 \text { m deep } \\
& 2 \text { - Reactor hall aervice entrances, } \\
& 10=\operatorname{tall} \times 6=\text { wide }
\end{aligned}
$$

These facilitiea are supplemented with intarconnecting corridora, hielded wall and doore, equipant stag1ng areas, equipant atorage and repair, and hot cell operational arean. Addit Lonally these facilities are equipped with cranes, hot cell windows and anipulatora, 11ghting service/repair equipment and decontaninetion equipoent. Scheduled functions covered with these foclilites are:

1. Blanket Sector, Including servicing of corponent connectors, seals, upport structure and eenwors. The enfor componente are:

\section{- Inicer.}

- Firat vall panela

- Lou 2 coating

- Blanket modulea

- Nr erille and extansions

\section{Vecuup punpe (scheduled replacenent)}

3. Shielding Sections (Unscheduled replecreent)

Other components auch as Klystrons (Benerator) launcher), coolant plping, vacuua, cryogentic and electrical connectora, structural members, etc. are of - leaser radiation probler and are handled in a secoad order antetenence category with aeparate equipsent.

Major unscheduled mintenance operations have been considered for shield section, EF coll and IF coll replacement. Equipment will be provided even though they are des 1 gned for the 11fe-of-plant.

A proposed matenance facility layout is ahorn in Figure 3.

The layout show the dual entrance to the reactor bullding through which the blanket rectore wil eravel. Each wil have in ante-chamber for decontaniaation/ isolation. Corridors conpect the entrance with the two malo dinansembly cella, otorage vault and outer equipaent ares. The smilier hot cells for flrst wall, blanket module, RF grille and vacuus pump melntenance are alno attached to the corridor detwork to attein a cooth flow during multiple matenance operations.

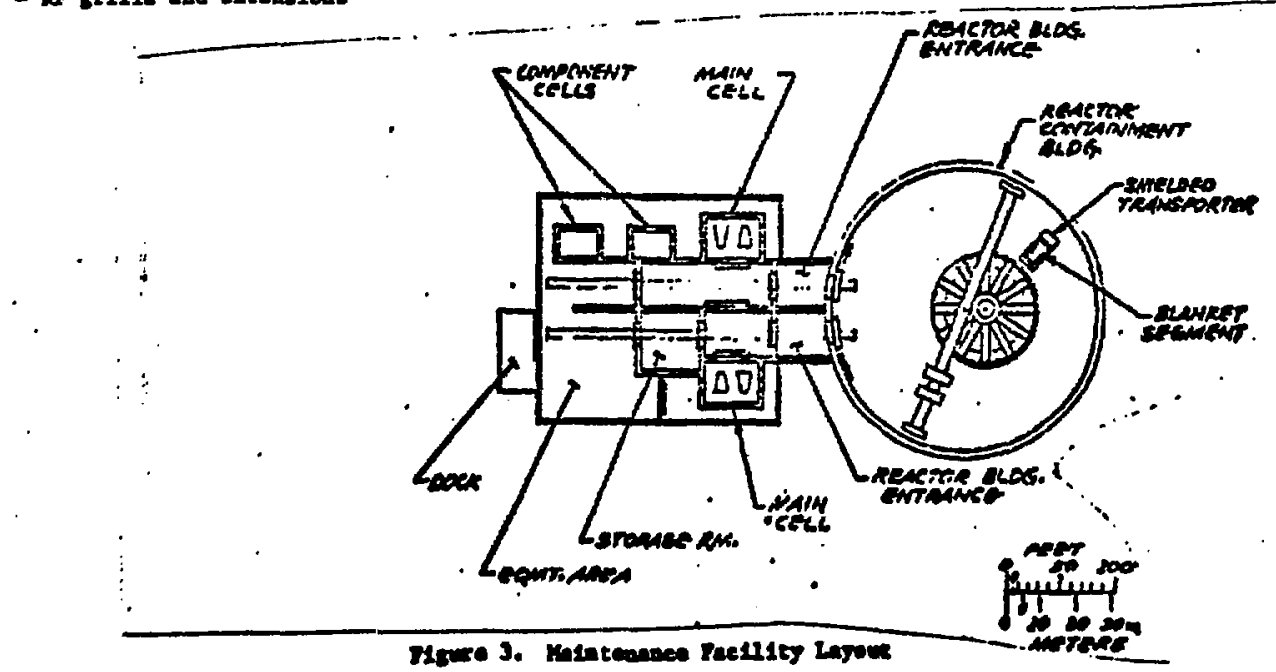




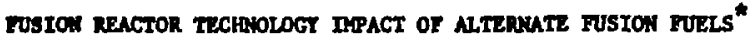

\author{
C. C. Baker, A. Bolon, "k. Clewer, K. Evans, Jr., \\ J. Jung, D. Satth, L. Turner \\ Argonne National Laboratory \\ Argonne, Illinot: 60439 \\ T. Blue, J. DeVenux, D. Drlemeyer, J. Matzgar, \\ G. Miley, H. Tetley \\ Uafveratty of Illinoto \\ Urbane, Illinois 61801
}

\section{Sumpry}

The Intelal results of a study carried out to estese some of the technology implications of non-D-T funton fuel cycles are presented. The primary emphasis In this paper is on $D-D$, catalyzed-D and $D-{ }^{3}$ He fuel cycles. Tokamaks and fleld-reverged mirrors have been alected as sample confinement concepts. The technology areas considered Include first wall design considerations, shielding requirements, fuel cycle requiremente and some safety and environmental con-iderations. Conclusions resulting from the study are also presented.

\section{Introduction}

Th1s paper describes the reaults of an Initial -tudy to assess some of the fusion reactor technology requirements of so-called "advanced" fusion fuels. In this paper, "advanced Euelg" refer to any alternate fuston fuel cycle compared to the deuteriumtritlum-11thium fuel cycle. The basic approach of the study was to develop representative parameters for the distribution of reactor power into neutrons, charged particles and electromagnetfc radiation for two aample confirement concepts. These power split distributions were then used to examine some key reactor technology areas such as first wall design considerations, shielding requirements, environmental Impact of activated materials, and fuel cycle degign considerations.

\section{Puel Cycles and Confinement Cancepts}

$A$ varlety of elements other than deuterfum and tritfuw can undergo fusion; prominent examples include $D-D, D-{ }^{3} \mathrm{He},{ }^{3} \mathrm{He}-{ }^{3} \mathrm{He}, \mathrm{p}-{ }^{6} L 1, \mathrm{p}-{ }^{7} \mathrm{~L} 1, \mathrm{D}-6 ! 1$, and $\mathrm{p}-11_{\mathrm{B}}$. These fuels have, in varying degree, the generic features of reduced neutron production, increased fualon energy carried by chareed particles, and the cilsination of a need for tritium breeding. On the other hand, the combination of lower cross sections, higher plasma temperature, lack of avallability of wowe fuels ( ${ }^{3} \mathrm{He}$ ), and Increased radiation losses make efficient confirement (1,e., high energy multiplication) more difficult. A key consideration then 1a whether or not the dvantage are indeed oufficlent to justify the development of alternate fuel power plante. A quantitative evaluation of the technology involved muet be undertaken.

Deuterfum-baced fuele have the advantage of operating at relativaly low temperatures but involve wre neutron and tritium production via "alde" D-D reaction. Lower temperature deuterium based fuels, balns easier to burn, are compatibla with a wide range of confinement concepte; for exapla, toknmakn could

\footnotetext{
Fork supported by the U.S. Dapartant of Enargy. the On Iesve from the Untveralty of Mineour1 - Rolle.
}

burn catalyzed deuterium and D-3 He. (Catalyzed deuterfum refers to burning deuterlum such that the reaction products of tritium and ${ }^{3} \mathrm{He}$ are also burned at a rate equal to 1 ts birth rate. The resulting. energy release allows operation at lower tenperatures.) But, unfortunately, the attribute of "cleanliness" is not as fully achieved in the deuterium-based fuels as the more-1deal proton-based fuels. The proton fuels, on the other hand, due to a combination of the high temperature required and modest energy released per reaction, appear much harder to successfully burn, forcing the use of more advanced confinement epproaches.

In order to study "representative" combinations that are 1llustrative of a wide variety of possible combinations, we have selected for study a matrix of alternate fuels along with a modest and h1gh $\beta$ confinement systems. Since catalyzed-D is the only "self aufficient" (only requires naturally avallable deuterium) low-temperature fuel, it 1 s selected as the base fuel. However, due to itg potential attractiveness, $D-{ }^{3} \mathrm{He} 19$ also considered despite the complication of ${ }^{3} \mathrm{He}$ breeding. Since tokamaks are presently the most highly developed confinement oystem, and since they (or at least modest $\beta$ versions) can burn these low temperature fuels, they are selected as a representative modest $B(10-20 \%)$ confinement system. (These $B$ values are about a factor of two larger than predicted by most current theorles, but are considered to be reasonable extrapolations for purpose of the study.) Concurrently, the Fleld-Reversed Mirror (FRM) is selected as a representative high-B (> 70\%) device. Th1s to acceptable for the low-temperature fuels, but may not be adequate for the higher temperature fuels where even more innovative confinement approaches such as Surmac may be neceasary.

\section{Plana Engineering Considerations}

This section summarizes some of the plasma eng1neering considerations of this study. Included is a brief review of the key features of example tokamak and FRH devices for alternate fuels, as well as thelr power splits.

Toleamaks

The tokamak seta a reference standard and provides a good basis for comparison of $D-T$ and 10 wtemperaturas alternate fuel technology. As a part of the present study, we have evaluated the characteristics of alternate fuel tokamaks in $11 \mathrm{ght}$ of confinement scaling lawt based on recent experimenta, e.8. empirical energy scaling baaed on PLT exporiments and on Alcator data. For example, with $B=10 \%, 1 \mathrm{~g}^{-}$ nited catalyzed deuterium and $D-3$ He tokamike are approximately one-fourth the volune for Alcator acaling wopposed to trapped Ion scaling. While these new renults are at111 uncertain due to uncertaintiea about the accuracy of $\mathrm{nt}$ aceling at the high temperatures involved (30-40 kev), they demanatrate a plaustble advanced-fuel tokamak approech. As an eximple, an 
Ignited cat-D toknak using Alcator ecaling with = $10 \%$ and $\mathrm{B}_{0}-0.7 \mathrm{~T}$ would have a eajor radius of 12 a and a afnor redius of 4 m; the tharmal power level 10 approxtentely 7900 pis.

An edvanced fuel tokank reactor w111 require toroldel wenetic fleldu and plane currente larger than those conterplated in design studies for D-T tokenak reactors. The piagni current requires a lerge llux mins in the ohmlc-heating (OH) coll systen to Initlate and suntain the plasma current. With NbTI ouperconducting OH colls, which will probably be 1inted to a field swing of $\leq 8 \mathrm{~T}$, the required erea within the OH solenoid is roughly proportioned to the dealred plasma current. Simllarly, a high toroldal field requires thick superconducting TF colla. As the central support cylinder and coll thickneas increase, the radius of curvature of the coll Increasen, which demands even more support and an even larger coll.

\section{A quentitative estimate of these considerations} he been underteken, uning the magnet model developed at ANL. Figure 1 shows the combinations of plasma current and maximum toroldal fleld at the inboard $\mathrm{leg}$ of the coll that can be obtained for different major rad11 of the tokarak. The reactor was asaumed to have an aspect ratio of 3 , a burn time of 3 minutes, and inborsd and outboard blanket and shield thiskness of $0.7 \mathrm{~m}$. The TF coll was assuped to operate at $4.2 \mathrm{~K}$ and to have copper stabllizer and stainless steel support enter1al. The OH solenold was assumed to have a magnetic fleld limit of $\pm 8 \mathrm{~T}$ and a current density of $1000 \mathrm{~A} / \mathrm{cm}^{2}$. No particular superconductor was assuned. The range of peak fields at the conductor is 12 to $20 \mathrm{~T}$. Thi. entire range for the TF magnet 1s above the fleld productble with WBT, and the upper half of it is above the field achlevable with $\mathrm{Mb}_{3} \mathrm{Sn}$. The f1gure is intended to show the constraints on plasma currents and toroldal field, Independent of the cholce of auperconductor. This anclyais is intended to establish the engineering relationships between the allowed limits of the toroldal fleld, plasula current and reactor pajor radius. It is not a phyolcs operating point (for exasple, physics constraints on the stablity factor. q. have not been considered), but rather serves as a gutde for establishing the possible range of high fleld

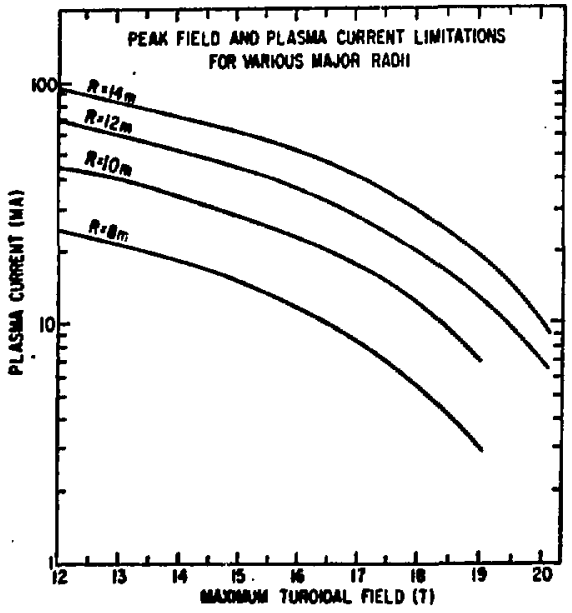

I1. 1. Maxinu placan curreot and toroldal flelds for altermate fuel tolmak reectors. tokanak derices. Conuldering rasonable ranges of the aximun toroidal field and plasme current, anfor redis leav than 12 meters are 11kely.

\section{Fle1d-Revereed MArrors (FRM)}

The FFA has been chosen as representative of h1 gh-beta devices for advanced fuels. H1 gh-bete devices are especially appropriate for advanced fuels because high $B$ operation can partially compensate for the owaller reactivities of advanced fuels. High- $\beta$ operation also decreases the cyclotron power enfted per unit volume, and $1 t$ aloo leads to increased reabsorption of cyclotron radiation. Consequently, advanced fuel FRM's have for the1r fuel and teaperature of operation relatively stall power loes due to cyclotron radiation. For most energy loss mechanisns, the energy confinement time generally increages as gize of a plasma Increases. Thus, the plasma multiplication can be Increased simply by increasing the size of the ayatem. Unfortunately, stajlity considerations 11m1t the radius of the FRM to a few Ion gyrorad11. Therefore, the advanced fuel FRM's are not 1gnited reactors. However, despite thelr smal. olze, the $Q$ values of the advanced fuel FRM's are substantial due to the assumed near-classical diffusion in the closed field region. Thus, advanced fuel FRM's can be categorfzed as small. efficient reactors with relatively large power densitles and moderate $Q$.

\section{Typical Power Splits}

The power splits are affected by fuel cycle, plasma temperature, plasma density ( $B$ and magnetic field strength), plasma size and plagma confinement scsilng. Table I presents the power aplits for the reference semi-catalyzed D, fully catalyzed $D$, and $D-{ }^{3}$ He tokamaks. Note that the fraction of power 1n neutrons 1s less by almost an order of magnitude for $D-{ }^{3}$ He than for semi-catalyzed $D$. The fraction of power in neutrons lo legs by about $10 \%$ for fullycatalyzed $D$ than for sem--catalyzed $D$. This $1 s$, of course, because the fusion product ${ }^{3}$ He 18 burned in the fully-catalyzed $D$ reactor.

The relationahips among the relative power fractions for the fuel cycles are not much different for the FMM than for the tokamak, aa is alao 1llustrated in Table Table I.

Table I. Power Splits for Tokamaks and FRMo

\begin{tabular}{|c|c|c|c|}
\hline \multirow[b]{2}{*}{ Power splite (z) } & \multicolumn{3}{|c|}{ Power Splits for Tokamaka } \\
\hline & Sem1-Cat-D & Cat $-D$ & $\mathrm{D}-{ }^{3} \mathrm{He}$ \\
\hline $\begin{array}{l}\text { Leaking Particlee } \\
\text { Bremastrahlung } \\
\text { Cyclotron Radiation } \\
\text { Reutrons }\end{array}$ & $\begin{array}{l}.20 \\
.26 \\
.11 \\
.43\end{array}$ & $\begin{array}{l}.26 \\
.25 \\
.11 \\
.38\end{array}$ & $\begin{array}{l}.33 \\
.46 \\
.16 \\
.05\end{array}$ \\
\hline \multirow[b]{2}{*}{ Power Splite (z) } & \multicolumn{3}{|c|}{ Power Splite for FRYa } \\
\hline & Cat-D & \multicolumn{2}{|r|}{$\mathrm{D}-{ }^{3} \mathrm{He}$} \\
\hline $\begin{array}{l}\text { Leaking Particles } \\
\text { Charged Fueion Producta } \\
\text { Dremotrahlung } \\
\text { Gyclotron Radiation } \\
\text { Geutrons }\end{array}$ & $\begin{array}{l}.25 \\
.19 \\
.18 \\
.03 \\
.35\end{array}$ & \multicolumn{2}{|r|}{$\begin{array}{l}.24 \\
.39 \\
.26 \\
.08 \\
.03\end{array}$} \\
\hline
\end{tabular}


Tor purposes of technology considerations discused In the next section, the most important parasater 10 the traction of total power carried by beutrons. This 1s relatively constant for the various cases discuased above, thus it 1o posalble to exanine certain firet wall/blanket/shield problems without apecifying a particular type of device. This 1s the generel approach taken in the next section when the fuel cycles are characterized in terms of neutron power fractions by the following repreaentative valuen:

$$
\begin{array}{ll}
D-T & \sim 807 \\
D-D & \sim 407 \\
\text { Cat D-D } & \sim 407 \\
D-3 R \text { R } & \sim 17
\end{array}
$$

\section{Technology Considerations}

This section describes sone key technology con-1derations of alternate fusion fuel cycles including firat wall design considerations, shlelding requirements, fuel cycle considerations and environmental conelderations of activation products and tritlum handling.

\section{Materisls and First-ila1l Cong1derationg}

An analysis of the 1mpact of alternate fuel cycles on materials selection and deaign considerations for the first-wall system has been carried out. The Inveotigation has focused on: (1) 1imitations of the energy deposition on the surface of the first wall, (2) oputtering and erosion of the first wall by plasma perticles, and (3) the Importance of ftrst-wall surface erphology on the reflectivity of cyclotron radiation.

An Important criterion in the degign of the first wall for a D-T fueled reactor is the ability to withthand the high heat fluxes deposited on the surface of the first-wall system. In a D-T fueled reactor that operates without a divertor, transport and radiation heat loads equivalent to approximately $25 \%$ of the neutron wall loading are deposited in the surface regions of the first-wall system. Based on the estimeted power splits given in Table II for $D-T, D-D$, and $D-{ }^{3}$ He fuel cycles, the total allowable wall loading has been calculated for a maximum surface heat flux of 0.6 1w/ $/ \mathrm{m}^{2}$. Th1s value was established as the design $11 \mathrm{mit}$ for a reference stainless steel first wall of a $D-T$ fueled reactor. As indicated in the table, the total wall loadings for the $D-D$ and $D-{ }^{3}$ He fuel cyclea are conaderably less than that for the D-T fuel cycle if allowable surface heat flux is a limiting criterion.

Phyolcal sputtering of the first-wall materilals has been Identified as a mafor inpurity source for a $D-T$ plasma. In general, the sputtering source term for D-T reactor analyses have been based on sputtering ylelda for a characteristic edge temperature, typically 50-1000 iv. If the characteristic edge temperature for an alternate fuel cycle 1s higher than that for a D-T cycle because of the higher plasm central temperature, the oputtering yields for most wall materials will increase. The 1mportance of any increase is dependent c: the affact of the Impurity on tha plasma performance. Since the sputtering yieids are produced priarily by the fuel 1ons, the mussea of the fuel tons are important. For the same fon flux to the wa11. the D-D fuel should produce a slightly lover Fifld then $D-I$, whereas the $D-{ }^{3}$ He ahould produce a of mifiently higher yield because of the higher wase of "He. Other fuel cycles with h18her mase 10ns wuld produce corraspondingly higher eputering ylelda for the same incident flux.
Table II. Comparison of Power Splits and Allowable Well Loadings for Alternate Fuel Cycles

\begin{tabular}{lrrc}
\hline Power Split $(X)$ & $D-T$ & $D-D$ & $D-{ }^{3}$ He \\
\hline Neutrons & 80 & 38 & 5 \\
Radiation & 8 & 35 & 63 \\
Tranoport & 12 & 26 & 32
\end{tabular}

Total Wall Loading

$\begin{array}{lllll}\left.(\max )=0.6 \mathrm{MH} / \mathrm{m}^{2}\right) & 3.0 & 0.97 & 0.63\end{array}$

The aurface morphology of the first wall is important since the reflectivity of the cyclotron radiation from the wall will affect the plasma energy balance. Although data for apecific condtions anticipated are $11 \mathrm{mited}$ and further work is warranted, some general observations can be made. Macroscoplc surface roughness, for example that caused by blistering, ohould not significantly affect the reflectivity of the relatively short wave-length cyclotron radiation. In general, the electronic structure of retallic surfaces should provide superlor reflectivity compared to that of insulators. Th1s property may be important in the selection of viable first wall matertals.

\section{Neutronics Artalysis}

The nuclear analysis is orfented toward identifyIng the design irupact of alternate fuel cycles in terms of (1) firgt wall/blanket nuclear performance, (2) reactor shielding performance, and (3) environmental effect.

Table III compares nuclear response rates in the first wall for the following four fuel systems: breeding DT(DT70/DT60), nonbreeding DT(DTO0), cat-D and $D-3 \mathrm{He}$. It is found that the cat-D systems yield relatively high nuclear heating and atomic displacement rates when compared to the $D-T$ systems that have a neutron wall load as much as twice that of the cat-D system. On the other hand, the radiation damage due to gas production is more severe in D-T systens because the associated damage cross sections have high threshold energies, so that the damage processea are very gensitive to the source neutron energles. There 10 aubstantially smaller radiation damage burden on the firgt wall in the lean-D-3 He systems. In particular, the gas production rates in the $D-{ }^{3}$ He systems are reduced by more than two-fold relative to the $D-T$ systems.

F1gura 2 shows the variation of the nuclear dose In an epoxy-basa magnet Inaulator as a function of the bulk shield thickness for the four candidate fual aystems. The dose varfation is represented as a plant lifetime in terms of $\mathrm{MW}-\mathrm{yr} / \mathrm{m}^{2}$ of the total integral wall load. The dose 11 mit criterion assumed is $5 \times 10^{9}$ red in the insulator. As an example, for a total wall loading of $1 \mathrm{~kW} / \mathrm{m}^{2}$ and a 30 year lifetime, D- ${ }^{3}$ He case would require about $70 \mathrm{~cm}$ of ahielding compared to about $I$ meter for the cat-D and nonbreeding $D-T$ case. $A$ D-T braeding blanket with ahleld would be about 1.5 meters thick.

21gure 3 represents another aspact of the deien lepect of the different fuel cycle eyatene. bown in the rigure is the blological herard due to 
Table III. Wuclear Radiation Regponce Rates at the Firet vell

\begin{tabular}{|c|c|c|c|c|c|}
\hline & & \multicolumn{4}{|c|}{ Fuel cycle } \\
\hline & & Dr70/60 & DTO0 & Cat-D & $\mathrm{D}-{ }^{3} \mathrm{He}$ \\
\hline \multirow{2}{*}{\multicolumn{2}{|c|}{$\begin{array}{l}\text { Total wall Load }\left(\mathrm{m} / \mathrm{a}^{2}\right) \\
\text { Heutron Wall Lond }\left(\mathrm{m} / \mathrm{m}^{2}\right)\end{array}$}} & 1.0 & 1.0 & 1.0 & 1.0 \\
\hline & & 0.8 & 0.8 & 0.4 & 0.01 \\
\hline \multicolumn{6}{|l|}{ Muclear Heating $\left(\mathrm{MN} / \mathrm{m}^{3}\right)$} \\
\hline \multirow[t]{3}{*}{ Type 316 Stalnless Steel } & Neutton & 3.66 & 3.62 & 1.73 & 0.041 \\
\hline & Gang & 5.08 & 7.28 & 4.25 & 0.126 \\
\hline & Total & 8.74 & 10.90 & 5.98 & 0.166 \\
\hline \multirow[t]{3}{*}{$\nabla-15 C r-5 T 1$ Alloy } & Meutron & 1.58 & 1.80 & 1.00 & 0.028 \\
\hline & Ganma & 2.68 & 4.30 & 2.76 & 0.088 \\
\hline & Total & 4.26 & 6.10 & $3 . \therefore 6$ & 0.117 \\
\hline \multirow[t]{3}{*}{ T16381" Alloy } & Neutron & 1.57 & 1.66 & 0.87 & 0.023 \\
\hline & Gavense & 2.34 & 3.49 & 1.89 & 0.052 \\
\hline & Total & 3.91 & 5.15 & 2.76 & 0.075 \\
\hline \multicolumn{6}{|l|}{ Gan Production (appo/yr) } \\
\hline \multirow[t]{2}{*}{ Type 316 stainless Steel } & Hydrogen & 451 & 427 & 190 & 4.0 \\
\hline & Hel1um & 122 & 117 & 50 & 1.0 \\
\hline \multirow[t]{2}{*}{$\nabla-15 C r-5 T 1$ Alloy } & Hydrogen & 214 & 205 & 87 & 1.7 \\
\hline & Heliun & 50 & 49 & 21 & 0.4 \\
\hline \multirow[t]{2}{*}{ T14381* Alloy } & Bydrogen & 174 & 169 & 72 & 1.4 \\
\hline & Helfun & 107 & 105 & 45 & 0.9 \\
\hline \multicolumn{6}{|l|}{ Atomile Displacenent (dpa/yr) } \\
\hline \multirow{2}{*}{$\begin{array}{l}\text { Type } 316 \text { Stalnieas Steel } \\
\text { V-15Cr-5T1 Alloy } \\
\text { T14381 Alloy }\end{array}$} & & 9.10 & 10.3 & 7.08 & 0.24 \\
\hline & & $\operatorname{lit}_{t \hbar}^{8,76}$ & 10.3 & 7.43 & 0.26 \\
\hline
\end{tabular}

Inhalation (BRP ${ }_{\text {at) }}$ ) associated with the blanket/ ohield designs bafed on use of stainless steel structural material. One finds that beyond $30 \mathrm{yr}$, after reactor shutdown, the BHPatr in the cat $D$ Dysteas, which have softer neutron spectra than the D-T syatem, exceed that of D-T. Th1s 1a due to the fact that many of long-tern radioactive isotopes, ${ }^{6}{ }^{\mathrm{N} 1}$ for Instance in this case, ara Induced to an appreclable degree through $(n, y)$ reactlons which are favored by low-energy neutrone. The results preeented in P1g. 3 indicate how one has to reduce the $\left.d\left(d_{3}{ }^{3} \mathrm{He}\right) \mathrm{n}[2.45 \mathrm{MaV}]\right)$ from the fuel cycles involving dauterium, in order to fully explote "clean" advanced fuel reactor designs.

\section{Iuel Crale Conideration:}

Tuel cycle ecenarios have been developed for Cat $-D-D$ and $D-{ }^{3} H$ e fustion reactors. A schemintic of the fuel proceasing cycle for catelyzad-DD is illustrated in F18. 4. Whather the reactor has a divertor or bot, the exhruat from the pleam will oventudily be pumped by the vacuum system, moat 11kely by compound cryopumps. Upon regeneration of the vacuum pump, the fuel is then processed for chenical purification, lootopic enrichment, storage, and refueling. The chemical purification subsystem is dealgned to ramove all condenatble tmpur1ties ( $C D_{X}, D_{2} \mathrm{O}, \mathrm{N}_{2}$, etc.). The hellum is then separated from the $D_{2}$ fuel by a falling f1lw condenser. The possibllity extsts that the hellum, which is pumped separately, may be recovered from the vacuum aystem such that it is suff1clently free of tritium that it en be proceseded directly. The hellum is then 1sotoplcally epriched and ${ }^{3}$ He 1a a product, which is a valuable fuel for a $D-{ }^{3}$ He reactor. Isotopic separation of hellum 1uotopes appeara to be stralghtforward, using cryogenic diatiliation.2,3 Separation factors are reported higher than for cryocenic diutillation of hydrogen 1sotopes. 4 The hydrogen Ieotopea are thus 1sotoplcally distilled at $v 20 \mathrm{~K}$. It 1t neceasary only to remove a mall mount of the protium is $t D$ from the top of the column, at the tritiu 10 recycled an fuel. Qualitativaly, the component of the procesaing cycla are very etriler to a 


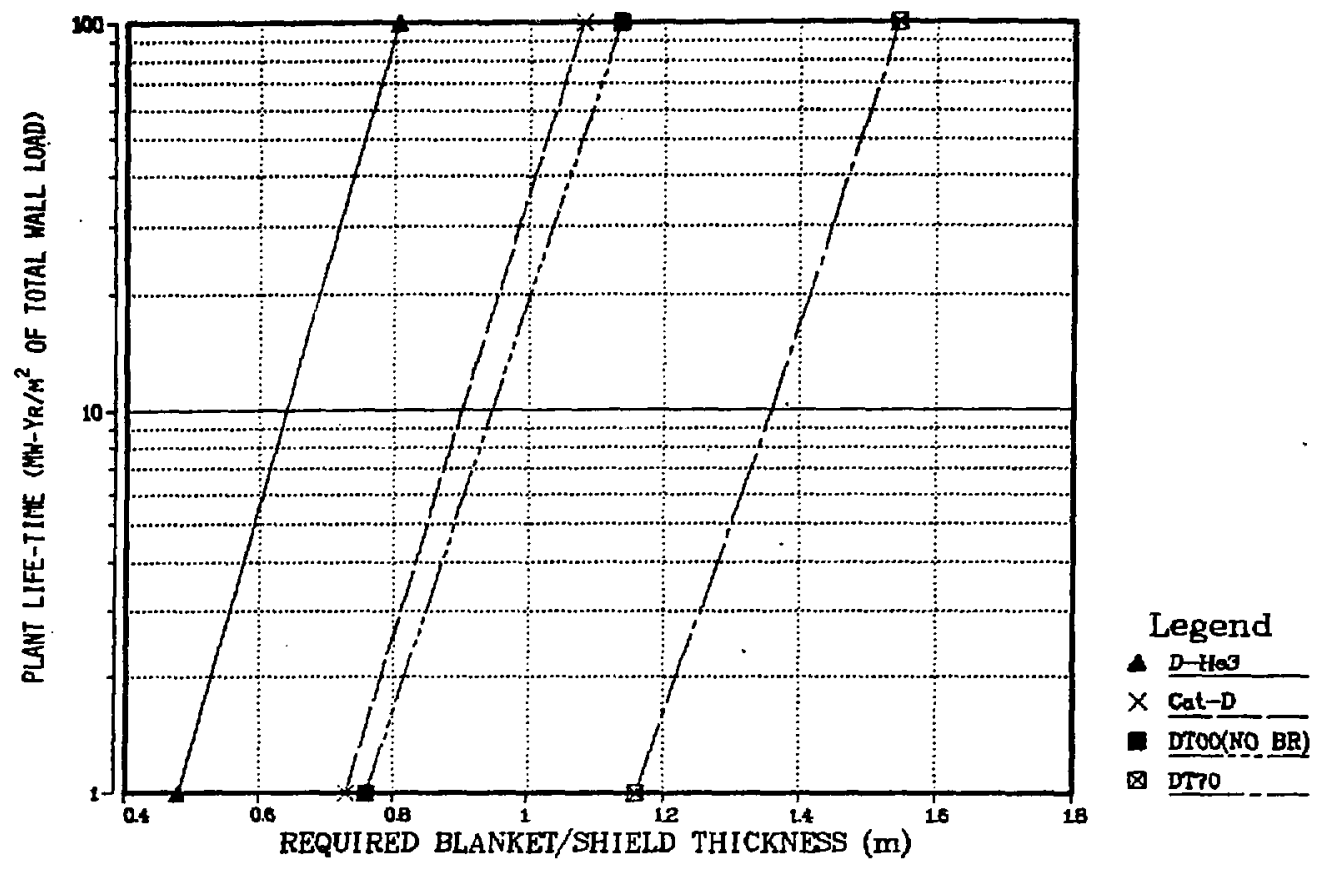

Fig. 2. Blanket/ohield thickness for fusion fuels.

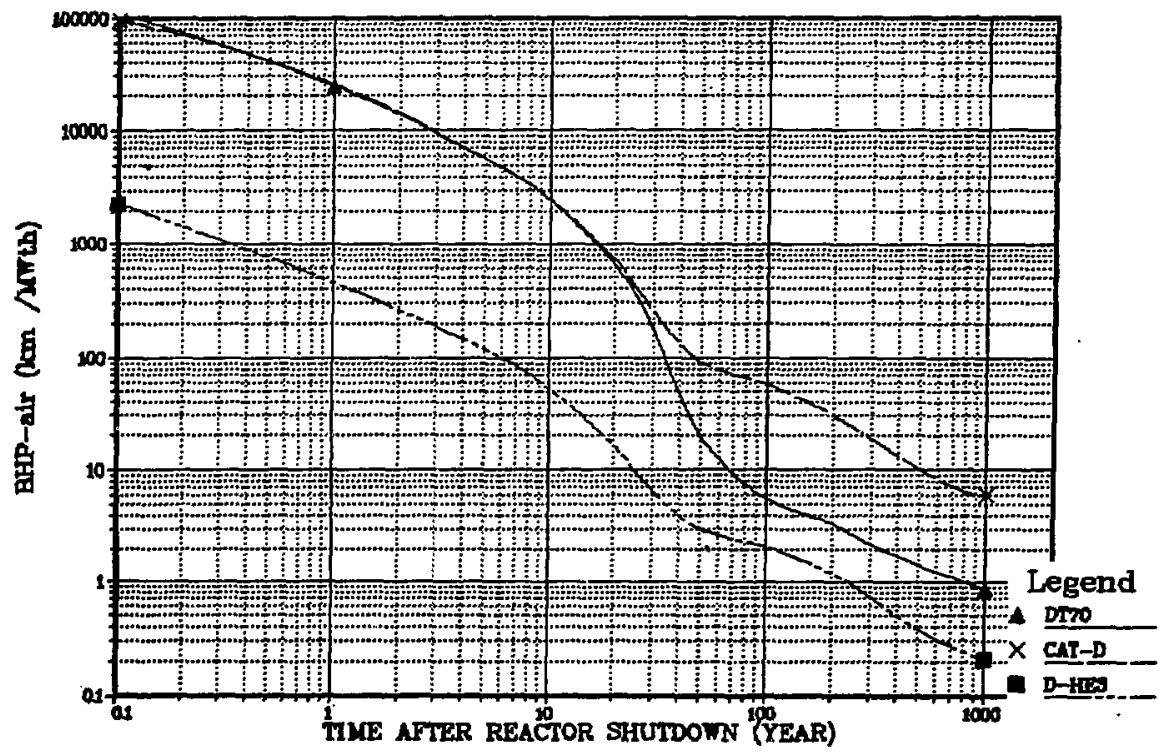

F18. 3. Blologfenl hazard potential in air for fusion fuala for stalnlese stael structure. 


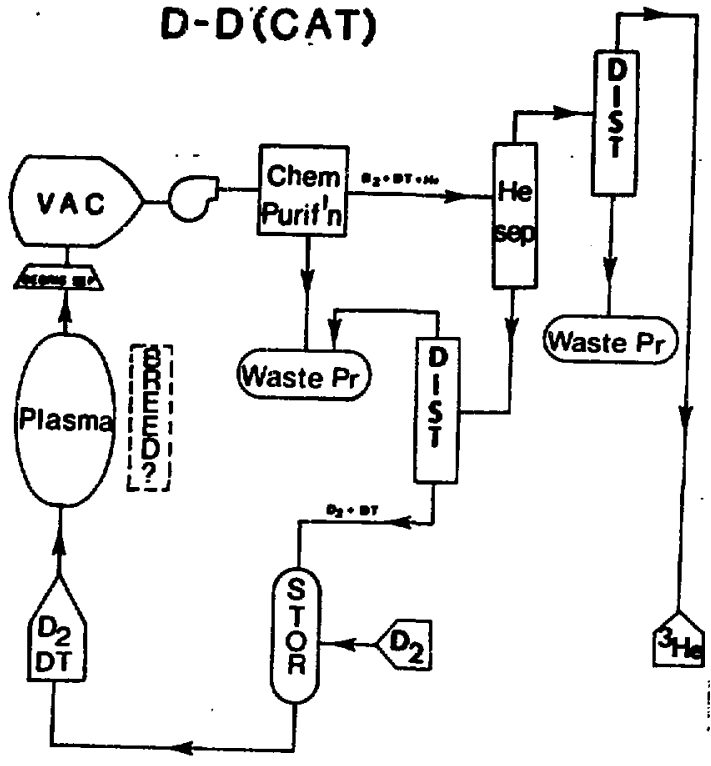

F18. 4. Fuel cycle schematic for cat D-D systen.

D-T fuel processing cycle $e^{5}$ with the additional feature of lsotopic enrichment of heliun.

The D-3ife fuel procesaing cycle (FIB. 5) ia quite efintlar to that of the D-D cycle, except that ${ }^{3}$ He is used as a fuel and tritiuri is not racycled. The hydrogen 1sotope separation untt then muse separate $D-T$ as vell as .HD. Although deuterium is plentiful, 3He is not. Potential sources of ${ }^{3}$ the will be discussed.

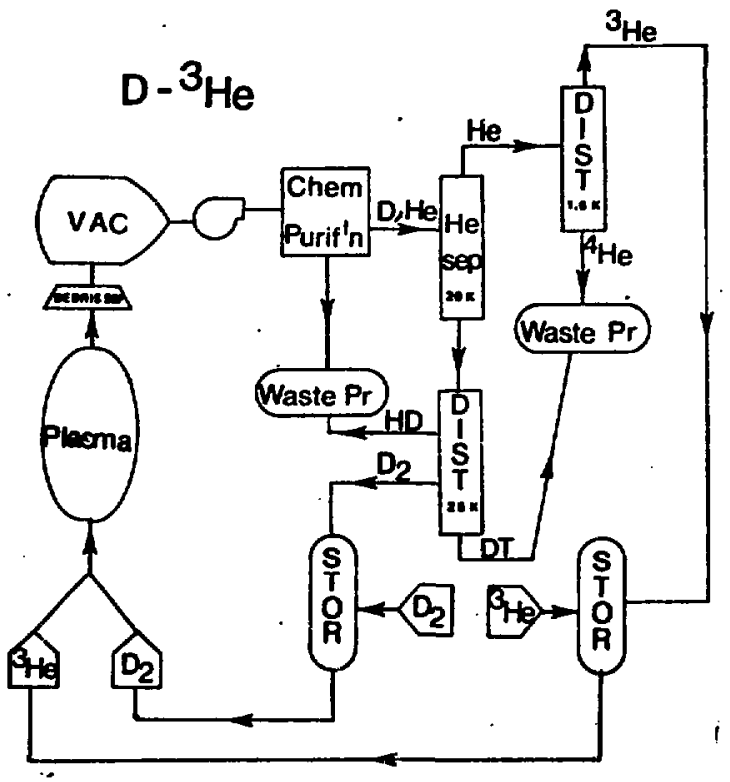

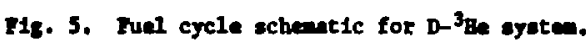

The fuel reprocesaing paranetere and cost: for $D-T$, cat-DD and D-3ile cases for a reference 2500 with reactor are ahoun in Table IV. The D-T and cat-DD casea heve comparable vacuus purping requiresentw, which is a afor enst iten in the fuel cycle system. The D-3 $\mathrm{Be}$ case hes reduced hydrogen puming requirenente but ignificantly Incrensed the purping requirements resulting in higher vacuun ayaten costs. The totil fuel cycle oystam coste are very alndine for all cases.

19 noted previously, deuteriun is abundant while ${ }^{3}$ He is not. Potentially avallable U.S. resources of ${ }^{3} \mathrm{He}$ are entimated to be $200-500 \mathrm{~kg} .{ }^{6}$ A 2500 wth D-3he reactor would burn $330 \mathrm{~g} / \mathrm{day}$ or $120 \mathrm{~kg} / \mathrm{gr}$. Since natural resources of ${ }^{3}$ He are not sufficlent, the fuel must be supplied elther from a D-D reactor or from decay of tritium.

A 2560 wth renctor burning no ${ }^{3} \mathrm{He}$ w11 produce 244 of of ${ }^{3}$ ie per day. This is not suffictent to supply one comparable D- ${ }^{3} \mathrm{He}$ reactor. Further, since some ${ }^{3}$ the vill be burned in the cat-DD reactor, the support ratio w111 be less than $\sim 0.5$.

Another potential source 1s tritium decsy. To produce $120 \mathrm{~kg} / \mathrm{sr}$ of ${ }^{3} \mathrm{He}$, a tritium Inventory of 2150 $\mathrm{kg}$ is required. A atorage factlity for this amount of tritium is estimated to cost 200 million dollars. Such large Inventories of tritium are clearly a major concern. The source of tritium production could be from D-T resctors. Assuming the excess tritium breeding ratio is 0.1 , 1t would require about $170 \mathrm{D}-\mathrm{T}$ reactors

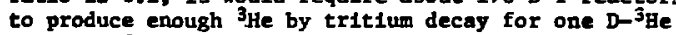
reactor of the same power level. This obviously is too low a ratio of $D-{ }^{3} \mathrm{He}$ to $\mathrm{D}-\mathrm{T}$ reactors to be of any Intereat. It $1 \mathrm{~s}$ clear that utilisation of $\mathrm{D}-{ }^{3} \mathrm{He}$ requires the use of $D-D$ reactors as a source of ${ }^{3} \mathrm{He}$, and even then one will probably require at least two $D-D$ reactors for every $D-{ }^{3}$ He reactor of the ane power level.

\section{Safety Considerations}

The presence of tritium $1 \mathrm{~s}$ one of the safety hazards under consideration. The rotal tritiun Inventory varles depending on the fuel combination involved. A typlcal 2500 wWth D-T system would reguire $8000 \mathrm{~g}$ of tritiua invertory, cat-DD $100 \mathrm{~g}$, and $\mathrm{D}-{ }^{3}$ He only $10 \mathrm{~g}$. of those totals the amount of tritfun considered to be vulnerable is $2000 \mathrm{~g}$ for $\mathrm{D}-\mathrm{T}$, about $20 \mathrm{~g}$ for cat-DD and about $2 \mathrm{~g}$ for $\mathrm{D}-{ }^{3} \mathrm{He}$. The vulnerable positions are that part of the tritium which could concelvably be released In the case of an accident. Even with Inventorles as low as a few grams, some type of emergency tritiun cleanup syste will be required.

The Induced radioactivities in the first wall and the structural materials in the blanket and shield are the other for sources of radioactivity presently being connidered. Several candidate materials have been constdered for all three fuel syotems. The candidate antertals considered are 316 stainless oteel, T1 4381 and V-15Cr-5T1 alloys. The normelized activit1es (C1/Mith) of these alloys have been calculated for prelininary alternate fuel design conditions both during reactor operation (from 1 second to 2 years) and following reactor shutdown (from time zero to 1000 yeara).

The atwopheric $(x / Q)$ diaperaion of tritiun and of atructural weterinl was exanined for a hypothetical. eccldent' beaed on a ahort-term unifore relesse from a point source. A atiple model is utilized in order to comare the relative external dose from the candidate alloye disparsed In a Gausian plume. The impact of tritlu leaking from the reactor bullding following a 
Table IV. Fusl Procmeing Requiresante for Altarnate Funton Fuel Crelee

Therend Power - 2500 ins(th).

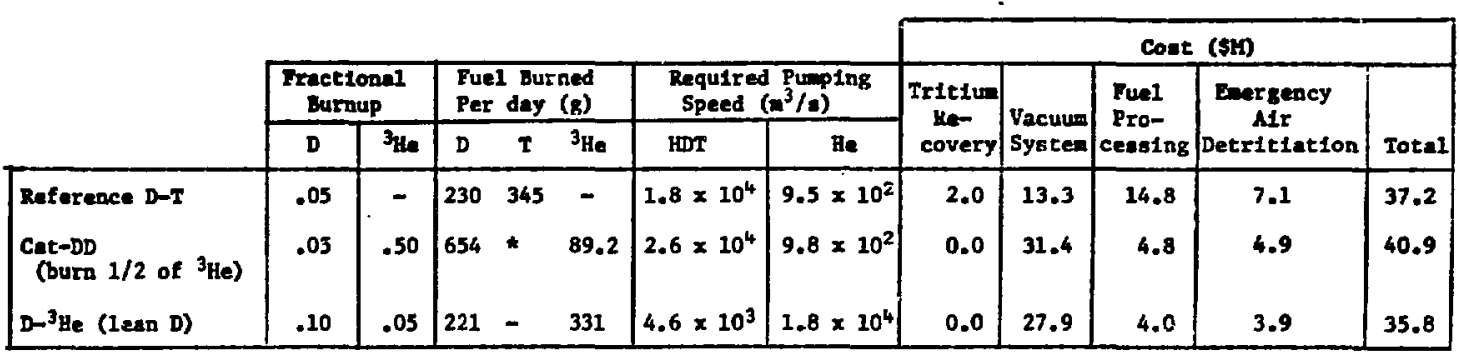

* recycled.

hypothetical accident was also caiculated using the waine wethodology.

The relative external dosea due to given structural material in different advanced fuel systems being volatized by a hypothetical reactor accident and 1 ts leakfng out of containment is shown for $3 i 6$ stainless ateel in $\mathrm{Fig}$. 6. The sarre information could have been plotted for the other candidate materials; but they are generally similar, except the values are approximateiy an order of magnitude lower for the vanadium alloy.

Based on the results, the cat-DD syotem produces higher total external doses following a hypothetical accldent than does a D-T system; while the $\mathrm{D}^{3} \mathrm{He}$ systen produces much lower doses. The relative doses for D-T compared to $D-{ }^{3} \mathrm{He}$ are about 10 times as grent for 316 SS, 35 times for the vanadium alloy and about 60 times for the titanium alloy. The impact of the absolute value of these doses relates to the size of exclusion boundary that would be required around * fuaton power plant.

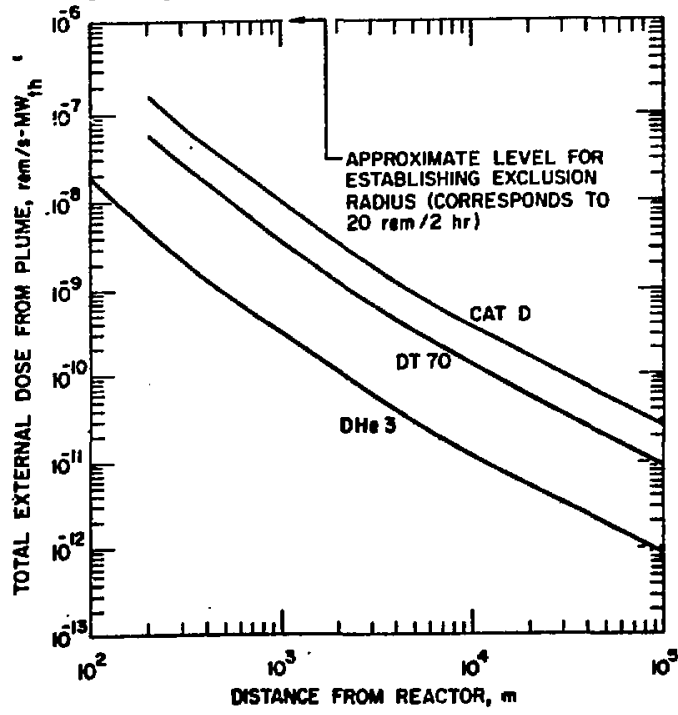

F18. 6. Relative external doses for alternate fun eyeter.
The relative effect of the vulnerable tritiun inventory in the reactor building was also calculated for each of the advanced fuels systems. The noralized activities of tritium would be $7.7 \times 10^{3}$ C1/MWth for D-T, $77 \mathrm{C1} / \mathrm{MWth}$ for cat-DD, and $7.7 \mathrm{C1f}$ whth for $\mathrm{D}-{ }^{3} \mathrm{He}$. The activity of tritiun when compared to the activity of structural material is generally quite small. The external whole body tritium doses from the plume at 200 neters from the reactor and at one hour following an accident would be $1.9 \times$ $10^{-9}$ realo-MWch for $D-T, 1.9 \times 10^{-11}$ for cat-DD, and $1.9 \times 10^{-12}$ for $D^{-3} \mathrm{He}$. The whole body doses due to tritiue compared to the doses due to structural materials are suall (on the order of 0.10 percent).

\section{Concluston:}

Based on this Initial study, the following pre11minary conclusions are developed:

1. Radintion damage parameters (atomic displacements and gas production rates) are reduced by about two orders of magnitude for $D-{ }^{3} \mathrm{He}$ compared to $\mathrm{D}-\mathrm{T}$ for the sane total wall loading. D-D offera about a factor of two reduction compared to D-T.

2. Tor cyclic fuston concepts, surface heat loading IInitations reduce the total wall loading by - facror of three for $D-D$ and a factor of five for $D-3$ He compared to D-T. (Alterate fuels are probabiv better suited to steady-state fusion concepts.)

3. Surface roughing will probably not significantly reduce reflection of cyclotron radiation; there 1. very little experimental data.

4. The use of low-Z, non-conducting surfaces (e.8., oxide coatings) way not be acceptable, thus, perhaps, aking Imurity control wore difficult for alternate fuels.

5. Shlelding requiremente (e.g. . thlcknesses) are reduced by about a factor of two for $\mathrm{D}-{ }^{3}$ He compared to $D-T$. There is little advantage for $D-D$ compared to D-T for the save total vall loading.

6. Heintenance for any deuteriun-based fuel cycle will probably have to be by remote metbode.

7. Lons-tern DKP for activated anterial for D-D 18 eidilar to D-T. After about 100 years, the diffarence betwen $D{ }^{3} \mathrm{He}$ and $\mathrm{D}-\mathrm{T}$ is onll for atalnlese steel atructural meterials. 
8. The tritiva throughput for D-D is about a factor of 15 less than for D-T for the sase total pover. For cat-DD, the reduction 1s 100 over D-T. For D-JHe, the reduction 18 about 1000.

9. There is 11ttle difference in the total cont of the fuel handisng/vacuua aysten between $D-T$, D-D and D-3He.

10. The only leastble source of ${ }^{3}$ He secms to be - D-D reactor; support ratios of D-3He to D-D y111 be at least $1: 2$.

11. D- ${ }^{3}$ he reactors will result in lower doses (10-100X lower) under posstble reactor accident cond1tlons compared to $D-T$, but $D-D$ rcactors may produce hsgher total external doses coapared to D-T.

\section{References}

1. L. 1. Iurner and $M . A$, Abdou, "Computational Kodel for Superconduct1ng Toroldal Field Magnets for a Tokmak Reactor," Seventh Sumposiun on Engineering Probleas of Eusion Rescarcin, (Knoxville, 1977) pp. 762-766.

2. W. R. HIlkes, "DIst1llation of He Isotopes," Proc. of ICEC-4, Eindhoven, 1972, IPC Science and TechDolosy Press (1972), pp. 119-12.

3. W. R. Hilkes, ${ }^{3}$ He- ${ }^{4}$ He Distillation Apparatus, Hound Labozatory report, IILN-2005 (March 21, 1973) Pp. 15.

4. W. R. Uilkes, Hound Laboratory, private comantcetion.

5. J. L. Anderson and R. H. Shuman, "Trit Lun Systems Test Assenbly, Design for llajor Device Fabrication leview," Loc Alanos Scientifle Laboratory Report IA-5855-P, (June, 1977).

6. T. B. Thinehawser anci $i . J$. Wittenbers, Man Evaluation of Fuel Resourees and Requirements for the Slagnetic Fuston zucrey Propram," Mound Laboratory ieport kIlis-2419 (October 31, 1978). 
SHIELDING AND MAINATNABILITY IN AN EXPERTMENTAL TOKAMAK

\author{
M. A. Abdou* \\ Argonne National Laboratory \\ Argonne, Illinols 60439 \\ G. Puller \\ McDonnell Douglas Astronautics Company \\ St. Loufs, Mtsoour1 63166 \\ E. R. Hager \\ General aromic Company \\ San Diego, Callfornia 92238 \\ W. F. Vogeleang \\ Universicy of Wiscoasin \\ Madison, Wisconsin 53706
}

\section{Introduction}

It has long been recognized by the furion community that provisions must be made for remote maintenance for all tokanak reactor components inside the toroldal afield (TF) colls (e.g. flrst vall, blanker, bulk shield, etc.). This does not 1mply, however, that all maintenancerelated operations have to be carried out by remote means. For example, there is much equipment located in the reactor building outside the TF coils that has to be maintained. Furthermore, there are many operat tons such as planing, viewing, connects/disconnects, and adjustment of mintenance equipment positions that can be made inside the reactor containment bullding exterior to the TF colls.

Therefore, a critical issue that has to be resolved In developing a complete alntenance plan for the next generation of experimental tokamak reactors such as ETP and INTOR is whether there is a net betefit from designIng the reactor for human access into the reactor floor within a short time (a few hours to one day) after shutdown so that some maintenance operatious can be carried out in contact and/or seaf-renote mode. From maintenance plan standpoint, the benefit from personnel access is primarily a reduction in tha total dowatime and hence an improvement in the resctor avallability. The principal penalty is an increment in the capital cost for the additional shield that is required above and beyond that necessary for radiation protection of the reactor components.

This paper presents the results of an attempt to develop an understanding of the various factors involved. This work was performed as a part of the task assigned to one of the expert groups on the International Toknak Resctor (INTOR). However, the result: of this investigation are belleved to be generally applicable to the broad claes of the next generation of experisental tokamak facilities such as ETF.

The ahielding penaltios for raquiring peraonnel accese are quantified in Sec. 2 . This ta followed by a quentitative estinnte of the benefits aseociated with personnel access in Sec. 3. Section 4 colpares the penalties to the benefite and develops concluslone and recomendations on resolving the issue.

\section{Panalties of Personnel Accens}

In the abnence of penetrations, e properly deeigaed mapet (buik) anleld is capable of raducing the blolog1cal dose in the reactor hall to 21 mren/hr within $24 \mathrm{hr}$ after shutdorn. This dose level peralts a person to work cont1nuousty $(40 \mathrm{hr} / \mathrm{wk})$ without exceeding the ICRP

\footnotetext{
"Author'a work perforned during stay at Georgie Inutitute of Technolosy and eupported by the Georgla Pown Company.
}

guides for occupational exposure. The premence of anor penetrations such as those for neutral beass, divertors, and vacuum pumping results, however, in substantial radiation streaning into the reactor building. ${ }^{2}$ This will result in strong activation of the equipment located at the outer end of the penetration $(e . g$. beam Injector components and walls), reactor bullding liner, reactor support frame, overhead cranes, pololdaI coll, located outside the bores of the TF coila, and all equipment located in the reactor bullding. For the preliminary INTOR design concept in the prasence of $0.8-$ dlameter beam ducts, detafled calculations resulted in the following estimates of the biological dose in the reactor bullding.

\begin{tabular}{cr} 
Tine After Shutdown & $\begin{array}{c}\text { Dose (aren/hr) } \\
\text { the Injector }\end{array}$ \\
\cline { 2 - 3 } 0 & $6 \times 10^{6}$ \\
$12 \mathrm{hr}$ & $4 \times 10^{4}$ \\
$1 \mathrm{day}$ & $2 \times 10^{4}$ \\
$1 \mathrm{wk}$ & $1 \times 10^{4}$ \\
$1 \mathrm{mo}$ & $1 \times 10^{4}$ \\
$6 \mathrm{mo}$ & $3 \times 10^{3}$
\end{tabular}

Such a blological dose is too high to perait personnel access for any reagonable pertod of tire.

For personnel access to be fearible, additional shielding must be provided to prevent radiation etremIng into components located in the reactor building. Our objective here is to meke an approxinate entinnte of the cost of this addit tomel shield. To do this one nust define an acceptable blological dose end a method of shlelding.

The ICRP rules linit the aximan Individunl occupetionel exposure to $1.25 \mathrm{ren} /$ quarter. This translutes into a dose 1Int of $2.5 \mathrm{mrea} / \mathrm{hr}$ to a person working the entire quarter on $40 \mathrm{hr} / \mathrm{wk}$ basis. Another quant-legal principle is to reduce the dose as low at reatonably achievable (ArRA). A massure of anvironientel inpect that is presently receiving ach attention is the total cumlacive dose to the entire work force. Prudent precticas require kaepling the total cunulative dose (personIeno) as low at posesble. Our evaluntion suggeats that for the purpose of ealning humen eccens the dealen target should be to reduce the biological dose in the reactor bullding to $\leq 1$ area/hr within $24 \mathrm{hr}$ after shutdown.

One thaoreticel method of reducing the blological dose In tha resctor bullding io to eploy materisls (for constructing all components out 1 de the bulk shield) that do not traneme under neutron Irradiation to redioIeotopes with half-11ven longer than a fow anuted or hours. In practice, there in no suitable material to eerve this purpose.

Madiation shielding in the only effective caen of 
lintifns the blological does rate in the resctor building. There are two methods of shielding acainat radiation treasing from penetrations. The first is to eploy a ahield plug that conplately cloes each penetration at all times the neutron production is not zero. The principal difficulty here 10 that the functional requiremate of pone panerations require that these penetrations be open during part of or all of the plasm startup and burn timen. For exmpla, atutral bean Injection during the startup in accompanied with a subatantial neutron yleld fros the hented plasw. Furthermore, if INTOR has to be driven, bean 1njection will also be neceseary during the peak power portion of the plesme burn. It 1s not clear at preaent whather vacuti pumping (for the plassa chamber) during the plesm burn will be necessary. Holee for divartors, if a divertor is usad, will of course have to remain open during the plasen buxn.

The only ahielding option whose viability is not subject to uncertainty is a local exterior shield that surrounds all penetrations and functionel end equipaent (1.e. equipent located at the outer end of the penetration such as a vacuum pump, bean injector, or a detector). This ahield is always reaulred for radiation protection of reuctor components, but the magnitude of radiation attenuation it has to provide is larger if personnel accese Into the reactor bullding after shutdown is to be permitted. Kultidinensional cransport calculatiors and nuclear analysis effort carried out for INTOR chow that the largest and most costly requirement for personnel accesa is the additional shield around the functional end equipmant. The largest portion of this shield is that required for the iean infectors because of their large alze and the correspondingly large exterior surface area that has to be covered. A reactor syatem in which the opening of the nautral bean duct at the first wall is 0.8 m in diameter was analyzed. The bean duct was assuned to have anifora crosa section and connected to the beas injector at a location that is 3 a away from the firet wall. The ala of the bean infector was taken to be 10 a long, 6 m wide, and $6 \mathrm{~m}$ high. Based on previous atudies for experimental power reactors, this system is roughly within the range of what can be expected for INTOR. For this syoten, it was found thet $250-\mathrm{cm}$ thick shield providing radietion attenuation and induced activation characteristics similar to that of a nixture of tafinless steel and boron carbide plus lead need to surround the exterfor arfaces of the bean injectors in order to reduce the blologicel dose rate in the reactor building below 1 mren/hr within 24 hr after shutdown. This biologicel doee rate variea with time after shutdow as follows (for a neutron wall load of $1.6 \mathrm{mw} / \mathrm{m}^{2}$ ):

\begin{tabular}{cc} 
T1m After Shutdown & \multicolumn{1}{c}{ Dose (nrea/hr) } \\
\cline { 1 - 2 } 0 & 350 \\
12 hr & 14 \\
1 day & 0.8 \\
1 wh & 0.3 \\
1 wo & 0.25 \\
6 mo & 0.09
\end{tabular}

These calculations were wade for an operating period of $3 \mathrm{~m}$, but it hould be noticed that the level of radioactivity roachea $250 z$ of the maximin after only a few days of oparation.

An irportant conclueion obteined in the course of this ascasenat it that the une of the so-called "lowectivation" wateriais such as eluninue are not ueful for shielding componente in the reactor bulldins for ecveral ressons: (1) the activity of ${ }^{24} \mathrm{ka}$ produced in aluainu (helf-11fe w15 hr) requires enverel daye of decey to reach an ineignificant lovel; (2) aluninu is a poor neutron attenuator; therefore, for the snow thickaose of material a higher neutron leakage will obtain, leading to higher activation of bull.ding liner, structural torque fram, etc.; and (3) aluninu is a poor attenuator for gawe raya; therefore, wo decay gaman fron deeper reglons of the shield will reach 1ta surface and eacape into the reactor bullding.

Penetrations with cross-section area saller than those of the neutral beam will require less ahield (andler thickness) around their functional end equipwent. The ducts for vacuum punping (plasms chamber evacuation) will have roughly the sane crosa-section arca as the ducts for neutral beame except that the ability to bend the vacuun pumping ducts significanty reduces radiation streaming.

Table I shows a sunary of the cost of ahield required around the functional end equipuent of the vartous types of peentrations. Approxinstely $80 \mathrm{z}$ of this cost is attributed to the requirenent of peraonnel access. These cost estimates are based on a unit cost of $\$ 70,000 / \mathrm{m}^{3}$ of the shield ( $212 \$ / \mathrm{kg}$ for physicaj density of $5800 \mathrm{~kg} / \mathrm{m}^{3}$ ). This cost includes material, fabrication, and cooling expenses. Other relevant assumptions are indicated in the table.

The largest cost Item is that of the shield around the beal infectors because of the large surface area around each injector. The shield for the vacuun punpa is Included in Table $I$ and $1 t$ is assuned that no divertor is incorporated. The cotal cast of the additional shield strictly required for permitting peraonnel accene 1s $289 \mathrm{MS}$. This is the cost penalty of personnel accers.

It must be noticed that this shield cost penalty is very sensitive to certain technology choices as ladicated in Table II. For example, if a divertor 1a incorporated the divertor shield increment attributed to personnel accens is estimated to be $238 \mathrm{kS}$. The use of if henting Instend of neutral beam reduces the cost of abielding a1gnificantly for several ressons: (1) the feasib1lity of aaking bends in rf ducts; (2) larger power denalty per unit area at the first wall makes if ducta smaller than those for neutral beam; and (3) the flexibility in geometrically locating the if generator. Notice that the use of aegative Ion deuteriue sourcee (al1 calculat lon: above are based on $D^{+}$) will al a0 reault in a Ignificant reduction in the cont of the ahield. If $x f$ heating 1. used and no divertor le eployed the total cost penalty of shield for personnel eccene 1. only $48 \mathrm{MS}$ compared to $120 \mathrm{MS}$ for the neutral beas/divertor caee.

\section{Incentives for Personnel Accese}

In Sec. 2 the penalties of the additional abielding to permit perwonnel access were eranined. In tht eection the benefite that can be obtafned from enabling malntanence personnel to enter the reactor butlding withIn 24 hr after shutdown are anseased. The two general matenance scenartion connidered here $3 r e:$ all-remote and contact/partiel-renote. The entatenance ecenurlo hes been developed in enough detell to provide eetinated fallure frequency and aelatenance plan date for anjor reactor componente.

The arean of the reactor bullding that have been considered for contact or partial-reote (thil can alvo be defcribad as contact assiated rewote) anintenance loclude all acceneible componente or syatem that are external to the resctor ain (bulk) obield. Thie generally includes inetrumentetion and control diagmontics, coolins oyutens, power leads, and the tritter recowery cyate a well is a portion of the alntemance oparatione on eany componenta Inside the shield. Both the ell-renote and the contact/partiel-remote entatenance 
TABLE I. Cost of Shteld for Personnel Access

\begin{tabular}{|c|c|c|c|}
\hline $\begin{array}{l}\text { Component with } \\
\text { Penetration }\end{array}$ & $\begin{array}{l}\text { Cost of Shteld Around } \\
\text { Ead Equipmont } \\
\text { (Based on } 70 \mathrm{ks} / \mathrm{m}^{3} \text { ) }\end{array}$ & $\begin{array}{l}\text { Cost of Portion } \\
\text { of Shield for } \\
\text { Personnel Access }\end{array}$ & Rewarks \\
\hline Neutral beams & Bo MS & $65 \mathrm{MS}$ & 7 infectors (each is $10 \times 6 \times 6 \mathrm{~m}^{3}$ ) \\
\hline Diagnostic & $12 \mathrm{MS}$ & a & 50 detectors (each 1 \& $1 \times 1 \times 1 \mathrm{a}^{3}$ ) \\
\hline Vacuua pump: & 21 MS & $16 \mathrm{MS}$ & 30 vacuun ducts (2 punps per duct) \\
\hline Other: & $10 \mathrm{MS}$ & $\mathrm{AMS}$ & \\
\hline TOTAL & $223 \mathrm{HS}$ & $89 \mathrm{MS}$ & \\
\hline
\end{tabular}

a The shield around the Instrumentation and control "end equipwent" appears to be always required for radiation protection of this equipment from background radiation.

TABLE II. Effect of Technology Cholces on cost of Shield for Personnel Access

\begin{tabular}{|c|c|}
\hline Option & $\begin{array}{l}\text { Total Cost of Shield } \\
\text { for Personnel Access }\end{array}$ \\
\hline Neutral beams, divertor & ${ }^{a}$ \\
Neutral beams, no divertor & $120 \mathrm{MS}$ \\
rf (or $\mathrm{D}^{-}$), no divertor & $89 \mathrm{MS}$ \\
\hline
\end{tabular}

The cost of the shield for the divertor can be much larger than what is assumed here, depending on the particular divertor concept considered.

extermal to the reactor maln (bulk) shleld. Th1s generally includes lastrumentation and control diagnostics, cooling systems, power leads, and the tritium recovery systen we well is portion of the mlantenance operations on wany conponents inside the shield. Both the all-remote and the contact/partial-remote maintenance schemes are strongly design-sensitive and will require continuing attention during the machine conceptual deaign phase for proper implementation.

\subsection{Contact and Partial-Remote Maintenance}

The three major minterance operation methods are contact, all-remote, and partial-remote. A wide range of partial-remote operations can exist between the contact and all-renote extremen and this is the area in which many of the INTOR maintenance operations way fall if adequate shielding is provided.

Contact mintenance is defined as the une of direct hande-on or convent lonal techniques including hand-held and guided tools to repalr or antesta componenta or

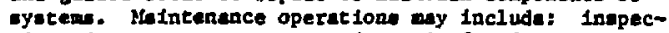
t1on, damage asersanent, and repalr for forced outages avell as echeduled operation in connection with prevent fve mintenence.

All-remote antenance operatlons are those wh1ch mut be accompliahed whthout the benefit of any humen assistance within the 1mediate erea of oparation. The actual talks are performed by minipulators (some with force feedback) or by spectel tools and fixtures which any be guided or aseloted by mapulators or crepas. These operattons generally require 8 to 500 times Ionger to perform the aan takk than wh contact work, Table III, taken fros a recent renota gyoces sentuar, compares the tim to perform varlous remote tapke with contact work.

In the case where sose perbonnel eccass is evafleble fa.s., during the pertod when all whelding in in
TABLE III. Comparison of Time Required to Perfarm Typical Taske

\begin{tabular}{|c|c|c|c|c|c|}
\hline & LASL $^{a}$ & $\mathrm{MIT}^{\mathrm{b}}$ & $\operatorname{MASA}^{C}$ & $M B A^{d}$ & $\operatorname{CEA}^{e}$ \\
\hline $\begin{array}{l}\text { Two-armed man } \\
\text { Unsulted } \\
\text { Sulted }\end{array}$ & 1 & 1 & 1 & $\begin{array}{l}1 \\
8\end{array}$ & $\begin{array}{l}1 \\
-\end{array}$ \\
\hline $\begin{array}{l}\text { Mechanical k/s } \\
\text { Two-arm } \\
\text { One-arm }\end{array}$ & $\begin{array}{r}8 \\
16\end{array}$ & $8-10$ & 8 & $\begin{array}{l}2 \\
-\end{array}$ & $\begin{array}{c}2-8^{\mathrm{F}} \\
-\end{array}$ \\
\hline $\begin{array}{l}\text { One-arm EM } \\
\text { Position control }{ }^{8} \\
\text { switch control8 }\end{array}$ & $\begin{array}{r}80 ! \\
480\end{array}$ & $\begin{array}{l}40-50 \\
80-100\end{array}$ & $\begin{array}{r}64 \\
640\end{array}$ & $\begin{array}{l}55 \\
-\end{array}$ & $\begin{array}{l}10-30 \\
50-100\end{array}$ \\
\hline $\begin{array}{l}\text { Crane - } \\
\text { Impact wrench }\end{array}$ & $>500^{\circ}$ & $>100$ & $>600$ & $>500$ & $>100$ \\
\hline
\end{tabular}

ased on installing bolt and lifting aling.

based on eight definitive taske.

$c_{\text {Based on analyats and literature survey. }}$

dased on typical valve changeout.

Based on variety of extensive teske uaing different anipulators.

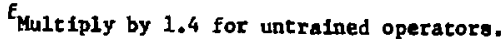

8 No force feedback.

place, but preparatione are in progress for unshielded remote work) partial-rewote anintenance may be carrled in order to mininize the tfime loat with all-renote operat1ons. Varying wounts of contect waintentace operatrops can be perforwed on different components depending on the design of the equipment and the tank involved. Those operations sometias called "ued-renote" (Including long-handiad tools and temporery or shadow ah1elds) are included in the partial-ramote category for purposes of this anelyais.

\subsection{Ut1liestion of PartLa1-Reote Mintenance on IMTOR}

Operatione at fiasion reactors provide many exarplas of partial-rumate mintenance. The une of longhandied tools in vater-shlelded poole allow significant saving in time ane opticel equipment. Teaporary or shadow ohielda and speciel tools ara frequently utilized for aintenance taske such as chinging filters.

An exaple of a partial-recote mintenance calk on - Eulion reactor with edequate blologicel ahielding to provide pareonal accene soon (ang 24 hr) after shutdors 1a an follows: in fon source on a neutral bean injector hat falled. The neutral bean ascably 10 shialded but the 10n aource 10 exparately shielded and detachable 
aloos with its shield. Electrical and cooling services are supplied through the ahleld and have convent lonal externel dieconnecte. As coon as ellowable after shutdown, esintenance personnel enter the renctor bullding and dieconnect the electricel and cooling upplies os wil st the 1on source shleld structural fasteners. rooling and fixturea ere ast up locully for the actual cource renoval operation. The percounel teaporarlly nove to anfe dietance or behind a abdow shield while the resote or seni-raste equipment rewoves the source and shield aseembly and retomerte a aw source and shield asembly. A telporary ohielding cover is pleced over any exposed radloact 1 ve portlons of the rewoved Ion source and thleld ansembly. After inlelding is in place, aintanance pereonnel can reapproach the aeutral bear and complete the Ion source hookup. Alternatively, the entire change-out could ba accompliahed by personael utilizing shedow shielding and long-handled tools and/or cranes. About $25 \%$ of the or 1 ginal renote work resalns.

Significant avinge in time, couplexity of reactor components, disconnects, and renote equipenent can be reallzed when compered to an all-resote operation.

Many other opportunities exist for more efficient operations by use of partial remote operations on shlelded reactor componenta such as cryopumps, control and 1nstrumentation diagnosics, divertors, etc.

\subsection{Ut1lization of Contact Maintenance on INTOR}

Obviously, the greatest maintenance time savings occur when an all-remote operation can be replaced by a contact maintenance operation. If areas exter1or to the reactor shield can be made avallable by peraonnel access about $24 \mathrm{hr}$ after reactor shutdown, a number of very difficult remote operations are eliminated.

Control and instrumentation diagnoatic components extermal to the shield represent a clese of mintenance tasks which can be rather trivial under a contact anintenance acenario but which will create challemging dealgn and operationel problem if remote maipulationa are required. Replacenent or repalr of degraded optics and vacuun 1solation valves are typlcal taake. D1agnost ic modification and realignent are tasks which generally require excellent viewing capabilities and an extremely delicate touch. Exasples are laser opt 1c: and photo-diode replacementm. Conmiderable equipment and time eavinge are posaible if these meintenance jobs are contact. Many reactor control or 1natrunentation componenta require shlelding for self-protection greatly complicating the Inspection, repalr, and replacenent tasks with all-remote operations.

Breakdown of rewte anintenance equipant can wileo create serfous operational problam and add to reactor downtie. Thase breakdowns will unually occur during renote operations and therefore require special recovery equipant and deelizn provieton. Esch remote operation met be exanined to Identify equipent fallure modes. Generally, a shlelded area wust be provided to which falled remote equipmat can be woved for handa-on aeintenance. Falling this, additional rewote equipment wast be provided. Reducing the number of rewote operatione required obviously will reduce these teske.

\subsection{Inspect10n, Dangre Areagenent, and Rapalx}

An 1mportant lesue, which is difficult to quentify, related to the anount of tine required to identify reactor equipent problese. Clonely releted in the inapaction of componente to heed off fallure. When these tenke mut be accomplished rawotely, they will be torced to rely on remote viewing devicen and conelderably augented inotzuneatation.

One source ${ }^{3}$ atates that locelizetion and 1aolation functiona related to corrective matntenence of electroale equipient genrally account for $60 \%$ of the total expended mintenance time. The proportion of downtime required to troubleahoot achanical equipant is also. relatively large percantege of the total repair time.

Accomplisbing the above tanks resotely will add igaificantly to the time involved. Talevision vieving 1s raquired in wost cases since resctor equipment will be located in obscured positions and ot relatively large distances from any shielding viewing windowe that could be provided in the reactor building. TV syateme should certainly provide depth perception in order to compenexre the lack of all other human seness in a zenote environment. With only remote viewing and Instrumentation as an alde to fault identification and troublewhooting, conalderable additional maintenance tive should be expected.

Rewote repalr operations can actually create add1tional alntenance work due to unexpected incidents such as twist-off of bolts, cross-thrending of fanteners, and the dropping of dellerte parts. Many remote handing design techniques exist to help offset these problems, but the design solutions are often costly.

\subsection{Impact of Ulee of Contact/Partial-Remote Mnintenance}

In order to quantify some of the expected benefits of ut1l1zing contact/partial-remote matntenance where posstble on the proposed INTOR reactor, an analysis of the data for an all-remote anintenance acenario developed earlier for IsTOR was underteken. Conponent downtimes, manower entimates, and pareonnel exposure tiwes were exinined in as wuch depth as posstble at th1. early stage of the concept.

Mafatenance plan data are categorlzed into scheduled and unacheduled maintenance periode dapending on expected fallure frequency, 1mportance of the equipaent to cont Inued reactor operation, and redundancy provided. A preventive atntenance scenario of scheduled quarterly 28-day downtinen and schaduled 2-day weekly downtime (for 32 wk) is then pursued.

The criticel path quavterly antenance itene are shown in Table IV. All-remote downtima are cospared with contact/partial-ramote downtime expacted. Contact/pertial-remote times are calculated fron allresote tiwe entinutes uning divieors derived from remote handling experience, Including cica ahow in Tible III. The diviaors chosen Include conelderable conservatisa to ensure that time avvinga are not overeutinated. The beaic factor chosen 1o that a 5 to 1 reduction exdate betwen an all-remote job and an allcontect one.

The blanket recoating operation all-rewote dowatine, eatinated as 18 daye, in dividad by 1.43 to reflect the fact that only a portion of thia operation can be dona in the contact ode. This 1mplies that 238\% of the rasote work can be repleced by contact work. The downtin for the new contact/partial-rewote operation 1s therefore 12,6 days and the t1we soved 1s obviously 5.4 daya. of the 12.6 daya now requirad for thil tark, 1.35 deya (117) are accolpliabed by contact work. Thun, a najor portion of the downtim on thil job is atili acconplished in the remote ude. Theae proportione were chosen from a prelialnary analyala of the operations for this natenuce tesk.

A atntler approach is used for the aecond critical path iten thom, replacing limiter platee. A portion of these tirat two taks ehown in rable IV is asaived to be accomplished in parallel and the entire expariment exchenge task 1s assured to be completed wile the 
TABLE IV. IMTOR Quarter 1 y Preventative Keintence Downtion (Critical Path)

\begin{tabular}{|c|c|c|c|}
\hline \multirow{3}{*}{$\begin{array}{l}\text { Blinket - withdram } \\
\text { four eectora and recoat } \\
\text { wella }\end{array}$} & \multicolumn{2}{|c|}{ Al1 Renote } & \multirow{2}{*}{ 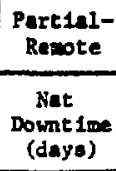 } \\
\hline & $\begin{array}{c}\text { Totel } \\
\text { Dowatime } \\
\text { (days) }\end{array}$ & $\begin{array}{c}\text { Net } \\
\text { Dowat1on } \\
\text { (days) }\end{array}$ & \\
\hline & 18 & 18 & 12.6 \\
\hline $\begin{array}{l}\text { Linters - replece } 8 \\
\text { plates from } 2 \text { sectors }\end{array}$ & 8 & 6 & 3.6 \\
\hline $\begin{array}{l}\text { Exper1mat exchnge - } \\
\text { replece } 3 \text { flrot-wall/ } \\
\text { blanket modules }\end{array}$ & 8 & 0 & 0 \\
\hline $\begin{array}{l}\text { Meintenance equiphent } \\
\text { downtioe (average) }\end{array}$ & & 0.4 & 0.1 \\
\hline 1 atartup & & 1.0 & 1.6 \\
\hline TOTALS & & 25.4 & 17.9 \\
\hline Querterly downtine aneur & & 28,0 & 18.0 \\
\hline
\end{tabular}

other taaks were in progress. A total of 19 other quarterly or annually cheduled maintenence iteme are ideatified, but all are of shorter duration than crit1cal path iteme and can be performed in parallel. Thus, the net downtimen shown are used to calculate contact parcial-rewote tines for these pacing 1tems. Plnally, additional dointime is allowed for waintenance equipment fallures and shutdown and startup of the resctor. A total quarterly downtime of 28 daye for the all-remote mode and 18 daya for the contect/partial-remote method 1. asuumed frov these eatimntes.

The wekkly mantenance plan lacludes two itema: neutral beam lon sources and divertor bowbarduent plates. Both aystem cen be serviced in parallel durIng the one-day downtime avallable under the all-remote maintenence plan. With the contect/partial-remote mode, these weekly 1tems are conpleted in $9.6 \mathrm{hr}$ using a divieor of 2.5. As diccussed in the example previously given, $325 \%$ of the original rewote work remains. The totel weekly downtime $1348 \mathrm{hr}$ for elther malntenance mode.

Since no downtine reduction is predicted for wekly acheduled alinteance under the contect/partial-ramote scheas, the avinge per quarter is 10 days for a total of 40 deya per year.

In a Imilar manner, the eatiantes of manpower for the all-resote maintemance plan were used to celculate anpower aved when using the contect/pertial-resote maintenance schewe. Since contact work in the reactor bullding will add to personnel radiation dose, the number of contect man-daye 1s also calculated.

The sayinge in the unacheduled downtine par oper-

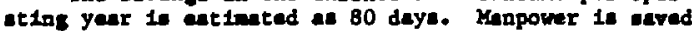
te the rata of 416 an-daye por oporating year (24-hr days). Contact work accouplished will require 104 andays per operating year.

\section{Sumery, Concluntons, and Recosendetione}

Two malotenunce plane ware analyzed for IMrOR. The firot enploye al1-reote antenemce operations and requiree no accese to the ranctor buildins at any tim during the useful life of the factlity. The other io based on a partially-resote plen that conbinas rewote. seni-remote, and contect operetions in epecific maluteance takk. The seat-resete and contact operation. are linited to coeponente that are loceted outelde the agnet bulk shiald. Exaplen are Inetrumatation and control equipaent, coolant 11nes, and pown leads. Maintenance tasks on conponeats inside the bulk shield envelope were ansumed to be carried out rewotely with the bedefit of semi-rmote or contact operations for some of the preparatory work (e.g. coolant lines and power leads diaconnecta/reconnact) when all ohield is in plece. A reasonably conwervative, but preliminary, analysis showe that for most of the critical path waintenance tasks $263 \%$ of the operations in the al1-remote scenarlo remain as fully remote while the other $37 \% \mathrm{can}$ be performad by contact or semi-remote means.

A major requirement of the partially-remote plan is for mintenance personnel to gein eccess into the reastor bullding a short time after shutdown to work in the reactor hall regions located outside the toroidal-field magneta. Wultidmensional radiation tranuport calculations and nuclear analysis shows that additional shield 1s required around all funct lonal equipmeat locatad at the outer end of all penetrations such as those for bean injection, vacuum pumping, divertora, and diagnostics. The amount, characteristics, and cost of this additional shield to reduce the blological dose rate in the reactor bullding to $<1$ mrem/hr at $24 \mathrm{hr}$ after shutdown were determined.

It was assumed that the radiation level 1a the only factor that determines the feasibility of human access into the reactor bullding. Therefore, it was implicitly augumed that: (1) the environment of the reactor buildIng is not contaminated with tritium, or nore opecif1cally mantenance personnel are not required to une brathing apparatus that could severely raduce the ir productivity; and (2) the environnent of the resctor bullding during maintenance perloda to norasl atr which 1uplias that either the reactor building is not evacuated under normal operation or, altermatively, it can be represeurized within the $24-\mathrm{hr}$ perlod allowed for radiative decay.

Table $V$ precenta a summary of the significant differences between no special shield/no personnel uccese plan and the partially-remote/additional ohield/ personnel access plan. The conclualone from this comparative ascessunt are:

(1) The partially-remote plan ignificantly raduce: the matatenance downt ine (acheduled plus unecheduled) by 120 daye per operating year relative to the allrawote plan. Therafore, the eatimated reactor avallablilty of 0.285 for the all-mintenance plan Increatea to 0.38 for the partially-resote plan. This 337 Ioprovement in evallability is the mont algnificant potential benefit of the partially-remote/additionel ehield/personnel sccess semario.

(2) The econonic penalty of the partially-renote plan is the capital cost of the additional thield around the ban 1njectors, vacuu pupe, and other functional aquipinat located at the outer and of penetrations. Aseuning neutral bease are ueed for plasea upplementery heat Ins and no divertor ia tacorporated the cost of ater1al, fabrication, and cooling of this additionel ohield is estinated to be w89 when the wat efficient ahtelding uterials are used. The corite and dieadventage of employins chaper but Iese afficlent hieldins waterialo euch es borated vater and concrete have not been ovaluated but could poes1bly raduce the ahield cuet ponalty. If the capital cont of IKTOR 1a in the range of $800 \mathrm{kS}$ to $1 \mathrm{BS}$, then the 89 us for the additionel ohield rapresente in in- 


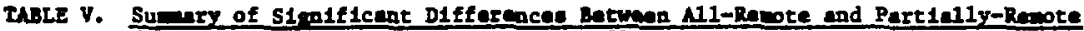

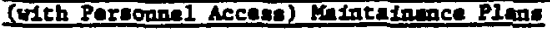

\begin{tabular}{|c|c|c|}
\hline & Al1 Renote & $\begin{array}{l}\text { Partial Rewote } \\
\text { (with Persoonel Accesa) }\end{array}$ \\
\hline Savinge in downtim, days per operating year & 0.0 & 120 \\
\hline Reactor ava1lability, z & 28.5 & 38 \\
\hline $\begin{array}{l}\text { Menpower requitranents: } \\
\text { Total person-hr per calendar year } \\
\text { Rudiet1on person-hr per celendar year }\end{array}$ & $\begin{array}{r}57,288 \\
0.0\end{array}$ & $\begin{array}{r}49,443 \\
1,963\end{array}$ \\
\hline $\begin{array}{l}\text { Cost Item, MS: } \\
\text { Capital cout of revote maintenunce equipment } \\
\text { Maintenence labor cost per calandar year } \\
\text { Cost of additional shield for personnel, } \\
\text { access with aeutral beans and no divertor }\end{array}$ & $\begin{array}{l}50 \\
19 \\
0.0\end{array}$ & $\begin{array}{l}45 \\
16.5 \\
89\end{array}$ \\
\hline $\begin{array}{l}\text { Increase in radiation exposure due to personnel } \\
\text { accesa (person-rea per calendar year) }\end{array}$ & 0.0 & 2.0 \\
\hline
\end{tabular}

crement in the capital investant of the facilit ty in the range of $29 \%$ to $11 \%$.

(3) With the lack of an established cost-benefit analyals wethodology, there are aufficiently convincing argunent: that suggeet the use of the ratio of the capital cost to avallability as a comparative figure for experimentel facilities auch a INTOR. The cost per unit benefit for INTOR with the partially-rewote/ add1tional ohield/personnel acceos oceario is $u 17 \%$ lower then that with the all-rewote/no-special shield/ noaccess maintenance plan.

(4) Another way to quantify the benefite of the partially-resote plan is to exanine the iapect on the allowable fallure frequency and the zequired zedundancy for the individual reactor components. Slace for a given failure the partielly-rewote acenario requires less downtiwe for repalr or replecement than the allrewote plan the fallure frequency can be allowed to be higher for the forwer for e fixed target avaliability. Alternatively, the required level of redundancy with the all-remo can be subatantially reduced with the partially-rewote plan. Examing the allowable fallure frequencies for individual reactor componenta in the all-renote plan show that they can be Increased by $340 \%$ for the partially-remote plan.

(5) The cost of the sdditional ohield for personnal accene 1s sensitiva to particular technology cholces. If a divertor ie incorporated on IMTOR the cont of the

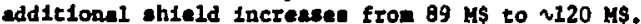
Replecing neutrel bean with if heating reduces the coet of this ahield from $89 \mathrm{ks}$ to $248 \mathrm{MS}$.

(6) Since 1t is imporatble to reduce the biological dose In the reector bulldins to zero, malntenance, persoanel working in the reactor bullding will recelve radiation dose. The additional ohield considered for the partially-remte plan is ouffictent to reduce the total cumlative dose to all mintenance persomel to $\checkmark 2$ pereon-red/colender jeer. Th1s is vore then two orders of arenteude lower then the radiation exposure to entenence peraconel in current fialon facilities.

(7) The partially-ramote alntenence plan hes favorable Inect on rescto: facility design requirewente, capital coat of mintenance equipent, and labor cout.
(B) Research and development requirenants for wintenance equipwent are extenalve for both the all-reote and partially-rewote mafntenance scenarlos. Bowever, the riske in the naintenance equipant developsent appenr to be sonewhat less for the partially-remote plan.

Important recommendations derived from the above conclusions are:

(1) The wost attractive malntenance scenar 10 appenrs to be the one that combines contact, send-retote, and remote operations so as to achieve an optioun benefit-tocoet ratio for the experimental facility. Finding this optinum should be a kay area that onst be addreased, in ail its aspects, in the INTOR development effort.

(2) The space in the reactor hall inolde the reactor contalngent bullding but outalde the maln bulk magnet ohield thould ba destgmed for personnel access within one day after shutdown. Material cholces and design options thet achieve this goul at a ninimun cost should be couprehenaively investigated. The feasibility of hield pluge for the mefor penetratione should be closely exemined.

(3) Alternativee to technology choicea requiring very large penetrations wuch as neutral beams and divertors ahould be serfously exanined.

(4) The trideoffe between the location of the vacuul boundary and maintenance plan ohould be inventigated.

\section{REFEREACES}

1. M, A, ABDOU, "Probless of Ruston Resctor ShieldIng," Georgin Institute of Technology, GIFR-10 (1979).

2. F. C. DAVIS, "Quel Proceesing Plant Design," Proo. Seminar on Ramote Syatems for Fusion Reectors, Oak RAdge Nationel Laboratory, Apr11 27, 1979,

3. B. S. BLANCHAR, JR., and E. E. LOWER, Maintainability and Practices (HeGraw-Hi11, 1969), p. 113. 


\section{sumgrang}

Twive problem areas of superconducting agnete for fuston resction are described. There are: quench Datection and Energy Dump, Stationary Noral Region of Conductor, Current Leada, Electrical Arcing, Electricel Shorta, Conductor Jointe, Forces from Unequal Currenta, Eddy Current Effects, Cryostat Rupture, Vecuum Fallure, Fringing Field and Instruentation for Safety. Priorities among these areas are suggested.

\section{Introduction}

This report calls attention to twelve areas requiring further study for the sefety of fusion magnete. It 1o based largely on the experience of the ANL Superconducting Magnet Group. The discussion deals directly with tokamak toroldal field (TF) colls, cryostable, cooled by pool bolling helium, with NbT1 superconductor and copper stabllizer. Each of the twelve areas is discuesed under the five subheadings: Identification and Definteton, Posalble Effects on Safery, Current Practice, Adequacy of Current Practice for Fusion Magnets, and Areag Requiring Further Analytical or Experimental Study. Under "Posstble Effects of Safety," consequences have been followed as far as the breaking or melting of the current path, excessive therwal stresses, or overpresturtzation of the cryostat. "Current Practice" refers to current practice as the author 18 aware of It at Argonne and alsawhere; there has been no extenive 11terature search or questioning of colleagues at other inatitutions. Finally, priorities for the recomanded experimental and analycical studies are discused. All of these topics are described in wore detail, and with references to related work, in Deference 1 .

\section{Quepch Detection and Energy Duas}

\section{Identification and Defintition}

A superconducting wagnet is sald to quench when - eaction of conductor goes from the superconductiog -tate to the normal state, the normal region generates heat, the heat drives more conductor normel, and the noriel region propagates unt1 a large part of the conductor is normal and the current has decayed. Quench analysis is particularly difficult for a lerge cryostable magnet. On the one hand, such a magnet is designed so that it cannot quench; cryostability requires thet there be aufficlent cooling and stabilizer avaliable that a normal region will shrink and diseppear racher than grow. On the other hand, there are fault conditions that could queach a mgnet, and large ezroutable engnets have been known to quench.

A quewch wast be datected early, and the energy of the engnet duped inco an external duap resistor. The diecherge voltege is the product of the magnet current and dusp resistance; if the discharge voltage is too

" Work supported by Ecec Idaho, Inc. and the D.S. Dapartent of Energy Iduho Operations Office under Contract DE-AP07-791000019. high, there 1e danger of electrical arcing. If It is too low, the dump will last too long; and the conductor can rise to too high a teaperature.

\section{Posalble Safecy Effects}

A high diecharge volcage can lead to electrical arcing; a slow dump can cause excesalve heating of parts of the coll, leading to unacceptable thermil stresses, or cause extensive helium bolling, leading to cryoutat overpressurlzation. A very slow dump or an undetected quench may allow the conductor to heat until it melts or until it decomposes the electrical insulation and arcs over.

\section{Current Practice}

A quench anslysis, for quenchea intelated by varioua faule conditions, will determine what discharge voliage 1s required for an acceptable temperature. The coil 1s designed for that temperature rise and that volicage. To detect a quench, the voltages across two halves of a magnet, which should be equal by the symuetry of the halves, are compared. If they differ by an amount corresponding to the voltage drop across a specified length of normal conductor, the magnet is discharged. As the normal region grows, more and more liquid hellum ig vaporized. The pressure in the eryostat Increases unt1l the pressure rellef valve opens, emptying helfum from the cryostat. Thereafter the quench propagates more rapidly.

The dump resistor should be permenently connected across the magnet terminals. In case of a quench, the power supply is disconnected and the manet discharges into the dump resistor; switches between the magnet and dump resietor cannot fall to close. The dump resletor should be of such a size that discharging the agnet w1ll not hent it excessively.

\section{Adequacy of Current Practice}

The methods curreatly used should be adequate, but the mesns of implementing those methode must be thought out. For example, the protection scheme must assure that the energy of all the TF colls is not dumped in the one coll which quenches. Moreover, the choice of digcharge voltage continues to be a compromise between high voltages and high temperatures; but it may be that a safe conpromise exists only for high currents, $50,000 \mathrm{~A}$ or higher. A quench anmlysis must be done to choose that compromise, but existing computer prograns for quench analysis are decidedly inadequate. Similarly, the quench analysis should determine how quickly a quach aust be detected and the discharge started. This Information in turn wold set the requiremente for the quench datection systen.

\section{Areas Requiring Further Study}

A general conputer progran for quench analyaso obould be developed for cryoutable agnets; no such progran extate today. The progran should be sufficlently ganeral that the properties of any particular magnet design could be readily inserted Inco tt. Quench detection, switching, and duap resistor design depand on the actual coll dealgn, and muat awntt the cholce of a deaign. 
Senetonery Horyel teeton of Conductor

Identifleetion and Definition

The previous eection explored the consequences of a propegating noral reston which dues not propeeate. In a cryontable magnet, e etacionary norwal reston can.eriee only fron a fallure of cooling of thet resion, elther fron a nasive blockese of the . cooling parages to the normil region or from the 11quid level falling below the conductor reglon. In each cane the region it cheracterized by cood bolling et exch and of the reston, preventing 1ts further growth, but poor cooling within the region.

\section{Poanble Sefety Effects}

The consequence of the etationary noral region depend on the tenperature difference which develops. If the temparature difference is hundreds of kelvin, tha electical Infulation can be damaged, perwitting tura-to-turn and turn-to-ground electrical shorts, and poasibly an overpressurization of the heliun vessel. Tor Interwediate temperature differences, thermal -tesses can result leading to possible mechanicel darage, etructure weakening, or Insulation destruction.

\section{Current Prectice}

No stable noral reglons have been observed in operating cryoutable magnets. Magnet degigne prevent wheh regions by preventing uncooled regions, 1.e, by preventing the liquid level falling below the top of the colls and by providing e network of cooling chunnele to prevent mantive blockage.

\section{Ideguncy of Current Practsce}

The large alze of the IP magnets and thatr ortencation in vertical plane wakes the potentinl problese from stationary normel regions wuch wore serfous then those with existing magnets.

\section{Areas Requiring Eurther Study}

The credible length for a noranl region is not know; It should be established both for force-cooled conductora and for those cooled by pool bolling. Mennwhile, an analysis should be done to deterwine the conequences of an uncooled length, for lengtha up to - half tura.

\section{Current Lesds}

\section{Identification and Definition}

Frobably current leads have been responatble for wre euperconducting agnet failures than any other caues. Each lead generally consiats of two parta: a normal lead frov room temperature to liquid helfum ceaparature, end a superconducting lead from the normal lesd to the argate 1tself. The lends experience the aymetic field of the angnet and so undergo a force, but their location ankes then difficult to support. Because of their location outside the coil, they are aleo subject to excessive heat Input and to ercing.

\section{Fostble Safety Effects}

Tatluce of a curtent lead wans a diecontinutey of current, with 11 the eafecy consequances that ateile. There will be h1gh voltages and posulble arelas, both at the lead that falled and throug hout the aygat oyaten. Large traneient forcen and addy curreat hating are 11kely. High theral streases, overpresurieacion, and maget destruction suy occur.

\section{Current Frectice}

The normel, gan-cooled leade ere typically procured comercially. Theee are ovelleble ulth current capecities up to $20 \mathrm{kA}$ or 60 . The principal efety practice is to monitor the temperature of the leada, the volcege drop acrose thes, and the ges flow through then, and to dump the nagnet if thene axceed preacribed 1inite. The leado mut heve sufficient excese copacity that if the gat flow stope, they can anely carry the aggat curzent throughout the agnet dunp. Safoty practice for the superconducting lead is to secure it wherever posulble, thu preventing motion, and to conitor the lead teaperature vie thermocouplas or potentinl tepe.

\section{Adequacy of Current Practice}

Thera are three areas in which the adaquacy of current practice wight be questioned. Elrst, the support of both the gas-cooled and the supezconducting leade may be more difficult because of the higher fielde and nore complex geometry of TF colls. Second, the wuch greater stored energy of a TF coll ayutem way require a longer dump time; and the leads must survive this longer dump. Third, currents of $50 \mathrm{kh}$ and higher have been proposed for TF collis; but ges-cooled lead of this capacity are not well developed.

Arean Requiring Eurther Study

An experimental program ahould be undertaken on high-current $(50,000$ A or more) leads with sufficlent excess capacity to suzvive a long discharge. Fortunately, such leads are largely Independent of the angnt dealgn.

\section{Electrical Arcing}

\section{Identification and Definition}

Electrical areing is another frequent ceuse of ouperconducting magnet fallure, 2,3 Arcing way occur between the current leads or between a lead and a grounded component, especially where the intermediate epace is filled with hellum vapor, which has a very low dielectric strength. It may also occur between turns, where the intervening insulation exhibits imperfections or has been daneged by overhesting, overstreseing, or radiation.

\section{Poatble Safety Effecte}

The enfety effects of arcing are severe; it cen lead to the destruction of the coll. Even if it does Dot, it any lead to shorted turne. If ercing ahorta out an entire co1l, It will lead to a force imbelance.

\section{Current Practice}

Areing ia avolded by uning fnauleting antertal with appropriate low tewpereture properties, and by anauring that nothing will break through the inouletion. Wher there is a potential difference ecrose a hellumf1lled apace, the gap must be wide enough; and the conductor mut be mounted firily to avold deflection which narrow the gap. After the anget is ascombled, It 1s checked againat arce to ground with a high voltege Inquintion breakdown teater.

\section{Adequacy of Curront Practice}

Iowlatiog ateriele, Includins heliu, exe not at well underatood as they thould be at liquid hellum teaparature; radiation effects on ineulation are oven lese well underotood. 
Arese Iequirtin Furcher study

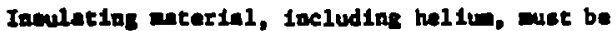
etudied in a almulated fueion reactor environant. A wiber of lavulatiog enterials utch potentially favorshle properties should be included in the teste.

\section{Hectrical Shorte}

\section{Ideactfication and Definiction}

Meetrical shorte can be ceuced by arclag, or by contect between conductors. Both turn-to-turn and curn-to-ground shorts can occur. Turn-to-ground shorts are lese likely to heppen, and a ingle turn-to-ground ahort in not eerlous if the coll is otherwise ungrounded or srounded only through a fure. The renalnder of th1s eection deals only with turn-to-turn shorts.

Fondble Effect on Safety

Contact shorts have 11tele effect on a auparconducting agret during steady atate operation. However, during the charging or discharging of the magnet, the chorted tura can have a large current Induced on it by trensformer action frot the changing flux through $1 t$, which can drive the turn to the normal state and cause overheating of the conductor.

\section{Current Practice}

During winding, a magnet coll can be checked for hhorte by both addy-current and ree1stance nechods, but cone ahnrta do not ahow up unt1l the magnet 1n assembled.

\section{Adequacy of Current Practlce}

The consequences of a short can only be determined by analysis and experiment.

\section{Areas Reguiring Further Study}

An anelyticel study must be performed for a partlcular agnet dealgn to determine what the consequencies of a contact ahort would be. Experimente can check the analyticel predictione.

\section{Conductor Joints}

\section{Identification and Definition}

Conductor jointa are elway potentially a sefety concern in a superconducting mignet. They can be in danger of mechantcal fallure, as well as serving as a reoletive heat Input; at least they are mechanically an irrogularity in the coll structura.

Intra-coll jointe, performed during coll vinding, include jointe between different grades of conductor. Inter-coll joints, performed during coll asrembly, include joints betwaan cotls or between pre-assembled portions of colls, e.g. pancakes. Intra-coll joints cen be ande under almost Ideal conditions in the uindins 11re, wth whetever spuce to needed for fornting and Iaspecting the jointe; while 1nter-coll jolnts ant be ande and Inspected in the process of asembling the colls.

\section{receible Effecte on Safoty}

A poorty bonded foint or a foint in which one stde protrudes out of the coll and can be sheared off when the coll is energized can lend to a current diecont1wity. A joint with good machanicul strangth but high ilectrical zesiatence causes heatins and way produce a inget quesch.

\section{Current Practice}

Techniques by whlch uafe jolnt can be ande Include: voldering, cold walding, reniatance welding, ultracontc velding, explosive velding, and electronbew welding. Any of these could be incorporated in the uindins operation for Intra-coll jolnts, but spac 1iatertions ay preclude sone of them for the interco11 joints. Inepection sethods include ultrasonic and $x$-ray, plus resiatance meseuremente of completed jointa. Acceptable jointe wut reet the criteria of electrical reasetance and aechanical atrength.

\section{Adequacy of Current Practice}

It 1. by no meant clear which tachnique of aakin folnts is most likely to produce anfe, reliable joint in extens 1ve development progran is required.

Arene Requiring Further Study

Once a conductor concept, or a onll number of different conductor concepts, 1s chosen, development work should begin on deterwining the best way to make safe Intra-coll jolnts. Subsequently, work should be done to adapt that method to Inter-coll joints, or to find a method that can make safe inter-coll joints.

Force from Unequal Currents

\section{Identification and Definitions}

If the TF colls of a tokanale are perfectly allga and all carrying the same current, they exert only a centering force on each other, withatood by the centr aupport cylinder. The misalignment of the colls expected in assembly introduces out-of-plane forces on each co1l, but these forces ${ }^{4}$ are smaller than the out of plane forces due to the pulsed pololdal field. Hor ever, a large current inbalance awong the TF colls would lead to very large out-of-plane forces whtch te to pull the colls together like an accordian.

\section{Posable Effects on Safety}

It 1. herd to Imagine a worae accident in a toka reactor than the TF collo collapaing togethar. Cryoatat rupture, vacuum fallure, electrical discontinuity all would result, with all their subequent dangers.

\section{Current Practice}

te no suparconducting TF colla now exist, it is more accurate to speak of current planning rather then current practice. Two approaches may be taken to thit proble. One 1s to provide an outer atructural shell connecting the IF colls and sufficiently strong to withetand the forces produced by any combination of currents in the coila. The other is to operete the coll. In serles; operating in serles, the colis nust carry equal currents, and there is no force problen.

\section{Adequacy of Current Practice}

The aeries current approach is advantageoun, provided the current cannot arc acroes an entire coll or any turne of a coll, bypassing the coll and providing fiald itbalence anong the colle.

\section{Areae Requirige Further Study}

A careful anclytical atudy should be carrled out to see if it is posetble to desiga and butld a coll which ts not ubject to thortins out. Such atudy alght then define soes key exparinentel queations which wet be anvered before the cholce can finully 
be eade between the two appronches to forces from unequel currents.

\section{Eddr Current Effects}

Identifleation and Definition

zddy currente are produced by the pulsed polo1dal field colla. More severe eddy current problens will be produced by any rapid unecheduled incerruption of the toroldal field, poloidal field or field from the pluase. Eddy curzent effects occur not only in the agenet thearelves, but $\mathbf{1 1 0}$. In the eupport atructure, cryoseats, and other systeas of the reactor wuch as the blanket and shield.

\section{Poesible Safety Effecta}

Bddy currents can cause hcating, forces and torquei both in the agnet syoten and in other ayscens of the reactor. Wichin the cryoutat, the heating 1. a denificant problen as it could vaporize helfum and overpreasurize the cryostat or could quench the arnet. The forces and torques are a problem both instide the cryoutat and out.

\section{Current Practice}

Where changing fluxes occur, poorly-conducting - aterials prevent eddy current effects. If a conducting material is required, it can be segmenced to 1int eddy current paths. For example, the nitrogen shield can be made from multiple segments.

\section{Adequacy of Current Practice}

The fleld fron the fusion nagnets engulfs the entire reactor. The eddy current effects can occur throughout the reactor. The design of all systems mist take eddy current effects into account.

\section{Aress Requiring Further Study}

Idy currents occur In wany parte of the reactor, and differ fron system to syseen and from one reactor dasign to another. To analyze chem, one of the seneral purpose eddy current programs, such as those under develgpgent at the Rutherford Laboratory 5,6 and Argonne 7,8 sould be adapted to fusion angets.

\section{Crrostat Rupture and Vacuun Faflure}

\section{Identificetion and Definicion}

Obviously a cryostat should not rupture; but a eryostat rupture is conceivable through overpresaur1zetion, excensive wechanical otress, penetration by an object or the sheering off of tubing to the cryoacat. Cryostat rupture and vacuu fallure ara interrelated; alther can cause the other.

\section{Posedble Safety Effects}

A rupture shich allowe heliun or sir into the vecur can result in rapid heat transfer frov the outer cryostat wall to the inner or hel fus temparature vil. The preasure in the holiun opece and vacuu apace will riea, and the eagnet an quench, which in turn will result in wre heting and presmurization. $\Delta$ dengerous fallure of the engat system to posable.

\section{Cusrent Practice}

Doth the heltiv voseal and the vacum opace sunt be equipped with praseste relief valven or rupture dielse to prevent overpresenrisation. These mut lead to vent plping alzed so that a low preseure sradient can epty the veaunl quickly.

\section{Adequacy of Preqent Prectice}

The heliu veseel to larger and nore complex for the fusion menets than for any existing magneta. Only a thorough analyeis can deteralne what aust be done to prevent serious consequences. It any be necessery to provide separace hellum vessel for each co11, Ithough thi. would greatly complicate the aupport of the coll and would certainly Increses the heat load of the systed.

\section{Areas Requiring Furcher Study}

Analyeid of hent transfer and presure bulldup and rellef should be carried out for the hellum veasel and vacum space for a typical fusion reactor design. This should determine whether a comson hellum system and common vacuum for all colls $1 \mathrm{~s}$ acceptable. All potential causes of cryostat rupture and vacuum fallure should be studied as vell.

\section{Fringing Field}

\section{Idencificacton and Definteion}

The TF colls will produce a weak fringing field, but one extending far from the magnets. The pulsed field from the PF colls will be even higher.

Posalble Effects on Safety

There are three possible effects on safety: disturbance of Instrumentation with consequent malfunction, attraction of iron objects to the magnets with possible penetration of the cryostat, and effects on personnel. The first two of these are readily dealt with in a atraightforward manner, but the effects on personnel are bard to specify, because there is so litele ev1dence of biological effects from low flelds. S. J. St. Lorant ${ }^{9}$ in his extensive review on biomagnetic effects concludes that magnetic effecta are fully reversible and that there are no data which indicate a cumulative ef fect.

Pregent Practice

An advisory cownittee to DOE has recomended 10 Interin Stendards for Occupational Exposure to Conetant Mignetic Fields; these appear in Table I.

Toble I. Interin Safety Standards for Consent Wagnetic Fields

\begin{tabular}{|c|c|c|c|}
\hline & $\begin{array}{l}\text { For an } \\
8 \mathrm{hr} \text {. } \\
\text { Work-Dey }\end{array}$ & $\begin{array}{l}\text { For } \\
\text { Expoaures of } \\
1 \text { hr, or lese }\end{array}$ & $\begin{array}{c}\text { For } \\
\text { Exposuras of } \\
10 \text { min. or lese }\end{array}$ \\
\hline $\begin{array}{l}\text { Whole Body } \\
\text { or Head } \\
\text { Exposure }\end{array}$ & 0.01 Tesia & 0.1 Teala & 0.5 Tesela \\
\hline $\begin{array}{l}\text { Exposure of } \\
\text { Extrenteies }\end{array}$ & 0.1 Tasle & 1 Terle & 2 Tesla \\
\hline
\end{tabular}

To prevent accidents from Iron objecte, the check14et for anget charge should include thoroush chack for lron abjects asch tine the wagnets are charged. 
In the bance of new data, the present practice proviatonally can be considered adequate. Any fuston renctor deniga ahould include a mp of the fringe field from the IF and PF colle.

Areas Requiring Further Study

If there is a question about the adequacy of the Interie Standarda, or if obeerving then would plece a hardabip on fucton reactor operation, then an experimatal progran should be comissioned to find the meded date that do not yet exist.

\section{Inetrumentation for Sefety}

\section{Identification and Definition}

Proper instrumentation 1s required to monitor and respond to the safety concerns discussed in the previous sectlons. Tenperature sensors, potential leads, strain gauges, liquid level indicators, and Instrumentation for the leads must all be chosen so that any fault condition can be detected quickly, analyzed, and inforned action taken.

\section{Poasible Safety Effecto}

Probleme such as abnormal forces between coils. a propagating or stationary normal length, an uncooled length, an overheated or uncooled lead, an electrical ohort, high pressure in the cryostat, or a poor vacuun cannot be corrected without sufficient rellable ingtrumentation to inform the operator what is happening. The cholce of instrumentation 18 an important safety convideration.

\section{Current Practice}

Exfuting large cryostable magnets are extensively Instrumented for safecy. Temperature sensors and potential leads are located in the coll reglon. Strain pauges are located in the coil and in the structure were high or anomalous stresses may occur. Liquid level Indicators tell when the level is in danger of falling below the top of the coll. The leads are checked for temperature, voltage drop, and gas flow. On the basis of this information, approprinte action is taken. In case of a severe problem, the magnet is discharged. In case of sowe external problems such as power supply problems, the magnet 18 awitched to a "Exee-wheeling" state in which the mgnet terminela are comected together, the power supply is discomected, and the mignet continues to operate but with - very slowly decreasing current. For less severe problems, a visible and audible varnigg is given so that the problen will be noticed and corrected.

\section{Adequacy of Current Practice}

The current philosophy of instrumentation for enfety atem adequate, but the choice of sensors vill be unique to the fusion reactor. The angets are so closely located to the reat of the reactor that the apet nust be ande to respond to problens in the other aysteme and vice versa. In addition to other ingtrumentation, it any be desired to nonitor radintion doase at the coll.

\section{Arees Requiring Further Study}

in anclyais of the instrumentation requiremente for funton megets should be asde. The object of soch - otudy wold be to find arese in which exteting eeneora ste indequate. Suttable onas wet thea be developed at raluated.
The above list of safety concerne in by no mean complete, but it does include thowe that have been of concern to the Superconducting Mingret Group at Argonne, The highest priority should be atteched to those areas which are very inportant, need to be deternined arly, and are virtuolly desiga independent.

1. The developent of a computer progran for the quench anslyaie of cryostable fuslon angete.

2. Devalopent of a general purpose progran for eddy current calculations applied to fusion agnets.

3. Antysia of series-connected TF colls, to deternine if a credible aceldent could cause thein to carry unequal currents.

4. An experitental progran to develop current leads of capacity above $50 \mathrm{kh}$.

5. An experimental siudy of the behavior of electrical insulation under radiation at cryogentc tenperatures.

\section{References}

1. L. R. Turner, "Safety of Superconducting Fuston Magneta: Twelve Problen Areas," Argonne National isboratory, ANL/FPP/TM-121 (May, 1979).

2. S. Y. Haieh, et al., "A Survey of Fallure Experience in Existing Superconducting Hagnet Systems and its Relevance to Fúton Power Resctors," IEEE Trans. Maga. MAG-13, (1977), 90-93.

3. D. Bruce Nontgowery, "Superconduct1ng Magnets: there Did We Go Wrong," Stxth Syeposium on Eng1neering. Problens of Fustion Research (San Diego, 1975), PP. 122-127.

4. W. H. Stacey, Jr., et al., "Tokanak Experinental Power Reactor Conceptual Design," Argonne National Laboratory, ANL/CTR-76-3 (Auguat, 1976), PP. IV -46 - IV -63 .

5. C. S. Blddieconbe, C. J. Collie, J. Simkin, C. w. Trowbridge, "The Integral Equntion Wethod Applied to Eddy Currents," Proc. of First Covpuma Conference on the Conputation of Kagnetic Fields (Oxford, 1976) PP. 363-372.

6. C. S. Blddlecombe, "Developwents in the Rutherford Laboratory Eddy Current Prograns, "Proc, of Second conpuns Conference on the Computation of Hagnetic Flelde (Grenoble, 1978), p. 3.5.

7. L. R. Turner and R. J. Lar1, "Devalopaents of the Iddy Current Program EDDYNET," Proc, of Second couruma Conference on the Compueation of Magnetse Flelde (Grenoble, 1978) p. 4.4.

8. L. R. Turner, "An Integral Equation Approach to Iddy Curzent calculations," IEEE Trans. on Hatgetice, Vol. MAG-13, 1977, Pp. 337-345.

9. S. J. St. Lorant, "Blomgnetian: A Revlew," S1rth International Conference on Kagnetic Techolory. (Bratieleva, 1977), PP. 337-345.

10. Z. L. Alpen, Uatvereity of Californie, Berikeley, pereonal comunication. 
Overeurrent Frotestion for ibe TFIR Neutral Jeam Sources During Spark Dow*

\author{
W. 5. ?reeg \\ Argenne National Laboration \\ Argonne. IL 60439
}

Sumary

"The accelerating grid of a noutral beam source (UES) of the Toloamak Fuston Test Reactor (TETR) operates $3: 120 \mathrm{kV}$ and $65 \mathrm{~A}$. The capacitance to Ground bevween the switch tuoe (ST) and the NBS is $C_{1} \sim 5 n F$ $\therefore 36$ I!. The are and fllament power supplies for the IRS iloat $35120 \mathrm{kV}$ and have a capect tence to ground of

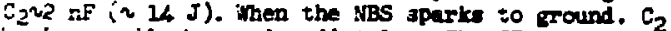
bezins to discharge inediately. The ST ileadence Inits the fauit current from the high voltage (UV) poirer suppiy io $\sim 100 \mathrm{~A}$ intil it disconnets the poner source < 2 us aiter spark dom. In cese the ST ralls, 3 crombar removes the poner source $\sim 4$ us after spark tom and $C_{2}$ begins to dischare. During spertk down, 'ault eurrénts are limited with e seturated time-delay iransformer (STDT) connected betwen the ST and the NES and riti 3 snubber, which is in the are and fllament jower leads, in connection with a spark gep. Altarnatively, SIDT's can be uned for the HY and for the are and filement power Ieeds. This paper presents desten dotalls and experimental results of the overcurrent protection ilreuits.

\section{Introduction}

The accelerating and the gadient grid of an vBS operate at very high roltages and nust be protected from dange by occasloanl sparks to ground. In the murar of 1075 I proposed an STOT to linit the fault curreat during sperk dow. 1,2 The STDT is cometed in aries ath the iv source. W. R. Baker of the Inwence Berkeles Inboratory ${ }^{3}$ reported in 1976 that toroidel s0-50 MfFe tepe cores can be uned as coe-turn "mubbers" to I1-ft feult currents. In 1977 I proposed thet operk sape and resistors in conjunetion of th on SIDT and reverora be used to shut not of the diechurge netre any from the NAS. 4 on the buris of this propoeal tho prototype circuits are belng developed to protect the riBS's of the IFTR.

In the efrouft of Fle. I en SzOr linte the current to the scceleretion (eccel.) and gredient exlds of the NBS. During nowel oporetion the ST wII open the pown circuit in $<2$ us, thereafter capacitor $C_{I}$ dlsoharres. In case the ST fafle, a crobar sbort clreutta the powr source $\eta 4$ us artar the JBS eperked to ground. Thy

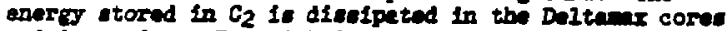
and In resiutor $\mathrm{B}_{2}$ witch is corrocted in perallel to the Deltamax cores we apark bap $G$ Is trigrered by the STIP.

In the cireut of Fig. 2 the con-turn Deltang core has been ropleced by Iilti-turn Siloctron cores. Silectron coren are lese erfleleat but aloo resy weh less expenalye then Deltarix corve. Wh silectron cores and wit1-turn Findinge, the tits delas and clrcult inpedance can be increased cococolcelly, theroby elfotneting the noed for the epark ap etreutt.

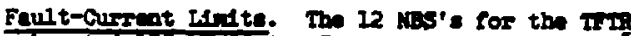

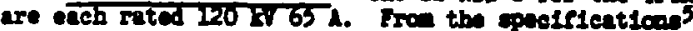
for the NBS a fer of the nar requiremente are teted s. follow:
Turs-off tion arter raut

Interrupt duration arter fault
$<10$ w

5 to 50 .
Finge supported by the 0. S. Departinet of Denter

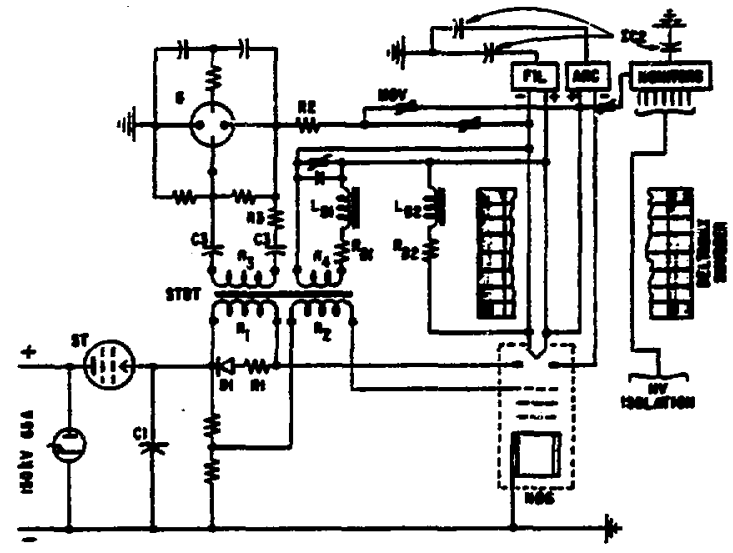

F18. 1. NBS Protected by SIDT, Suubier and Spark Gap.

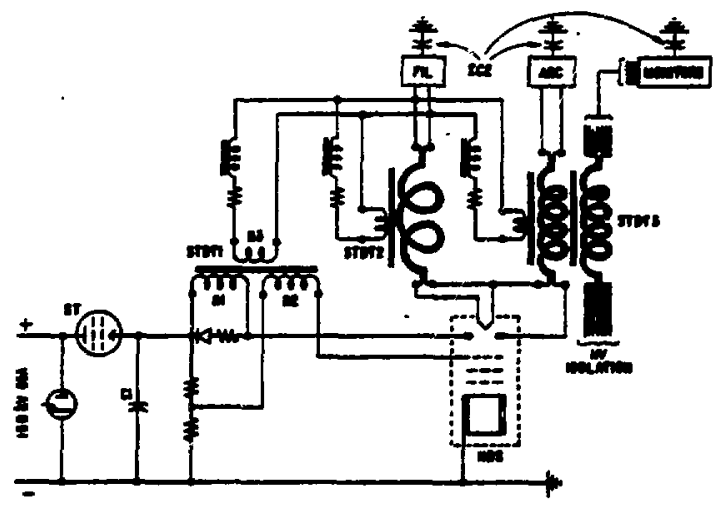

Fiz. 2. NBS Protected by STOT'a.

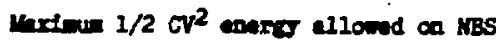
olde of protection circult

3 ร,

Vaxtan 1/2 $\mathrm{Cr}^{2}$ enoros allawed on power supls side of protection elrefut

$15:$

Wadim fault current perndted by protection circult one and sbove opervetine curroat

$200 \wedge$

The cbove 11nte the diecherge to $\int 1 \mathrm{~d} t \leq 265 \Lambda \times 10$ us - $\leq 2.65$ As and the cepnetiane of $2.1 \mathrm{nF}$. 20 Ppecifleation do not mattion $\int 1^{2}$ dt vilues. For the his of the IJIR whe he $C_{1}=5 \mathrm{nF}(36 \mathrm{~J})$ and $\mathrm{C}_{2}=2 \mathrm{nF}$ $(14.4 \mathrm{~J})$ whteh excende the destred velue of $15 \mathrm{~J}$ by 2 fretor of 3.36. Flonver, thore should be no idnit set to the 1/2 $\mathrm{Cl}^{2}$ ellowd an the power suppls stat of the protectica clreult as low as the protection elreult bolds the foult eurrent to sepe nives. 
Filiure lodes. The isilure aode of the are and

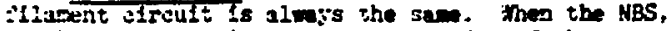
scarks. the canacltance to seound, $\mathrm{C}_{2}$, or the arc and Ifisment :ransiormer assembly segins tc discharge. The frid ifrcuits can have three iallure sodes. First, juring normi operacion of the protective circults, a spark tom auses the $S T$ to disconnect the $\mathrm{FV}$ supply Fitilin 2 us. thereafter apecitor $C_{1}$ discharges. Sacond,

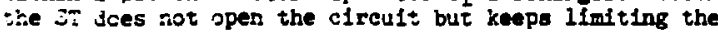
suzrent. In this case the crowbar is activated within +.3. Thls removes the HV source and capacitor $c_{1}$ se $e^{-1}$ s to discharge. The worst fault condition exists if the ST sparixs over when the NBS sparies to ground. The Si no -onger limits current and causes capacitor $C_{1}$ :o be sharged to $150 \mathrm{kV}$ for 4 us unt1l the crowbar shorts the iv source.

Lidt versus $\left(1^{2} \mathrm{dt}\right.$. In the past only the peak values of tharge (AS), energy (J) and current $(A)$ have been specifled during fault conditions. For a given spark dcw resistance of a NBS, the enercy dissipated is propor:ional to $\int 1^{2} \mathrm{dt}$. Therefore, dischareing eiven arount of coulowbs through as large an Impedance, connected in series with the NBS, as practicable will cause tibe lenst amount of energy to be disalpeted in the NBS. For example discharging $2 \mathrm{nF}$, charged to $120 \mathrm{kV}$ into a $200 \Omega$ resistor resulte, $w$ th $\mathrm{BC}=\tau=0.4 \mathrm{me}$, In $\mathrm{a}$ ischarge curreat of

$$
1=I_{p} \exp (-t / \tau)=600 \wedge \exp (-t / 0.4 \mathrm{\mu a})
$$

Toe total discharge is

$\int_{0}^{\infty \mathrm{d} t}=I_{\mathrm{p}} \mathrm{t}=600 \mathrm{~A} \times 0.4 \mathrm{us}=240 \times 10^{-6} \mathrm{As},(2)$ and for $1^{2} t$, we here

$$
\begin{aligned}
\int_{0}^{2} \mathrm{dt} & =I_{\mathrm{p}}^{2} \tau / 2=600^{2} \Lambda^{2} \times 0.4 \mu \varepsilon / 2 \\
& =72 \mathrm{~m}^{2} \mathrm{~s} .
\end{aligned}
$$

If we now trerease the restatance by a factor 10 , fidt does not change, but the discharge mill have 44 us tim constant and a pack current of coly 60 A reoulting in a 10 times andier $\int 1^{2} d t$ of

$$
\int_{0}^{\infty} 1^{2} d t=60^{2} \times 4 \mu s / 2=7.2 \mathrm{u}^{2} \mathrm{~s} .
$$

of course the enerey diestpeted is $14.4 \mathrm{~J}$ is efthor case. Howrer, the boet diesipetion 10 to times enizer. It is reccumoded thet the speciflcetion for fault currents include velues for $\int 1^{2} d t$.

\section{The Soubber Dento}

\section{The Infitial current Step in Deitenax}

Without sparis ap $G$ and realntor $h_{2}$ the dischnry clreult for cepacitor $\mathrm{C}_{2}$ is the soubber clreuft firat proposed by $\%$. Baker. 3 It une odd-cussent lonese is Deltenex cores to lint the curreat. The exuivintent clreult is included in Fis. 4 . Th ofreult in baend on a paper by winter ot al.6 Part of thet paper reporta on inftiel cursent otop mengurements on toroldel cores of $50-50$ MiFe tape with the remith that

$$
Z=5.656^{1 / 2} \text {, }
$$

whore II = Inftial stop in Expotic fleld it the curfece of a wap of tapa, in 0 .

E - cedient of the inltiel step roltage

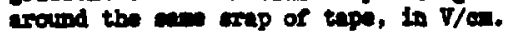

The authors found that xos of the pood sores jested were within $50 \%$ of tise value given jy Eq. (4). Converting de into $\mathrm{A} / \mathrm{cm}$ :ve 3 in mite

$$
5=\frac{5.55}{3.1 \pi} \xi^{i / 2} \times 4.5 \xi^{1 / 2}=\frac{1_{s} n}{i_{F e}}
$$

where $1_{s}=1$ intial siep in excitation surzent. In $A$. $\mathrm{n}=$ number of surns an the excltation ecti.

and

$$
\ell_{F e}=\text { length of magnetic slux fath, in cm. }
$$

From Eq. (5) re obtain the initlal step surrent

$$
1_{s}=4.5 \frac{l_{F}}{\Omega} \xi^{1 / 2} \text {. }
$$

The average inftial voltage gradient on the leninations of a tape wound core is

$$
E=\frac{E}{2 \pi \text { in }} .
$$

where $E=$ step voltage spplled to the excliation coll, in $v$.

w Wldth of the core laninations, in $\mathrm{cm}$,

and

$$
N=\text { total number of laminations }
$$

Conbining Eqs. ( 6 and 7 ) results in

$$
1 .=3.18 \varepsilon_{\mathrm{Fe}}\left(\frac{E}{\operatorname{tin}^{3}}\right)^{1 / 2} \text {. }
$$

The realstance ralue of the core, equivelent to the Inftial step response, is

$$
R_{s}=\frac{5}{I_{s}}=\frac{0.314}{T_{T e}}\left(\operatorname{sinim}^{3}\right)^{1 / 2} \text {. }
$$

The realatence, equivalent to eddy-current lonses, changes with tim.

\section{The Initial Current Step in S1Iectron}

Al Schofield of Los Alems Sclentifle Iaboratory took experimetel dete on the step responss of 1 -ell silectron. Fron these andeurements a velue of

$$
\text { H }-14.8 \varepsilon^{1 / 2}
$$

In $\mathrm{M} / \mathrm{C}$ a we determined by Vincent Cheng of Gulton

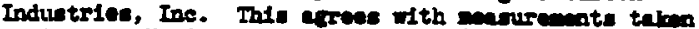

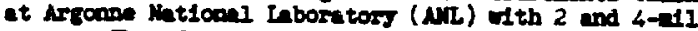
cores. Therefore, for Silectron, the equetions for $1_{s}$ and $\mathrm{A}_{\text {, becone }}$

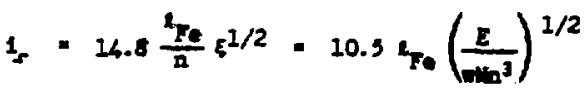

and

$$
R_{s}=\frac{0.095}{L_{T}}\left(\operatorname{Lim}^{3}\right)^{1 / 2} \text {. }
$$

\section{Dechare Equations}

Irperimate at $\mathrm{NL}$ hore abou that the tIo reoponese of the Inftiel curruat an be prouped ss follows:

e. The curreat desara apgroxinteis in a strefght Ifne (FIs. 9n)

b. It hither onotien the current deeng with a Iros wt shop (FIT. Ba)

o. In curgat Fiese meh above its inftial vilue (Fie. oe). 


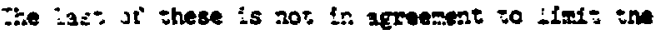
zur:ent to siose to 1ts ir.itial step and. thorefore, not senstiered ing further.

The Surrent Lecays inderly. At relstively 10w ener:ies. The surrent deiay can be spproximated $x i t h$ s $y=3$ initine

$$
(1 t)=1-\left(1-\frac{\tau}{T_{1}}\right),
$$

where $m_{t} \neq$ ithe wisen curzent is zero.

The capacitor voltage is given by

$\left.E_{c}: t\right)=\Sigma_{0}-\frac{1}{t} \int_{0}^{t} 1 d t=s_{0}-\frac{t_{2}}{\tau} \pm\left(1-\frac{t}{2 T_{1}}\right)$,

minere $E_{,}=$voltage an sapacitor $C$ at $t=0$.

From $\equiv q_{1}{ }^{\prime}(14)$ the diactarge time, $t=T_{l}$, is, for $e_{C}$ $=0$,

$$
\tau_{1}=\frac{2 C E_{0}}{i s} \text {. }
$$

The roltseconds ( $\mathrm{V} / \mathrm{s}$ ) the snubber mast support are

$$
f(t)=\int_{0}^{t} e_{c} d t=E_{0} t-\frac{1-t^{2}}{2 c}\left(I-\frac{t}{3 r_{l}}\right) \text {, }
$$

which, at tiwe $t=T_{1}$ becomes

$$
\Phi_{I}=\int_{0}^{T_{1}} d t=E_{0} I_{1}-\frac{1 s T_{1}^{2}}{3 C} \text {. }
$$

The beat generated is proportionel to

$$
\int_{0}^{t} t^{2} t=1_{s}^{2} \int_{0}^{t}\left(1-\frac{t}{T_{1}}\right)^{2}-12 t\left(1-\frac{t}{T_{1}}+\frac{t^{2}}{3 T_{1}^{2}}\right) \text {. }
$$

and et the end of the pules in have

$$
\int_{0}^{m} 1^{2} t=1_{s}^{2} \frac{T_{1}}{3} \text {. }
$$

The above equation are plotted an a per unft bals in E5. 3.

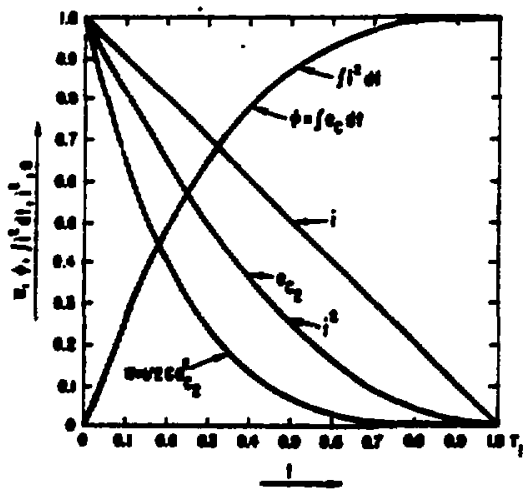

FI. 3. Linosr Current Deery.

The Curset Deang Pollow $(1+$ sol ut). For a current abpe cocortied of

$$
I(t)=0.51_{s}(1+000 \omega t),
$$

the cepecitor roltere becenen

$c_{c}(t)=z_{0}-\frac{1}{c} \int_{0}^{1 d t}=z_{0}-\frac{1 s}{2 c}\left(t+\frac{1}{t} \sin \omega t\right)$, and Nth ec $=0$ for $t=T_{I}=\frac{\pi}{4}$, we find

$$
\tau_{1}=\frac{2 E_{3}}{1_{5}}
$$

with is the save as Eq. (25).

For the Dux we have

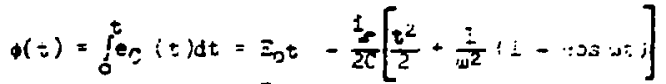

which, at $t=\tau_{1}=\frac{\pi}{\omega}$, is

$\omega_{I}=E_{0} T_{I}-\frac{I_{S}}{2 C}\left(\frac{\tau_{1}^{2}}{2}+\frac{2 T_{1}^{2}}{\pi 2}\right)=E_{0} T_{1}-\frac{0.35 I_{s} T_{1}^{2}}{C}$

Finally, we find

$\int_{0}^{t} 1^{2} d t=\frac{1 s^{2}}{4}\left[\frac{3 t}{2}+\frac{1}{\omega}\left(2 \sin u t+\frac{1}{4} \sin 2 \omega t\right)\right]$

whleh at $t=T_{1}=\frac{\pi}{\omega}$ becomes

$$
\int_{0}^{T} 1^{2} d t=\frac{3}{8} 1^{2} T_{1}
$$

The above equations are plotted in Fig. 4.

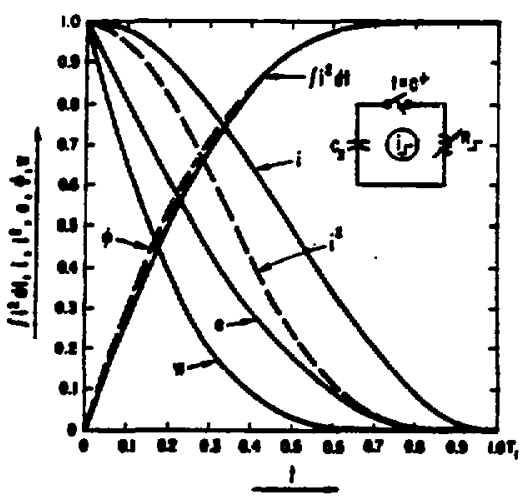

Fig. 4. Current Decay Followe $(1+\cos \omega t)$.

The IrIR Deltanx Smubber and Spark Gap Clrcust

The Diltare Ctroult. is show in F1g. 1, the baen beses of the are and filenent circults, towhar with the cabled of the maltoring clreuled, fort - aos-turn oreitetion coll for the Deltamx snubber. The aubber is biased to -0.2 on with a con-turn winding. Wan the MBS gparke to cround, tho $120 \mathrm{kt}$ on capector $C_{2}=2$ nF excites the nubber cores. Subber detello are ofree in Iable $I$.

Table I: For 120-rV Sumber core Mucibly

Bo. Deltanx coren

$\infty$

ID

BusIdup

Tape iddth

Tape thiclenen

Stecling fector

36

$25.0 \mathrm{~cm}$

14.5

$\mathrm{b}=5.24 \mathrm{~cm}$

T. 1.27 an

d $.2 .54 \times 10^{-3} \mathrm{em}$

No. Trape in ecombly $N=36 \mathrm{bu} / \mathrm{d}=5.57 \times 10^{2}$

Averes roltape fredicat on wrepe $E=0.848 \mathrm{~V} / \mathrm{cm}$

Voltere betimen mepe

$2.15 \%$

valin leath of Mux path

Croes aren of acembly

Cost of 36 corves $\$ 310 /$ cort

$L_{T}=61.3 \mathrm{a}$

$\$ 11,160$ 
The :apes are dekurred and double-coated. Each sore is in $a$ nyion sase and cushioned alth dlelectrls é: IF-jj-j:3 of ihe Dox Corning Carp. Fron Iq. iz) the fnitiai zurrent 3 tep is $i_{\mu}=256 \mathrm{~A}$. From Eg. (15), ine discharge ine is, $i_{2}=1.38$ us. From Eq. (23) the sore sssembly must suppost a toral $\mathrm{rlux}$ of of $\tau_{7}=0.067$ 75. :ie average voltage during the discharge is $V=$ $\mathrm{T}_{-} \mathrm{T}_{-}=0.357 \mathrm{Vs} / 1.98 \mathrm{:s}=35.8 \mathrm{kV}$. W1th a flux density

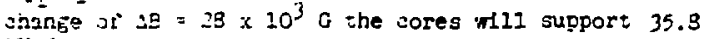
it : :or

$$
\begin{aligned}
s t & =\frac{n A(\Delta B)}{\sqrt{x}} \quad \text { (26) } \\
& =\frac{180 \times 28 \times 10^{8}}{35.8 \times 10^{3} \times 10^{8}}=2.40 \mathrm{us} .
\end{aligned}
$$

This Salls 258 short of $T_{1}=1.88$ us. However, as is shom Iater, the spark gap will shunt most of the disoharge away from tine NBS and into $\mathrm{A}_{2}$ in less than $100 \mathrm{~ns}$ after the NaS has sparked down.

!'le see from Fig. 4 that after $100 \mathrm{ng}\left(0.05 \mathrm{~T}_{\mathrm{f}}\right)$ not much enezgr CAs passed through the NES. Because of the quick response of the spark-gap circuit, we can reduce the gmoun: of core terial. For example, by cutting the tape : rldth in half, we would keep the same volts/mrap. The gradient $\bar{z}$ would double, causing 1 to Increase by $42.4 \%$ to $362 \mathrm{~A}$. With half the area, the rolt-second rating of the core assembly would be cut in half to $25 \mathrm{~ms}$, winich st1ll provides a large safety margin.

The 3las Circuit. During normal operation a de blas current of 12 A generatea 0.2 oe on the outer mrap of the snubber corea. This current also causes a dc flux of $5 \mathrm{kG}$ in the cores of blan choke Laz. A short time af ter the NBS sparke to ground, this bias circult is by transforwer action, connected in parallel to the snubber impedance. Choke $\mathrm{L}_{\mathrm{B} 2} 1 \mathrm{~s}$ dimenstoned to keep this additionel fault current amall and to absorb the voltage across $C_{2}$. The voltage divider made by $I_{g 2}$, $R_{B 2}$, and the paraliel connection of a diode and a metal oxlde varlator protects the bies rupply from transient voltages.

\section{Table II: Detalls for 120-rV Bias Choke}

Elght Silectron coreg AL-1463 wth $N=8 \mathrm{bs} / \mathrm{d}$

"lidth of Larination

No. of turns

Volts/turn $=120-\mathrm{kV} / 13$

Volts/lamination $=9230 / \mathrm{N}$

Voltage gradient on lamination

Iength of Mux path in iron

Length of Mux path in afr gap

DC Induction

Under worat conditions (perfect coupling between the primary and secondery turne) we would have a current step in the blas clrcutt when the NBS sparks down. From Eq. (11) the current step is $1=33.2 \mathrm{~A}$. This current adds to the 124 bies curreat. Howner, the pulse permability of S1lectron 7 is very auch inder then the de perinbility. This caues the Rlux deasty to Increase alow nouch to atey well below seturetion during the dincharge putse. The cores wese selocted on the beals thet the rolie/lamination be $-2 \mathrm{~V}$. This voltage requires double conting of the lentontion (a carlite cont followed by a menesiun wethivte cont). The turns were wound. with RG-17 cable wth the breld removed, and the coll eseesbly was veculn impregneted with epory reatn.

\section{Test Results}

The Deltarax snubber sag tested in the circuit of Fis. 5. The arzanement of the alrcult components is shown in Fig. 6 .

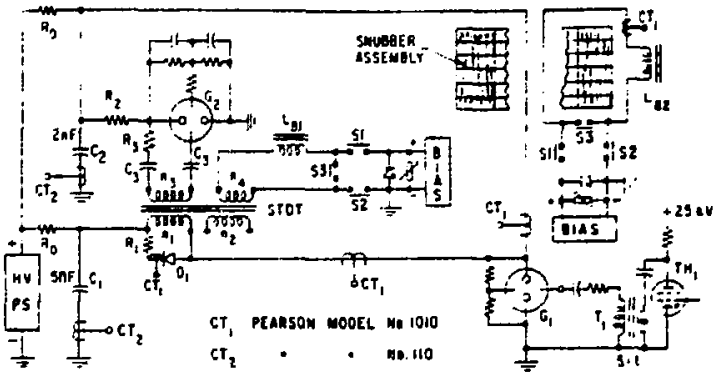

Fig. 5. Test Circuit.

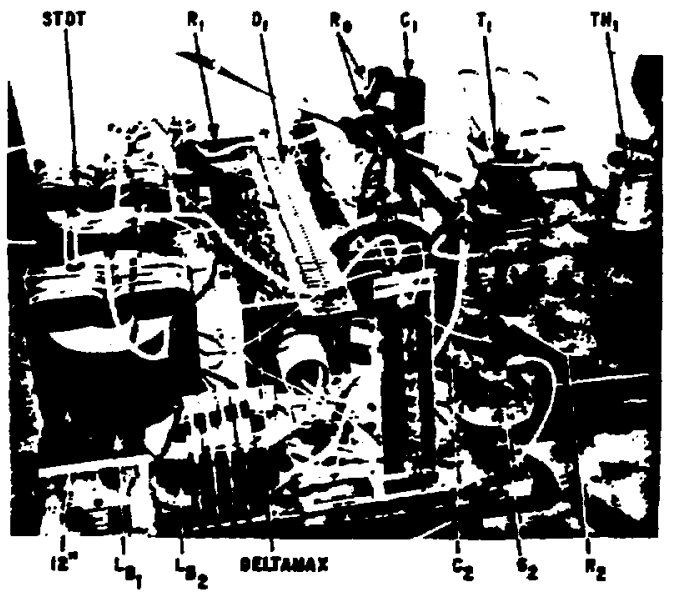

FIg. 6 Test Circuit Components.

Tests W1thout Spark Gap C2, WIth the STDT disconnected, the 2 nF capacitor $\mathrm{C}_{2}$ was discherged through the snubber whan spark gap $G$ we triegered vie throetron $\mathrm{TH}_{1}$. The triger pulee to thyretron $\mathrm{TH}_{1}$ wa also used to trigrer the time swep of the oscliloscope used to monftor the output of the current tranaforwers (CT's). The apark gap, especielly at low voltages, does not elmye breal over at the same time after $\mathrm{Th}_{7}$ Is tricgered. This tim jitter ceuses the tilue delay seen in som of the pictures at the stert of the discharge pulses. By weene of switchas $S_{1}, S_{2}$, and $s_{3}$, the effect of bias clrcult parareters wes Investigated.

A discherge from $70 \mathrm{kV}(4.9 \mathrm{~J})$ with all switches open, efter the snubber cores had been reset, is shom in Fige. 7e. The "NBS" fault current is mespred by CT. The capecitor current 1a mesured by $\mathrm{CT}_{2}$. Ciosing sitch $S_{3}$ after the core had been reset resulted in current pulses as shom in F18. Tb; the ic of the blas circuft ringe at $3.3 \mathrm{yz}$. Future opersting conditions are sinuleted by cloulne swlch $S_{3}$ after sore reaet and comecting the bins wisting to the primary winding. These conditiond are shown in Fig. 7c. With $84 \mathrm{kV}$ on $C_{2}$ we expect a penk current of 214 A. As show in 


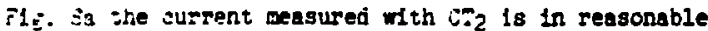
areement: this plcture ras saken with 111 switches zeen aiter the core had been reset. Figure $3 b$ ras -aken "ilth $\Sigma_{1}$ and $\Sigma_{2}$ slosed. The durrent througin the Enunded jiss írcuit. osclilating at $5.6 \mathrm{ktiz}$, is Euperimposed to the surrent show in Fif. Is. The surcen: irouch the ilas alreult is show in Fig. 3c. The inances in surrent shape and mapaltude ior various iaveis of energy are illustrated in Fis. 9, which sinows the 11 sciarge of a $7 \mathrm{nF}$ capact tor charged to 30 . co. and $35 \mathrm{kV}$.
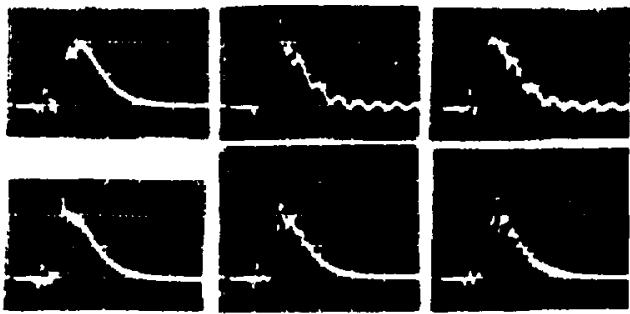

(a) $100 \mathrm{~A} / \mathrm{dIV}$ (b) $0.5 \mathrm{us} / \mathrm{div}$ (c)

Fig. 7. Jischarges of $2 \mathrm{gF}$ at $70 \mathrm{kV}$.

(a)

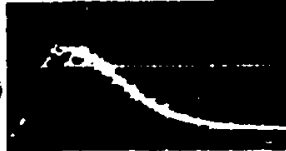

(b)

(c)

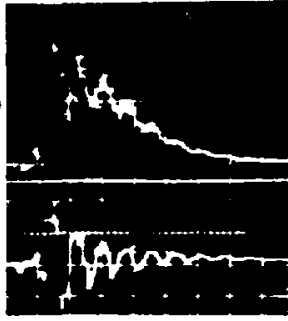

$100 \mathrm{~A} / \mathrm{d} 1 \mathrm{v}, \quad 200 \mathrm{~ns} / \mathrm{dIV}$

FIE. 3. Dischneges of $2 \mathrm{nF}$ at $84 \mathrm{kV}$.

Tests with Snubber and Soerk cap. For rererence, F1g. 10h bhow the mubber cliretet in of disconnected. 'It th the circult of Fig. 5, Fealetor $\mathrm{R}_{2}$ is perillel with the snubber when $G_{2}$ in triscured bs the STDT. in 11luetrated by F1g. 100, this hapened approximetely 170 as arter $\mathrm{C}_{2}$ begen to diechre. The capacitor current is sboin in F1e. 100; it sbows the currunt step when $G_{x}$ turns on. The pletures in Fis. II 11lustrete hor the time to trieger $\mathrm{O}_{2}$ from the STDT decreasen es the opereting rolting increvess. This is also shown in Table III.

\section{Table III: Voltere and Trefer Deler of $G_{2}$ Fth 40 par or $\mathrm{N}$.}

$\begin{array}{rrrrrc}E_{0} & 60 & 70 & 75 & 84 & 10 \\ \text { st } & 360 & 170 & 120 & 100 & \times 10^{-9} \text {. }\end{array}$
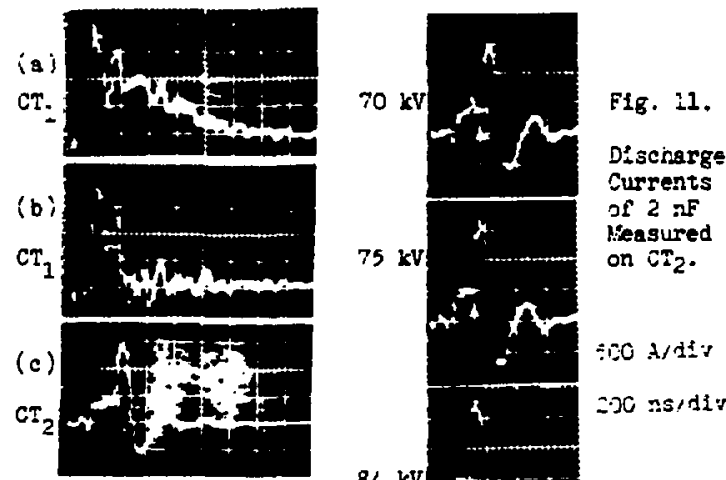

$\mathrm{CT}_{2} 500 \mathrm{~A} / \mathrm{d} 1 \mathrm{~V}$

$\mathrm{CT}_{1} 100 \mathrm{f} / \mathrm{dIv}, 200 \mathrm{~ns} / \mathrm{dIv}$

Fig. 10. Discharges of $2 \mathrm{IF}$ at $70 \mathrm{kV}$.

\section{The STDT Design}

In contrest to a snubber, an STDT ifmits faul: currents with its magnetfifing inductance. Eddy-current losses, utilized by a snubber, are undesfrable in an STDT. An STDT can be designed to provide time delays of tens of microseconds or longer, which is lmpractscal for a snubber. An equivaient cfrcult for the STIT portion of the clrcult of Fig. I 18 shom in FIg. 12. In this circult, It 18 assumed that the ST has arced over and that 4 us wlll elapse before the crowbar removes the power source. For simplicity, only the primary anding to the accel. $\operatorname{grld}\left(n_{1}\right)$ and the secondery winding of the blas current $\left(n_{4}\right)$ of the clrcult in Fig. 1 are being show. All primed components reprasent circutt values of the secondary of the SIDT tranaformed to the primary.
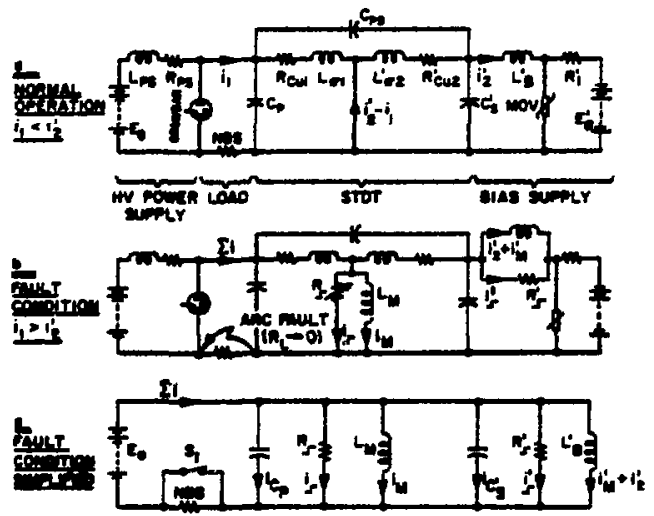

F18. 12. Iquivelent efreufte for an STDT.

Durtag norwal oporntion, the bles eurrent $I_{2}^{\prime}$ is targer then the land current $I_{I}$; thl seturetes the core (ude ${ }^{2} 200$ ). The power-eupply voltage eppensy acrose the loed. When the IBS aparies to cround, the SIDT cams out of seturetion and mentizing Impedence Iy and the ddy current resistance $R$ appeer in the cIrcult; $f^{\prime}$ eppener in the bles chole clrcuit. Voltag- $E_{0}$ 1. Iow ebworbed by the STDT. The copper losen and the lealoge induotences of the STDT are soull when capared wth $R_{\text {, }}$ and $I y$ and can, therefore, be noglected. This riculte In the simplified circut of 
F!3. $: 2$. The VRS is exposed to the sum or the cur-

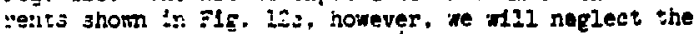

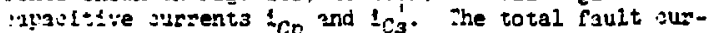
"ei: : van naw je ritiér.

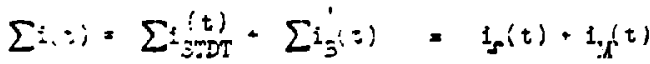

$$
\begin{aligned}
& +i_{z}^{\prime}+i_{2}^{\prime}(t)+i_{i n}^{\prime}(t),
\end{aligned}
$$

Zessuse $a a^{\prime}$ ine sparic gap clrcult, there is one more sieg-current cor the STDT show in F1e. 1 . Th1s curren: I $n$ must be added to the above surrents. Under wors:- falul condltions, $150 \mathrm{kV}$ all be applied to the sireylt. :He a1ll now eaiculate the fault current for -inis sase.

\section{Faul: Current $\left.\sum 1(t)=\sum i s c t\right)$. Table IV} glies jetelis of the STDTT 5 uflt for the clrcult shom in Fig. 2 .

\section{Teble IV: Detalls for 150-kV STDT}

Four sllectron cores AL-1268 with d $=5.08 \times 10^{-3} \mathrm{~cm}$

No. or Iamination $N=4 \mathrm{bg} / \mathrm{d} \quad \mathrm{N}=3560$

ISth ot Iaminations

w $=8.89 \mathrm{~cm}$

:io. of primary turns

$n_{1}=28$

No. of secondary tums

Volts/turn

$n_{2}=n_{3}=28, n_{4}=14$

$5357 \mathrm{~V}$

Volts/Lamination

$1.5 \mathrm{~V}$

Voltage gradient on laninations

$\xi=0.085 \mathrm{~V} / \mathrm{cm}$

Fength of flux path in iron

Jength of flux peth in elr gep

$2_{\mathrm{Fe}}=98.6 \mathrm{~cm}$

$c_{B}=5 \times 10^{-3} \mathrm{~cm}$

Core grea

A. $160 \mathrm{~cm}^{2}$

NBS operat1ng current

$f_{1}=65 \mathrm{~A}$

Fegic blas current for 5 de

$1_{B}=163 \mathrm{~A}$

aus blas current for 5 oe,

$$
1_{B} \sqrt{0.133} \quad=39.4 \mathrm{~A}
$$

From Eq. (11) and date of Table IV, the intinal current step is $1_{s}=15.2 A$ wen the lBS sparier donel I short tine later, current gtep $1_{\text {rc }}^{\prime}$ ocoure wem oner gap $G$ triggers. With $n_{1}=a_{3}$, thil current follow the excression

$1_{r d}^{\prime}(t)=\frac{E_{0}}{K_{3}} \exp \left(-2 t / R_{3} C_{3}\right)=60 \wedge \exp (-t / 0.2 \mu)$.

The manetizing current $i_{1}$ is celculated from the pul we mopnetization curvof of the core entexiel.? In our case whe heve, efter at $=4 \mu t$, e Nux change of

$$
\Delta B=\frac{\Delta t \times V 10^{8}}{n_{1} \mathrm{~A}}=\frac{4 \mu \times 150 \mathrm{kV} \times 10^{8}}{28 \times 160 \mathrm{~cm}^{2}}=13.4 \mathrm{kO}
$$

which is less then helf of the $30 \mathrm{~kg}$ avallable from,

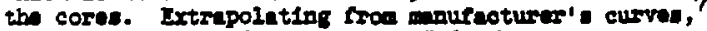

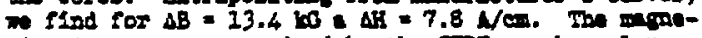
tization current required by the SIDT can be celculated from

$$
1_{1.1}=\left(\Delta H_{\mathrm{Fe}} \leq R_{\mathrm{Fe}}+\frac{\Delta \mathrm{B}}{\mathrm{S.4T} \tau_{5}}\right)^{/ \mathrm{I}_{2}}
$$

as

$$
i_{\mu}=\left(7.3 \times 98.6+\frac{13<00}{0.6 \pi} \times 0.005\right) / 28=29.4 \mathrm{~A} .
$$

Fault current $\sum f^{\prime}=(t)$. For the STDT to cope out oi setiration, the laul current must exceed the blas current $1 \dot{2}$. Transformed to the primary, the jlas surrent is

$$
I_{2}^{\prime}=1_{2} n_{4} / n_{1}=163 \mathrm{~A}: 4 / 28=81.5 \mathrm{~A} .
$$

Currents $f_{r}^{\prime}(t)$ and $f_{y}^{\prime}(t)$ are determined by the step roltage across the bias choike, winteh is

$V_{B}=E_{0} n_{4} / n_{1}=150 \mathrm{kV} 14 / 28=75 \mathrm{kV}$, and by the choke parameters given in Tajle $V$.

Table V: Detalls for the 75-kV BLas Choke $L_{51}$

Four Silectron cores Wth the dimensions of the $A L-1266$ cores

but wound with tape of

thickness

$d=10.26 \times 10^{-3} \mathrm{~cm}$

No. of laminations

$\mathrm{N}=1800$

Core Area

$A=162 \mathrm{~cm}^{2}$

No. of turns

$n=78$

Volts/turn

$961 \mathrm{~V}$

Volts/lemination

$0.53 \mathrm{~V}$

Voltage cradlent an

Iaminations

$\xi=0.030 \mathrm{~V} / \mathrm{cm}$

Length of als gep

$\ell_{\mathrm{g}}=1.7 \mathrm{~cm}$

DC magnet1zation

$\mathrm{B}_{\mathrm{dc}}=8.8 \mathrm{kG}$

The initial current step from $\mathrm{Eq}$. (11) is Is $=3.25 \mathrm{~A}$, whlch, transformed to the primery amounts to $1:=0.51_{s}=1.63 \mathrm{~A}$. Durlag the fault duration of $\Delta t=4 \mu \mathrm{a}$, the change in induction in the choire is

$$
\Delta B=\frac{445 \times 75 \mathrm{kV} \times 10^{8}}{78 \times 162 \mathrm{~cm}}=2.37 \mathrm{kG}
$$

Thls correoponds to $\Delta H=1.43 \mathrm{~N} / \mathrm{cm}$. The mentization current for $l_{\mathrm{F}}=98.6 \mathrm{~cm}$ and $l_{g}-1.7 \mathrm{~cm}$ is, from Eq. $(28), 1_{y}=42,9 A$. This value traneformed to the primery becones $1_{u}=0.51_{u}=21.4 \Lambda$.

Mrimun Velues of Fault Current. The etep currents

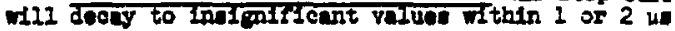
wile the wepnetiaing curreats, otarting srom zoro,

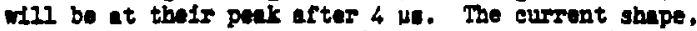
therefore, has tro pecien. One occurs at the time the NBS oparke to round. Its value of

$$
\hat{1}_{t=0+}=i_{2}^{\prime}+1_{s}+i_{s}^{\prime}+1_{s 0}^{\prime},
$$

1. In our case

$$
i_{t=0^{+}}=81.5+15.2+1.6+60=158 A .
$$

The second peek occure at the time rinen the fil source 1s crowburred. Its vilue of 


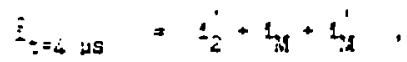

is : $: 2 r$ sur 20 plication

$$
i_{:=\text {us }}=21.5+29.4+21.4=132.3 \mathrm{~A} \text {. }
$$

$\because 1:$. ine iv source renoved. The magnetizing currents

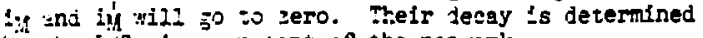
oj ise :, R :fre zonstant of the network.

The joove rorst conditions of $: 50 \mathrm{kV}$, when the 3: EFarks jver. should not occur often. Normally, then the :IES sparks down, only $120 \mathrm{kV}$ is applied for 2 us. Af:er :hat :Ine, the $S T$ ilsconnec:s the $H V$ source from $\because$. The jgcillatory Alscharge current of $C_{1}$ is ilmited by the magnetiaing inductance of the STDT as described abeve. Then $C_{1}$ has discharged, the circult ersergy is stored in the SnDT and In the blas choke $I_{g 1}$. Diode $D_{1}$ prevents $C_{1}$ from taking a negative charge and cuts off the fault surrent through the NBS. The inductively stcrec energies are dissipated in $\mathrm{R}_{1}$ and $\mathrm{R}_{\mathrm{Bl}}$.

Test iesults. In the clrcult of F1g. 5, capac1tor C. 13 discharged by triggering spark gap $G_{7}$. DurIne shose rests we and $R_{1}=20 \Omega, R_{3}=1 \mathrm{lon}$, and $C_{3}=$ $350 \mathrm{gF}$. As show in F1g. 13a, a surrent of about $11.5 \mathrm{~A}$ IlCWs for $26 \mathrm{\mu s}$; this amounts to $300 \mu \mathrm{Aa}$ whloh agrees with the charge on $\mathrm{C}_{1}$ of $60 \mathrm{kV} \times 5 \mathrm{nF}=300$ wa. The sAme sgreesent is found in $\mathrm{F} 1 \mathrm{~g} .14$, where $\mathrm{C}_{1}$ is discanrged from $84 \mathrm{kV} ; 34 \mathrm{kV}$ × $5 \mathrm{nF}$; $15.6 \mathrm{~A} \times 27 \mathrm{hs}=$ 420 wAs. The currents of 11.5 and 15.6 A are propor ional to the voltages of 60 and $84 \mathrm{kV}$. $\left[1-\mathrm{E}_{0}(\mathrm{C} / \mathrm{L}) \mathrm{l}\right]$. Figures $13 \mathrm{c}$ and $\mathrm{d}$ show the clrculating curreit through diode $D_{1}$, which discharges the STDT in $800 \mathrm{us.} \mathrm{At}$ $60 \mathrm{iV}$, the initial current opike of $\hat{1} \cdot 15+1 s \mathrm{~s}$. expected to be $1 \approx 15.2 \mathrm{~A}(60 / 130)+60 \mathrm{kV} / 1 \mathrm{kn}=$ $69.6 \mathrm{~A}$. Flgure $13 \mathrm{~b}$ shows an oscillatory peak of $190 \mathrm{~A}$. These iarge infilal oncillation last for about $500 \mathrm{ne}$ and are attributed to the capecitence betwen ofindinge $n_{1}$ and $n_{4}$. With $n_{4}$ grounded, the laterindine capac1tance $1 s^{6}$ charged to $60 \mathrm{kV}$ and discharges Wth 11ttle series inductence then of in triggered. In the ITIR clrcult (F1E. 1), both nI and $\mathrm{D}_{4}$ are at the same potential when the NBS sparks dom; this should eliminate the Initial large oscilletions.

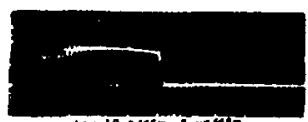

(e) 10 vadt, s watr

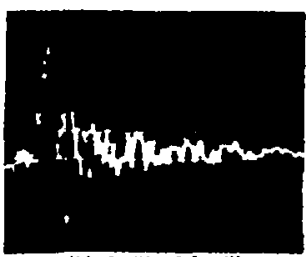

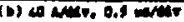

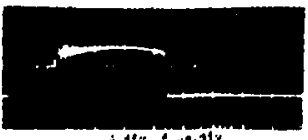

F18. 14 .

Disohare of $5 \mathrm{nF}$ at $84 \mathrm{kV}$.

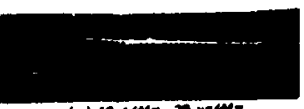

(o) 10 wase, 20 sarms

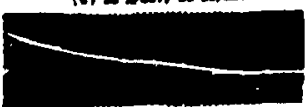

(a) 10 Matv, 200 molat

F1. 13.

Discharge of $5 \mathrm{nF}$ at $60 \mathrm{kV}$.

STDI's For the LFe and F12ament Clrcuste. The filenents of the hiss opernte at 6 k. Wha duty factor of 0.133 , the ourrent in $2.2 \mathrm{ld}$. For the are supply, the pack curreat is $3 \mathrm{kh}$, the duty factor 0.033 , and the sus curreat $545 \mathrm{~A}$. It appears to be more economical ana more rellatie :o replace the Jeltamax snubber and the spsrk-zap otroult of F1g. I : 1 th tro STDT' 3,33 shown in FIg. 2 . :Ie gre presently investigaing this posstbility. Data for a prelloinary Jesien Sor STDT2 are given in :3ole "I.

\section{Table UI: Details for the i20-iV ETDT2}

io Sflectron cores AL-1i45 $\mathrm{rizh} d=5.02 \times: 0^{-3} \mathrm{dm}$

No. of iamingitions

$N=15,000$

iVIdich of laminations

$N=6.99 \mathrm{~cm}$

No. of bifliar turns

$n=4$

Volts per turn

$30 \mathrm{sV}$

Volts per lamination

$2.0 \mathrm{~V}$

Length of flux path in fron

Length of rlux path in 315

Core ares $10 \times 0.28 \times 6.45 \times$ 0.89

$1=\mathrm{nA} \Delta \mathrm{B} \times 20^{-8}$

$2_{\mathrm{Fe}}=121.4 \mathrm{\textrm {m }}$

$R_{g}=5 \times 10^{-3} \mathrm{~cm}$

Infilal current step

$A=573 \mathrm{~cm}^{2}$

$=0.69 \mathrm{Vs}$

1s $=170 \mathrm{~A}$

Co1l realstance

$\approx 102 \mu \Omega$

Heat dissipation

$\approx 500$ \%

Cost of core material

$\$ 5730$

$+$

For the arc leads and the coaxial monitoring cablos, anotber smeller core assembiy is vlounlized for STDT 3.

\section{REFERENCES}

1. w. F. Praeg, "A intureted Time-Delay Transformer for Overcurrent istection of DC Acceleretors," ANL/CTR/M-59, Aide ine National Laboretory, Argonne, IL (December 1975).

2. W. F. Preeg, "Saturating Tine-Delay Trantormar for Overourrent Protection," U. S. Patent Ho. 4,054,933, October 18, 1977. Flled December 18, 1975 .

3. W. R. Baker, "Stored Eneres and the IBL Neutral Baam Source," Inwrence Berkeloy Laboratory, Internel Vino UCID-3871 (Kay 1976).

4. w. F. Preeg, "Protection of Weutral-Beam Accelerator Electrodes From Spark D1scharges," ProceedIngs of the 7th Syupostum on Endrenreing Problems of Fuslon Research, Det. 25-28, 2977, Knoxv1lle, Tw.

5. W. R. Burer ot al, "120 kif/65 A Neutrel Bear Souree Spectelcettou and Mectricel Requiremanta," Larrence Barkeley Iaboratory, UCID-8069 (0et. 1978).

6. S. T. Winter, R. W. Kunning, G. G. Berg, "Pulse Properties of Large 50-50 NI Fe Tepe Corea," IEEE Treneaction on monetice, Vol. Ma $-6, N o .1$, (1arch 1970).

7. The Arrold Bngtneering Co. publicetion TC-1018 "Tape Wound cores." 


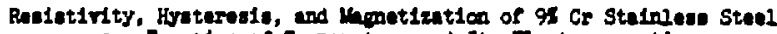

10 a Punction of Tepernture and Ite nectrompretic

shieldine Erfoote in Gilindricel stmictures"

w. F. Preng

Irgonne Mutional Inboratory

Argonne, Il 60439

Sum

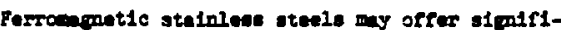
cuntlo creater well life-time for f1ret muldolankt and reculin reasel atructuren then cosinonly ued non-

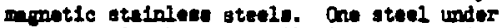
consideration bae the following colposition, in walght pareent,

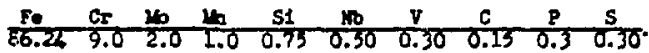

There appeare to be no Ifterature on the electronenetic propertien of this meterlal. Therefore, the renistivity. the braterealo loopa, and nemetization wre nearured as a fretise of temperature up to the curle polnt.

For Tolnank application it is of specific intervat to hoor the reafotivity and aturation Rux deanty in the renge tros 400 to 60000 . By epplying a toroidal f1eld that saturates the forromanotic oteel, the flrat mildolenket and verum veseal strictures obould

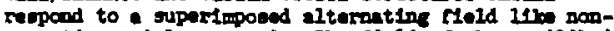

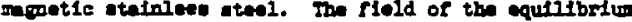

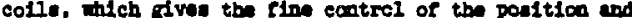
obape of the plese, sut peatrate the efrest wII/ blenkat and/or vecuim reasel. Hormiled maph are

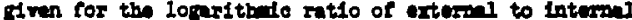
clternating slolas (ahtelding) is a rumotion of the ratio of wil thickeses to itin depth, wth vases?

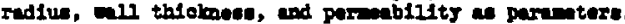
These exeph abould be uneful for the denten of reed-

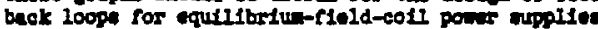
and in the dealonin of electromonatio ahlolde wth this enteriel, alther do entureted or not.

\section{Baelativity}

$300 \mathrm{~cm}$ lane wire casole we dras to dienter of 0.159 on and aneeled at $11000 \mathrm{C}$ for bilf an bour.

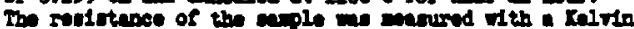

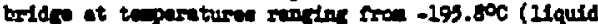

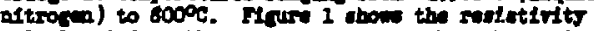

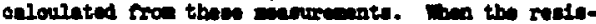
tirits an celouinted, no correotion wre mote to socount for the effecte of the coeffloient of tharmil

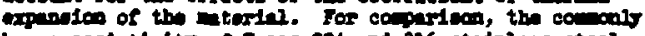

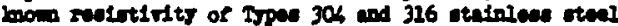
1s alco ahom.

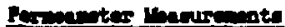

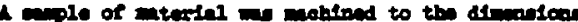
$7.232 \times 1.232 \times 2.540 \mathrm{~cm}$, ad the B-1 curvec stom in

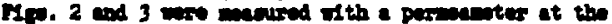

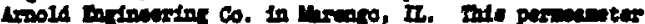

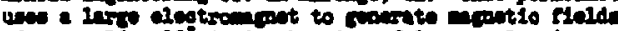
of up to $16 \times 10^{\circ}$ on in the t1pe of ince pole pieces

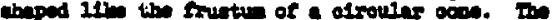
diftanos betinem the pole pleane is adfuntable to

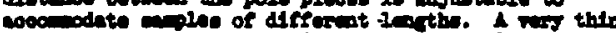

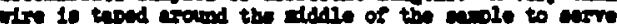

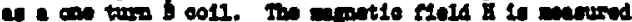

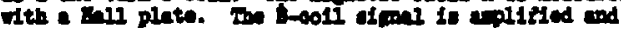
intaprated and uned for the vertion doflestica of a

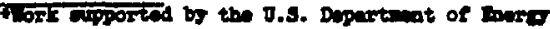

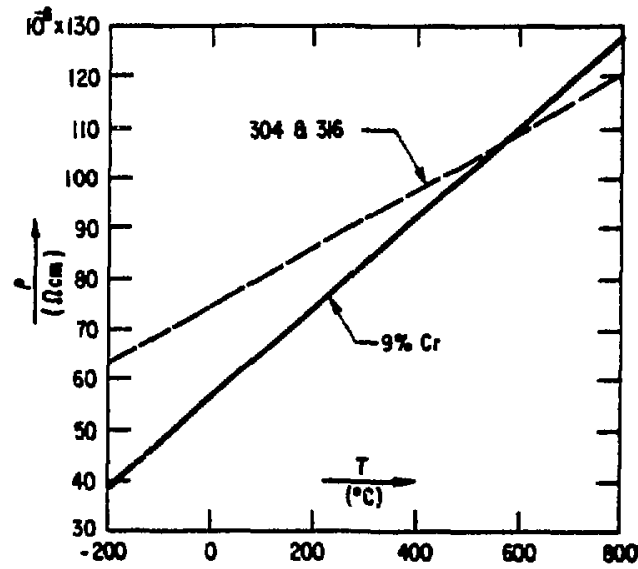

Moure 1 Mectricel Ranlotivito in Stafnlone Stalo

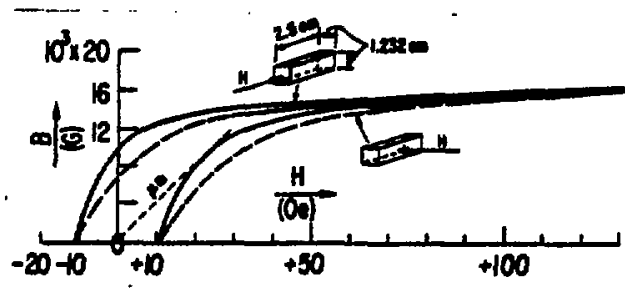

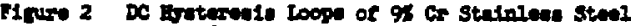
sapio for $\mathrm{B} \leq 130$ or

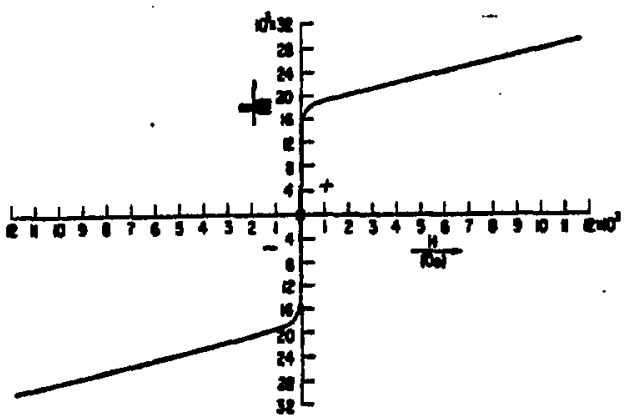

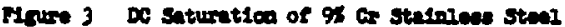




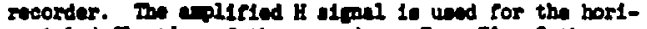
sontel deflection of the resorder. Frod Fic. 2 the

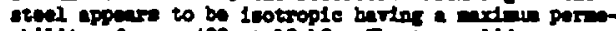
ablilts of $u=400$ at $10 \mathrm{~kg}$. The two solld eurres

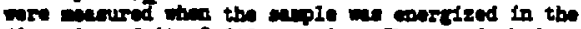
diretetlon of its 2.540 en axds. The tho daubed curves

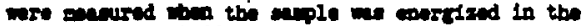
direction of 1.232 en axis. In the perreantor the ret1o of the learth of the als gap latr to the length

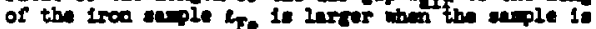

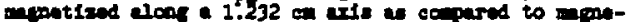

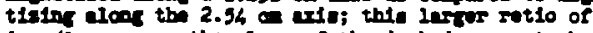
latf/ife culese the slope of the deshed curve to be Ale as oc pared to the lope of the colld curve. Fron Fice. 2 and 3 w we thet the steel saturates et roce teporsture at $\leq 20 \mathrm{bl}$.

\section{Mequrente an Toroldel saple}

\section{Saple Proparation}

a toroldel seplo an mohtined to en outalde

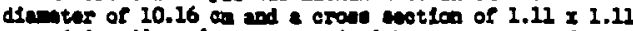

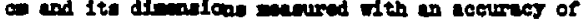

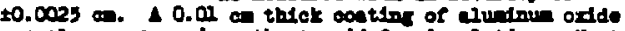
1. plen-oprajed on the torold for inoulation. MeIt

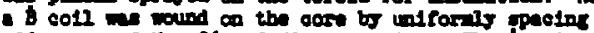
103 turas of Ho. 26 Ano Nlobran wire. The 80011 me

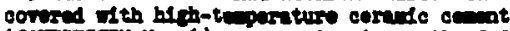

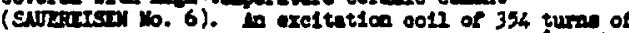
bare Ho. 18 ins sopper wre wo woud orer the 10011

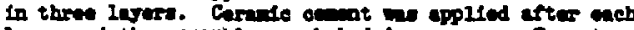

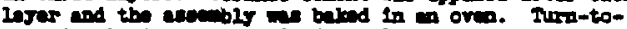
turs inculation ane provided bs plecing a ciese-querts.

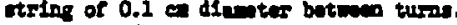

\section{venuren cireuste}

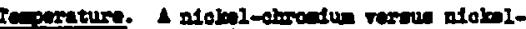

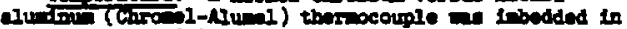
- Eell bole drilled 2.5 en depp lnto a plece of eteel

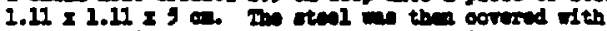
the ane thelories of conat en the torold and pleced in the one rext to the torold. In ere thato corplen wer pleced in the enater of the torold.

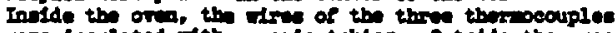

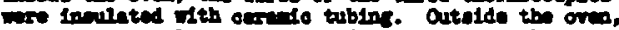

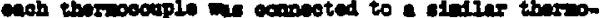
couplo in exites oppontion. In this ing the

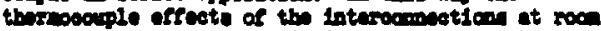

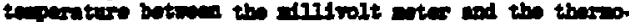

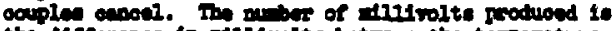

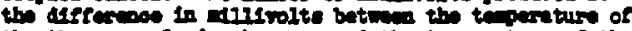

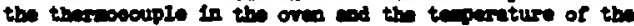
tharsecuple on the outelde. The thres outnide tharmi-

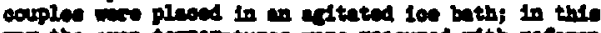

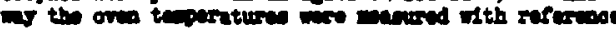

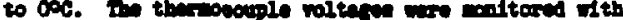

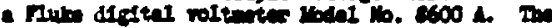

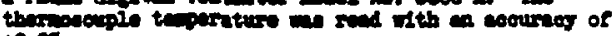
\pm 0.25 .

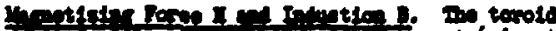

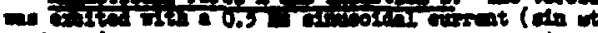

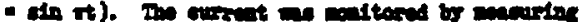

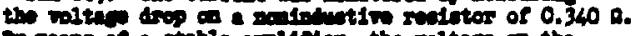

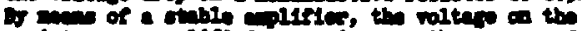

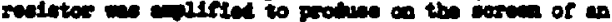

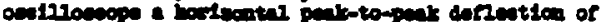

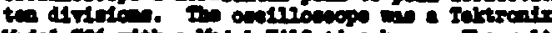

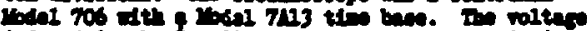

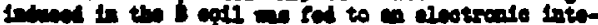

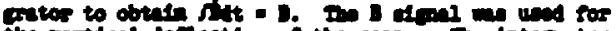

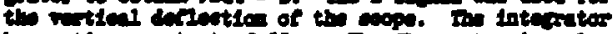

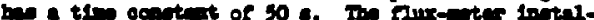

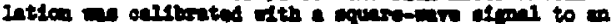
nowusey of $2 x$.

\section{Genurenente}

Hyaterenle Loops. A monatization ourre (nolld)

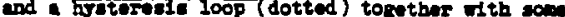
1uportant menotle quantities are show for dorinltion In Fig. 4. Figure 5 show a fere of the byaterenls loope masured. In theae pletures, tho areftation is hold conetant at $\mathrm{H}$. $H_{0}$ ofn ut $=35$ sin $\pi t \quad 0$ and the temperature $I$ is changed. The orea bes a repulator that bolda tecperature whits a rew decrees of a sot point.

It took approximtely two houre at a set point to reech a stable tefperature in the torold. The seneitivits of the B seale we locreased to take moesureneste near the Curle point; this 10 1liustrated by Fic. 6 . The result of the neworesents are oumerized in F1ge. 7 and 8 . Retoming to F18. 7, the Curlo polot of the anple is et $709^{\circ} \mathrm{C} \pm 4^{\circ} \mathrm{C}$. It mertain permablitts it $=675$ is reached around $400^{\circ} \mathrm{C}$. It $20^{\circ} \mathrm{C}$ on bave if 275 ; this 19 Jarger than the $t_{0}=400$ abom in Fis. 2. The differmen is the to the unavoldeble als gape when

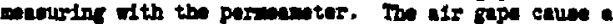
smeller olope (abearing) of the B-fl curve.

The conrelve fores, He, declines as the tepeneture incrances. It room tepereture the velue Enerrured

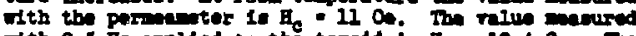
-ith 0.5 te epplied to the torold is $\mathrm{B}_{\mathrm{c}}=22.4 \mathrm{Oe}$. The differenos is due to en inorwes in edds-ourreat loseen

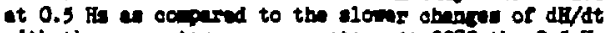

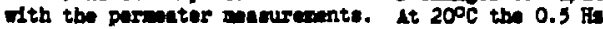
iden dopth

$$
\text { s. }\left(\frac{0}{\mu T T}\right)^{1 / 2}
$$

of the torold aterial it

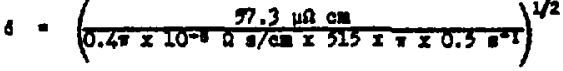

$$
\begin{aligned}
& \text { - } 2.37 \mathrm{~cm}
\end{aligned}
$$

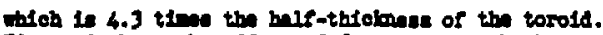

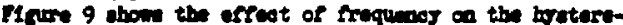
als $100 \mathrm{p}$ of the torold. At $20^{\circ} \mathrm{C}(\mathrm{c}=2.37 \mathrm{as})$ the loop wddens noticenbly betwen 0.05 Ba ( do cale ) and 0.5 Hi. Fro Fie. 9 the de pernabilits cen be celou-

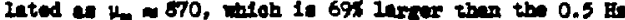

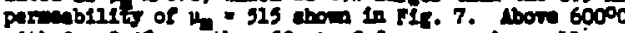

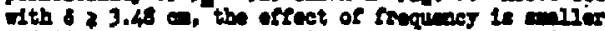
and dienprente en of olower to the cure point.

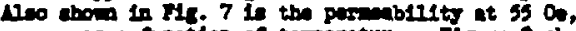

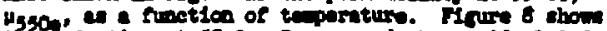

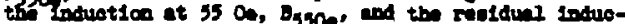

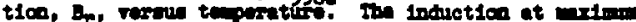

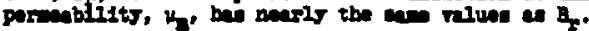

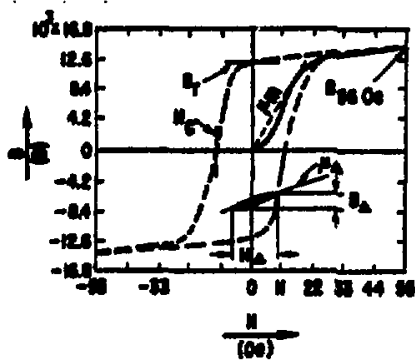

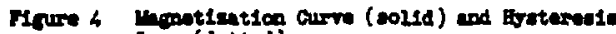
Loop (dotted) 


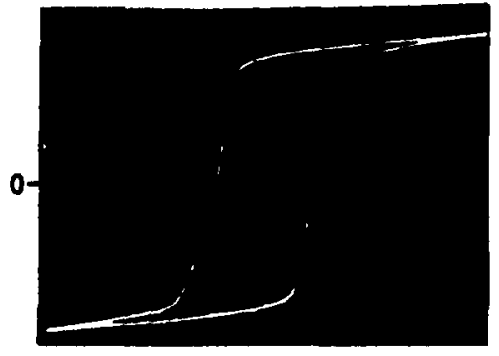

$20^{\circ} \mathrm{C}$

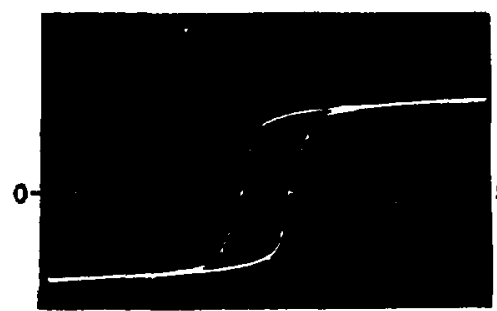

$5570 \mathrm{C}$

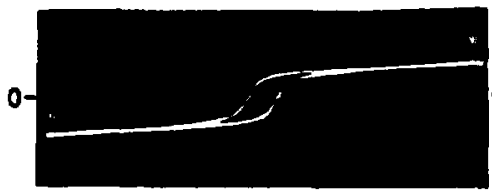

$603^{\circ} \mathrm{C}$

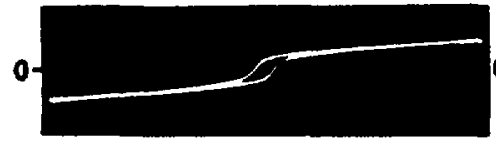

$69 \sec ^{\circ}$

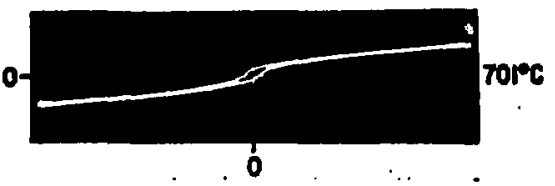

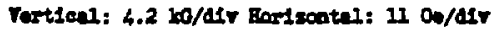

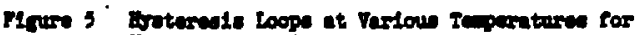
$\mathrm{I}=55$ ofln $\mathrm{rt}$ -

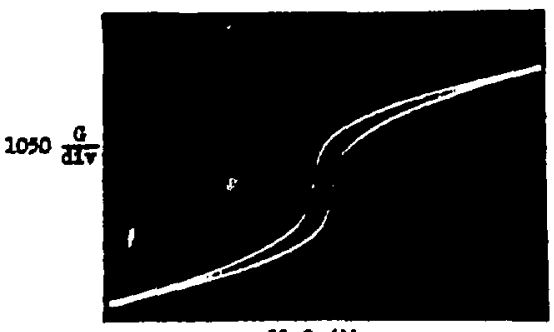

21 on/dtr

Houre 6 Hratervele toog at $696^{\circ} \mathrm{C}$

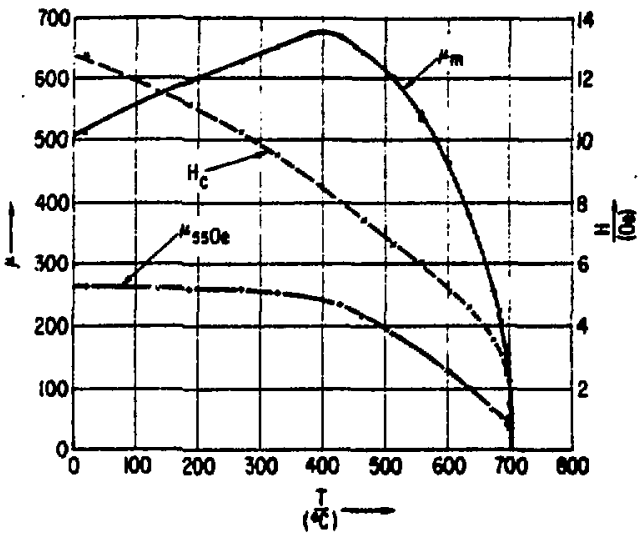

Ficure? Veriation of Permabillts and Cowre1ve Foree With Teipereture for A -55 ain wo

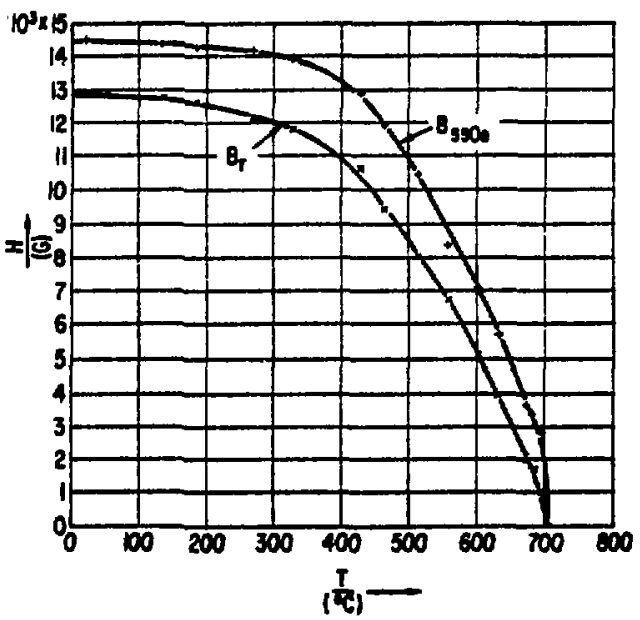

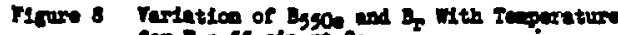
for 1 - 55 in in on

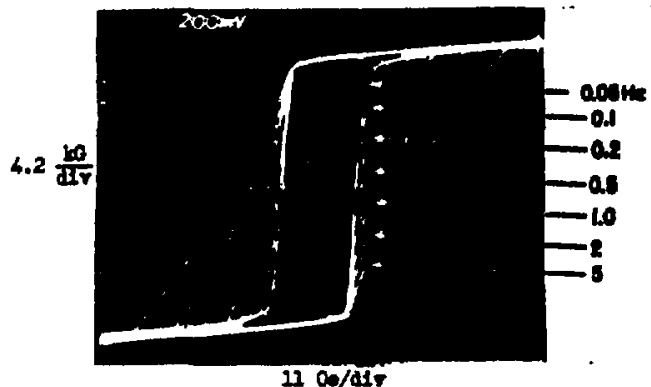

Mrore 9 Hyatervele Loope of Toxoldel seple for Vartlous Frequapios at $20^{\circ} \mathrm{C}$ 
Fontizet100. Japot1zation curves, sanoured at

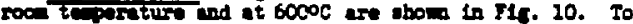

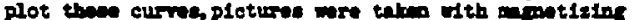
forees of $\mathrm{H} \geq 1$ on efter the torold had been deremetised by besting it above the curle polnt. Flcures 11 and 12 how coponiten of difforent brotereals loope

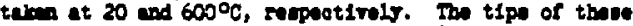
loope 110 on the reppetive nmotization curven.

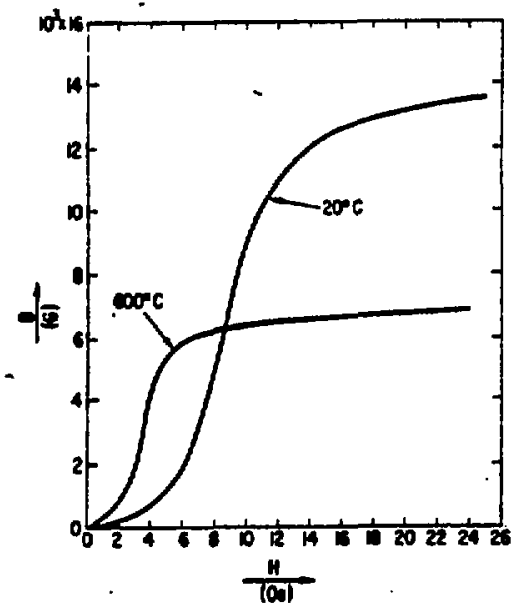

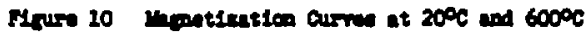

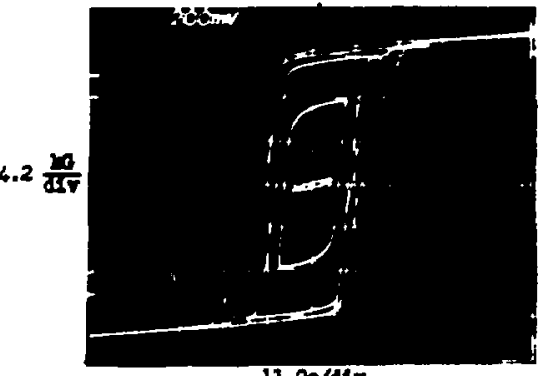

$1100 / d 4$

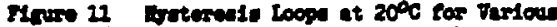
Mrentudes of Field strugth

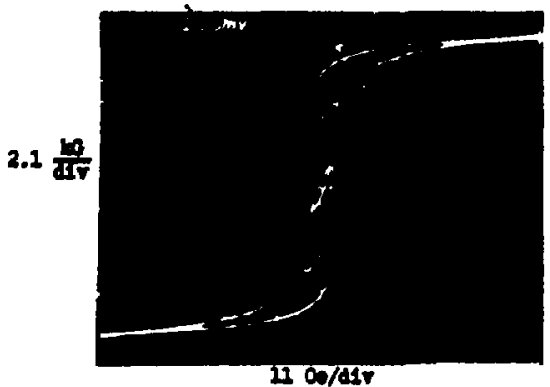

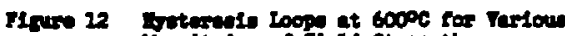
montrules of Hidd strwath

\section{Electronemet1e shlelding}

In Tomme the fleld of the equilibriue colle, wheh gives the sine control of the position and sbepe of the plesen, wat penotrate the efrat wil and/or the vecull veasel.

With the resiatirity, $\rho$, and the permebility, $u_{\text {, }}$

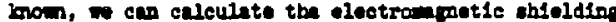
affact. of colindrical structures butit from $91 \mathrm{Cz}$ oteal. Tho conditiona are convidored. F1rat, the

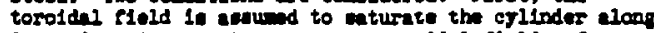
It: exis. At rooe tompreture, toroldel flolds of $\geq 20 \mathrm{bf}$ and at $500^{\circ} \mathrm{C}$ flelds of $\geq 16 \mathrm{bc}$ cospletel at aturete the ateel (ane Fige. 3 and 8 ). The equilibrius r1eld, which 1s trenveres to the axte of the cylinder.

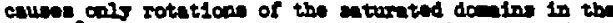

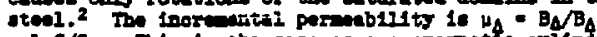

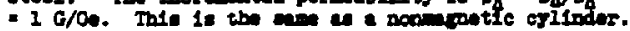

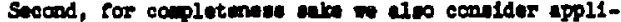
ontione in wieh the $9 \mathrm{Cr}$ oteel in uned uneturatiod as an electromentio oriledrieal ahield.

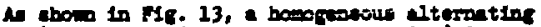
fleld $H_{0}$ (the rield of the equilibriu colla) is applind tremereres to the axis of the cylinder; the renultias electrio field $z$ is in the direstice of the orilindor exte $z$. The fleld inatde tho orlinder $\mathrm{H}_{1}$ cen be restite

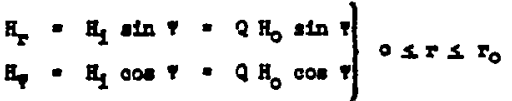

The teotor of electromontlo ablelding $a$ can be artent

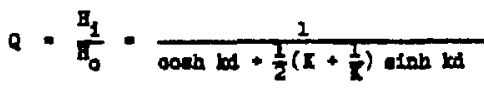

there

$x$ - ads oursent ocantent $=\frac{1+9}{6}$

$J \cdot(-1)^{1 / 2}$.

- adn depth $-\left(\frac{\rho}{\ln }\right)^{1 / 2}$,

$\mathbf{x} \frac{u_{0}}{\boldsymbol{n}} \mathbf{z} \boldsymbol{z}_{0}$

$u_{0}=0.4=10^{-0} \frac{\mathrm{H}}{\mathrm{o}}$ parmability of apece,

ad

4. parability.

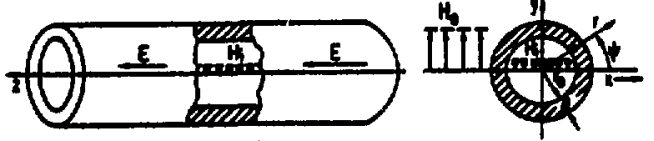

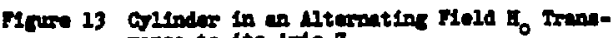
Gere to ste 2 
Noropotie Gilindes. Wth tho cylloder setureted

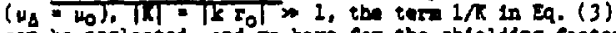
oes be neplested, and as have cor the shlelding factor

$$
2=\frac{1}{\cosh k d+\frac{1}{2} K \operatorname{aghh} k d}
$$

The attenuntion af of the cylleder is dorteed by

$$
\text { s - In } \frac{1}{\text { Tot }} \cdot \ln \left|\begin{array}{l}
n_{0} \\
a_{1}
\end{array}\right|
$$

Fros EqE. (3' and 4$),$ en obtuis

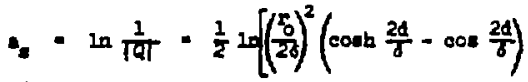

$$
\begin{aligned}
& +\frac{r_{o}}{2 d}\left(\operatorname{lng} \frac{2 d}{\delta}-=10 \frac{2 d}{\delta}\right) \\
& \text { - } \left.\frac{1}{2}\left(\cosh \frac{2 d}{\delta}+\infty \frac{2 d}{\delta}\right)\right] \text {. }
\end{aligned}
$$

Finure 14 abom the attenuatica, celculeted from Eq. (5), a runotion of $d / \delta$, whteh is proportional to the square root of the frequenes, for dffferent pera-

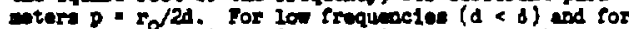

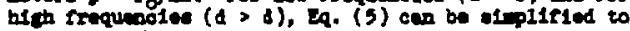

$$
\begin{aligned}
& \text { - - In } \frac{1}{\operatorname{lot}} \cdot \frac{1}{2} \ln \left[2+\left(\frac{x_{0} d}{b^{2}}\right)^{2}\right] \operatorname{sos} d<\theta \\
& \text { * - In } \frac{1}{\operatorname{lot}}-\frac{d}{6}+\ln \frac{s_{0}}{2 \sqrt{2}} \quad \text { for } d>c \text {. }
\end{aligned}
$$

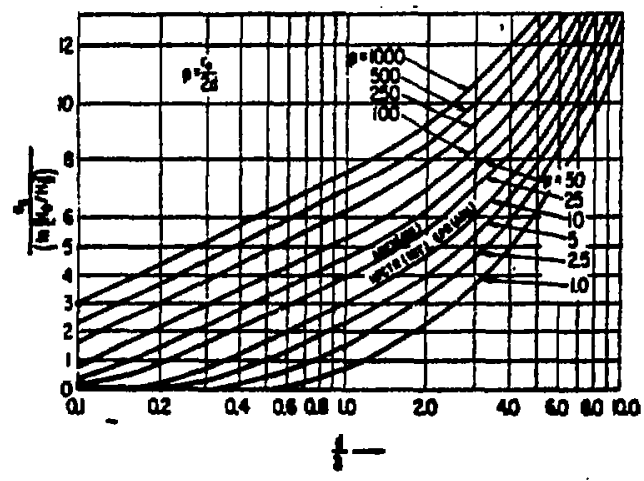

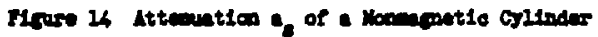

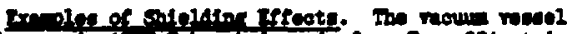

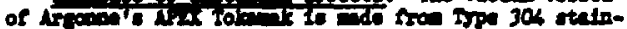

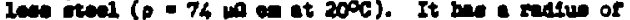

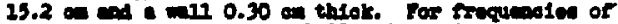

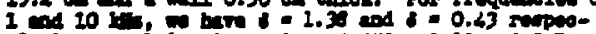

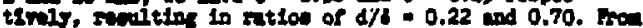

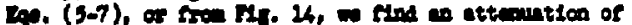

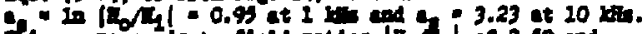

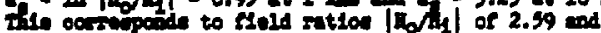
25.3 repent1615.
Artonne's IPR denien hat 7 on thet vacum vensel mide rron Type 316 stefnions steol. With on ererege radiue of $r_{0} \approx 220, m$ bave $p=F_{0} / 2 d-13.7$.

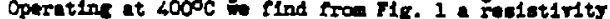
$0.98 \mu 9 \mathrm{ge}$. For frequenclen of 10 and $100 \mathrm{~Hz}$, w heve $d / \delta=0.644$ and 1.61 , respective1y. From $\mathrm{Eq}$. (5) or the curren of $\mathrm{Fle}$. $14 \mathrm{me}$ flad for $10 \mathrm{~Hz}$ en ettenu. ation $=$ In $\left|H_{0} / \mathrm{H}_{1}\right|=1.84$ and for $100 \mathrm{Ez},=4.26$. Thle correnponde to ration of $\left|\mathrm{H}_{\alpha} / \mathrm{H}_{1}\right|=6.3$ and 64 . Ierpectively. A total of 20 en of stalnlesestenl flret mil/sienket materiel is inside the recum nerael to oinfmlee radiation dawage to the veseel. If thts $20 \mathrm{~cm}$ thick meterial wre elso in the form of a vaeanl the conbined will thickrass would be $d \sim 27 \mathrm{~cm}$. For

Eraquencles of 10 and $100 \mathrm{~Hz}$ would have $d / 8=1.71$ and 3.42 , respetively. From $\mathrm{Eq}$. (7) the atterustion at $10 \mathrm{~Hz}$ would be .3 .31 and at $100 \mathrm{~Hz}, \mathrm{t},=8.17$. The sorresponde to retioe of $\left|\mathrm{H}_{\mathrm{O}} / \mathrm{AH}\right|+27.5$ and 3333 .

raspectivels. In order to xeduce eddj-current ahiolding

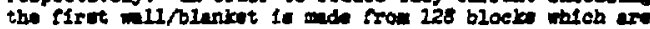
inoulated troe ench otber. Each block is ande troe $20 \mathrm{~cm}$ thick Type 316 stalnlese steel Hat plate.

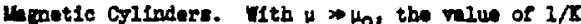
In Eq. (3) 1s larger thin 1 and can no lacerer be meelected. From Eq. ( 3 and 4 ), the cenerel equation for the attenuetion is given by 1

$$
\begin{aligned}
& \text { a. - In } \frac{1}{|Q|} \cdot \frac{2}{2} \ln \left[\left(\frac{\mu_{0} \Sigma_{0}}{2 \mu_{0}}\right)^{2}+\left(\frac{\mu_{0}}{\mu_{0}{ }^{2}}\right)^{2}\right] \\
& =\left(\cosh \frac{2 d}{\sigma}-\cos \frac{2 d}{\delta}\right)+\frac{\mu_{0} T_{0}}{2 \mu^{\sigma}}\left(\sinh \frac{2 d}{\sigma}-\operatorname{cis} \frac{2 d}{\delta}\right) \\
& +\frac{4 \delta}{4 H_{0} x_{0}}\left(\operatorname{tgnh} \frac{2 d}{\delta}+\sin \frac{2 d}{\delta}\right)+\frac{1}{2}\left(\cosh \frac{2 d}{\delta}+\cos \frac{2 d}{\delta}\right)(8)
\end{aligned}
$$

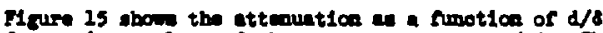
for virloue vilue of the perencter $p$ - uofolud. The differsas of theme curres as comparid to the currea of

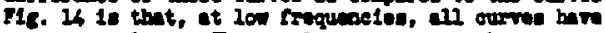

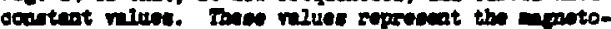
statio ahfeldin of the cylinders. It the lidt with

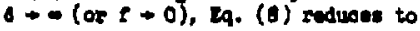

$$
\lim _{0 \rightarrow 0} \cdot \ln \left(2+\frac{1}{2} \frac{11 d}{u_{0} T_{0}}\right)
$$

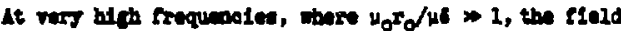
doen not peontrete the oylinder aproefinbly and monto-

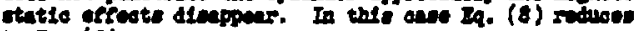
to Eq. (5).

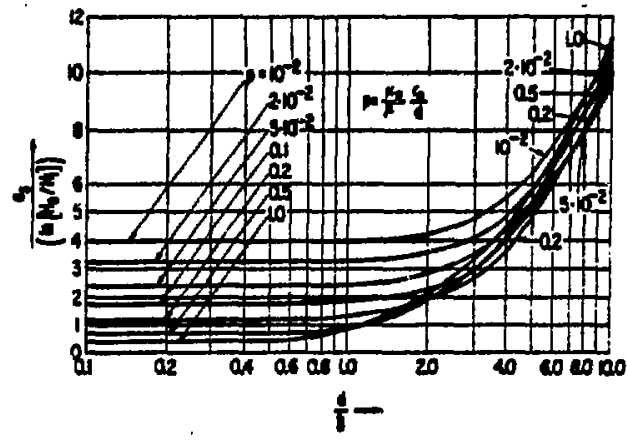

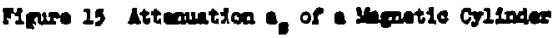




\section{Nomonled rament}

It 18 aleswar to comonledy the appart of Don rache wo deal aned and bullt the interetor and eplifler ofroulte and petiently took orex 100 oseliloscope plotures.

\section{Rererences}

1. A. Indea, "Wirbeletrone and Schirime in der Nebrichtentechnik." Springer-Verler, Barlin, 1959.

2. R. M. Bozorth, "Forromegnot1en, " D. Ven Hastrand Co. Ine., Now York, 1959 


\section{DEVELOPHENT OF A 50 KA CRYOSTABLE AC SUPERCONDUCTING CABLE*}

S. H. KII and S.-T. Wang

Argonne lactonal Laboratory

Argonne, Illinols 60439

\section{Summary}

A design of a $50 \mathrm{kA}$ cable at $8 \mathrm{~T}$ for superconducting ohalc heating cotls is presented. The cable, which will be cryostable with relatively low ac losses, is composed of 24 basic cablcs and stainless steel backbone. A non-metallic cryostat for the test of pancake coils of the cable is developed.

\section{Introduction}

The conceptual design studlea of toknsak reactors undertaleen at Argonne National Laboratory (ANL) and elsewhere over the past several years have identified the requirement of superconducting ohmic heating colls. The ohmlc heating colls will have stored energies of the order of $1 \mathrm{GJ}$ and a peak operating current of between 50 and $100 \mathrm{kA}$ with $d B / d t$ of approxinately $9 \mathrm{~T} / \mathrm{s}$. Because of the large stored energies, the colls should be cryogenically stable and still have tolerable low ac losses during the high ramping rate of the agnetic Iteld. Recently, ANL has developed a $11 \mathrm{kA}$ cable

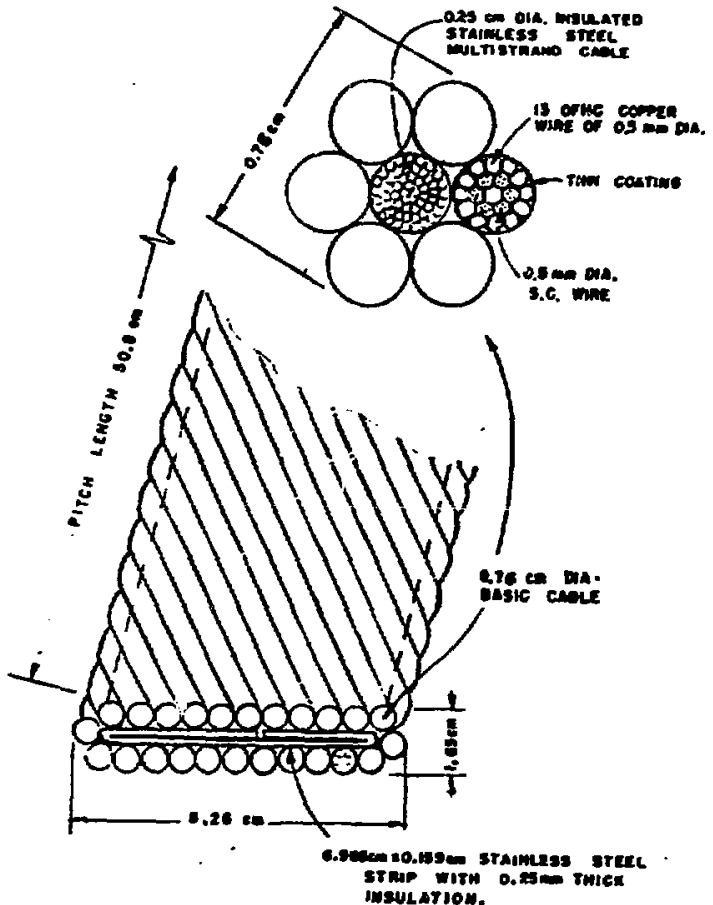

F1g. 1. So kh $M$ Superconducting Cable and its Baste Cable and dewonstrated the cryostability of the coll ande from the cable. $1,2,3$ The purpose of this paper is to describe a 50 kA cable. The design of the ceble is based on the design and test results of the $11 \mathrm{kh}$ cable.

\section{Design of the $50 \mathrm{kA}$ Cable}

The structure of the $50 \mathrm{kA}$ cable is ghown in Fig. The cable is assembled by twisting 24 basic cables around an Insulated stalniess steel or G-10 etrip with a tulsting pitch of $50.8 \mathrm{~cm}$. The cabling device will provide sufficient stranding tenston and pressure to assure a tightly packed cablc assembly having an effective cable cross section of $8.26 \mathrm{~cm}$ by $1.65 \mathrm{~cm}$.

The basic cable, shown in the upper part of Fig. 1 . is conposed of six 19-ulre cables by tulsting together around an insulated miti-strands stainless steel cable with a tulsting pltch of $2.5 \mathrm{~cm}$. The stainless steel cable is introduced to reinforce the tensile strength of the basic cable.

The 19-wire cable consists of three layers of wres with a copper wire at the zenter, six superconducting wires in the second layer and 12 copper wires Ia the outer layer. The lay of wires is as tight as the geometry allows with a twisting pitch of $0.8 \mathrm{~cm}$ for the second layer and $1.25 \mathrm{cr}$ for the outer layer. Then the 19-wite cable is soldered with Staybrite and the surface of the cable is weakly insulated by coating a thin organic film. The soldering and the weak insulation are intended to achleve both the cryostabilfty and relatively low ac losses of the cable in pulsed field.

\section{Cable Test}

The perforance of the $50 \mathrm{kA}$ cable will be teated intelally in a fora of pancake coils. For two pancake colls, ac losses at a central field rate of $9 \mathrm{~T} / \mathrm{s}$ are estimated to be approxfmately $5 \mathrm{~kW}$. In Table 1, parameters are 11sted for a $65 \mathrm{MJ}$ coll with 22 pancakes.

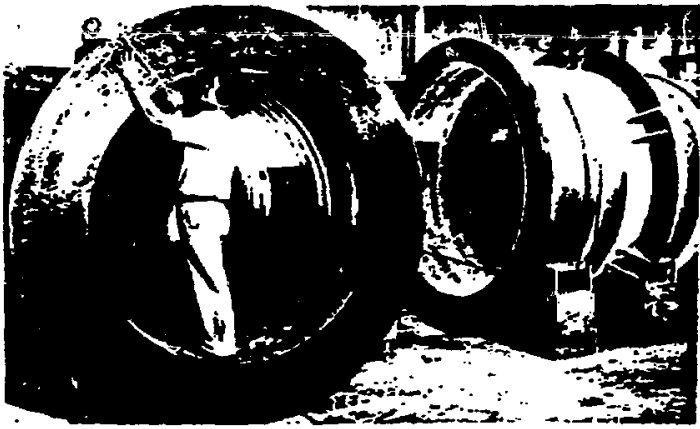

Fig. 2. Inner (Left) and Outer (Right) Tanks of the Son-Wetallic Cryostat

\footnotetext{
"Hork supported by the U.S. Depertment of Energy
} 


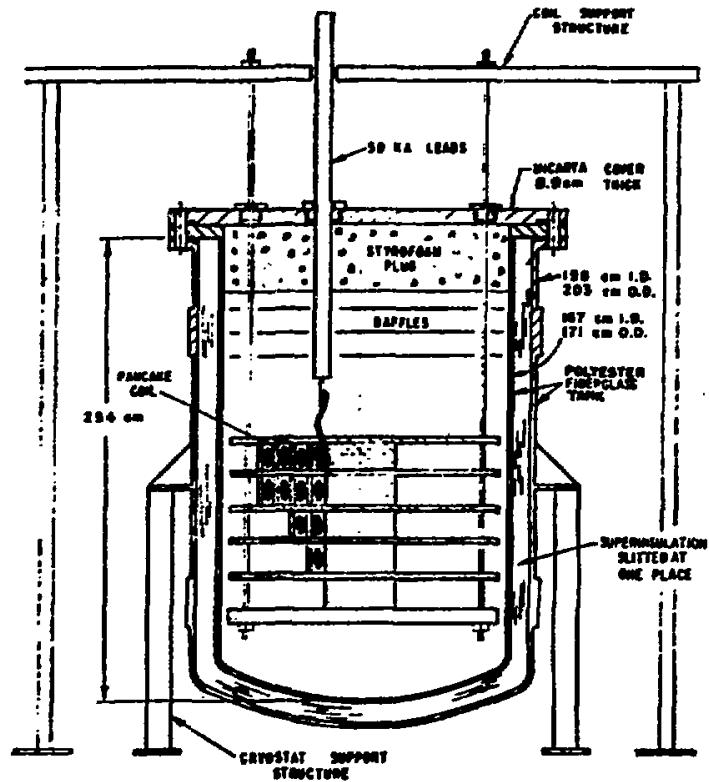

Fig. 3. Set-Up of the Non-Hetalle Cryostat for the Text of the Pancake Co1ls

A non-aetallic cryoutat for the test of the pancake colls is developed. The cryoutat conststs of two figerglass reinforced polyester tanks (Fig. 2) and 100 luyers of auperinsulation between then. Overall dimensions and support structures of the cryostat are show in FIg. 3. The cryostat support atructure is incorporated into the outer tank so that the cryostat could be supported in an upright position. To reduce the aechanical load to the top cover of the cryostat, an exteranl support structure 1s introduced to sustain the pancake colls. Heat leak of the eryostat, eatiated from the cryostat, developed in the pat for the $1.5 \mathrm{MJ}$ coll, is approximately o H (11 LHe/hr).

Table 1. Pancake Coll Parameters

Stored energy (MJ)

Ceatral field (T)

Critical current (kA)

Inductance (nil)

$\cos 2$ is (ca)

$\operatorname{cot1}$ OD (ca)

Coll axial length (cm)

Mumber of prncakes

Total number of turns

Coll current density $\left(\mathrm{A} / \mathrm{cm}^{2}\right)$

$\mathrm{Cu} / \mathrm{SC}$

Heat flux when nornal (H/en ${ }^{2}$ )

Hysteres 1: los: (KJ/ejcie)

Eddy current loes at 9 Tfo (kth)

Heat flux due to ac loses at $9 \mathrm{~T} / \mathrm{s}\left(\mathrm{W} / \mathrm{cm}^{2}\right)$

AC losses/atored energy $(x)$

\section{References}

1. S. H. Kin, S.-T. Wang, H. F. Praeg, C. I. Krieger, and $H$. Wiebert, IEEE Trans. Mngnetics, MG-15. 840 (1979).

2. S. H. Kin, S.-T. Wang and $X$. Liebere, "Operaclng Characteristics of the $1.5 \mathrm{~kJ}$ Pulsed Superconducting Col1," Mivances in Gyogeaic Enelneerine. (Plenum Press, New York) to be published.

3. S.-T. Wang and S. H. Kim, "Argonne Macional Laboracory Superconducting Pulsed Col1 Progran," International Symosilu on Superconductive Energy Storage, Osake, Japan, Oct. 8-9, 1979. 


\section{GENERAL MHAS-FREQUETCY SHIFTING IN THE THREE-PHASE INDUCTOR-CONVERTER DELDGE"}

M. Thean1, R. L. Kustom. R. E. Fuja, T. J. Barnardt Argonne National Laboratory

Argonne, IL 60439

\section{Abuerect}

A fundweatal wethod of shifting phese frequency in the inductor-converter bridge (ICB) for the purpose of controlling the power in teal the la prasented, Tranglane swicching sequences needer hi: inplement phase-irequency shifting can be devalows by the uce of chis wethod and the other five system coserraints. Two of the cogetraints that have been expresed in equation fort so far are presented. Finally, an alcernative alsorithe for computing the frequency shifting transient sequances in real tine is suggerted.

\section{Introduct 100}

The ICB is a solld state dc-ac-de sonverter systen for reversible mergy transfar batween two high $Q$ inductors, F1B. 1. The converter SCR's are naturally conautated by a set of $y$-connected capacitors on the ac lines of the circult. Tha circule is dealgned so that in every convertar cycle, a vary sell fraction of the aegnetic energy is seored in the capacicors and then tranuferred. The Inherenc efficlency and real tioe control of power in eicher d1rection ake these c1rcults a epacially autcable porer aupply for pulaed superconductive agnets. Two such applications are the superconductive equilibrium field colls of the projected Toknak fuston power reactore and auperconduccive angeta aeeded in the fucure particle accelerators. In such syaten, the load constitutes one of the ICE co114, the other co11 being a storage superconductive co11. Stored energy is supplied to an retrieved from tîn load.

The detalle of operation of the ICB any be found In references $I$ and 2 . It has been shown alytical$1 y^{3,4}$ that the transterted power in the ICA eircuit is coutrolled by two paranters of the storage and loed convertars: tha1r relative oparating phece and thetr operating frequacy. Equation (I) ahowe the inntentaneous average pourer delivered to the load.

$$
\begin{aligned}
& \langle p\rangle-\frac{\sum}{a} \frac{12<1 s^{2}\langle 1\rangle}{n^{3} \pi^{2} \omega C}\left[1-(-1)^{n}\right] \sin ^{2} \frac{n \pi}{3} \sin n \\
& \text { A } k\left\langle 1_{S}\right\rangle\left\langle 1_{L}\right\rangle
\end{aligned}
$$

where $n$ - Pourtar harwonic auber of the phese currate

C - capecitence par phasa

and the othor variables are defined in the appendix.

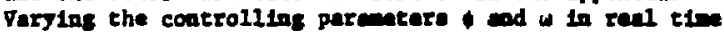
requires foducins careful trantent artechinge on the converters is descrfbed in thits paper.

\section{Irengleat sudtehine in the ICs}

$A$ briose transient errteching 10 defined a a terporery Incrence or decrenes of the time Intervale betweed SCR ffrtegs. Swtching tranolente ay be laduced

thork supported by the U.S. Departaneat of Eaersy. thiso et the Datversity of Wieconte, Madieon, WI. tAleo at Oaklesed Un1were1ty, Docheter, MI. to concrol che operating phase, frequency, or both. A successful transient suitching should satisfy six constralnes inposed by the ICB clrcult and the controlling systeas:

1. neet the oparating phase deanad,

2. seet the frequency demand,

3. thould not cause phase overvoltages,

4. hould not cause SCR comucation fallure,

5 . should not cause phase voltage unbalance,

6. should be as fast as posuibla.

\section{Phase Shifting Irensienta}

The relative phase of the two converters is altered by delaylag or advanciag the relative witching event: of the two converters. The oluplese way to induce a phase shifting transient and wet constraint 5 above is a three-atep tranaient, Fig. 2. The three uteps are a characteristic of the thrae-phase ICs. Conscratacs 3 and 4 can nacessitate the phase ahife to be Induced by wore shan the atnimu three etepa. In these cases, a nulciscap transient 1e produced by superposition of soveral three-step fundanental cransieats in tanden.

In general, in n-acep traneicat witching sequence con be conetructed from the sul of a witch1ng sequeace components.5 The eequence eny be defined as tollows:

$$
\begin{aligned}
& {\left[s^{(n)}\right]^{\top} \& \quad\left[\Delta t_{i}^{(n)} \Delta t_{2}^{(n)} d t_{3}^{(n)} \Delta t_{1}^{(n)} \ldots \Delta t_{n}^{(n)}\right]} \\
& {\left[s_{1}^{(n)}\right]^{\top} \& \Delta t_{0}\left[\begin{array}{llllll}
1 & 1 & 1 & 1 & \ldots & 1
\end{array}\right]} \\
& {\left[s_{2}^{(n)}\right]^{\top} \otimes \Delta c_{2}\left[\begin{array}{llllll}
1 & 0 & 1 & 1 & \ldots & 1
\end{array}\right]} \\
& {\left[s_{3}{ }^{(n)}\right]^{\top} \& \Delta t_{3}\left[\begin{array}{llllll}
1 & -i & 1 & 0 & \ldots & 0
\end{array}\right]} \\
& {\left[S_{4}^{(n)}\right]^{\top} \Delta \Delta_{s}\left[\begin{array}{lllllll}
0 & 1 & -1 & 1 & \ldots & 0
\end{array}\right]} \\
& \text { : } \\
& {\left[E_{n}{ }^{(n)}\right]^{\top} \Delta t_{n}\left[\begin{array}{llllll}
0 & 0 & \cdots & 1 & -1 & 1
\end{array}\right]}
\end{aligned}
$$

where the variables are defted in the appendix. Based on Eq. (2), a geoeral n-step trenetent errtehiag sequace vill be

$$
s^{(n)}-s_{1}^{(n)}+s_{2}^{(n)}+\ldots+s_{n}^{(n)}
$$

or

$$
\left[\begin{array}{c}
\Delta t_{1}{ }^{(n)} \\
\Delta t_{2}{ }^{(n)} \\
\Delta t_{3}{ }^{(n)} \\
\Delta t_{4}{ }^{(n)} \\
\vdots \\
\Delta t_{n}{ }^{(n)}
\end{array}\right]=\left[\begin{array}{l}
\Delta t_{0}+\Delta t_{2}+\Delta t_{3}+0+0+\ldots+0 \\
\Delta t_{0}+0-\Delta t_{3}+\Delta t_{4}+0+\ldots+0 \\
\Delta t_{0}+\Delta t_{2}+\Delta t_{3}-\Delta t_{4}+\Delta t_{5}+0+0 \\
\Delta t_{0}+\Delta t_{2}+\Delta t_{3}+\Delta t_{4}-\Delta t_{5}+\Delta t_{6}+0 \ldots+0 \\
0+0+\ldots \\
0 \\
0 t_{n-2}=\Delta t_{n-1}+\Delta t_{n}
\end{array}\right]
$$


$-\left[\begin{array}{cccccccc}1 & 1 & 1 & 0 & \ldots & & & 0 \\ 1 & 0 & -1 & 1 & 0 & \ldots & & 0 \\ 1 & 1 & 1 & -1 & 1 & 0 & \ldots & 0 \\ \vdots & 1 & 0 & 1 & -1 & 1 & 0 \ldots & 0 \\ \vdots & & & & & & & 0 \\ 1 & 1 & 0 & \ldots & 0 & 1 & -1 & 1\end{array}\right]\left[\begin{array}{c}\Delta t_{0} \\ \Delta z_{2} \\ \Delta t_{3} \\ \Delta t_{2} \\ \vdots \\ \Delta t_{2}\end{array}\right]$

- $\left[A_{3}\right][\mathrm{ct}]$

The antrix $\left[\mathrm{A}_{3}\right]$ Io called the characteristic tranolent Ticrix of the three-phase ICB. Ocher witiphase ICB circtien vil have chelr oun unique characteristic tranelent atrix.

\section{Frequancy Shiftin Trandents}

The frequency of operation of the ICD circult is aitered by increaning or decreaeins the tim intervale between the SCR firings on both converters. The atpleat way of changing frequeacy, whlle obearving constraint 5, is a three-utep treacient. F1s. 3. Hote that the fundareatal transieat for frequeacy ohifting. $S_{2}(n)$, is different froc that for phase ahiftion, $s_{3}(a)$. It can be seen, from Inopection of $\mathrm{PI}$. 3 , that - pure frequency shift vill alter the ICA oparacting phase. To correct for th1s, a three-step compenset ins phese shift wy be auperisposed of the frequercy shifting transient. The resulting trasient sequence, fro Eq. (3) vill be

$$
s^{(3)}-s_{1}^{(3)}+s_{2}^{(3)}+s_{3}^{(3)} .
$$

If wore translent steps are neceseary to set the coactraints, the geateral zqe. (2). (3) and (4) are uned.

It 10 poestble to control both phase and frequency in one trabalent sequence. A phase-frequency ablftins trenelent enqueace is produced exnctly as a frequency shifting sequence. Horever, the phese copenetet sequence is edjueted to produce acy phee rather then anintein the oristan phese.

\section{The Coontraint Equetson:}

The fanteat way of comptin the intervels of phese-frequacy endfteins traneleat, in real tim, is to

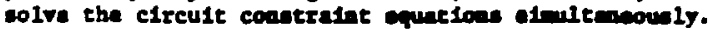
For exaple, coastratnts 1 ad 2 an be formuleted, respectively, as follow:

$$
\begin{aligned}
\sum_{1=1}^{n}\left[\Delta t_{15}(n)-\Delta t_{1 I}(n)\right] & -\Delta[\Delta t)_{1}=\frac{t_{1}-0}{60^{\circ}}\left(\Delta t_{1}\right) \\
& -\Delta t_{1}-\frac{\Delta t_{1}}{\Delta t_{0}}\left(\Delta t \phi_{0}\right) \\
\Delta t_{2}-\Delta t_{1}-\Delta t_{0} & =\frac{1}{6}\left(\tau_{1}-\tau_{0}\right)-\frac{I}{3}\left(\frac{1}{\omega_{1}}-\frac{1}{\omega_{0}}\right)(7)
\end{aligned}
$$

Conctraine $S$ is repreanted by zq. (4). Coastralnte 3 , 4, and 6 ung atiliarly be tremetated to equation form.

\section{d Frequency Shifting Algorlthe}

The next best way to the analytical calculation of the transient intervals is chooding the intervals in a reasoneble way and then testing them againet the c1rcult constralats. The following is an exmple algorithn for computing the intervals of a frequency sh1fting tranalent.

$$
\Delta \tau_{1}^{(n)}-\frac{\Delta t t_{0}}{\Delta t_{0}}\left[\Delta t_{1-1}^{(n-1)}-\Delta t_{1}^{(n-1)}\right]+\Delta t_{1}^{(n-1)}
$$

Th1s Is an Iterative formula that compitea the interval. of an n-step transient from those of an (n-1)-step trmsient. The iteration starts from the fundanental or three-step transient.

$$
\Delta c_{1}{ }^{(3)}-\frac{\Delta t_{0}}{\Delta t_{0}}\left(\Delta t_{0}-\Delta t_{1}\right)+\Delta t_{1}
$$

This algor 1thm produces smoother transition frov one frequency to the next as the number of transient steps are lncreased. Thus, the chences of weting constrainte 3 and 4 are improved. The comutetion thrashold curves (constraint 4) of the three-step transient have been computed by a digital computer and wown in F1ga. 4 and 5 .

\section{Conclusion}

The Instantaneous equation of the load average power in the ICB c1rcult shows that thil syoten var1able can be controlled by the fraquency and ralactve phese of the converters. Real ciec control of phese Erequency requires inducing trensient swicching eequences on the converters. These sequences aut couply with the otx constraints for succeseful and optinal operation of the syater.

Th1e peper presented a fundementel technique for shifting phese frequency while ealntalning phese voltape baleace. The techalque praduces $(n-1)$ unknown tine Incremate where $n$ is the number of transient incervale. These unlmows are to be calculated frou the othar constralnt equat 1ons, two of wh1ch are presented.

As en elternat 1ve, athod of "plcktng" reaconable transient intervals and then chacking the against the constratnts is subsected.

\section{Referencee}

1. R. L. Tusto et al. "The Dea of Multiphase Inductor-Couverter Bridges as Actively Controlled Pour Suppliee for Tokmit Co1le," Argonne National Laboratory Raport ANL/FPP/TH-78 (Apr11 11, 1977).

2. W. A. Peterson ec el.. "Suparconductive InductorConverter Vaits for Pulend Power Losde," Proceed1nge of the International Conference on Energy Storaye, Compreasion and Switching, Aeti-Torino, Italy (lioveaber 1974).

3. M. thren1, R. L. Kuetom, "Apelyse of the Mult1phese Inductor-Convertar Bridge," Argonne Hac1onal Laboratory Report MN/FPP/MH-114 (Auguse 1978).

4. H. tham1, R. L. Kuston, "Squara Function Analyule of the Inductor-Converter Bridge," Argonne Hational Laboratory Report NL/FPP/MH-118 (Wireh 1979).

5. M. Thean1, R. L. Turos, et al., "Goneral PheseFraquency Shitting in the Three-Phase InductorCoavertar Briden," Argonne detional Laboratory Report NL/FPe/IM (Auguet 1979). 
dppend1x

\section{Definicion of Syebol:}

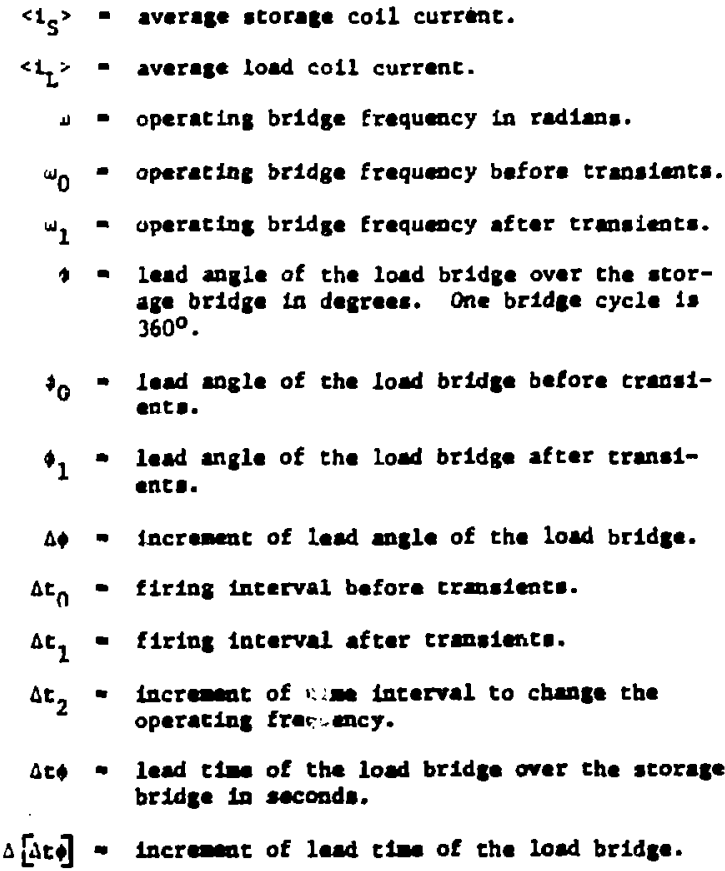
age bridge in degrees. One bridge cycle is $360^{\circ}$.

$t_{G}$ - lead angle of the load bridge before transtenta.

$1_{1}$ - lead angle of the load bridge after transienta.

Ap - Incrament of lead angle of the loud bridge.

$\Delta t_{n}$ - flring incerval before crmelente.

$\Delta t_{1}$ - f1ring 1nterval after cransienca.

$\Delta t_{2}$ - Incremat of $:$ ine incerval to chenge the operac1n: Erar-ency.

Dt - lead tine of the load bridge over the storage bridge in seconds.

$\Delta[\Delta t \cdot]$ - Increnat of lesd tine of the load bridge.

sto - lead tim of the load bridge before transenes.

$\Delta f_{1}$ - lead tiae of the load bridge after trensientes.

$\Delta t_{15}{ }^{(n)}-1$ th incerval of an n-atep tranelent on the storage bridge.

$\Delta t_{11}(n)-1$ th interval of an n-atep transient on the load bridge.

$\Delta t_{1}$ - Increment of time interval correuponding to the 1 th sequence component.

[At] - vector of tim increments.

$s^{(n)}$ - suquence vector of the intervals of an $n-$ step treneient sutching.

$S_{1}{ }^{(\Omega)}$ - 1 th sequence component of an n-step tran olent.

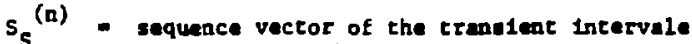
on the storage bridge.

$s_{f}{ }^{(n)}$ - equence vector of the traneient intervale on the load bridte.

$\left[A_{f \downarrow}\right]$ - characterintic transient eatrix of a $f-$

I - the period of one bridge cycle in seconde.

$T_{0}$ - bridge period before ermensats.

$T_{1}$ - bridge period after troulente.

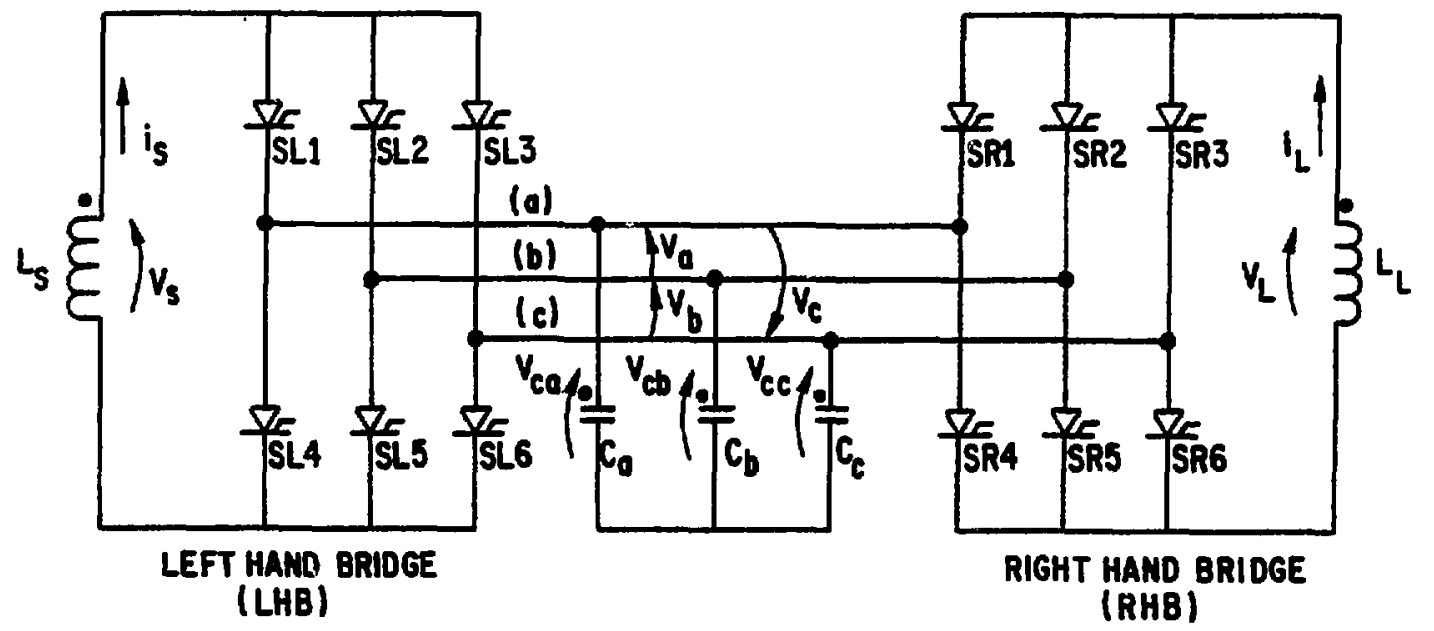

SL1 SL5, SLI SL6, SL2 SL6, SL2 SL6,

SL3 SL4, SL3 SL5, SL1 SL5, ...

Fig. 1. Circuit Diagran for the 3-Capacitor Model IC Bridge. 


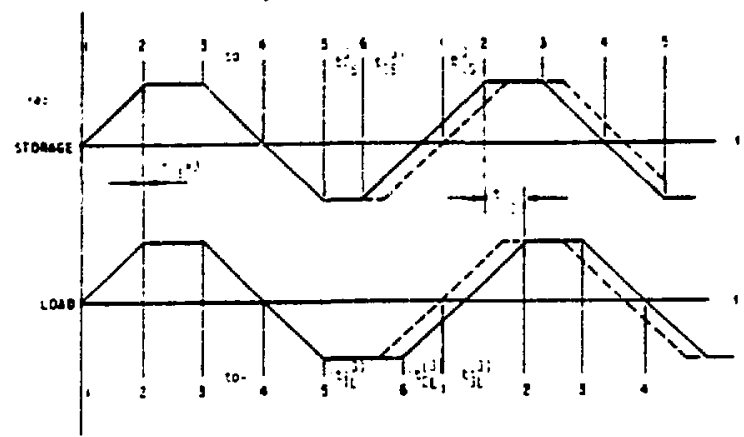

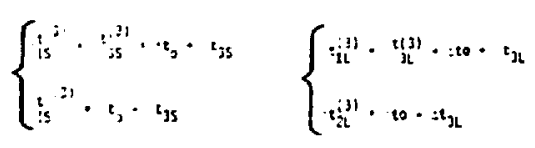

$t_{2 S}>s t_{3 L} 0$

F1g. 2. Phase voltage waveforas of a three-step phase ohtft.

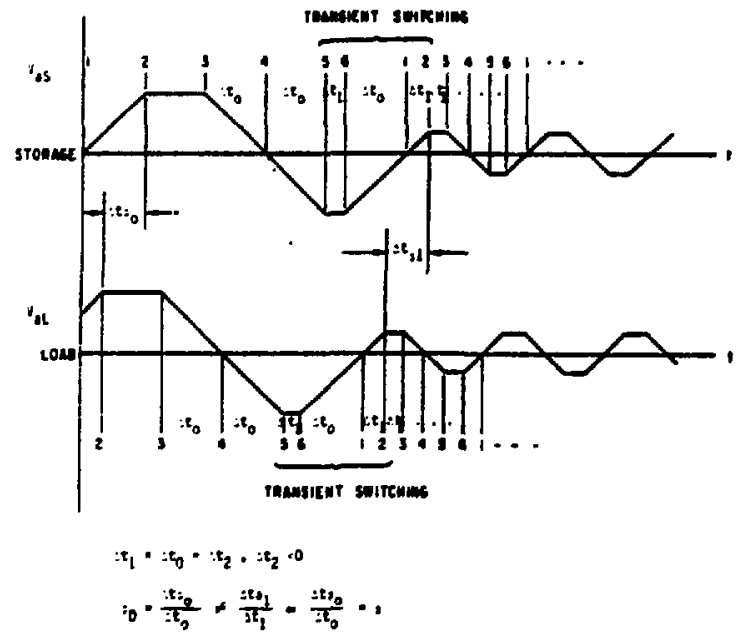

E18. 3. Phese voltage wavefores of a three-atep frequacs ahift.

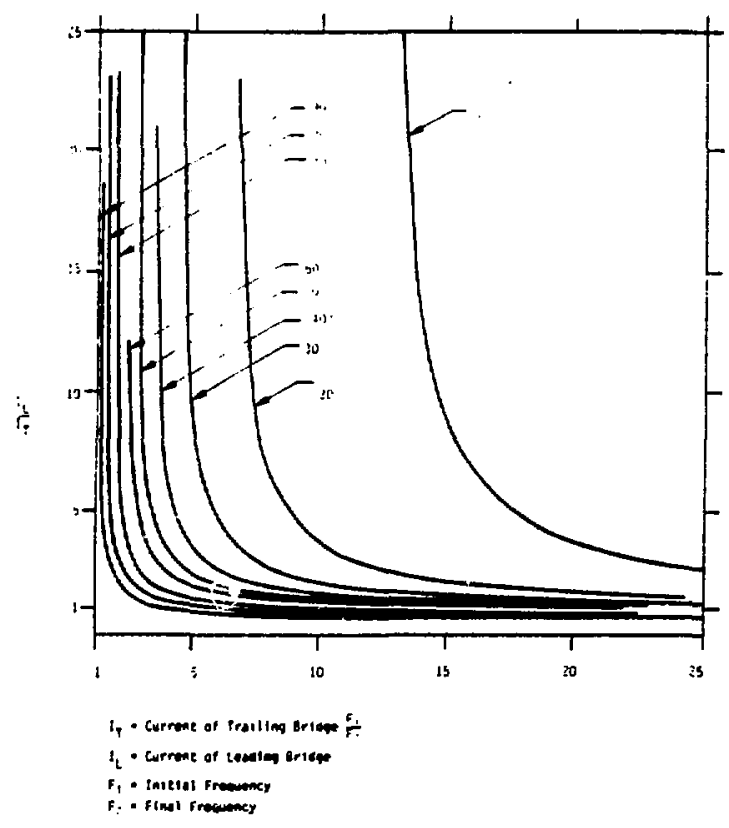

F1g. 4.

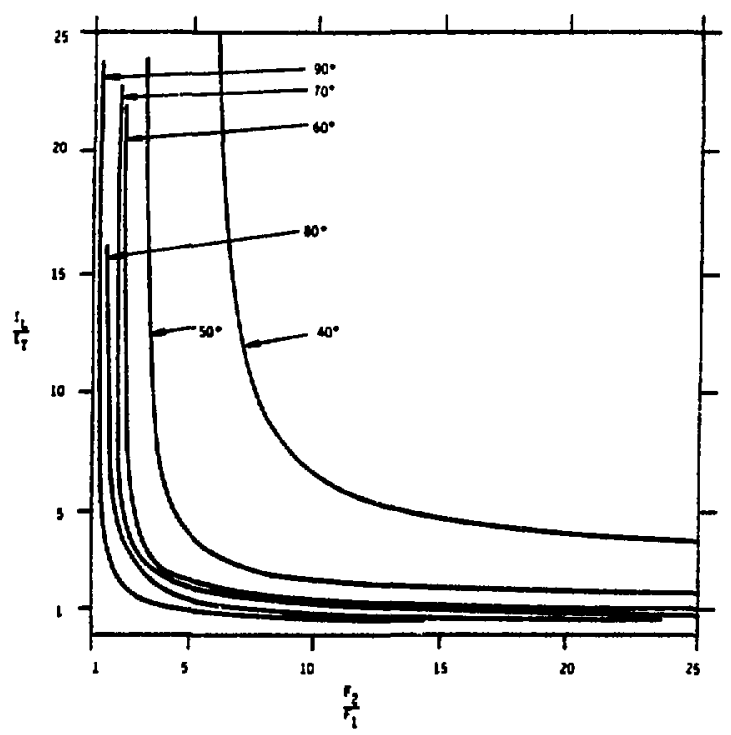

F18. 5. 


\section{Incernal:}
M. Abdou
R. Arnold
C. Baker
C. Boley
A. Bolon
J. Brooks
R. Burke
F. Cafasso
R. Clemmer
J. dePaz
D. Ehst
K. Evans
P. Finn
R. Fuja
Y. Gohar
J. Jung
W. Kann
S. H. Kim
Y-K. Kim
R. Kustom
V. Maroni
W. E. Massey
R. Martin
R. Mattas
B. Misra
J. Norem
E. G. Pewitt

W. Prace

J. Roberts

D. L. Smith

R. P. Smith

H. Stevens

L. Turner

S-T. Wang

R. Weeks

FP Program (33)

A. 8. Krisciunas ANL Contract File ANL Libraries (5) TIS Files (6)

\section{External:}

DOE-TIC, for distribution per UC-20 (117)

Manager, Chicago Operations and Regional Office, DOE

Chief, Office of Patent Counsel, DOE-CORO

Fresident, Argonne Universities Association

Applied Physics Division Review Committee:

P. W. Dickson, Jr., Westinghouse Electric Corp.

R. L. Hellens, Combustion Engineering, Inc.

K. D. Lathrop, Los Alamos Scientific Lab.

W. B. Loewenstein, Electric Power Research Inst.

R. F. Redmond, Ohio State U.

R. Sher, Stanford U.

D. B. Wehmeyer, Detroit Edison Co.

N. Amherd, Electric Power Research Inst.

D. J. Anthony, General Electric Co., Schenectady

R. E. Aronstein, Bechtel National, Inc., San Francisco

S. Baron, Burns \& Roe, Inc., Oradell, N. J.

J. Baublitz, U. S. Department of Energy

Bibliothek, Max-Planck-Institute fur Plasmaphysik, Garching, West Germany

Bibliotheque, Service du Confinement des Plasmas, CEA, Seine, France

C. J. Blattner, McDonnell Douglas Astronautics Co., St. Louis

R. Botwin, Grumman Aerospace Corp., Bethpage, N. Y.

R. Bussard, Energy Resource Group, Inc., Arlington, Va.

G. Carlson, Lawrence Livermore Lab.

G. Casini, Commission of the European Community, Ispra, Italy

J. Cecchi, Princeton U.

C.-H. Chen, Chinese Academy of Sciences, Peking, China

D. Cohn, MIT Plasmn Fusion Center, Cambridge

R. Conn, U. California, Los Angeles

J. Crocker, EG\&G Idaho, Inc., Idaho Falls

J. Davis, MeDonnell Dougles Astronautics Co._East, St. Louis

S. Dean, Science Applications, Inc., McLean, Va.

D. DeFreece, McDonnell Douglas Astronautics Co.-East, St. Louis

D. Dingee, Battelle-Pacific Northwest Lab.

J. W. Feldman, General Electric Co., Sunnyvale 
C. Flanagan, Westinghouse Electric Corp., Pittsburch

H. K. Forsen, Exxon Nuclear Co., Inc., Bellevue, Wash.

T. K. Fowler, Lawrence Livermore Lab.

H. Furth, Princeton U.

J. Hancox, Culham Laboratory, Abingdon, Eneland

S. D. Harkness, Westinghouse Electric Corp., West Mifflin, Pa.

G. Head, U. S. Department of Energy

I. G. Hedrick, Grumman Aerospace, Bethpage, N. Y.

J. Holmes, Hanford Engineering Development Lab.

R. Huse, Public Service Electric and Gas Co., Newark, N. J.

D. Jassby, Princeton U.

T. Kammash, U. Michigan

J. Kokoszenski, The Raiph M. Parsons Company, Pasadena

R. A. Krakowski, Los Alamos Scientific Lab.

D. Kummer, McDonnell Douglas Astronautics Co.-East, St. Louis

T. Latham, United Technologies Research Center, East Hartford

Librarian, Culham Laboratory, Abingdon, England

Library, FOM-Institut voor Plasma-Fysica, Rijnuhuizen, The Netherlands

Library, Centre de Recherches en Physique des Plasma, Lausanne, Switzerland

L. M. Lidsky, MIT Plasma Fusion Center, Cambridge

F. J. Loeffler, Purdue U.

M. J. Lubin, U. Rochester

D. G. McAlees, Exxon Nuclear Corp., Bellevue, Wash.

R. W. Moir, Lawrence Livermore Lab.

D. B. Montgomery, MIT Plasma Fusion Center, Cambridge, Mass.

S. Naymark, Nuclear Services Corp., Campbell, Calif.

D. Nelson, U. S. Department of Energy

R. Ng, U. S. Department of Energy

D. J. Paul, Electric Power Research Inst.

J. Powell, Brookhaven National Lab.

P. J. Reardon, Princeton U.

F. Ribe, U. Washington

A. Robson, Naval Research Lab.

P. Rose, Mathematical Sciences Northwest, Inc., Bellevue, Wash.

J. L. Scott, Oak Ridge National Lab.

R. Scott, Electric Power Research Inst.

T. Shannon, Oak Ridge National Lab.

Z. Shapiro, Westinghouse Electric Corp., Pittsburgh

W. M. Stacey, Jr., Georgia Inst. Technology

D. Steiner, Oak Ridge National Lab.

C. E. Taylor, Lawrence Livermore Lab.

F. H. Tenney, Princeton U.

Thermonuclear Library, Japan Atomic Energy Research Institute, Tokai, Japan

C. Trachsel, McDonnell Douglas Astronautics Co., St. Louis

N. A. Uckan, Oak Ridge National Lab.

L. J. Wittenberg, Monsanto Research Corp., Miamisburg, O.

K. Zwilsky, U. S. Department of Energy 